I N T ER N ATIONAL MONETARY FUND

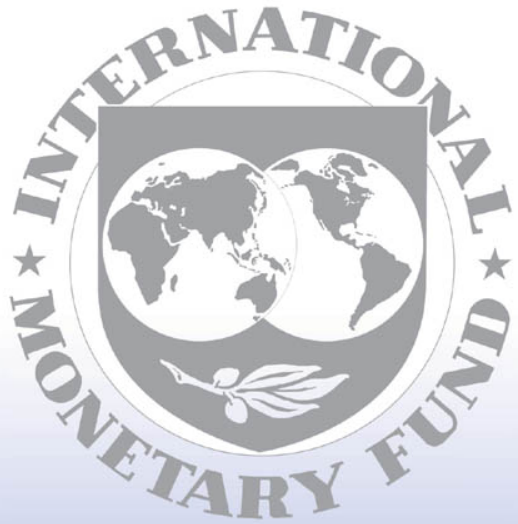

Staff

Country

Reports 


\section{Sweden: Financial Sector Assessment Program-Detailed Assessment of Observance of Standards and Codes}

This Detailed Assessment of Observance of Standards and Codes on Sweden was prepared by a staff team of the International Monetary Fund as background documentation for the periodic consultation with the member country. It is based on the information available at the time it was completed on July 2002. The views expressed in this document are those of the staff team and do not necessarily reflect the views of the government of Sweden or the Executive Board of the IMF.

The policy of publication of staff reports and other documents by the IMF allows for the deletion of market-sensitive information.

Copies of this report are available to the public from

International Monetary Fund • Publication Services

700 19th Street, N.W. • Washington, D.C. 20431

Telephone: (202) 6237430 • Telefax: (202) 6237201

E-mail: publications@imf.org • Internet: http://www.imf.org

\section{International Monetary Fund \\ Washington, D.C.}


CONFIDENTIAL

For Restricted Use Only (Not for use by third parties)

\section{Financial Sector Assessment Program}

\section{FSAP: Detailed Assessment of Observance of Standards and Codes}

\section{SWEDEN}

JULY 2002 
This report is classified as CONFIDENTIAL under applicable IMF administrative orders, policies and guidelines. The report, in whole or in part or summaries thereof, may not be disclosed or released to any unauthorized party or quoted in other documents. 
I. Observance of Basel Core Principles for Effective Banking Supervision ... $\frac{5}{5}$

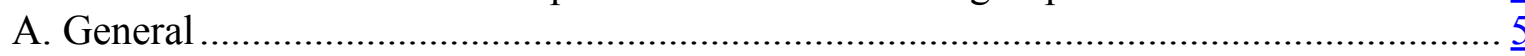

B. Information and Methodology Used for Assessment............................................... $\frac{5}{5}$

C. Institutional and Macro Prudential Setting, Market Structure Overview......................... $\frac{5}{5}$

D. General Preconditions for Effective Banking Supervision ............................................ 7

E. Recommended action plan and authorities' response to the assessment....................... 49

Recommended action plan ................................................................................... $\frac{49}{51}$

F. Authorities' Response to the Assessment.................................................................... $\frac{51}{51}$

II. IAIS Insurance Core Principles............................................................................. $\frac{51}{5}$

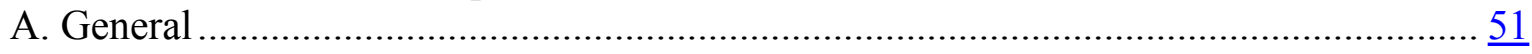

B. Information and Methodology Used for Assessment................................................ $\frac{52}{52}$

C. Institutional and Macroprudential Setting - Overview ……………............................ $\frac{53}{55}$

D. General Preconditions for Effective Insurance Supervision ......................................... $\frac{55}{56}$

E. Principle-by-Principle Assessment........................................................................... $\frac{56}{79}$

F. Recommended Action Plan and Authorities' Response to the Assessment ................... $\frac{79}{81}$

G. Authorities' Response to the Assessment .................................................................. $\frac{81}{16}$

III. IOSCO Objectives and Principles of Securities Regulation ........................................ $\frac{81}{81}$

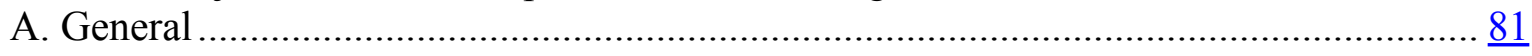

B. Information and methodology used for the assessment ............................................. $\frac{81}{81}$

C. Structure and role of the securities industry ........................................................... $\frac{82}{84}$

D. General Preconditions for Effective Securities Regulation .......................................... $\frac{84}{84}$

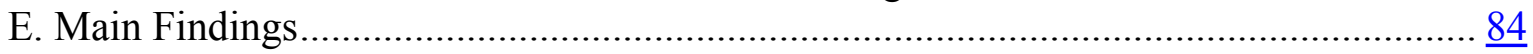

F. Summary of Principle-by-Principle Assessment ………………………………...... $\frac{86}{06}$

G. Recommended Actions and Authorities' Response to the Assessment ....................... $\frac{109}{109}$

Recommended Actions .......................................................................................... $\frac{109}{110}$

H. Authorities' Response …….........................................................................

IV. The CPSS Core Principles .................................................................................

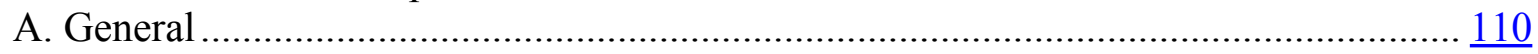

B. Institutional and Market Structure..................................................................... $\frac{112}{116}$

C. Main Findings - Summary ............................................................................... 116

V. Observance of CPSS Core Principles for systematically importing and payment systems

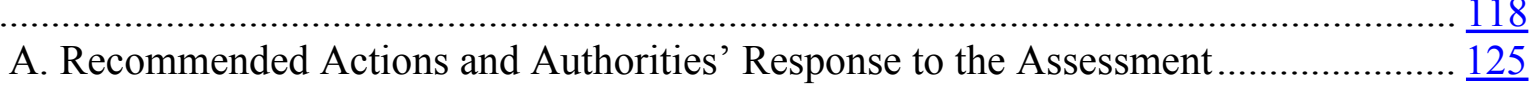

B. Recommended actions and authorities' response to the assessment.......................... $\frac{136}{137}$

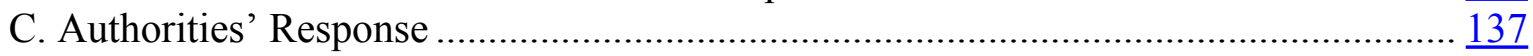

Tables

1. Detailed Assessment of Compliance of the Basel Core Principles....................................... $\underline{8}$

2. Summary Compliance of the Basel Core Principles........................................................ 48

3. Recommended Action Plan to Improve Compliance of the Basel Core Principles ............ $\frac{49}{56}$

4. Detailed Assessment of Observance of the IAIS Insurance Core Principles........................56

5. Summary Observance of IAIS Insurance Core Principles...............................................

6. Recommended Action Plan to Improve Observance of IAIS Insurance Core.................... 
7. Detailed Assessment of Implementation of the IOSCO Objectives and Principles of Securities Regulation .... .$\underline{88}$

8. Summary Implementation of the IOSCO Objectives and Principles of Securities Regulation..... $\underline{108}$

9. Recommended Plan of Actions to Improve Observance of the IOSCO Objectives..........109

10. Summary observance of CPSS Core Principles and Central Bank ................................124

11. Recommended actions to improve observance of CPSS Core Principles and.................125

12. Summary observance of CPSS/IOSCO Recommendation for securities .......................135

13. Recommended actions to improve observance of CPSS/IOSCO ................................136 


\section{Observance of Basel Core Principles for Effective Banking Supervision}

\section{A. General}

1. The assessment of compliance of the Basel Core Principles for Effective Banking Supervision in the supervisory work of the Swedish Financial Supervisory Authority (Finansinspektionen; "FI") was performed by Allan D. Fink of the Federal Reserve Bank of Chicago and Mr. Tuomo Malin of the Finnish Financial Supervision Authority.

\section{B. Information and Methodology Used for Assessment}

2. The assessment was performed on the basis of the Methodology of the Basel Core Principles and the Draft Methodology Document prepared by the IMF and World Bank titled Enhancing the Global Effort Against Money Laundering. The Swedish Financial Supervision Authority submitted a self-assessment of the Core Principles prior to the mission. Additionally, on request, the authority produced a self-assessment on the draft on money laundering. The main sources for the assessment were the laws and supervisory regulations and guidelines concerning credit institutions. Law texts were obtained on the web site of the Swedish Parliament, the English versions on the site of the Bankers' Association. The supervisor's regulations were, for the most part, available only in Swedish. Additionally, the assessors received relevant material from the central bank. Meetings took place with representatives from the main commercial banks.

3. The assessors did not encounter any major barriers in making their assessment despite the scarcity of documents available in English.

\section{Institutional and Macro Prudential Setting, Market Structure Overview}

4. In Sweden there are three different types of banks: commercial banks, i.e., limited liability banking companies, savings banks and a few cooperative banks. All these types of banks are entitled to engage in all types of banking activity. The number of banks has declined sharply as a result of mergers, a tendency that has been most marked among the savings banks. From some 450 savings banks of the 1950s, the number had decreased to 85 by the late 1990s. Since the middle of the 1980s, however, numerous new banks have been established in Sweden. The market structure can be described as two-tiered with five large banks (Handelsbanken, Skandinaviska Enskilda Banken, Nordbanken and Förenings Sparbanken as well as the Swedish subsidiary of a major Danish bank) having a combined market share of about 75-85 percent; the residual market is shared among around 100 smaller banks. The home market for Swedish banks has to a greater extent been seen to embrace not only the traditional Nordic area but the whole region surrounding the Baltic Sea.

5. The four major Swedish banks are very broadly held. The largest owners are the Swedish government (less than 20 percent in Nordea), the Wallenberg-led investment company Investor (some 10 percent in SEB), the employees' pension fund (some 10 percent in Svenska Handelsbanken), and the former savings banks foundations (some 20 percent in Swedbank, which was earlier a savings bank, which merged with a cooperative bank and 
became a commercial bank). Approximately one third of bank shares are held by nonSwedes. The medium and small-sized banks are generally held by one dominating owner, which in turn may have a widely spread ownership, such as Skandia. All savings banks are non-profit organizations and they are held by foundations.

6. The Swedish Financial Supervisory Authority is a government authority responsible to the MoF. It exercises supervision over banks, credit market companies, and additionally e.g., insurance companies, insurance brokers and securities companies. The role of FI is to ensure that statutory regulations are complied with, that secure and sound practices are applied and that confidence is maintained in the stability and functionality of the financial markets. The cost of FI's activities is defrayed out of charges levied on banks and other supervised entities. The FI's annual budget is decided by the government. One of FI's primary tasks is to promote satisfactory consumer protection; additionally the National Board for Consumer Complaints, a government authority, has as its role to offer an alternative to legal action in court in connection with disputes between consumers and business firms. The Board has a separate banking to consider disputes between banks or other credit institutions and their customers.

7. The Central Bank Act assigns to the Riksbank the responsibility to ensure a stable and efficient payment system. It also assigns to the Riksbank the responsibility for monetary and exchange rate policy (including the management of the gold and currency reserves), as well as managing the issue of notes and coins, providing a clearing function for banks as well as accepting deposits from banks and granting them loans. The Central Bank also functions as lender of last resort providing financial aid to banks experiencing liquidity problems.

8. The legal framework for the banking sector is provided in the Banking Business Act that contains provisions regulating the business a bank may engage in e.g., the granting of credit. The act also contains essential provisions concerning the tasks of FI in the supervision of banks. Commercial banks are also subject to the Companies Act. There are special acts for savings banks and cooperative banks (so-called members banks). The Act on Capital Adequacy and Large Exposures for Credit Institutions and Securities Companies contains rules on how to calculate the capital base and capital adequacy to cover credit risks and market risks. The act also includes provisions stipulating limits for the exposure of credit institutions in relation to their clients, and rules concerning consolidated supervision. The Act on Financial Operations has provisions on licenses for and the activities of credit market companies, i.e., limited liability companies which have received a license from FI to engage in financing activities, such as credit mortgage institutions and finance companies.

9. The Secrecy Act regulates to what parties and on what conditions FI is obliged to divulge confidential information. Disclosure is mandatory to the parliament and the government. Furthermore, information may be disclosed to the Public Prosecution Authority, the Police force, the Riksbank or to another supervisory authority. The government's annual directive regarding the supervisor's overall objectives and reporting obligations is publicly available. FI operational goals and objectives as presented in its annual plan are also publicly available. The performance of FI relating to its objectives is accounted for in the annual report, that is published and subjected to the review by the Swedish National Audit Office. 
Each year, as a result of its financial stability analysis, FI publishes a report to the government on the stability of the financial system. The Riksbank also publishes its financial stability reports twice annually.

10. FI is an independent government authority without outside interference in its operational functions. The authority has a description of the internal processes and procedures. A government committee's proposition dating back to three years includes plans, as yet unimplemented, to increase the authority's powers. The supervisor cannot, however, with the present level of remuneration compete with the private sector. To improve its capacity to supervise particularly the more complex activities of banks, e.g., related to market risks, the supervisor has to be able to increase its competitiveness as an employer. The renewed capital accord as well as the preponderance of financial conglomerates in the Nordic financial system put in question the adequacy of the supervisor's human resources.

11. The profitability of the largest Swedish banks increased in 2000 . The return on equity ranged between 22 percent and 24 percent, with the exception of the Nordea group (18.6 percent). Credit losses have been on very low level, however they increased to SKR 1.9 billion in 2000. Nonperforming loans went up SKR 4.5 billion to SKR 23.5 billion. The tier 1 capital ratio for commercial banks was 7.9 percent in June 2000, with a slight upward trend from the previous years. Credit growth has been most rapid on the part of households (8.1 percent up from 1999) while total lending to the Swedish public increased by 4.7 percent.

\section{General Preconditions for Effective Banking Supervision}

12. After the disbanding of the Bank Support Authority there have been no standing institutional arrangements for handling banking crises. New arrangements for the resolution of distressed banks have been dealt with in a Committee paper of 1998 where it was proposed that a bank would be placed into public administration where this is necessary in the interests of system stability or where reconstruction is warranted-otherwise the bank is to be declared bankrupt or put into liquidation. The government would be able to take control of a bank's business without taking over ownership of the bank; there would be no option of a compulsory takeover. The new government authority, the Crisis Management Authority, would assume control of the running of the business of a bank by representing all of its shares at general meetings. A government guarantee could be issued in order safeguard that the bank in public administration would meet all commitments arising during the life of the guarantee. At the present time there is no institutional framework for problem bank resolution. In spite of the limitations on the guarantee in the proposal above, the moral hazard aspect can not be discarded, altogether. The government would find itself in a position where it would be effectively regarded as the guarantor of the bank in public administration.

13. The purpose of the Act on Deposit Guarantee Scheme is to improve consumer protection in connection with the public's deposits at banks and certain securities companies by providing a guarantee for deposits of up to SKR 250,000 per customer at each institution. The act contains rules regulating which deposits are covered by the guarantee, when the right to compensation arises, and what fees shall be paid by the institutions covered by the guarantee. Administrative duties lie at the Deposit Guarantee Board. 


\section{Table 1. Detailed Assessment of Compliance of the Basel Core Principles}

\begin{tabular}{|c|c|}
\hline Principle 1. & $\begin{array}{l}\text { Objectives, Autonomy, Powers, and Resources } \\
\text { An effective system of banking supervision will have clear responsibilities and objectives } \\
\text { for each agency involved in the supervision of banks. Each such agency should possess } \\
\text { operational independence and adequate resources. A suitable legal framework for } \\
\text { banking supervision is also necessary, including provisions relating to the authorization } \\
\text { of banking establishments and their ongoing supervision; powers to address compliance } \\
\text { with laws, as well as safety and soundness concerns; and legal protection for supervisors. } \\
\text { Arrangements for sharing information between supervisors and protecting the } \\
\text { confidentiality of such information should be in place. }\end{array}$ \\
\hline Principle 1(1) & $\begin{array}{l}\text { An effective system of banking supervision will have clear responsibilities and objectives } \\
\text { for each agency involved in the supervision of banks. }\end{array}$ \\
\hline Description & 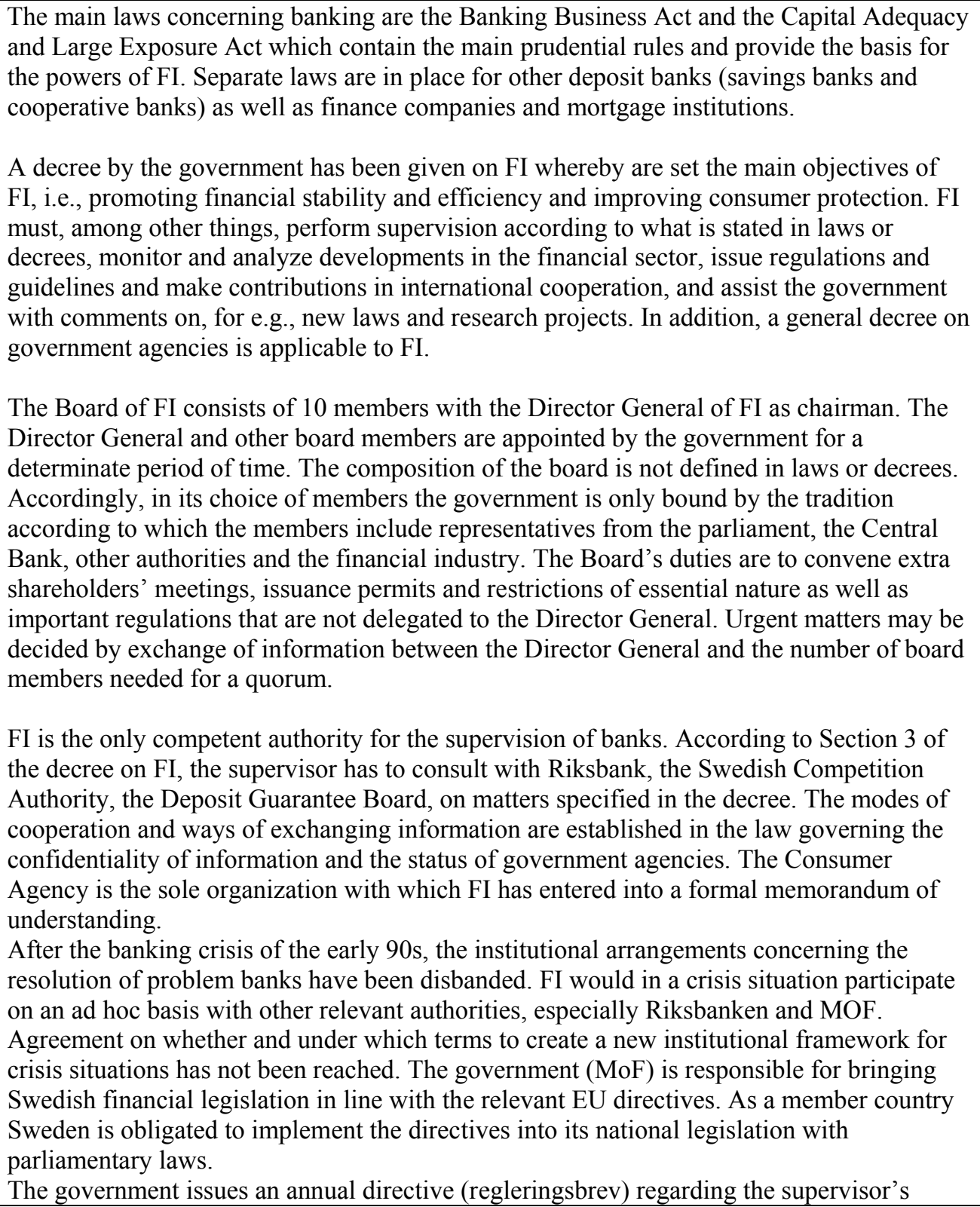 \\
\hline
\end{tabular}




\begin{tabular}{|c|c|}
\hline & $\begin{array}{l}\text { overall objectives with reporting stipulations on the fulfillment of the objectives. The } \\
\text { directions are publicly available (on FI's web site and elsewhere). In order to achieve the } \\
\text { general objectives, FI sets its operational goals and objectives in its annual plan, which is } \\
\text { also publicly available. The goals and objectives are subject to internal review every four } \\
\text { months. } \\
\text { The total performance of FI relating to the over-all objectives is accounted for in its annual } \\
\text { report, which is subject to review by the Swedish National Audit Office. The Director } \\
\text { General of FI appears approximately once a year to make a statement before the } \\
\text { Parliamentary Finance Committee. The supervisory measures that FI takes as against the } \\
\text { banks are made public by the supervisor, subject to rules of confidentiality. } \\
\text { Each year, as a result of its financial stability analysis, FI publishes a report to the } \\
\text { government relating to the stability of the system. FI publishes regularly in cooperation } \\
\text { with Riksbanken and Statistics Sweden official statistics regarding performance in banks } \\
\text { and securities firms. FI also issues a quarterly publication (Sparbarometern) on assets and } \\
\text { liabilities in the household sector. }\end{array}$ \\
\hline Assessment & Compliant \\
\hline Comments & $\begin{array}{l}\text { The laws and regulations on banking activities and their supervision are in place. The } \\
\text { composition of the Board of FI is not regulated in law or other ordinances. The position of } \\
\text { FI in relation to other public agencies in possible crisis situations is not defined in law. }\end{array}$ \\
\hline Principle 1(2) & Each such agency should possess operational independence and adequate resources. \\
\hline Description & 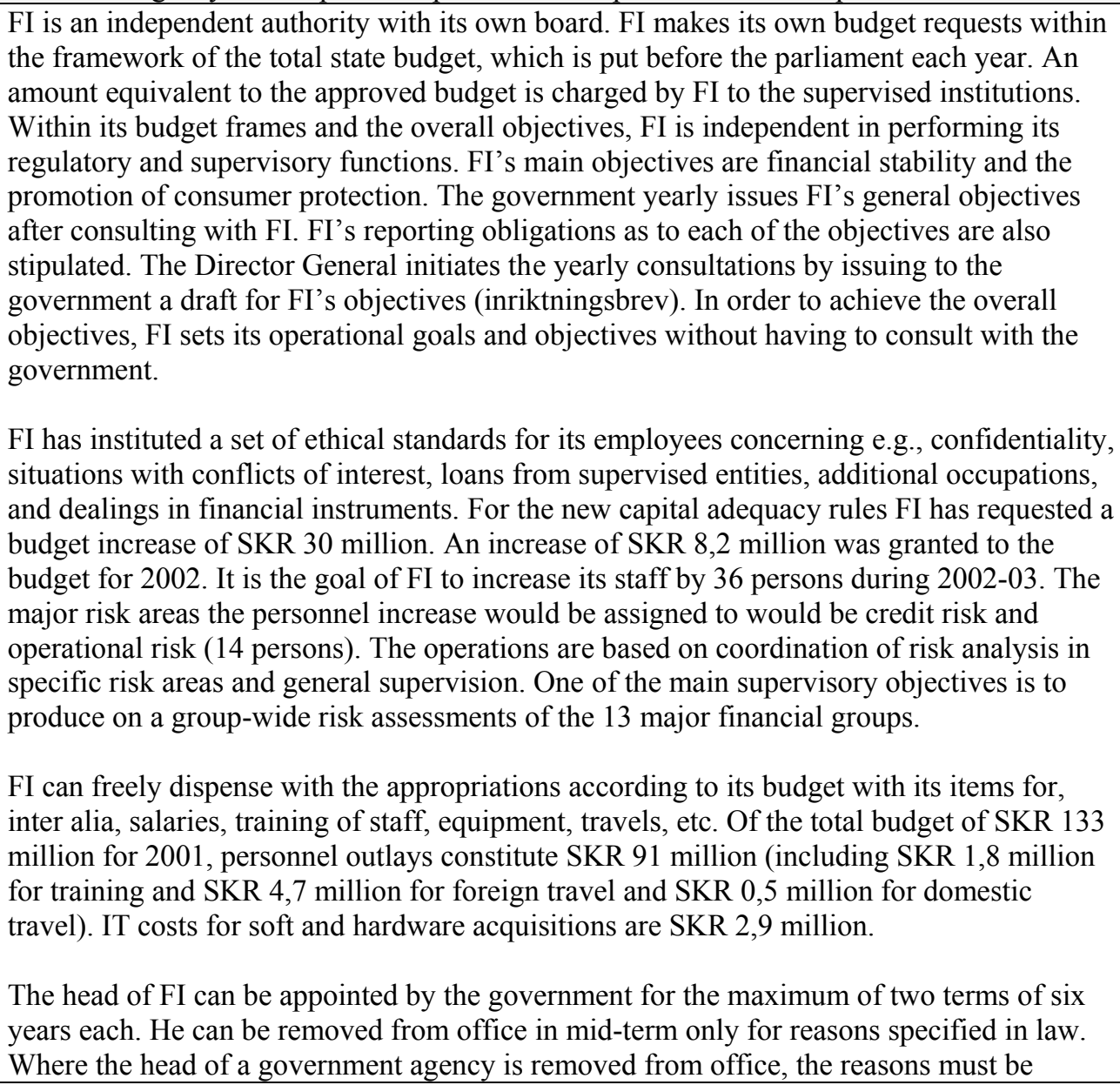 \\
\hline
\end{tabular}




\begin{tabular}{|c|c|}
\hline & publicly disclosed. \\
\hline Assessment & Largely Compliant \\
\hline Comments & $\begin{array}{l}\text { FI has made a motion to the government for a large increase in the number of specialists in } \\
\text { its employ. The supervisor cannot, however, with the present level of remuneration } \\
\text { compete with the private sector. To improve its capacity to supervise particularly the more } \\
\text { complex activities of banks, e.g., related to market risks, the supervisor has to be able to } \\
\text { increase its competitiveness as an employer. The relatively large increase in personnel } \\
\text { coincides with FI implementing the new model for risk assessment. }\end{array}$ \\
\hline Principle 1(3) & $\begin{array}{l}\text { A suitable legal framework for banking supervision is also necessary, including provisions } \\
\text { relating to authorization of banking establishments and their ongoing supervision. }\end{array}$ \\
\hline \multirow[t]{2}{*}{ Description } & $\begin{array}{l}\text { The responsibilities of FI as to banking supervision are defined in the Banking Business } \\
\text { Act, Chapter 7. FI has issued a regulation on the licensing process. According to the } \\
\text { Banking Business Act, FI's Director General can decide to pass on a licensing decision to } \\
\text { the government in cases of great general importance. The government cannot unilaterally } \\
\text { take on itself an individual licensing matter. }\end{array}$ \\
\hline & $\begin{array}{l}\text { A bank must furnish FI with any information regarding its operations and any relevant } \\
\text { circumstances that FI requests. FI may carry out investigations at banks at such times as FI } \\
\text { considers necessary. According to Chapter } 7 \text { Section } 2 \text { the Banking Business Act, the } \\
\text { government or authorized by the government, FI may issue regulations regarding } \\
\text { information which a bank shall provide to the supervisor; safekeeping and inventory of } \\
\text { securities and financial instruments; and crime prevention measures at the bank. The } \\
\text { Capital Adequacy and Large Exposures Act likewise confers the supervisor powers to give } \\
\text { detailed provisions. }\end{array}$ \\
\hline Assessment & Compliant \\
\hline Comments & None \\
\hline Principle 1(4) & $\begin{array}{l}\text { A suitable legal framework for banking supervision is also necessary, including powers } \\
\text { to address compliance with laws, as well as safety and soundness concerns. }\end{array}$ \\
\hline \multirow[t]{2}{*}{ Description } & $\begin{array}{l}\text { According to the Banking Business Act, FI may decide to enjoin the execution of a decision } \\
\text { where a bank has taken a decision which is in contravention of the laws which regulate the } \\
\text { banks or against the bank's articles of association. When the decision has already been } \\
\text { executed, FI may order the bank to rescind the decision, where possible. } \\
\text { FI has, according to the Banking Business Act, full access to any information from the bank } \\
\text { that FI deems necessary. FI may carry out inspections at banks at such times, as FI } \\
\text { considers necessary to review compliance with internal rules and external laws and } \\
\text { regulations. }\end{array}$ \\
\hline & $\begin{array}{l}\text { FI has the possibility to take actions against a bank's decision if it is in contravention of } \\
\text { relevant law or against the bank's articles of association. According to Chapter } 7 \text { Section } 23 \\
\text { the Banking Business Act, FI may issue orders or injunctions on pain of a conditional fine. } \\
\text { FI may also revoke the bank's charter or issue warning to a bank under specific } \\
\text { circumstances. }\end{array}$ \\
\hline Assessment & Compliant \\
\hline Comments & $\begin{array}{l}\text { According to the preliminary paper by the Banking Law Committee of 1998, the supervisor's } \\
\text { powers of remedial action should be increased. }\end{array}$ \\
\hline Principle 1(5) & $\begin{array}{l}\text { A suitable legal framework for banking supervision is also necessary, including legal } \\
\text { protection for supervisors. }\end{array}$ \\
\hline Description & $\begin{array}{l}\text { While the legislation contains no provisions for legal protection concerning explicitly the FI } \\
\text { and its employees, civil cases and cases regarding claims for damages must always be } \\
\text { addressed to FI and not to the employee. The Law on Damage Compensation states that the } \\
\text { employer has normally to bear the cost of compensation for damage caused by error or } \\
\text { mistake by its employees (Chapter 3, Section 2). An employer may seek damages from the }\end{array}$ \\
\hline
\end{tabular}




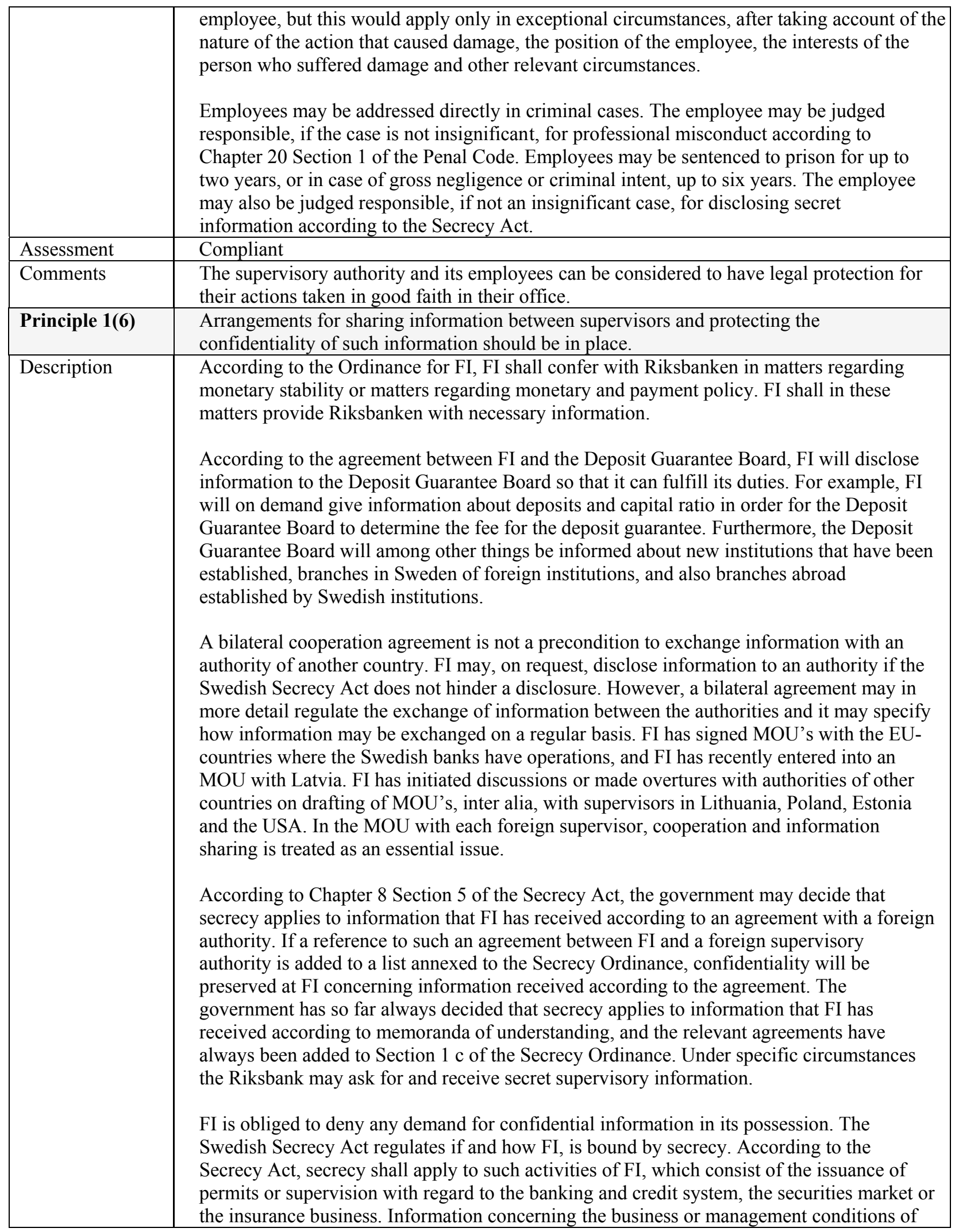




\begin{tabular}{|c|c|}
\hline & $\begin{array}{l}\text { the person whom FI's activities concerns, is protected by secrecy, if it can be assumed that } \\
\text { economic losses would be entailed if the information should be disclosed. Furthermore, } \\
\text { information concerning the economic conditions of personal circumstances of the client of a } \\
\text { company under supervision by FI is protected by secrecy. } \\
\text { Chapter } 14 \text { of the Secrecy Act provides the situations when disclosure is mandatory under } \\
\text { Swedish law. Secrecy shall not hinder the communication of information to for example the } \\
\text { Swedish Parliament and the Swedish government and another supervisory authority. } \\
\text { Furthermore, confidential information concerning suspicion of crime may be disclosed to } \\
\text { the Public Prosecution Authority, the Police force or to an authority which has to take } \\
\text { action against the crime if imprisonment is prescribed for the crime and this is presumed to } \\
\text { give rise to another sanction than fine penalty. Information that FI receives according to an } \\
\text { agreement with a foreign authority cannot be disclosed if disclosure were in breach of the } \\
\text { agreement. }\end{array}$ \\
\hline Assessment & Compliant \\
\hline Comments & $\begin{array}{l}\text { The rules of confidentiality regarding the information FI has access to in the discharge of its } \\
\text { duties, as well the disclosure of such information, are in place. FI has yet to enter into } \\
\text { MOU's with some of the authorities in countries where Swedish banks have a presence. }\end{array}$ \\
\hline Principle 2. & $\begin{array}{l}\text { Permissible Activities } \\
\text { The permissible activities of institutions that are licensed and subject to supervision as } \\
\text { banks must be clearly defined, and the use of the word "bank" in names should be } \\
\text { controlled as far as possible. }\end{array}$ \\
\hline Description & $\begin{array}{l}\text { The term "bank" is defined in Chapter } 1 \text { Section } 1 \text { the Banking Business Act as banking } \\
\text { companies, savings banks, and members' banks. Banking business may only be conducted } \\
\text { following authorization (license) from FI, or in exceptional cases from the government. An } \\
\text { authorization may only be given to banks. } \\
\text { The permissible activities of banks are defined in Chapter } 2 \text { the Banking Business Act. The } \\
\text { list corresponds to Annex } 1 \text { to the European Directive 2000/12/EC relating to credit } \\
\text { institutions. } \\
\text { A bank may engage in the following activities: } \\
\text { 1. borrow funds, inter alia, by issuing bonds or other similar debt instruments; } \\
\text { 2. grant and broker loans, inter alia, in the form of consumer loans and loans secured by } \\
\text { real property or instruments of indebtedness; } \\
\text { 3. participate in conjunction with financing, inter alia, by acquiring claims and leasing } \\
\text { personal property; } \\
\text { 4. negotiate payments; } \\
\text { 5. provide means of payment; } \\
\text { 6. issue guarantees and assume similar obligations; } \\
\text { 7. participate in issues of securities; } \\
\text { 8. provide financial advice; } \\
\text { 9. hold securities in safekeeping; } \\
\text { 10. conduct documentary credit operations; } \\
\text { 11. act as a custodian institution for securities funds; } \\
\text { 12. participate in sales of insurance services; } \\
\text { 13. provide debt collection services; } \\
\text { 14. provide bank safe deposit services; } \\
\text { 15. conduct currency trading; } \\
\text { 16. conduct securities business subject to the conditions prescribed in the Securities } \\
\text { Operations Act; and } \\
\text { 17. provide credit information subject to the conditions prescribed in the Credit }\end{array}$ \\
\hline
\end{tabular}


Information Act.

In addition, banks may conduct operations that have a natural connection with deposits or with operations as set forth in the list. Chapter 2 the Banking Business Act also states additional permissible activities that do not have a direct connection with banking business such as acquisition of shares and so on. Where a special cause exists, a bank may be authorized by FI to provide postal services. Further details are also issued in FI's regulations and guidelines.

No entity other than a bank, the Central Bank of Sweden, the Swedish General Mortgage Bank and foreign banking undertakings may use the word "bank" in its name or otherwise in conjunction with a description of its business. However, an association or other legal entity with a close affiliation to a bank may, with FI's authorization, use the word "bank" in its name.

According to Chapter 7 Section 21 the Banking Business Act, where any person conducts banking business without being licensed to do so, FI shall order such person to cease such operations on pain of a conditional fine. Where there is doubt as to whether the operations include deposits, FI may order the person conducting the operations to furnish any information regarding the operations required in order to determine whether deposit operations are being conducted. As to foreign undertakings, an order may be addressed to both the undertaking as well as any person conducting operations in Sweden on behalf of the undertaking.

Banking business is defined in the Banking Business Act as operations which include the acceptance of deposits on account where the balance is determined in nominal amounts and is available to the depositor on short notice. Banking business may only be conducted following authorization and an authorization may only be given to banks. However, where an undertaking accepts customer funds on account, they do not constitute deposits provided the balance for each customer does not exceed SKR 15,000 and the balance is only available to the customer for payment for goods and services which are produced or sold by the undertaking; or by another undertaking in the same group or in the same group of undertakings with close economic affiliation or in connection with the closure of the account.

According to Chapter 1 Section $2 \mathrm{~b}$ the Banking Business Act, it is not considered to be a banking activity if an economic association conducts deposit operations, provided the association: receives deposits only from its own members; only intends to use members' deposits to satisfy the financing requirements of the members; only accepts natural persons as members; and has no more than 1,000 members. No new association may use the legal provision as a basis for pursuing these activities without a license.

An undertaking which offers deposits on account in accordance with Chapter 1, Sections $2 \mathrm{a}$ and $2 \mathrm{~b}$, the Banking Business Act shall specify in conjunction with its advertising, displays, and other marketing of account services that the balance on the account is not covered by the deposit guarantee in accordance with the Deposit Guarantee Act. Prior to execution of an account agreement, the account operator must inform the depositor that the balance on the account is not covered by the deposit guarantee. The information must be provided in writing. The Marketing Practices Act shall apply in the event an undertaking fails to provide the information or other information that is of particular significance from a consumer perspective.

\begin{tabular}{l|l} 
Assessment & Compliant \\
\hline Comments
\end{tabular} 


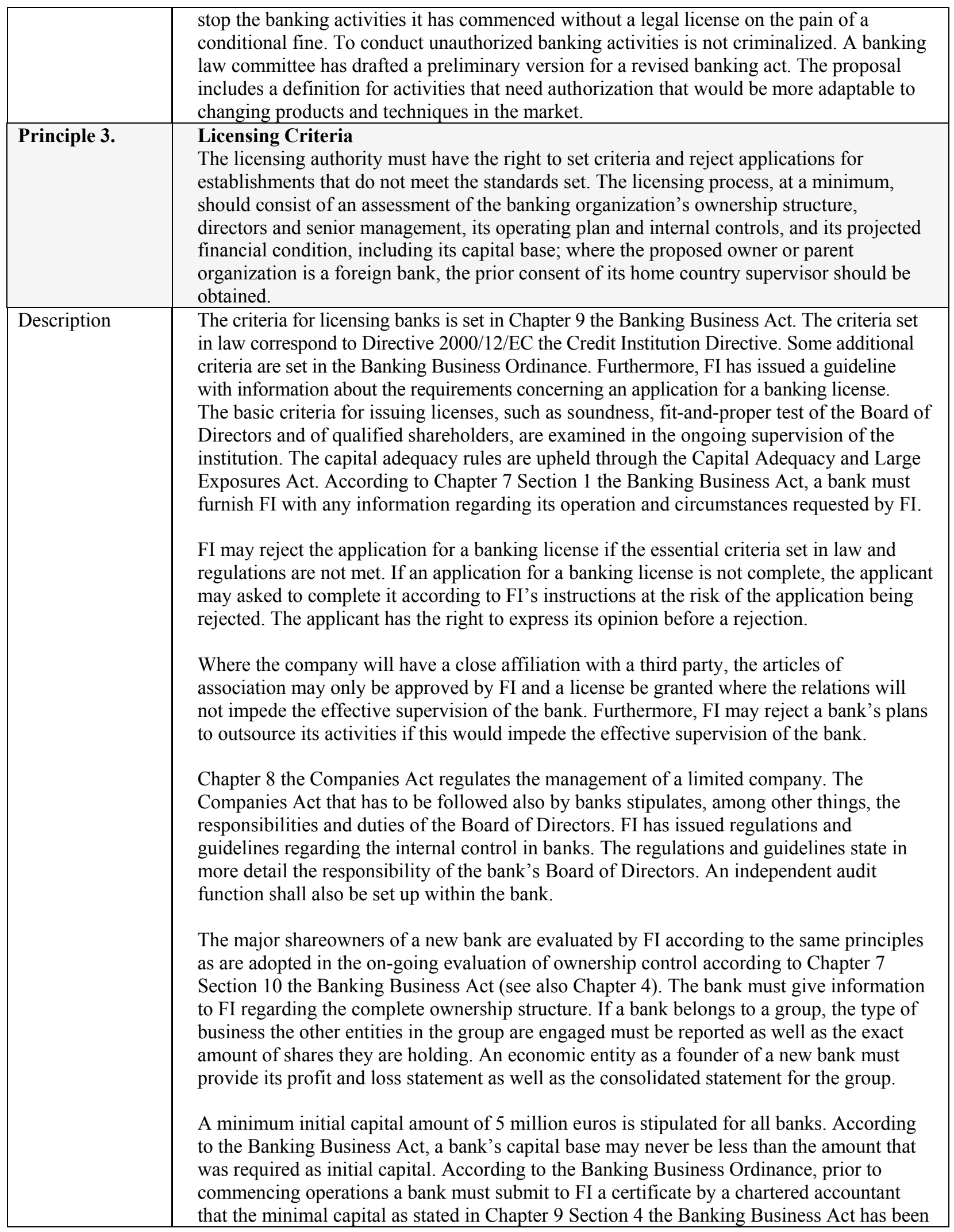


fully paid.

FI evaluates the proposed Board of Directors and the managing director, both when they are proposed in an application for banking license and during on-going business. Chapter 9 Section 3 the Banking Business Act stipulates that a charter shall be granted where the persons who will constitute the company's boards of directors or serve as the managing director or the acting managing director possess sufficient insight and experience in order to participate in the management of a bank and are otherwise suitable for such a task. The guidelines FFFS 1998:14 issued by FI gives more detailed information of the fit-andproper-test. A charter is not granted if a member of the Board of Directors or the managing director or his deputy has to a significant extent failed to perform his obligations in commercial operations or in other financial affairs or has been convicted of a serious criminal offence. All members of a bank's senior management are not subject to such a fitand-proper test.

According to the Banking Business Ordinance, a bank's operating plan has to be submitted in connection with an application for a license. The plan must include a description of the projected operations of the bank. FI reviews that corporate governance and internal controls of the bank are in accordance with the principles set out in law and in the guidelines by FI. FI monitors that the institution have written procedures for important spheres of activity and adequate internal control mechanisms. Particularly, there must be a description of risk monitoring and management of credit risk, interest rate risk, and exchange and liquidity risks. FI guidelines require that internal regulations for the bank's Board of Directors be drawn up. FI has also issued regulations and guidelines regarding the prevention of criminal activities connected with banking activities.

According to the Banking Business Ordinance, a prognosis for the bank's economic results for the next three years must be submitted to FI. The forecast must be drafted for both the bank and the group that the bank is going to be part of. There must also be an analysis of the capital requirements for the different risk areas.

If a foreign banking company which maintains its registered office in a country within the EEA intends to establish a branch in Sweden, it is not required to a obtain a license from FI. FI receives notification from a competent supervisory authority in the undertaking's home country which contains prescribed information. The procedure in law corresponds to that set forth in the Credit Institutions Directive. As to foreign banking companies from outside the EEA intending to establish a branch in Sweden, a license issued by FI is needed. Prior to issuing a license, FI follows the policy of asking the home country authority's opinion in order to make sure that the planned business may be assumed to fulfill the requirements of sound banking operations.

As regards foreign banking companies intending to establish a subsidiary in Sweden, an application for authorization must always be submitted to FI. If the owners are foreign physical persons or foreign legal entities, it is FI's policy to contact the foreign supervisory authority in order to determine the suitability of the foreign owners of the bank. No requirement to obtain the foreign authority's statement of no objection is stated in law.

If FI determines that the license was knowingly based on false information, FI can ask the bank for corrections. If on the basis of the false information the sound development of the bank's operations may be expected to be jeopardized and the bank's management has been proved to be unsuitable to exercise such operations to which the charter relates, the bank's charter may be revoked or the bank may be given a warning.

The assessment of the application by FI is not regularly directed to the ability of the 


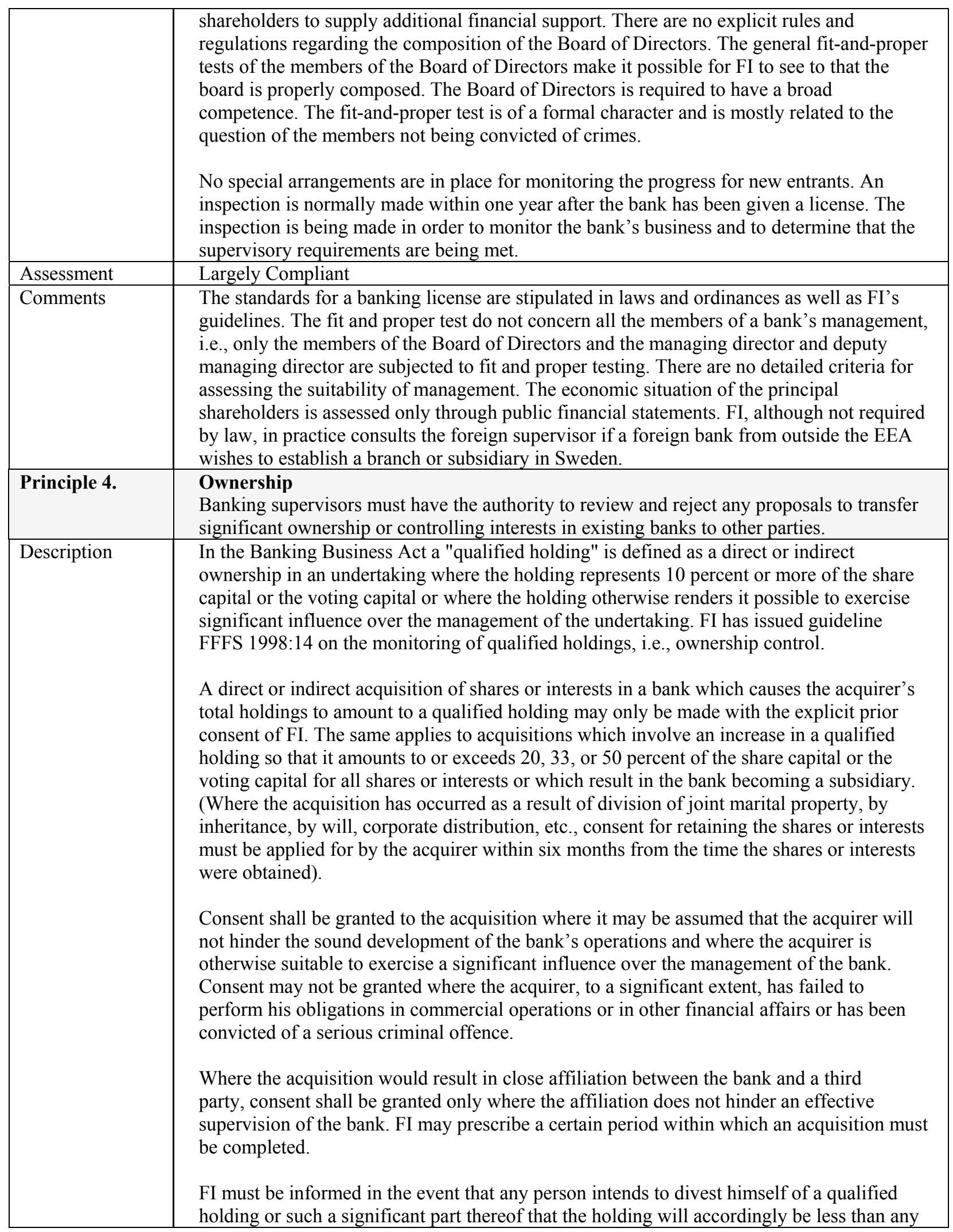




\begin{tabular}{|c|c|}
\hline & 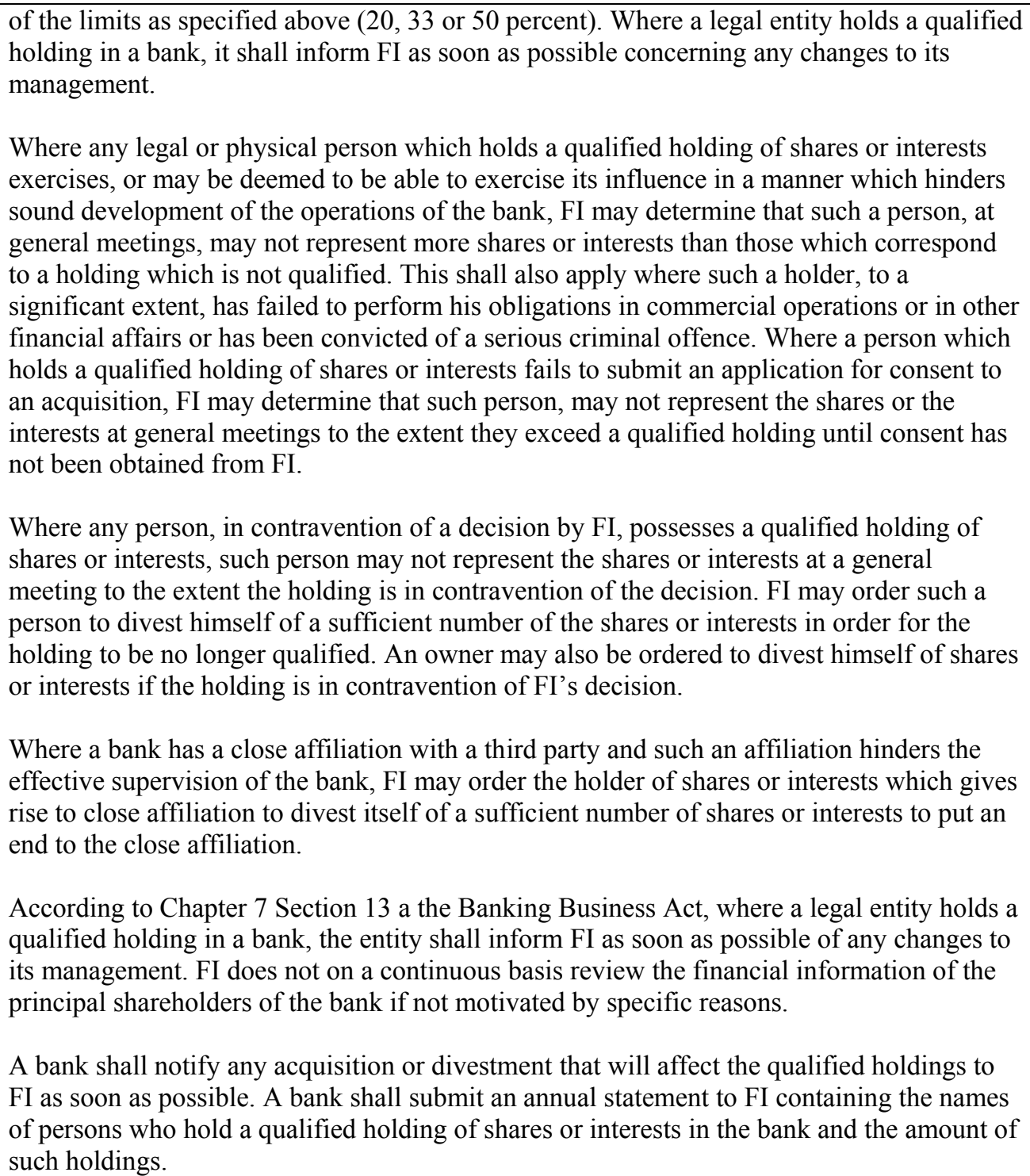 \\
\hline Assessment & Compliant \\
\hline Comments & None \\
\hline Principle 5. & $\begin{array}{l}\text { Investment Criteria } \\
\text { Banking supervisors must have the authority to establish criteria for reviewing major } \\
\text { acquisitions or investments by a bank and ensuring that corporate affiliations or structures } \\
\text { do not expose the bank to undue risks or hinder effective supervision. }\end{array}$ \\
\hline Description & $\begin{array}{l}\text { According to Chapter } 2 \text { Section } 5 \text { the Banking Business Act, a bank may acquire another } \\
\text { bank's business, provided the acquisition is not deemed to be prejudicial to the public } \\
\text { interest. If the acquisition relates to all or a significant part of the business, an authorization } \\
\text { by FI is required. A bank may, equally following authorization, acquire shares or interests } \\
\text { in a Swedish or foreign bank or in a Swedish or foreign non-banking undertaking if the } \\
\text { acquisition may be deemed to be beneficial for the banking system or the general public. } \\
\text { The same applies to guarantees or subordinated loans issued by such companies. A bank } \\
\text { may be authorized to acquire shares or interests in a Swedish or foreign insurance company, } \\
\text { and a savings bank or a cooperative bank may be authorized to acquire shares in a Swedish } \\
\text { insurance company, if the acquisition is included as a part of the organization of the }\end{array}$ \\
\hline
\end{tabular}




\begin{tabular}{|c|c|}
\hline & 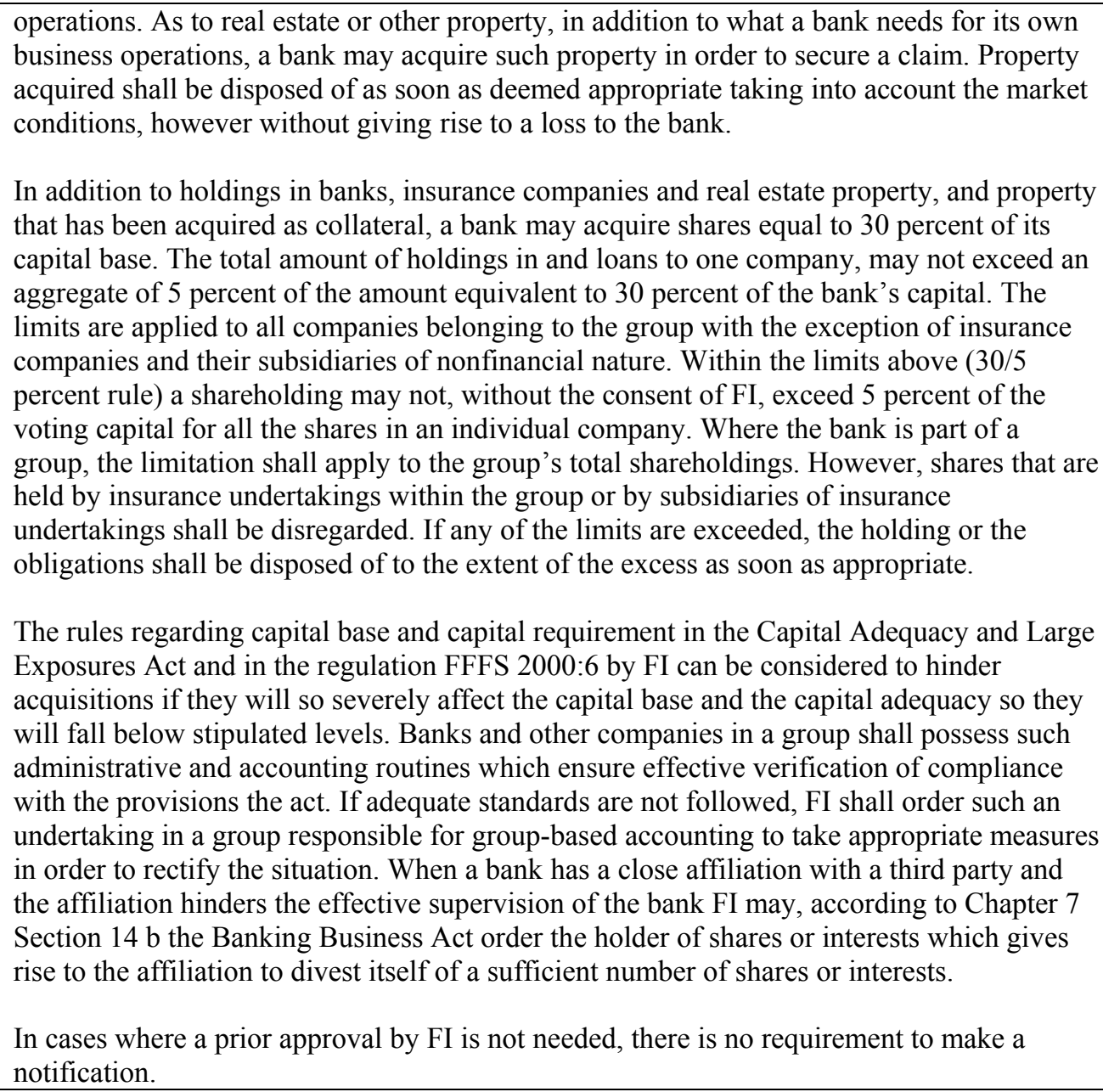 \\
\hline Assessment & Compliant \\
\hline Comments & $\begin{array}{l}\text { Laws set limits for investments in other undertakings. FI's consent is needed for large } \\
\text { individual acquisitions. In laws and regulations there are, however, no requirements as to } \\
\text { reporting to the supervisor of certain types of investments. }\end{array}$ \\
\hline Principle 6. & $\begin{array}{l}\text { Capital Adequacy } \\
\text { Banking supervisors must set minimum capital adequacy requirements for banks that } \\
\text { reflect the risks that the bank undertakes, and must define the components of capital, } \\
\text { bearing in mind its ability to absorb losses. For internationally active banks, these } \\
\text { requirements must not be less than those established in the Basel Capital Accord. }\end{array}$ \\
\hline Description & $\begin{array}{l}\text { All EU directives on capital adequacy are implemented through the Capital Adequacy and } \\
\text { Large Exposures Act and regulation issued by FI concerning capital adequacy and large } \\
\text { exposures (FFFS 2000:6). The Basle Capital Accord with amendments has been complied } \\
\text { with. } \\
\text { The rules on capital adequacy apply not only to internationally active banking companies } \\
\text { but also to the following institutions: savings banks, cooperative banks, credit market } \\
\text { companies, securities companies, and the Swedish Ship Mortgage Bank. } \\
\text { The EU directive on the own funds of credit institutions is fully implemented through } \\
\text { Chapter } 2 \text { the Capital Adequacy and Large Exposures Act and Chapter } 3 \text { of the regulation } \\
\text { (FFFS 2000:6) of FI. Capital adequacy is calculated on solo and consolidated basis }\end{array}$ \\
\hline
\end{tabular}




\begin{tabular}{|c|c|}
\hline & 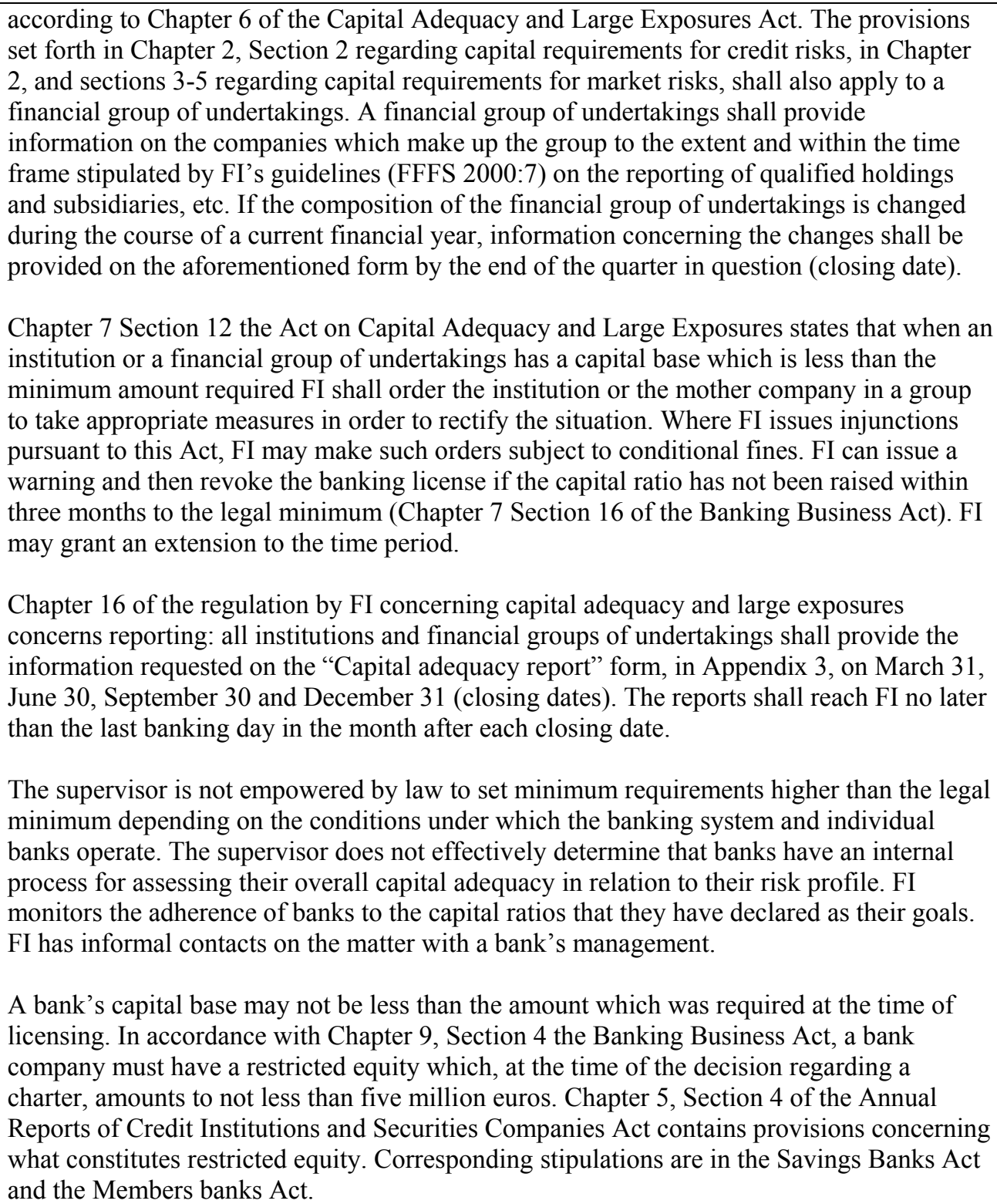 \\
\hline Assessment & Compliant \\
\hline Comments & $\begin{array}{l}\text { The capital adequacy requirements are in line with the Basle Accord. The supervisor has no } \\
\text { legal powers to require a ratio higher than the legal minimum on the grounds of higher risk } \\
\text { content in a bank's business or the general operating environment. }\end{array}$ \\
\hline Principle 7. & $\begin{array}{l}\text { Credit Policies } \\
\text { An essential part of any supervisory system is the independent evaluation of a bank's } \\
\text { policies, practices, and procedures related to the granting of loans and making of } \\
\text { investments and the ongoing management of the loan and investment portfolios. }\end{array}$ \\
\hline Description & $\begin{array}{l}\text { Section } 3 \text { of the general guideline (FFFS 1995:49) of FI concerning credit risks in credit } \\
\text { institutions and securities companies require that the board of the bank establish credit } \\
\text { policies, practices and procedures. The board of the bank should according to Section } 10 \text { in } \\
\text { the guideline (FFFS 1999:12) on management, internal information and internal control } \\
\text { also issue guidelines for the internal audit on how to monitor the adherence of the credit } \\
\text { policies, practices and procedures. The audit function should report direct to the board of }\end{array}$ \\
\hline
\end{tabular}


the bank and to the managing director. In the general guideline it is also required that the board should ensure that policies, practices and procedures and review of risks are sufficient.

Regarding credit risks a bank should have a specific controller function regularly monitoring the credit risks according to Section 15 in the general guideline (FFFS 1995:49). Control should be directed, in particular, to compliance of credit policies and instructions, identification, measurement, and reporting of credit risks. The quality of credit procedures and monitoring should be reported to management on a continuous basis.

FI verifies, through periodic on-site examinations the presence of policy and instructions and how these are implemented and monitored within the bank. At on-site examinations the adherence to the stipulation of the general guideline (FFFS 1995:49) is assessed.

In Chapter 2 Section 17 of the Banking Business Act there is a requirement that credits be extended to connected parties on an arm's length basis on normal terms applied in the bank's business. In certain cases FI has powers to determine to which parties the rule is to be applicable. Banks are expected to create a specific list with all physical and legal entities belonging to "connected or related parties"/ the group and, if credits are granted, with specifications as to size and terms and conditions. The list must be handed over to FI on request.

In Section 14 in the guideline (FFFS 1995:49) on credit risks it is required that the board of the bank establish an internal communication system enabling the board to have access to all relevant information on the credit function and that all relevant persons and bodies within the bank receive the information on necessary for their duties. The general guideline (FFFS 1999:12) by FI also requires that the board should establish an information system providing relevant information about the business activities at any time. It is also stated in Section 6 of the guideline that unless otherwise stipulated, information must be reported to FI in the format it is available through the bank's internal communication system.

In Chapter 7, Section 1, the Banking Business Act it is stated that a bank has to provide FI with requested information about its business activities and related circumstances, and FI is vested with the authority to make on-and off-site examinations whenever it deems necessary.

Legally there are no formal requirements for the banks to have in use various levels of decision-making. In practice all banks apply segregated levels of decision depending on the risks and the sort of business area concerned. The articles of association of a bank establish the general guidelines for granting of credits and indicate possible limitations. Accordingly, the credit policy that has to be established according to guideline (FFFS 1995:49) must be in line with the articles of association. Procedures and delegation of powers in connection with the granting of credits are to be described in the credit instructions. It must be stated in the instructions which decisions must always be made by the board.

Section 14 in the guideline (FFFS 1995:49) requires that the board should establish a management information system providing relevant and well structured information about handling and granting of credits and related risks. Section 6 in the guideline

(FFFS 1999:12) requires that the board of the bank establish an information system providing relevant information about the business activities at any time.

In Chapter 4 Section 8a in the Regulation (FFFS 2000:18) concerning the annual reports of banks it is required that each bank monitor all its problem credits, disregarding the type of borrower or the domicile of the borrower. Monitoring has to take place at least in 


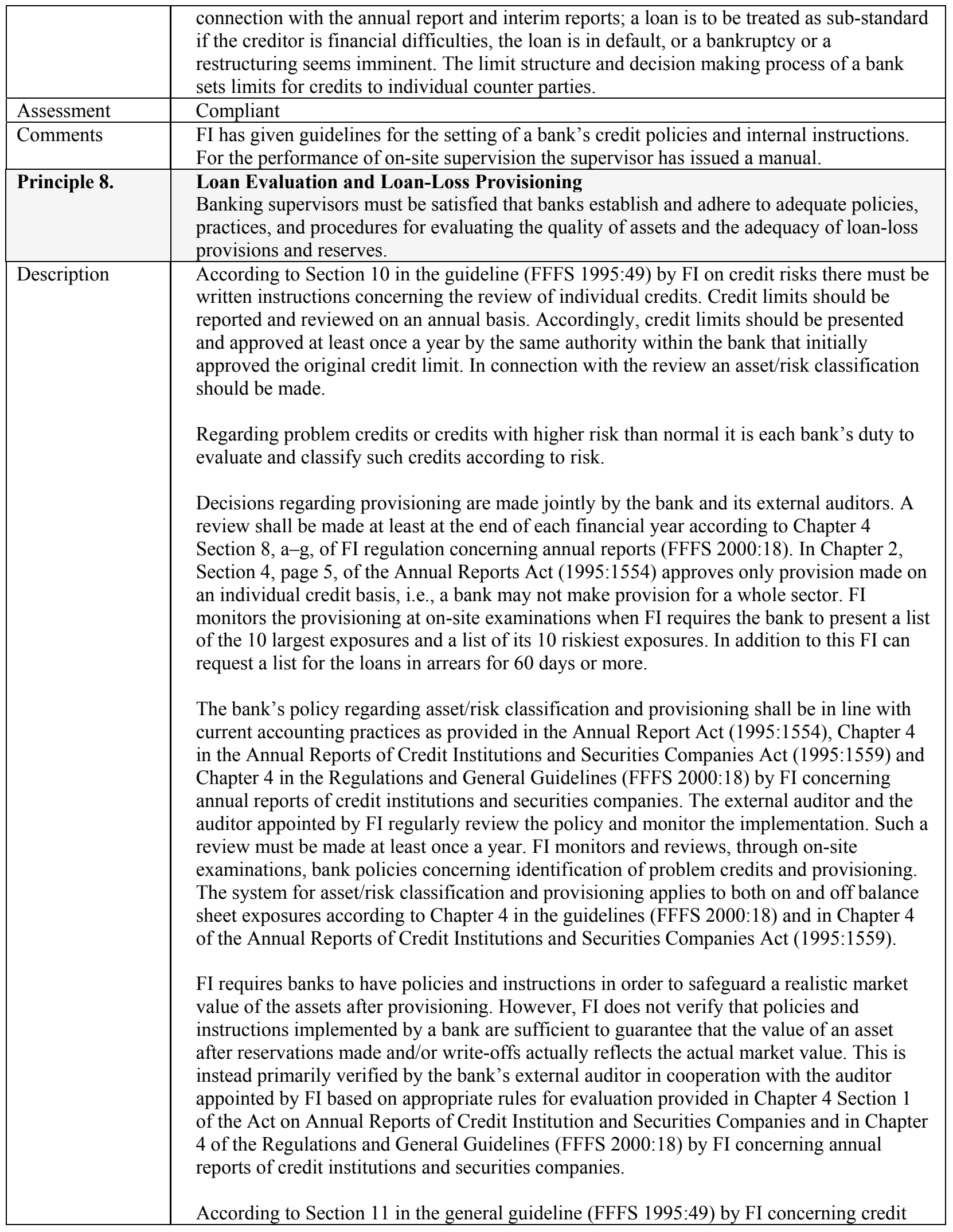


risks, a bank should establish a system enabling analysis of the structure of the whole credit portfolio, the quality and its development over time. It is the responsibility of each individual bank to implement appropriate procedures and sufficient organizational resources. Regarding problem credits and collecting past due loans FI monitors whether a bank has appropriate/ sufficient resources for the ongoing oversight of problem credits and for collecting past due loans. FI 's unit of statistics receives quarterly information from banks on problem credits. Collecting past due loans is an integrated and normal part of credit handling by banks. The handling of problem credits and collecting past due loans within the bank is regularly reviewed in connection with FI's on-site examinations.

FI does not have legal powers to require a bank to strengthen its lending practices or credit granting standards, or to strengthen its overall financial strength. Sections 4 and 8 in the General Guidelines (FFFS 1995:49) concerning credit risks require that credit policies contain guidelines for sound credit. FI may not legally require a bank to alter the level of loan loss provisions. However, FI makes recommendations with respect to banks' overall credit standards and provisioning practices. Rules and limits concerning provisions are set in Chapter 4 of the Act on Annual Reports and the regulation (FFFS 2000:18) by FI on annual reports of credit institutions and securities companies.

FI's unit for statistics receives information problem loans and provisioning on a quarterly basis in accordance with Section 2 in Regulation (FFFS 2000:23) concerning quarterly and yearly reporting of financial accounts. Sections 8 and 10 of the guideline (FFFS 1995:49) on credit risks require that instructions be set up for assessing of collateral in connection with the granting of new credits and when credit exposures are reviewed.

The Annual Report Act, the Act on Annual Reports of Credit Institutions and Securities Companies and the 4 Chapter in regulation (FFFS 2000:18) by FI concerning annual reports of credit institutions and securities companies require that collateral shall be reviewed at least annually. Credit limits should be reported and reviewed at least annually according to Section 9 in the guideline (FFFS 1995:49) by FI.

Chapter 4 Section 8a in the regulation (FFFS 2000:18) by FI concerning annual reports of credit institutions and securities companies states when a loan shall be identified as impaired. A loan is classified as impaired on the basis of information of the creditor's financial difficulties, and if the loan has not been serviced according to contract; interest payments in arrears for more than 60 days is given as a strong indication. A substandard loan is valued according to the likely repayment expectations which is based on either the future discounted cashflows, the realistic value of collateral or the market value of the receivable.

The valuation of collateral is required to reflect the net realizable value. Collateral is required to be valued at current value, which according to Chapter 4 Section 5 in the regulation (FFFS 2000:18) is realizable/ market value less the estimated transaction costs. The current value equals the market value when such has been established. If no market is established the current value has to be based on various estimations.

Loans are required to be classified when payments are contractually 60 days in arrears, judged from the original terms of the loan according regulation (FFFS 2000:18) by FI. Refinancing of loans that would otherwise fall into arrears does not lead to improved classification for such loans. Rules for restructuring loans and declassification of loans to normal status are stipulated in Chapter 4, Section $8 \mathrm{f}$ and g, in regulation (FFFS 2000:18) by FI.

Chapter 4, Section 8 c, in regulation FFFS 2000:18 by FI requires that valuation, 


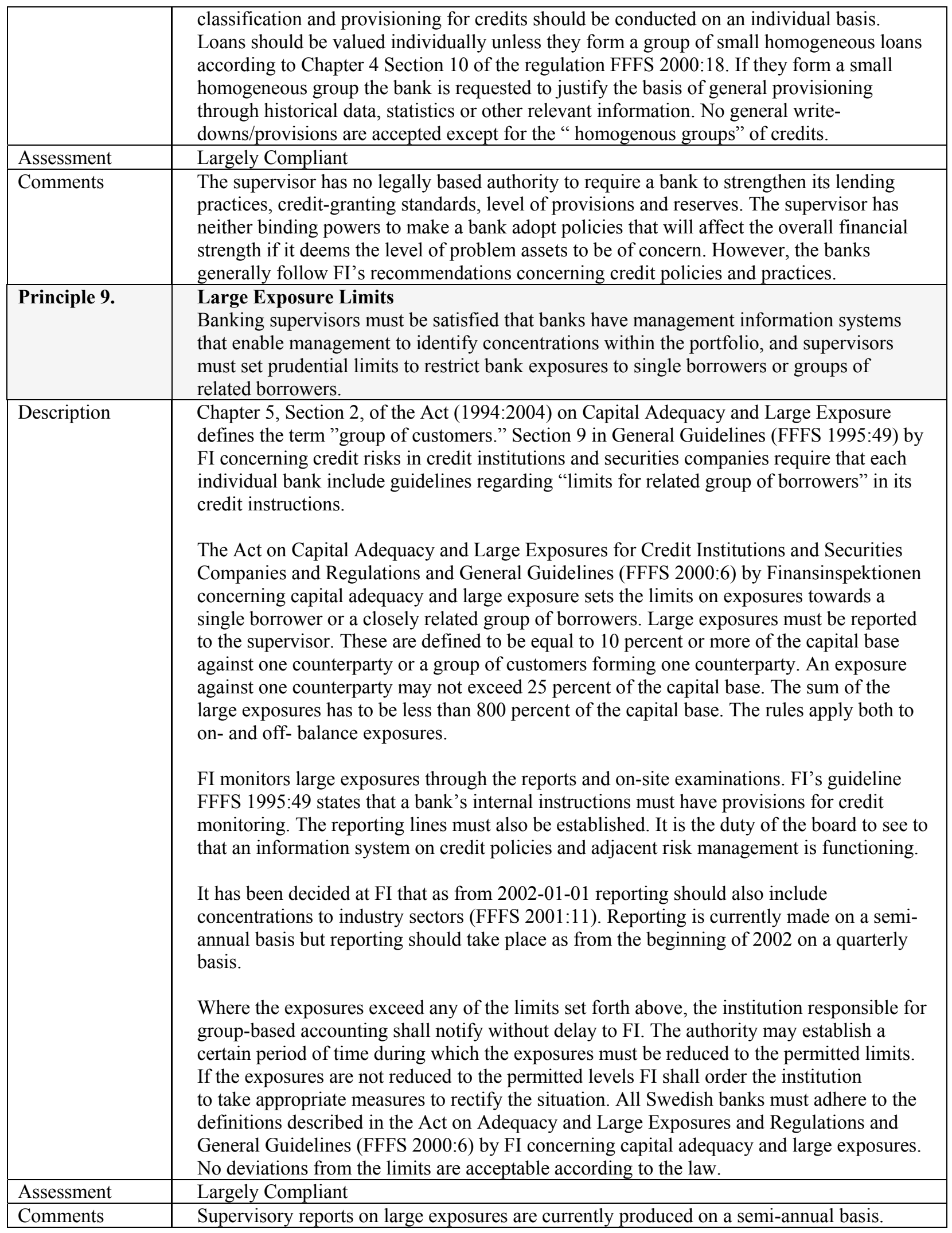




\begin{tabular}{|c|c|}
\hline & $\begin{array}{l}\text { From } 2002 \text { onward reports will be made on a quarterly basis. Reporting will from the } \\
\text { beginning of } 2002 \text { include information on exposures to sectors. }\end{array}$ \\
\hline Principle 10. & $\begin{array}{l}\text { Connected Lending } \\
\text { In order to prevent abuses arising from connected lending, banking supervisors must have } \\
\text { in place requirements that banks lend to related companies and individuals on an arm's- } \\
\text { length basis, that such extensions of credit are effectively monitored, and that other } \\
\text { appropriate steps are taken to control or mitigate the risks. }\end{array}$ \\
\hline \multirow[t]{6}{*}{ Description } & $\begin{array}{l}\text { Connected lending is regulated in Chapter } 2 \text { Section } 17 \text { of the Banking Business Act where } \\
\text { a comprehensive definition of "connected or related parties" exists. The following persons } \\
\text { are included in the definition: } \\
\text { 1. a member of the Board of Directors; } \\
\text { 2. a delegate in a management position who, alone or together with a third party, is } \\
\text { authorized to determine lending matters incumbent on the Board of Directors; } \\
\text { 3. an employee who hold a senior position within the bank; } \\
\text { 4. shareholders or owners of interests other than the State with a holding equal to at least } \\
\text { three percent of the issued share capital; } \\
\text { 5. a spouse or cohabitee of a person referred to above; or } \\
\text { 6. a legal entity in which such persons as referred to above have a significant financial } \\
\text { interest in their capacity as owners or members. }\end{array}$ \\
\hline & $\begin{array}{l}\text { Loans may not be extended on terms and conditions different from those normally imposed } \\
\text { on customers. FI has discretion to make a judgment about connectedness as to items } 2 \text { and } 3 \\
\text { above. Each individual bank has to create a specific list including all physical and legal } \\
\text { entities belonging to the group and when credits are granted on what terms and conditions } \\
\text { and to what amount. The list must be handed over to FI on request. }\end{array}$ \\
\hline & $\begin{array}{l}\text { There is no formal recommendation that credits to connected parties be handled and/or } \\
\text { subject to approval by a body of a certain level in a bank's hierarchy. It is stated that such } \\
\text { credits shall be handled and approved in accordance with the normal procedure in the bank. }\end{array}$ \\
\hline & $\begin{array}{l}\text { Sections } 2 \text { and } 4 \text { of the guideline (FFFS 1998:22) by FI concerning handling of ethical } \\
\text { questions require that each individual bank establish ethical guidelines regarding granting } \\
\text { of credits. The guideline requires in particular that banks have systems set up for } \\
\text { monitoring credit granting out of moral, ethical and legal perspectives. It is stated in Section } \\
8 \text { of the guideline concerning credit risk (FFFS 1995:49) that the same person is not to have } \\
\text { both credit-granting functions and customer account responsibilities. }\end{array}$ \\
\hline & $\begin{array}{l}\text { Chapter } 2 \text { Section } 17 \text { of the Banking Business Act requires that credit granting to } \\
\text { "connected and related parties "shall correspond to normal terms and conditions applied by } \\
\text { the bank. FI has no authority to set limits to loans to connected parties or deduct such loans } \\
\text { from capital when assessing capital adequacy. The total amount of loans to connected } \\
\text { parties shall be handled on the same basis as loans to other borrowers of the bank, and is } \\
\text { limited only by the rules in the Act on Capital Adequacy and Large Exposures. The act also } \\
\text { requires that the board of a bank be able to identify the cases of connected lending. FI has } \\
\text { followed a policy of requiring banks to have in the specification the names of all physical } \\
\text { and legal entities identified as connected or related parties and the terms and conditions and } \\
\text { the amount as well as the total amount. FI does not on a continuous basis obtain } \\
\text { information on connected lending from banks. }\end{array}$ \\
\hline & $\begin{array}{l}\text { Chapter } 2 \text { Section } 17 \text { of the Banking Business Act provides a definition of a connected } \\
\text { party. In individual cases FI has authority to determine who is to be included. The size of } \\
\text { the lending to a connected parties is not limited in special rules but it is ultimately set by the }\end{array}$ \\
\hline
\end{tabular}




\begin{tabular}{|c|c|}
\hline & general rules in the Act on Capital Adequacy and Large Exposures. \\
\hline Assessment & Largely Compliant \\
\hline Comments & $\begin{array}{l}\text { The rule of arm's length and the concept of connected parties are established in law. There } \\
\text { is no requirement that credits to connected or related parties should be decided at a certain } \\
\text { level. FI has no authority to set individual limits to connected lending or deduct loans } \\
\text { extended on concessionary grounds from the bank's capital. Although authorized to do so } \\
\text { in law, FI has not deemed it necessary to issue regulations on the register of connected } \\
\text { lending. No arrangements have been made for regular reporting to the supervisor of } \\
\text { connected lending on an individual or aggregate basis. }\end{array}$ \\
\hline Principle 11. & $\begin{array}{l}\text { Country Risk } \\
\text { Banking supervisors must be satisfied that banks have adequate policies and procedures for } \\
\text { identifying, monitoring, and controlling country risk and transfer risk in their international } \\
\text { lending and investment activities, and for maintaining appropriate reserves against such } \\
\text { risks. }\end{array}$ \\
\hline Description & $\begin{array}{l}\text { The FI determines through onsite and offsite inspections that banks' policies and procedures } \\
\text { give due regard to the identification, monitoring and control of country risk and transfer risk. } \\
\text { Country risk and transfer risk is integrated as a part of the total credit risk. } \\
\text { Section } 14 \text { in the guideline (FFFS 1995:49) by FI on credit risks requires that the board of a } \\
\text { bank should establish a management information system providing relevant and well } \\
\text { structured information about handling and granting of credits and related risks. The guideline } \\
\text { does not specifically mention country risks. FI verifies through on-site examinations that the } \\
\text { banks have adequate information systems, risk management systems and internal control } \\
\text { systems. }\end{array}$ \\
\hline & $\begin{array}{l}\text { No general provision for country or transfer risk is permitted in the law and regulations. } \\
\text { Provisioning may only be made for credits identified as problem credits according to Chapter } \\
4 \text { Section } 8 \mathrm{~h} \text { in the regulation (FFFS 2001:19) by FI concerning annual reports. Each credit } \\
\text { shall be evaluated individually. It is also stated in the regulation that provisioning, if any, } \\
\text { shall be stated in the annual report. The bank decides the appropriate provisioning for each } \\
\text { individual credit and the auditor verifies the provisioning. }\end{array}$ \\
\hline & Riksbank provides upon request FI with information on country risks by bank. \\
\hline Assessment & Largely Compliant \\
\hline Comments & $\begin{array}{l}\text { Finansinspektionen receives and evaluates country risk and transfer risk on a quarterly basis } \\
\text { on the basis of information derived from quarterly reports. FI has no specific guidelines } \\
\text { concerning country risk. Finansinspektionen has access to the reports given by the banks to } \\
\text { the Riksbank regarding country risk exposures to individual countries. A bank decides the } \\
\text { appropriate provisioning for each individual credit and the auditor verifies the provisioning. }\end{array}$ \\
\hline Principle 12. & $\begin{array}{l}\text { Market Risks } \\
\text { Banking supervisors must be satisfied that banks have in place systems that accurately } \\
\text { measure, monitor, and adequately control market risks; supervisors should have powers to } \\
\text { impose specific limits and/or a specific capital charge on market risk exposure, if } \\
\text { warranted. }\end{array}$ \\
\hline Description & $\begin{array}{l}\text { The directive on the Capital charge for market risk (CAD 1) was implemented in } \\
\text { January } 1996 \text { by the Act on Capital Adequacy and Large exposures. FI has issued the } \\
\text { regulation (FFFS 2000:6) concerning capital adequacy and large exposures. In } 2000 \text { FI } \\
\text { implemented general guideline (FFFS 2000:10) concerning management of market and } \\
\text { liquidity risks in credit institutions and investment firms. Section } 6 \text { of the general guideline } \\
\text { stipulates that banks should have written policies and instructions concerning identification, } \\
\text { measuring, reporting, monitoring and control of market risk. FI's guideline (FFFS 1999:12) } \\
\text { concerning management, internal information and internal control also deals with the issue } \\
\text { of policies. Section } 4 \text { of these general guidelines stipulates that the Board of Directors }\end{array}$ \\
\hline
\end{tabular}


should see to it that the management and control of risks in the bank are arranged in a satisfactory manner. Policies for relevant risks should be issued for this purpose. FI monitors the compliance of the laws, regulations and general guidelines through the analysis of reports and by carrying out on-site supervision. In the on-site supervisory work inspectors are guided by relevant manuals.

Section 7 of FI's general guideline (FFFS 2000:10) on management of market and liquidity risks stipulates that banks must have limits for market risks. The limits should be set for the bank as a whole and for position taking units. Limits should be set for an operational unit as a whole and for different trading desks, products and individual traders. FI examines banks' limits and limit setting policies and procedures through the on-site supervision work.

For those banks' that have authorization to use the Internal Models Approach for market risk capital requirements, FI has the power to set the multiplier above the stipulated 3 subsequent to performing a qualitative valuation of a bank's risk management systems (Chapter 11 Section 7 in FI's regulation on capital adequacy and large exposures, FFFS 2000:6). At present no Swedish bank has the authorization to use the Internal Models Approach for market risk capital requirements. Two banks have applied for an authorization and FI is currently in the process of evaluating these models. Apart from the above the supervisor has no powers to impose a capital or specific limits on market risk exposure.

Section 10 of FI's general guidelines (FFFS 2000:10) concerning management of marketand liquidity risks stipulates that banks should have adequate systems in place for controlling and reporting of market risk on a daily basis. Section 6 of FI's general guidelines (FFFS 1999:12) concerning management, internal information and internal control stipulates that the Board of Directors should see to it that there is an information system in place which at all times produces relevant information about the business. Section 4 of the same general guidelines stipulates that policies should be reviewed internally on an on-going basis. FI examines banks information systems, risk management systems and internal control systems through the on-site supervision process. For this purpose inspectors have relevant manuals to conduct their work.

Chapter 4 Section 12 of regulation on capital adequacy (FFFS 2000:6) stipulates that positions in the trading book shall be marked to market on a daily basis for measurement of capital charge. Further, Section 9 of FI's general guideline (FFFS 2000:10) concerning management of market- and liquidity risks stipulates that market valuation, made independently of position taking units, should be undertaken on a daily basis for the trading book. The valuation should be based on complete, precise and updated information about positions. Banks' valuation models and data used in the valuations are examined through the on-site supervision process. Relevant manuals are in place to assist inspectors in this work.

A bank which has the authorization to use the Internal Models Approach for market risk capital requirements shall perform stress test and on an annual basis evaluate its entire risk management system for market risks according to Chapter 11 Section 4 in FI's regulation (FFFS 2000:6). Section 8 of general guideline (FFFS 2000:10) also deals with this issue. Banks' with large and complex exposures should perform gap-analysis, sensitivity analysis etc. It is also stipulated that banks that are using Value at Risk models internally should perform stress test and scenario analysis. In the on-site supervision work FI examines banks stress tests and scenario analysis.

The market risk team consists of three persons, each with two to three years of experience at the supervisory authority. Two of the risk analysts have a master degree in financial 


\begin{tabular}{|c|c|}
\hline & $\begin{array}{l}\text { economics with mathematical emphasis, and the other has a master degree in economics. } \\
\text { Two staff members work with capital adequacy questions, and are members of the Models } \\
\text { Task Force of the Basel Committee on Banking Supervision. No one of the staff members } \\
\text { have a background in the industry. The members of the market risk team also get the } \\
\text { opportunity to attend in-house as well as external courses; more recently for example an } \\
\text { internal course in financial mathematics with a focus on market and credit risk modeling } \\
\text { techniques. } \\
\text { Section } 5 \text { of FI's guideline (FFFS 2000:10) on market and liquidity risks stipulates that it is } \\
\text { the responsibility of the managing director to secure a balance between the bank's present } \\
\text { business strategy and the level of risk incurred. The managing director's responsibility is } \\
\text { also to have guidelines and regulations issued; to have sufficient resources available for } \\
\text { managing and monitoring risks; and to maintain systems and standards for measurement of } \\
\text { risk and return, reporting and internal control. Through on-site supervision FI seeks to } \\
\text { examine the senior management's understanding of market risks inherent in business } \\
\text { lines/products traded as well as senior management's understanding of implications of the } \\
\text { risk management information. } \\
\text { Section } 11 \text { of the guideline stipulates that reports to the Board of Directors and the } \\
\text { managing director should at least cover risk exposures, limit utilization, returns, results of } \\
\text { stress test and back-testing etc. FI examines the quality of management information through } \\
\text { the on-site supervision process and also reviews the assumptions used in stress tests } \\
\text { scenarios. } \\
\text { At present no Swedish bank has authorization to use the Internal Models Approach for } \\
\text { market risk capital requirements. Two banks have applied for an authorization and FI is } \\
\text { currently in the process of evaluating the models. It is FI's judgment is that it has the } \\
\text { adequate knowledge and skills to evaluate and follow up these models. }\end{array}$ \\
\hline Assessment & Compliant \\
\hline Comments & None. \\
\hline Principle 13. & $\begin{array}{l}\text { Other Risks } \\
\text { Banking supervisors must be satisfied that banks have in place a comprehensive risk } \\
\text { management process (including appropriate board and senior management oversight) to } \\
\text { identify, measure, monitor, and control all other material risks and, where appropriate, to } \\
\text { hold capital against these risks. }\end{array}$ \\
\hline Description & $\begin{array}{l}\text { The responsibility of the board and the management of a company are governed by the } \\
\text { Companies Act Chapter } 8 \text { where it is stipulated that it is the responsibility of the board to } \\
\text { make sure that the company is organized in such a way that accounting, management of } \\
\text { assets and other financial conditions are be controlled in a safe manner. According to the } \\
\text { general guideline regarding control, internal information and internal controls the board } \\
\text { shall make sure that the institution has an organization that is appropriate; inter alia the } \\
\text { functionality of the institution's regulations, systems and procedures in the areas of risk } \\
\text { control, monitoring and follow-up on risks. The following risks are mentioned in the } \\
\text { general guidelines; credit and counterpart risks, market risks, liquidity risks, IT and other } \\
\text { technical risks, administrative risks and legal risks. } \\
\text { General guidelines related to specific risk areas are the those issued on credit risks } \\
\text { (FFFS 1995:49) and market-and liquidity risks (FFFS 2000:10). FI has issued regulation } \\
\text { (FFFS 1998:11)on the reporting of interest risk exposures. Through on-site investigations, } \\
\text { FI can form an opinion of to what extent the institutions have implemented the general } \\
\text { guidelines. FI has drafted internal guidelines used for assessing the different risk areas. } \\
\text { The Act on Capital Adequacy and Large Exposures regulates that the minimum }\end{array}$ \\
\hline
\end{tabular}




\begin{tabular}{|c|c|}
\hline & $\begin{array}{l}\text { requirement of capital to risk-weighted assets is } 8 \text { percent for all credit institutions. FI does } \\
\text { not have a mandate to prescribe a higher rate of capital coverage. Section 44a of the general } \\
\text { guideline on Annual reports in credit institutions and securities companies (FFFS 2000:18) } \\
\text { prescribes that the institution has to give an account of the exposures related to financial } \\
\text { and other risks, for example operational and legal risks. The institutions do not report to } \\
\text { what extent they carry out foreign liquidity transactions and nor the volume of the } \\
\text { transactions. In examinations and through the provisions of the general guideline on } \\
\text { market-and liquidity risks (FFFS 2000:10) FI addresses the question of currency risks in } \\
\text { the management of a bank. }\end{array}$ \\
\hline Assessment & Largely Compliant \\
\hline Comments & $\begin{array}{l}\text { FI has issued general guidelines on management of market risk and internal controls. FI has } \\
\text { no supervisory standards on exchange and operational risk. FI is in the process of giving } \\
\text { reporting guidelines concerning liquidity. FI has no powers to require a bank to hold capital } \\
\text { against risks other than market and credit risk. }\end{array}$ \\
\hline Principle 14. & $\begin{array}{l}\text { Internal Control and Audit } \\
\text { Banking supervisors must determine that banks have in place internal controls that are } \\
\text { adequate for the nature and scale of their business. These should include clear arrangements } \\
\text { for delegating authority and responsibility; separation of the functions that involve } \\
\text { committing the bank, paying away its funds, and accounting for its assets and liabilities; } \\
\text { reconciliation of these processes; safeguarding its assets; and appropriate independent } \\
\text { internal or external audit and compliance functions to test adherence to these controls, as } \\
\text { well as applicable laws and regulations. }\end{array}$ \\
\hline \multirow[t]{3}{*}{ Description } & $\begin{array}{l}\text { The Companies Act Chapter } 8 \text { determines the responsibilities of the Board of Directors } \\
\text { concerning organization and administration. The board is responsible for the company's } \\
\text { organization and it has to see to that administrative affairs are properly arranged. } \\
\text { Particularly, monitoring of the company's accounts, the bank's treasury, and the general } \\
\text { economic performance belong to the board. The board shall issue written instructions on the } \\
\text { frequency and the type of reporting that is to be delivered to the board. The Act also } \\
\text { provides that the responsibilities of the Board of Directors concerning division of duties } \\
\text { shall be determined in a working plan. FI's general guideline concerning control, internal } \\
\text { information and internal controls (FFFS 1999:12) determines that it is the board that is } \\
\text { responsible for having reliable procedures and information systems in place, in order to } \\
\text { maintain internal control but also in order to analyze and evaluate risks. The general } \\
\text { guidelines concerning credit risks (FFFS 1995:49) and general guidelines concerning } \\
\text { preventive measures of crimes (FFFS 1996:8) also emphasize the importance of internal } \\
\text { controls and the responsibility of the board. }\end{array}$ \\
\hline & $\begin{array}{l}\text { FI's guideline 1999:12 states that the board must see to that risk monitoring is arranged in a } \\
\text { satisfactory manner. In addition to general guidelines for risk management there must be } \\
\text { special instructions for managing and controlling of risks inter alia in the following risk } \\
\text { areas: credit and counterparty risk, interest rate, foreign exchange and liquidity risk, IT and } \\
\text { other operational risks, and administrative and legal risks. Internal control systems must be } \\
\text { built so as to assure correct and complete accounting. Control routines must be established } \\
\text { that provide information of deviations from internal guidelines. Security risk pertaining to } \\
\text { proprietary information and physical controls must be arranged; IT security must be } \\
\text { safeguarded to enable the bank to continue its operations uninterrupted. Sharing of duties } \\
\text { and responsibilities must be arranged in a manner that prevents a single person from } \\
\text { making independent decisions without outside scrutiny (four eyes principle). }\end{array}$ \\
\hline & $\begin{array}{l}\text { The general guideline concerning reports about appointed members of the boards of } \\
\text { directors and the senior management (FFFS 1998:13-14) determines that FI has to be } \\
\text { provided with information about the members of management. FI has the legal authority to } \\
\text { require changes in the composition of the board and management only in connection with }\end{array}$ \\
\hline
\end{tabular}




\begin{tabular}{|c|c|}
\hline & $\begin{array}{l}\text { an application for banking license. FI does not continuously carry out any investigations in } \\
\text { order to make sure that the competence of directors or senior management is satisfactory. } \\
\text { As part of on-site inspections, especially concerning internal control systems, FI determines } \\
\text { that there is an appropriate balance in the skills and resources between control functions and } \\
\text { operative functions. } \\
\text { The general guideline FFFS 1999:12 states that all credit institutions shall have an } \\
\text { independent audit function. Independent of operative functions, the audit must be } \\
\text { subordinated directly to the board or the managing director. In all cases, internal auditors } \\
\text { must report to the board. The board shall issue instructions to internal audit as to its duties } \\
\text { and reporting procedures. As a part of on-site inspections, especially concerning systems of } \\
\text { internal controls, FI examines whether the internal audit function has appropriate } \\
\text { independence, sufficient resources, and has the authority to carry through all investigations } \\
\text { and to obtain all information that its required to discharge its duties. FI also examines that } \\
\text { there are audit plans, work routines and reporting lines in place. By the Swedish banking } \\
\text { act FI has the authority to obtain all information that is needed for the supervision. In } \\
\text { connection with on-site inspections FI requires reports of the audit function for its perusal. } \\
\text { In Section } 6 \text { of the general guideline (FFFS 1999:12) it is stated that unless otherwise } \\
\text { stipulated information must be reported to FI in the form it is available through the bank's } \\
\text { internal communication system. } \\
\text { It is customary that board members are non-executives representing different backgrounds, } \\
\text { inter alia major owners of banks. }\end{array}$ \\
\hline Assessment & Largely Compliant \\
\hline Comments & $\begin{array}{l}\text { FI is not empowered to require a change in the constitution of a board due to shortcomings } \\
\text { in the skills and knowledge of board members. }\end{array}$ \\
\hline Principle 15. & $\begin{array}{l}\text { Money Laundering } \\
\text { Banking supervisors must determine that banks have adequate policies, practices, and } \\
\text { procedures in place, including strict "know-your-customer" rules, that promote high ethical } \\
\text { and professional standards in the financial sector and prevent the bank being used, } \\
\text { intentionally or unintentionally, by criminal elements. }\end{array}$ \\
\hline Description & $\begin{array}{l}\text { The legal framework for anti-money laundering is provided in the Banking Business Act } \\
\text { and the Act on Measures against Money Laundering. Regulations and general guidelines } \\
\text { issued by FI which set out requirements on banks regarding inter alia high ethical standards, } \\
\text { crime prevention and measures to hinder money laundering are mainly the following:) } \\
\text { regulation concerning measures for the prevention of money laundering (FFFS 1999:8), } \\
\text { regulation on crime prevention in banking (FFFS 1996:8), guidelines on principles for } \\
\text { dealing with ethical issues in institutions under supervision (FFFS 1998:22), guidelines } \\
\text { concerning management, internal information and internal controls (FFFS 1999:12), } \\
\text { guidelines concerning reporting of incidents of high importance (FFFS 1999:7). } \\
\text { The Act and the regulation on the prevention of money laundering pose requirements to } \\
\text { banks regarding policies and instructions for customer identification and record keeping. } \\
\text { Identity is to be checked on the commencement of a business relationship. Checks are to be } \\
\text { made whenever a transaction exceeds SKR 110,000. Banks licensed in another EEA } \\
\text { country are exempt from the rule. If there are grounds for assuming that the party is not } \\
\text { acting on his own behalf, steps have to be taken to establish the identity of the originating } \\
\text { party. A check shall always be made if there are reasons to suspect a case of money } \\
\text { laundering. Documents relating to a transaction are to be kept for five years after the } \\
\text { business relationship came to an end. FI's regulation requires banks to have an internal } \\
\text { register that can be used by administrating officers as a source of customer information. } \\
\text { FI's regulation states that the scrutiny of transactions should follow the same principles }\end{array}$ \\
\hline
\end{tabular}


regardless of the fashion a transaction has been initiated. Special vigilance should be observed when scrutinizing transactions with countries where there are difficulties in obtaining information or whose legal system for combating money laundering have serious deficiencies.

Sweden participates in the FATF exercise on Non cooperative Countries or Territories, NCCT. Institutions are required to conduct intensified due diligence when dealing with such countries. The FATF "black list" has been submitted to all institutions covered by the Act.

FI's regulation (Section 3) states that it is mandatory to appoint a person with explicit responsibility for ensuring that all relevant anti-money laundering measures (control systems, work routines, reporting procedures, training programs) are implemented and in accordance with legislation, regulations and instructions. The compliance officer must be a member of management.

The regulation states that the board or executive management for the bank shall provide instructions on, e.g., the decision making and reporting procedures for suspicious transactions. There are to be checklists and manuals to provide indications of money laundering. Feedback must be given to the originating entity within the bank on whether notification to the FIU (Financial Intelligence Unit) of police has been made. It is recommended that decisions regarding reporting a suspicious transaction to the FIU should be taken in a centralized manner.

The bank's appointed central compliance officer has the responsibility for the implementation and good functioning of the reporting duties. On a daily basis the function often is often delegated to a security unit as part of the tasks that are undertaken by the bank's security organization. FI does not require the foreign branches of banks to report cases of suspected money laundering. However, according to Section 7 of FI's guidelines on money laundering, banks should report to FI of cases where local regulations prevent the bank from applying its anti-money laundering policy consistently on a global basis.

In the guidelines on incident reporting (FFFS 1999:7) there is a list of incidents including suspicions of internal or external crime which are expected to be reported to FI if the incident is on a level of considerable (negative) importance. There is also the broader reporting duty of the external auditors (the BCCI-directive) which is applicable to crime. External auditors' reporting duties involve under certain conditions a wide range of suspected crimes including money laundering in accordance with the Companies act (Chapter 10 sections 38-40). The suspected crimes shall be addressed to the prosecutor's office, but if a bank is involved FI is expected to be notified as well.

In the Act on Measures against Money laundering it is stated that bank staff can not be held liable for the reporting of suspicious transactions done in good faith (Section 10). FI conducts both on-site and off-site inspections with the aim to check the compliance of antimoney laundering measures in banks. On-site inspections are conducted in the context of general inspections or with a focus explicitly on anti-money laundering measures and crime prevention/protection. FI has conducted within a year five inspections of anti-money laundering practices in banks; no major shortcomings or grievances have been detected. As a part of the manual for operational risk, the supervisor has drawn up internal guidelines examinations of anti-money laundering practices.

Regarding the enforcement powers FI can revert to the measures enumerated under CP 22. Intentional or gross negligent failure to comply with some essential requirements of the Act on Measures against Money Laundering is a criminal offence and punishable with a fine 
(the Act Section 14).

The secrecy Act, Chapter 1 Section 3, limits the extent to which information, which is subject to confidentiality, may be shared with a foreign financial regulator. It also depends on whether criminal proceedings have been initiated or not. FI has entered into MOUs with a number of foreign regulators, where are set out the procedures for information sharing. In the guidelines FFFS 1988:22 there are given recommendations on ethics policies that should cover in detail how to deal with ethical policy issues.

Sweden is a member of the Financial Action Task Force and has endorsed and implemented the FATF 40 recommendations. A self assessment exercise done in 2001 shows that Sweden is in full compliance with 26 of the 28 mandatory recommendations. The shortcomings are related to the missing fit and proper tests of new staff involved with antimoney laundering measures and the fact that foreign exchange offices and money transmitting firms are not subject to FI's supervision.

Section 10 of the regulation (FFFS 1999:8) requires banks to have an ongoing training program on matters concerning money laundering. All employees handling matters concerning the Anti Money Laundering Act shall be kept continuously informed of current developments of the field.

If FI learns of transactions which may be deemed to point to money laundering it must inform the FIU of the matter. FI is able to share information with the relevant judicial authorities on the conditions outlined in the Secrecy Act (1980:100).

\begin{tabular}{|c|c|}
\hline Assessment & Compliant \\
\hline Comments & $\begin{array}{l}\text { The relevant laws and regulations provide the legal and institutional framework for } \\
\text { combating money laundering. To supervise the compliance of the laws and to assess } \\
\text { efficiency of the measures, in addition to its own examinations, the supervisor relies to a } \\
\text { large extent on the work by internal auditors and the information provided by the external } \\
\text { auditors appointed by FI. }\end{array}$ \\
\hline Principle 16. & $\begin{array}{l}\text { On-Site and Off-Site Supervision } \\
\text { An effective banking supervisory system should consist of some form of both on-site and } \\
\text { off-site supervision. }\end{array}$ \\
\hline Description & $\begin{array}{l}\text { Supervision is performed as a combination of off-site supervision and on-site supervision. } \\
\text { There are also various supervisory approaches ranging from specialized risk analysis to } \\
\text { general supervisory activities. By on-site supervision, supervisors verify that internal } \\
\text { control systems are in place, risk management methods are sufficient, etc. FI has issued } \\
\text { guidance in various areas, which is followed up by on-site supervision. To support } \\
\text { supervisors in their examinations and enhance quality, handbooks have been issued on } \\
\text { credit risk, market risk, liquidity risk, internal controls, and operational risk. FI appoints } \\
\text { auditors to banks who are required to report on compliance in key risk areas, i.e.,. on major } \\
\text { deviations from FI's regulations and guidelines. Internal control systems are to be a key } \\
\text { subject for the auditors appointed by FI, especially how the reporting systems safeguard the } \\
\text { supervisor receiving accurate information and in compliance with laws and regulations } \\
\text { (Chapter } 7 \text { Section } 5 \text { the Banking Business Act). } \\
\text { Prudential reports and statistical returns are analyzed on a regular basis (quarterly, semi- } \\
\text { annually months and annually). Reported data from all financial institutions is fed into a } \\
\text { specific database (Värdetatabasen). There are internal routines for ensuring that } \\
\text { supervisors' and risk analysts' attention is drawn to deviations in data regarding capital } \\
\text { adequacy (also to down-going trends) and large exposures. This information will then be } \\
\text { subject to further risk analysis and examination. }\end{array}$ \\
\hline
\end{tabular}


In addition to the general analysis of prudential reports, risk analysts have access to the database (Värdetatabasen), where the relevant background analysis data can be found. The database is a base for in-depth risk analyzes on various risk areas. Risk analysts also carry out on-site examinations in order to obtain other necessary information for the analysis.

The overall supervisory principles and interaction between the main processes (supervision, financial stability analysis, and regulating and licensing) have been described in an internal paper by FI of March 2000 titled "The New Financial Supervision" (Den nya tillsynen). A detailed description of the supervision process has been made in the document "The Supervision Process" (Tillsynsprocessen) dated in February 2001. The supervision process depends on input from the other main processes. The horizontal cooperation between the main organizational departments (banking, insurance and capital markets) is to be enhanced by the contribution of "group managers" (koncernansvariga) who are responsible for making a risk assessment of the major systemically important groups or entities. The inspections and off-site analyzes of banks are done with the participation of specialists from the different sectional departments and the functional entities within them (risk analysis, legal issues and supervision), as well as from the recently established department for strategy and analysis. The department for strategy and analysis is responsible analyzing the prudential reports from all of the supervised entities, as well as for producing statistical information and, inter alia, for drafting the yearly financial stability report of FI.

The group wide risk assessment (riskbedömning) has been defined as the core product of the supervisory process. The assessment is to embrace, inter alia, stress testing, risk diversification, pricing of risk, ownership structure, corporate governance, and capital adequacy. The content and methods of the assessment are yet to be defined in a systematic way. The process will be implemented in the final form in the year 2002. Each of the 13 groups or entities with systemic importance are to be evaluated on a yearly basis. One of the large commercial banks will subject to the first assessment of the prototype of the new model.

The supervisory entity within the credit market department is responsible for planning the supervisory process for each banking group. There are three categories of supervisors: general analysts, who analyze prudential reports regularly; specialized risk analysts, who do in-depth analyzes in various risk areas as well as on-site examinations and general supervisors for respective financial sector, whose main task is to carry out on-site examinations.

The annual supervision plan is updated every four months. Input to the review comes from a general directive document by the Director General, from results from analyzes, from previous supervision documents, etc. The mix of on-site and off-site supervision may differ between financial groups and companies. The total number of financial institutions and companies subject to supervision amounts to more than 2000. Among them are a number of medium size and small institutions such as savings banks, insurance brokers, small securities firms and very small local insurance companies and others. The frequency of onsite examination is higher with regard to large financial groups and companies. Small companies depend on off-site analyzes to a much higher degree. Sometimes, individual occurrences may give reason for on-site examinations also in small companies. Each such occurrence is, however, evaluated from a risk- and essentiality aspect, in order to determine if an examination should be prioritized.

An external consulting agency has been hired to perform quality control on the effectiveness of the risk assessment process. Handbooks on supervisory routines for examiners have been drafted on different subject areas, and the supervisory "products" as 


\begin{tabular}{|c|c|}
\hline & $\begin{array}{l}\text { defined above have been given definitions. A specified process leader has to make random } \\
\text { tests, e.g., of inspection reports to check verify compliance with written procedures. } \\
\text { Deviations from internal rules are reported to the owner of the supervision process (chief of } \\
\text { department for strategy and analysis). External auditors of the Swedish National Audit } \\
\text { Office also make checks on how the supervisor has been able to fulfill its objectives. } \\
\text { FI's supervisors are entitled to get any documentation from the supervised entity, including } \\
\text { reports from internal and external auditors. FI appoints auditors in banks in addition to the } \\
\text { auditors appointed at banks' general meetings. The auditors are subject to specific reporting } \\
\text { requirements to FI. } \\
\text { The risk analysis units at FI specialize on assessing risks in various areas, e.g., credit risk, } \\
\text { market risk, liquidity risk and operational risk. The supervisory approach to risk is to look } \\
\text { at control environment and routines, risk management, risk measurement (costs for } \\
\text { controlling risks, costs for failures, etc.), risk modeling, and pricing and capital allocation to } \\
\text { risk. } \\
\text { The basic principle in public administration is that documents and information are publicly } \\
\text { available. There are, however, secrecy laws, which strictly protects certain information e.g., } \\
\text { business relations or information that could damage the company if it was made public. } \\
\text { FI has in its guidance (FFFS 1999:12) stated what should be required of internal audit } \\
\text { functions regarding independence, competence, and reporting procedures. It is part of the } \\
\text { supervisory process to assess compliance with this requirement. Supervisors usually meet } \\
\text { with the internal auditors when carrying out on-site inspections. }\end{array}$ \\
\hline Assessment & Compliant \\
\hline Comments & $\begin{array}{l}\text { FI has a supervision process with defined procedures and responsibilities with on-site and } \\
\text { off-site supervision. Due to the newness of the supervision process, some parts of the model } \\
\text { for group wide risk assessment have not yet been fully tested. The model is projected to be } \\
\text { implemented during } 2002 \text {. }\end{array}$ \\
\hline Principle 17. & $\begin{array}{l}\text { Bank Management Contact } \\
\text { Banking supervisors must have regular contact with bank management and a thorough } \\
\text { understanding of the institution's operations. }\end{array}$ \\
\hline Description & $\begin{array}{l}\text { The management of FI has regular meetings, on a quarterly basis, with senior management } \\
\text { from the four biggest banks in Sweden. There are also yearly meetings where the annual } \\
\text { accounts and other specific issues are discussed with the four banks as well as with some of } \\
\text { the other banks. The boards and the management of Swedish banks have a tradition of } \\
\text { informally notifying FI whenever changes, structural, strategic etc, are about to take place. } \\
\text { The Banking Business Act and the Financing Operations Act require a bank to notify, and } \\
\text { in some circumstances also apply for new permit concerning their business activities, e.g., } \\
\text { major acquisitions, as well changes in ownership. According to FI guideline (1999:7) } \\
\text { incidents that are of major importance to the bank must be reported to FI. This includes } \\
\text { crimes against the bank and deliberate as well unintentional mistakes connected to banking } \\
\text { activities. Essential economic losses must be connected to such incidents; they must pose a } \\
\text { threat to the bank's vital functions, incidents can or may have lead to serious disruptions, } \\
\text { recurring or long cuts in the bank's services, communications or IT activities; there may be } \\
\text { a risk that the bank's integrity is jeopardized, or several customers or employees are } \\
\text { affected. } \\
\text { There is a specific general guideline concerning Assessment of Owner/Management } \\
\text { (FFFS 1998:14). The persons who are examined are new board members, deputy board } \\
\text { members, managing directors and deputy managing directors. The controls consists of }\end{array}$ \\
\hline
\end{tabular}




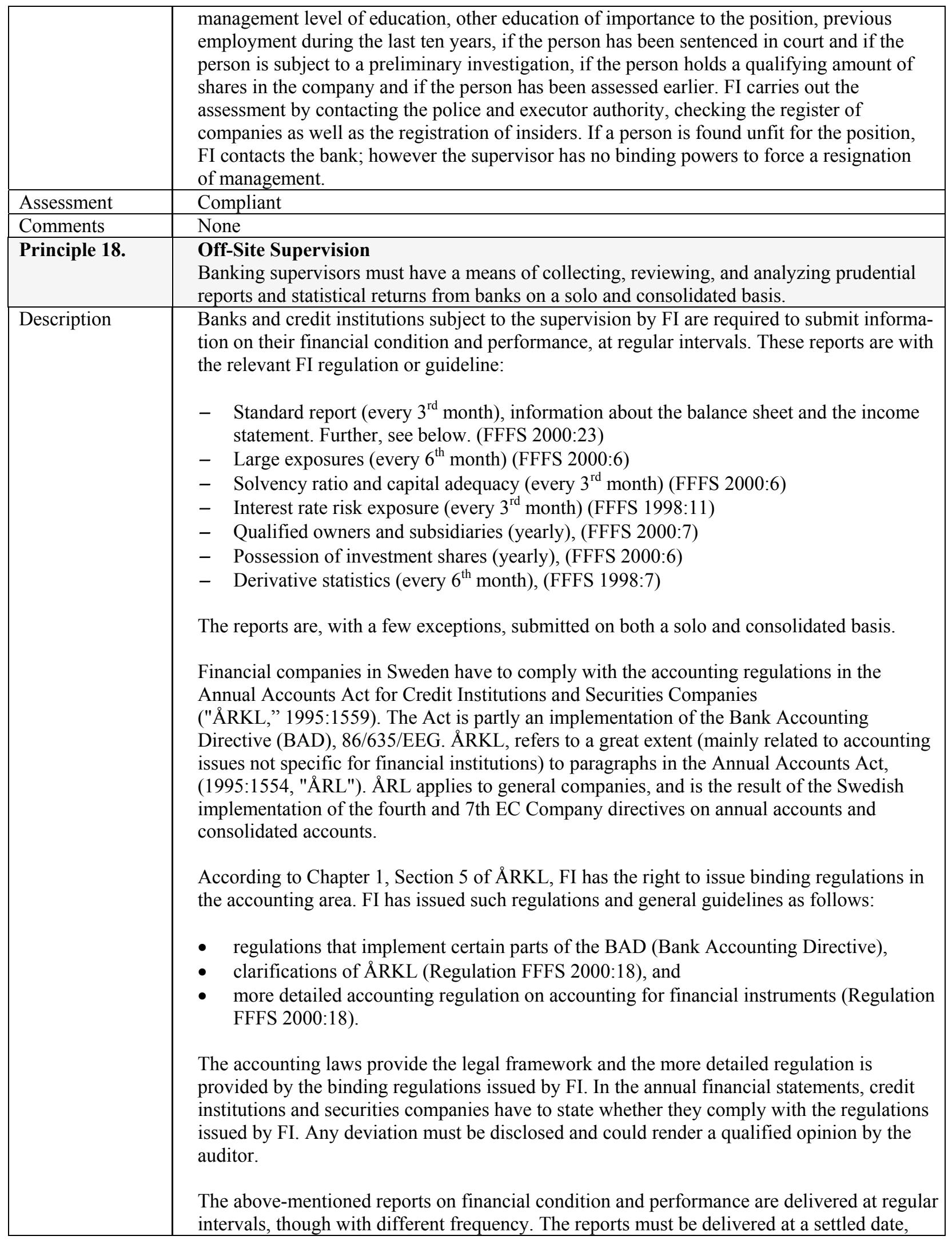




\begin{tabular}{|c|c|}
\hline & 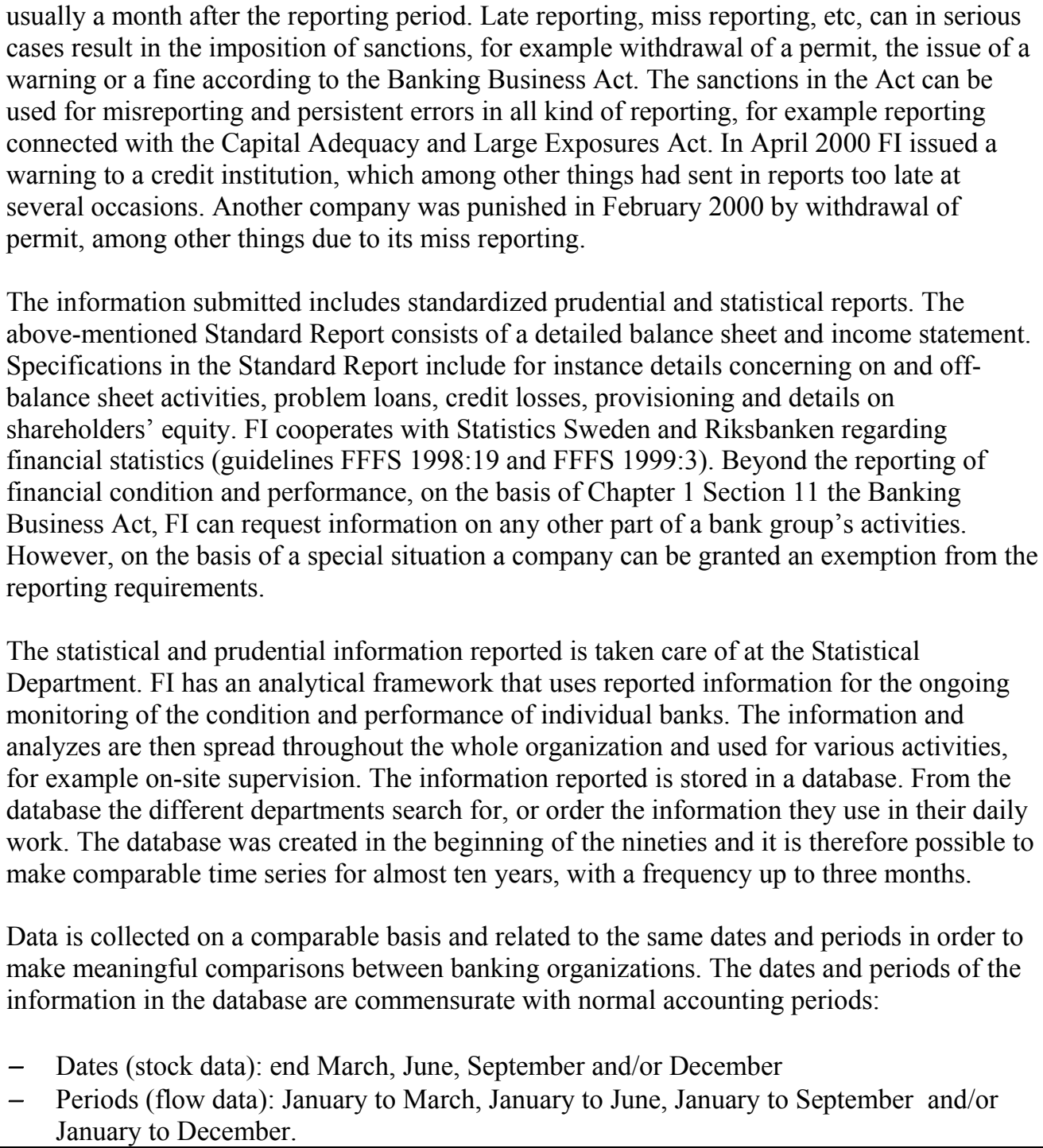 \\
\hline Assessment & Compliant \\
\hline Comments & $\begin{array}{l}\text { There is no standardized prudential report regarding a credit institution's liquidity situation; } \\
\text { one is scheduled to come in place during } 2002 .\end{array}$ \\
\hline Principle 19. & $\begin{array}{l}\text { Validation of Supervisory Information } \\
\text { Banking supervisors must have a means of independent validation of supervisory } \\
\text { information either through on-site examinations or use of external auditors. }\end{array}$ \\
\hline Description & $\begin{array}{l}\text { By on-site supervision, FI endeavors to form a coherent picture of an institution's risk } \\
\text { position. Supervisors verify that internal control systems are in place, risk management } \\
\text { methods are sufficient and that laws and regulations are complied with. To support } \\
\text { supervisors in their examinations and enhance quality, handbooks have been issued } \\
\text { different risk areas. On-site supervision is performed according to a yearly plan that is } \\
\text { updated three times a year. An examination must be concluded with a written supervision } \\
\text { report. The report must include e.g., a description of shortcomings detected and a remark or } \\
\text { admonition to rectify the situation. On-site examinations at the large banks generally } \\
\text { require the contribution of three inspectors for three days each. The total time spent on an } \\
\text { individual inspection is two to three months. FI performs inspections of the major risk areas } \\
\text { in the larger banks with a frequency of every three years. The most important foreign }\end{array}$ \\
\hline
\end{tabular}




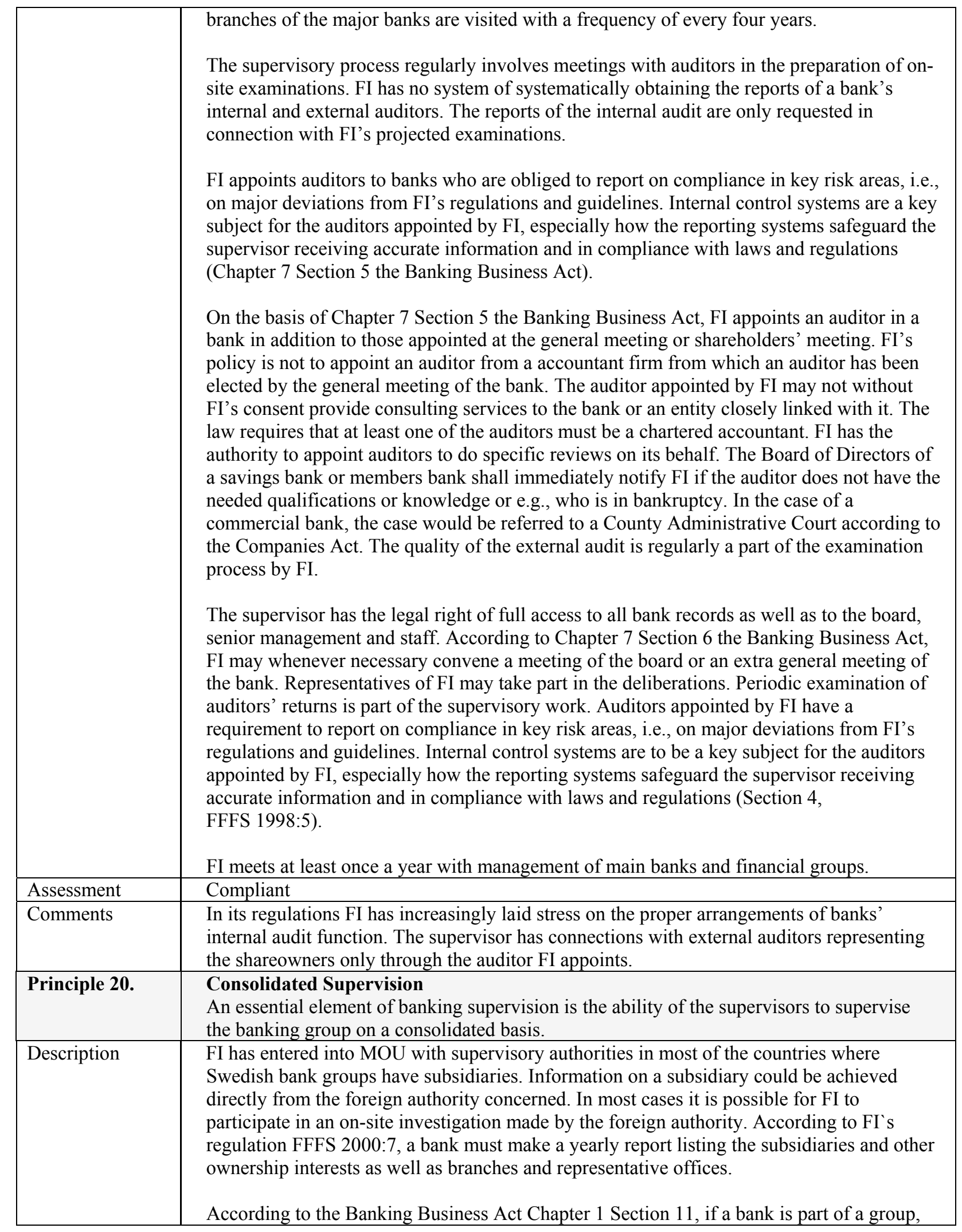


the provisions of the Act and the Capital Adequacy and Large Exposures Act regarding the bank's business and supervision of the bank shall apply, where applicable, to other companies within the group, including non-financial companies. The limitations imposed on the bank's business shall also relate to the same companies jointly. Other entities belonging to the group shall provide FI with any information regarding their operations and relevant circumstances which FI requires in order to exercise its supervision of the bank. Group contributions may only be given by the bank following the consent of FI.

According to the Banking Business Act Chapter 7 Section 1, a bank is subject to the supervision of FI and must be registered with FI. The bank must furnish FI with any information regarding its operations and circumstances connected therewith requested by FI. FI may carry out investigations at the bank at any time it considers necessary. If a Swedish bank has taken a decision which is in contravention of the Act or any other legislation which regulates the bank's operations, or against a regulation issued by virtue of such legislation or against the bank's articles of association, FI may enjoin the execution of the decision. If possible, FI may order the bank to rescind the decision if it has already been executed.

FI is in the process of developing a new model for risk assessment of the financial institutes under supervision based on three parts: key financial ratios based on information from the institutes; market ratios for the public institutes; and risk analysis and evaluation of risk management and controls based on FI's own findings through examinations. It is FI's goal to perform the full risk assessment on thirteen institutes or groups of institutes that FI has identified as systemically critical.

FI is currently in the process of developing a new approach to the financial strength and risk exposure of supervised institutes. The supervision of bank groups on a consolidated basis is of the highest priority for FI. FI is responsible for the regulations concerning accounting standards for credit institutes and financial conglomerates/financial groups. Accounting regulations apply to both solo level and consolidated groups.

In the Capital Adequacy and Large Exposures Act Chapter 6 there is a definition for a financial group. The group includes a credit institution, a securities firm or a financial holding company with subsidiaries that are either credit institutions, securities firms or "financial institutions" (holding companies, securities firms without licenses or currency traders). According to the Capital Adequacy and Large Exposure Act, the prudential rules contained in the law are applied both on a solo level for credit institutions (and securities firms) and on a consolidated basis concerning the financial group. Also companies that provide data services or manage real estate are included in the financial group.

FI collects a number of reports regarding parent companies, Swedish subsidiaries, foreign branches and consolidated reports for groups with a bank or a holding company at the top. The reports cover data, e.g., on the balance sheet and the profit and loss accounts, on large exposures and capital adequacy ratios regarding credit and market risks (FFFS regulation 2000:6). Collection of data and analyzes are done both on solo and consolidated basis. The reporting requirements are applied to all institutions on a uniform basis.

FI does not have powers to circumscribe the range of activities a bank is entitled to engage in on the basis of the bank's risk position, inter alia explicit powers to order a foreign branch to be shut down. A bank does need FI's authorization for acquiring a subsidiary, i.e., a bank's business. FI does not accord sufficient attention to the issue of efficient host country supervision when processing applications for foreign establishments by local banks. (cf. CP 23).

If a bank is part of a group, the legal provisions regarding the bank's business and 


\begin{tabular}{|c|c|}
\hline & $\begin{array}{l}\text { supervision of the bank also apply to other undertakings within the group. The limitations } \\
\text { imposed on the bank's business shall relate to the undertakings jointly. Other entities } \\
\text { belonging to the group shall provide FI with any information regarding their operations that } \\
\text { FI requires in order to exercise its supervision of the bank. If a bank has made a decision in } \\
\text { contravention of a banking act, FI may enjoin the execution of the decision. } \\
\text { The fit and proper tests of the owners of banks are carried out according to FI's regulations } \\
\text { on the basis of Chapter } 7 \text { Section } 13 \text { a the Banking Business Act. }\end{array}$ \\
\hline Assessment & Largely Compliant \\
\hline Comments & $\begin{array}{l}\text { The laws apply to prudential regulation on a consolidated basis; the regulations give the } \\
\text { supervisor powers to give prudential rules on a consolidated basis. FI does not, however, } \\
\text { have powers to circumscribe the range of activities a bank can engage in, e.g., through its } \\
\text { subsidiaries. When assessing an application for a foreign establishment by a Swedish bank } \\
\text { FI is not required by law to assess the supervisory arrangements in the host country in } \\
\text { order to safeguard efficient supervision on a consolidated basis. In view of the expanding } \\
\text { overseas activities of Swedish banks, FI ought to enhance the assessment of the safety and } \\
\text { soundness of the banks' foreign operations. The authority has yet to conclude agreements } \\
\text { with some of the countries outside the EU where Swedish banks have established } \\
\text { operations. In the case of complex multinational banking groups FI is in the process of } \\
\text { defining its role as the lead supervisor. }\end{array}$ \\
\hline Principle 21. & $\begin{array}{l}\text { Accounting Standards } \\
\text { Banking supervisors must be satisfied that each bank maintains adequate records drawn } \\
\text { up in accordance with consistent accounting policies and practices that enable the } \\
\text { supervisor to obtain a true and fair view of the financial condition of the bank and the } \\
\text { profitability of its business, and that the bank publishes on a regular basis financial } \\
\text { statements that fairly reflect its condition. }\end{array}$ \\
\hline Description & $\begin{array}{l}\text { The general guideline concerning control, internal information and internal controls by FI } \\
\text { (FFFS 1999:12) determines that it is the board of the institution which is responsible that } \\
\text { there be reliable procedures and information systems within the institution in order to } \\
\text { maintain internal control but also in order to analyze and evaluate risks. The regulations and } \\
\text { general guideline concerning the annual reports of banks (FFFS 2000:18) determine what is } \\
\text { required concerning financial record keeping system and the data they should produce, to } \\
\text { the public as well as to FI. } \\
\text { Should an institution have failed to publish an annual report or/and the annual report has } \\
\text { not been audited properly FI would be in a position to revoke the license. The annual report } \\
\text { has to be audited as prescribed in law. According to the Annual accounts Act and the } \\
\text { Swedish Companies Act it constitutes a crime not to publish an audited annual report. If the } \\
\text { bank does not deliver an annual and audited report within eleven months since the ending } \\
\text { of the financial year the bank will be compulsorily liquidated. The auditors' tasks are } \\
\text { defined in the Swedish Companies Act Chapter } 10 \text { sections 3-6. The auditor examines the } \\
\text { annual report and the accounting records as well as the administration of the Board of } \\
\text { Directors and the managing director. The audit report attached to the annual accounts must } \\
\text { be signed by all auditors, including the one appointed by FI. } \\
\text { The auditors appointed by the general meeting of the shareholders and the auditor } \\
\text { appointed by FI are responsible for the examination of the accounting records. The auditor } \\
\text { appointed by FI files a report according to the general guideline FFFS 1998:5. The auditor } \\
\text { has to make a report within three weeks of completing the auditing of the annual accounts. } \\
\text { Among others it must include notes on major shortcomings in the bank's internal control } \\
\text { systems, accounting and administration, as well as an account of on discrepancies from FI's } \\
\text { regulations and guidelines. }\end{array}$ \\
\hline
\end{tabular}


FI has issued regulation concerning the annual reports of banks (FFFS 2000:18). Banks also have to follow the Annual accounts Act of credit institutions and securities companies where are implemented the EU's Bank Accounts Directive. Banks are bound to follow the above and to follow other laws and applying recommendations and statements on accounting matters from other standard setters where appropriate. Banks are required to utilize valuations rules that are consistent, realistic and prudent, taking account of current values where relevant, and that profits are net of appropriate provisions.

The Swedish Companies Act and the Annual accounts Act of credit institutions and securities companies as well as the regulations concerning annual reports of banks (FFFS 2000:18), inclusive minimum standards of public disclosure requirements, as well as FI's guideline 1998:5 for auditors appointed by FI, provide the general framework. But also the recommendations from the Swedish Institute of Authorized Public Accountants (FAR) determine generally accepted auditing standards. The auditors' reports are not subjected to FI's approval prior to publishing.

In the Secrecy Act, there are provisions on what type of information is to be treated as confidential and to which authorities and other bodies such information can be divulged to.

Swedish banks have to produce annual audited financial statements according to the Annual accounts Act of credit institutions and securities companies. The Swedish Companies Act requires that the auditor examine the company's annual report and the accounting records as well as the administration of the Board of Directors and the managing director. The examination should be performed in accordance with generally accepted auditing standards. The Swedish Institute of Authorized Public Accountants determines generally accepted auditing standards. The standards comply substantially with internationally accepted auditing standards.

FI is required by law (Chapter 7 Section 5 Banking Business Act) to appoint additional auditors to perform the same examination as the auditors appointed by the general meeting of the shareholders. Auditors appointed by FI examine issues according to instructions from the supervisory authority. The auditor appointed by FI may not represent the same auditing firm as the auditor appointed by the bank's general meeting.

Furthermore banks are to follow the Bookkeeping Act that contains regulations on bookkeeping and retaining of accounting records. The banks should follow the recommendations issued by the Swedish Accounting Standards Board (Bokföringsnämnden), which was founded to interpret the Bookkeeping Act as well as generally accepted accounting principles as stipulated by the Act. Where appropriate, banks should also apply the recommendations and statements on accounting matters from the Swedish Financial Accounting Standards Council (Redovisningsrådet), which is the body in Sweden assigned to implement the accounting standards issued by the International Accounting Standards Council, IASC. The work is under progress and so far about 20 recommendations have been issued.

FI has no powers to revoke the auditors appointed by the general meeting of shareholders. FI can instead revoke the appointment of the auditor referred in Chapter 7 Section 5 the Banking Business Act. FI conducts its supervision both with its own examination staff as well as external auditors, including the one appointed by it according to the Banking Business Act.

Banks have to produce interim statements at least once a year according to the Annual Accounts Act of credit institutions and securities companies. The law states also the minimum requirements of what the interim statement should include and when the interim 


\begin{tabular}{|c|c|}
\hline & $\begin{array}{l}\text { statements should be issued. FI's regulations and general guidelines (FFFS 2000:18) } \\
\text { provide further details on fundamental regulations, rules on valuation and disclosures to be } \\
\text { applied when preparing the interim statement. The banks that are listed on the stock } \\
\text { exchange are to prepare interim statements quarterly. } \\
\text { The auditor has to report immediately to FI if he becomes aware of circumstances which } \\
\text { may constitute a significant breach of the legislation which regulates the operations of } \\
\text { banks; may have a negative effect upon the bank's future operations; or may lead to the } \\
\text { auditor advising against the adoption of the balance sheet or profit and loss account or to } \\
\text { qualification in accordance with the Companies Act. The auditor must similarly report to FI } \\
\text { of any of his findings that concern the bank's parent undertaking or subsidiaries, or an } \\
\text { undertaking which has a similar relation to the bank. The reporting requirements of the } \\
\text { auditor appointed by FI are stipulated in FI's guideline (FFFS 1998:5). FI has also issued a } \\
\text { general guideline concerning reporting of significant events (FFFS 1999:7) according to } \\
\text { which the management of the bank has to file a report to the supervisor within a period of } \\
\text { four weeks. } \\
\text { The guideline 1998:5 states also that the auditor appointed by FI shall on a continuous basis } \\
\text { report to FI on such findings that may be of significance to FI for its supervisory purposes. } \\
\text { The auditor must also report to FI of any written complaint addressed to the board of a } \\
\text { bank. }\end{array}$ \\
\hline Assessment & Compliant \\
\hline Comments & $\begin{array}{l}\text { The supervisor has no powers to revoke the appointment of an auditor elected by the } \\
\text { shareholders' meeting. FI shall appoint (and discharge) a special auditor whose functions } \\
\text { are partly dictated by FI's guidelines and who must furnish special reports to FI. }\end{array}$ \\
\hline Principle 22. & $\begin{array}{l}\text { Remedial Measures } \\
\text { Banking supervisors must have at their disposal adequate supervisory measures to bring } \\
\text { about timely corrective action when banks fail to meet prudential requirements (such as } \\
\text { minimum capital adequacy ratios), when there are regulatory violations, or where } \\
\text { depositors are threatened in any other way. In extreme circumstances, this should include } \\
\text { the ability to revoke the banking license or recommend its revocation. }\end{array}$ \\
\hline Description & $\begin{array}{l}\text { According to Chapter } 7 \text { ( passage titled "Intervention against banks") of the Banking } \\
\text { Business Act FI has the authority to take remedial action against banks. } \\
\text { Where a Swedish bank has taken a decision which is in contravention of this Act or any } \\
\text { other legislation which regulates the bank's operations, or against a regulation issued by } \\
\text { virtue of such legislation or against the bank's articles of association, FI may enjoin the } \\
\text { execution of the decision. Where the decision has already been executed, the supervisory } \\
\text { authority may order the bank to rescind the decision, where possible. } \\
\text { A Swedish bank's charter shall be revoked in the following circumstances. In the cases } \\
\text { below marked } 4 \text { and 5, a warning may be issued instead of revocation if that is deemed to } \\
\text { be sufficient. } \\
\text { 1. the bank has not submitted an application for registration within the prescribed period } \\
\text { or the application has been withdrawn or cancelled as a result of a decision which has } \\
\text { become final; } \\
\text { the bank has not commenced banking operations within one year after the grant of the } \\
\text { charter or the bank, prior thereto, has declared that it will not be utilizing the charter; } \\
\text { the bank has transferred its entire business; } \\
\text { the bank has not conducted banking operations during a continuous period of six } \\
\text { months; } \\
\text { the bank, as a result of the breach of a provision referred to in Section } 15 \text { or in any }\end{array}$ \\
\hline
\end{tabular}


other manner, has proved itself to be unsuitable to exercise such operations to which the charter relates;

6. the commercial bank's capital base is less than five million euro and the deficiency has not been covered within three months from the discovery of the deficiency by the bank (similar requirements are set forth in the acts regulating savings banks, and member banks;

7. the bank has failed to fulfill its obligations in accordance with the Deposit Guarantees Act and has not undertaken rectification within one year from such time as FI ordered the bank to comply with its obligations with a warning that the bank's charter may be revoked; or

8. any person who is a member of the commercial bank's Board of Directors, or its managing director, or the acting managing director does not possess sufficient insight and experience in order to participate in the management of a bank and is otherwise not suitable for such a task. The commercial bank's charter shall also be revoked where it may be assumed that any such person has failed, to a significant extent, to comply with his obligations in commercial operations or in other financial affairs or has been convicted of serious criminal offences (similar requirements are set forth in the acts regulating savings banks and member banks).

Revocation of charters and the issuance of warnings are decided upon by FI. The government shall determine cases of exceptional importance. FI's Director General has the discretion to refer a case for governmental decision making.

Where a special cause exists, FI may grant an extension to cover the deficiency in the bank's capital base. In the cases where e.g., the managing director has been found unsuitable for his position, the charter may only be revoked where FI has taken a decision to complain about the person and that he or she, following a specified period determined by FI, remains in the position.

Where the charter is revoked, the governmental authority, which decided to revoke the charter, may determine the manner in which the winding up of the business shall take place. An injunction against future operations may be ordered together with a decision in respect of revocation.

Where FI is informed by a competent governmental authority in another country within the EEA of the fact that a Swedish bank has violated the laws of that country, the measures of injunction and warning may be taken against the bank. FI shall inform the competent governmental authority in the other country of the measures undertaken.

When a banking undertaking which is domiciled in a country outside the EEA conducts banking operations from branch offices in Sweden and, in such context, breaches a provision as referred to in Section 15 the Banking Business Act or in any other manner proves itself to be unsuitable to conduct banking operations, the branch office's license shall be revoked or a warning shall be issued if such is deemed to be sufficient. Issues regarding revocation of branch office licenses and the issuance of warnings shall be determined by FI. The government shall determine cases of principle or of exceptional importance.

Where deposits at the branch office are covered by a guarantee as a result of a decision in accordance with the Deposit Guarantees Act, FI may, in the event that the bank fails to fulfill its obligations in accordance with the Deposit Guarantees Act, order the bank to undertake rectification with a warning that the branch office's license will otherwise be revoked. The license may be revoked in the event that rectification has not been undertaken within one year from the date of the order. FI shall inform the supervisory authority in the 
country where the banking undertaking has its registered head office of the measures undertaken.

If a bank domiciled in a country within the EEA conducts operations in Sweden through a branch or by direct provision of services and breaches a legal provision or in any other manner proves itself to be unsuitable to conduct such operations, FI may order the bank to effect rectification. Where the bank fails to comply with the order, FI shall inform the competent governmental authority in the bank's home country. Where rectification is not effected notwithstanding FI's order, FI may enjoin the foreign bank from assuming further obligations in Sweden. Prior to the issuance of the injunction, FI shall inform the home country supervisor. In urgent cases, FI may issue the injunction without prior notification to the home country authority. If the operating license of a bank domiciled in another country within the EEA conducts operations in Sweden has been revoked in its home country, FI shall immediately enjoin the bank from entering into further obligations in Sweden.

According to Section 23 the Banking Business Act, FI may issue orders or injunctions in accordance with the provisions in the Act on pain of a conditional fine.

FI has also the authority to take remedial actions against banks with the support of Chapter 7 of the Capital Adequacy and Large Exposures Act [lag om kapitaltäckning och stora exponeringar för kreditinstitut och värdepappersbolag]. If a bank or a financial group of undertakings:

1. has a capital base which is less than the minimum amount required pursuant to Chapter 2, (8 percent);

2. fails to fulfill the requirements with respect to systems and routines related to registration and classification of credit risks, supervision and verification of market risks and large exposures and interest risks in its operations in their entirety; and calculation of the institution's or the financial group's financial positions; and

3. fails to reduce its large exposures to the permitted levels.

FI shall order the institution or the undertaking in a financial group of undertakings which must prepare the group-based accounting to take appropriate measures in order to rectify the situation.

According to Chapter 7 Section 15, the Capital Adequacy and Large Exposures Act, when FI issues injunctions pursuant to this Act, it may also make such orders subject to conditional fines. The supervisor can not impose penalties for non-compliance, it can only set conditional fines.

The supervisor can not restrict or suspend payments to shareholders or share-repurchases, make decisions barring individuals from banking or replace managers, directors or controlling owners or restrict their powers. No arrangements for a take-over by or a merger with a healthier institution can be imposed on a bank. Nor is it possible to impose conservatorship on an ailing bank. FI cannot either impose restrictions on the current activities of the bank or on asset transfers from the bank.

The supervisor cannot apply penalties and sanctions to the management and/or the Board of Directors of the bank.

There are no laws or regulations that mitigate against the supervisor delaying appropriate corrective actions. However, criminal law concerning civil servants can be said to oblige the supervisor to act promptly when there is a clear need of corrective action. Failure to do so can render responsibility under Chapter 20 Section 1 of the Penal Code for breach of 


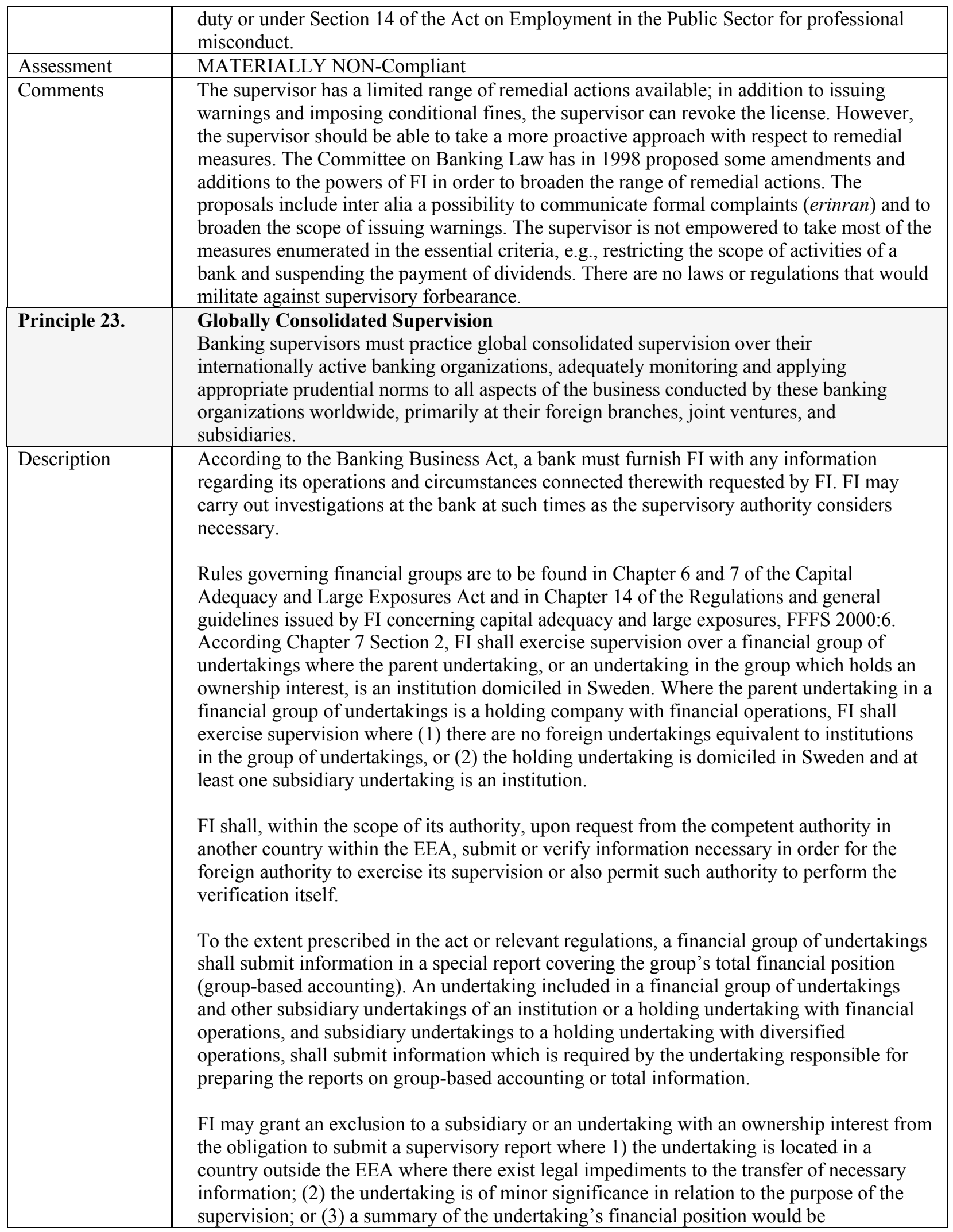




\begin{tabular}{|c|c|}
\hline & 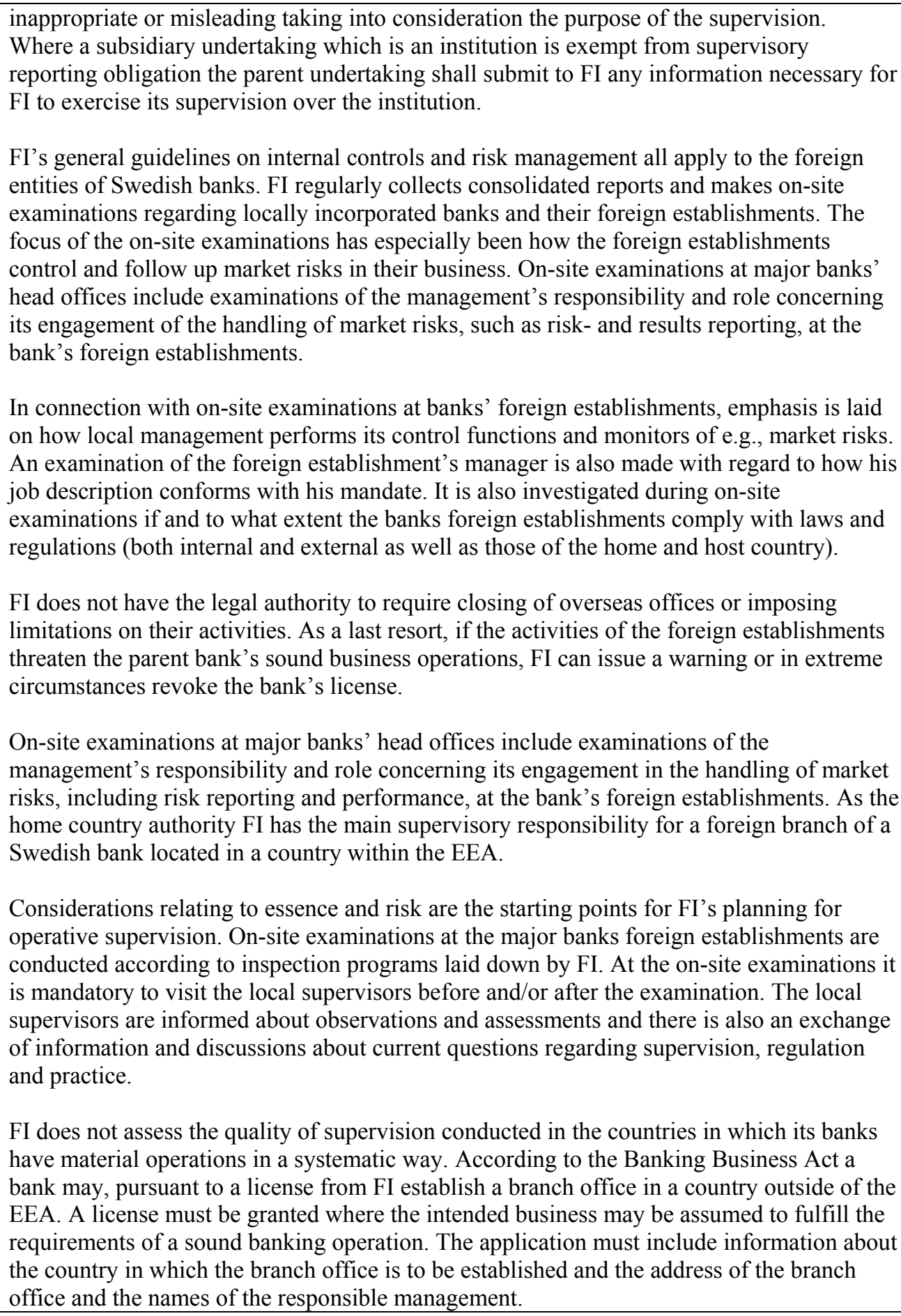 \\
\hline Assessment & Largely Compliant \\
\hline Comments & $\begin{array}{l}\text { FI performs the supervision of banks on a global consolidated basis. The supervisor is not } \\
\text { though empowered to prevent the establishment of branches in jurisdictions where the local } \\
\text { supervisory arrangements are not adequate to the risks involved in the operations. FI has to } \\
\text { take into consideration the preconditions of a sound banking operation. FI also lack powers } \\
\text { to require the closing of overseas offices or limitations on their scope of activities. }\end{array}$ \\
\hline
\end{tabular}




\begin{tabular}{|c|c|}
\hline Principle 24. & $\begin{array}{l}\text { Host Country Supervision } \\
\text { A key component of consolidated supervision is establishing contact and information } \\
\text { exchange with the various other supervisors involved, primarily host country supervisory } \\
\text { authorities. }\end{array}$ \\
\hline Description & 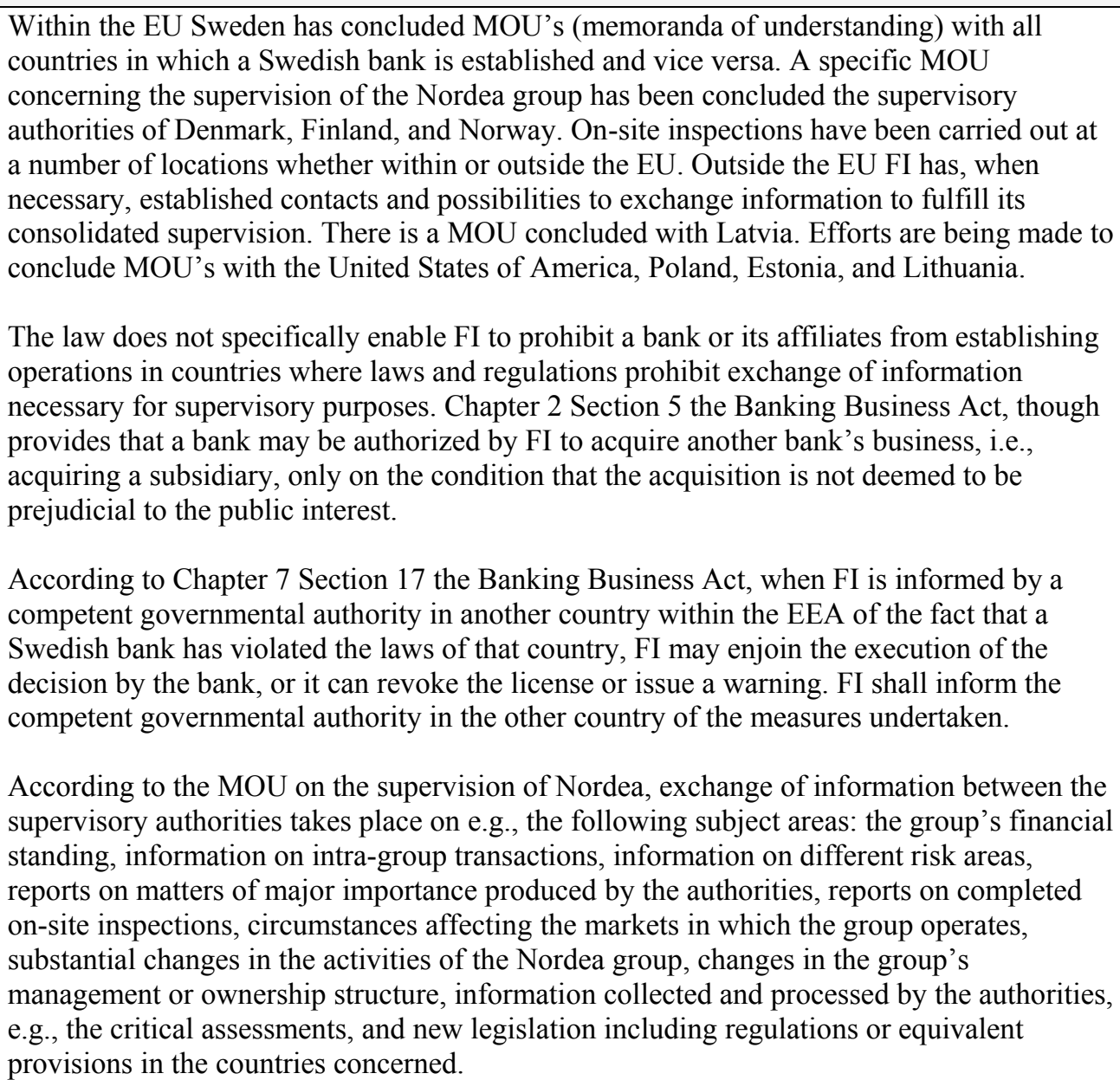 \\
\hline Assessment & Largely Compliant \\
\hline Comments & $\begin{array}{l}\text { FI has entered into MOU's with several foreign supervisory authorities. The authority has } \\
\text { yet to conclude agreements with some of the countries outside the EEA where Swedish } \\
\text { banks have established operations. Referring to the public interest, FI can on the basis of } \\
\text { the Banking Business Act deny authorization for the acquisition of a foreign banking firm } \\
\text { but it cannot deny a license for a branch outside the EEA on the grounds that the free flow } \\
\text { of supervisory information is hindered by local laws or regulations. }\end{array}$ \\
\hline Principle 25. & $\begin{array}{l}\text { Supervision Over Foreign Banks' Establishments } \\
\text { Banking supervisors must require the local operations of foreign banks to be conducted } \\
\text { with the same high standards as are required of domestic institutions and must have } \\
\text { powers to share information needed by the home country supervisors of those banks for } \\
\text { the purpose of carrying out consolidated supervision. }\end{array}$ \\
\hline Description & $\begin{array}{l}\text { Rules governing local operations of foreign banks are in the Banking Business Act. } \\
\text { According to Chapter } 1 \text { Section } 4 \text {, a foreign banking undertaking may conduct banking } \\
\text { business via branch offices having been granted a license to do so; or following notification } \\
\text { to FI, conduct operations which primarily relate to representation and brokering of banking } \\
\text { services from offices or other permanent establishments (representative offices). A license } \\
\text { for the establishment of a branch office in issued by FI. The government shall determine }\end{array}$ \\
\hline
\end{tabular}


cases involving matters of crucial importance or of exceptional significance.

A license for the establishment of a branch office shall be granted where:

1. the planned business may be assumed to fulfill the requirements of a sound banking operation; and

2. deposits with the branch office are covered by the guarantee in accordance with the Deposit Guarantees Act, or by a foreign guarantee which covers deposits as referred to in Section 2 of the Deposit Guarantees Act and which have a maximum compensation level of not less than an amount corresponding to 20,000 Euro prior to any deductions, where applicable, for excess in an amount not exceeding 10 percent of an individual depositor's guaranteed deposit.

A license may not be denied on the basis that no further banks are required.

A license is not required for banking undertakings domiciled in a country within the EEA. Such undertakings may:

1. conduct banking business via branch offices in Sweden commencing two months following receipt of notification by FI from the home country authority; and

2. conduct banking operations by offering and providing services from its home country after FI receives notification from a competent governmental authority

A foreign bank is permitted to engage in the activities enumerated in Chapter 2 Section 2 the Banking Business Act (see CP 2). A foreign banking undertaking may conduct operations referred to in Section 2 only to the extent such operations are covered by the bank's license to conduct operations in the country in which the undertaking maintains its registered office.

With special reference to provisions regarding supervision of branch offices of foreign banking undertakings domiciled within the EEA FI exercises supervision in cooperation with the competent governmental authority in the home country to ensure that the liquidity of the branch office established in Sweden is satisfactory. The branches of foreign banks must submit to FI a profit and loss account four times a year.

Following notification to FI, a competent governmental authority in another country within the EEA may undertake investigations at a branch office established in Sweden of a banking undertaking domiciled in the other country. As to foreign banks domiciled within the EEA which conduct operations in via branch offices or through the direct provision of services, FI shall provide any information to the competent governmental authority in the bank's home country which such authority requires for its supervisory purposes.

FI may issue orders or injunctions in accordance on pain of a conditional fine for both local and foreign establishments. The same standards are applied.

If a bank which is authorized in Sweden at the same time is a subsidiary to a foreign company with which it is consolidated in the home country FI needs to apply the rules on ownership control in an international context as well as needs to make an assessment whether the bank is an integral part of a financial group that is difficult to survey and hence is complicated to supervise. (Chapter 9 Section 3 ). If the home country supervisor practices consolidated supervision it is taken into consideration in the process. The law does not, however, require FI to determine that the home supervisor has given its approval for the establishment of a subsidiary in Sweden.

FI can share information with a supervisory authority in another country according to 


\begin{tabular}{|c|c|}
\hline & 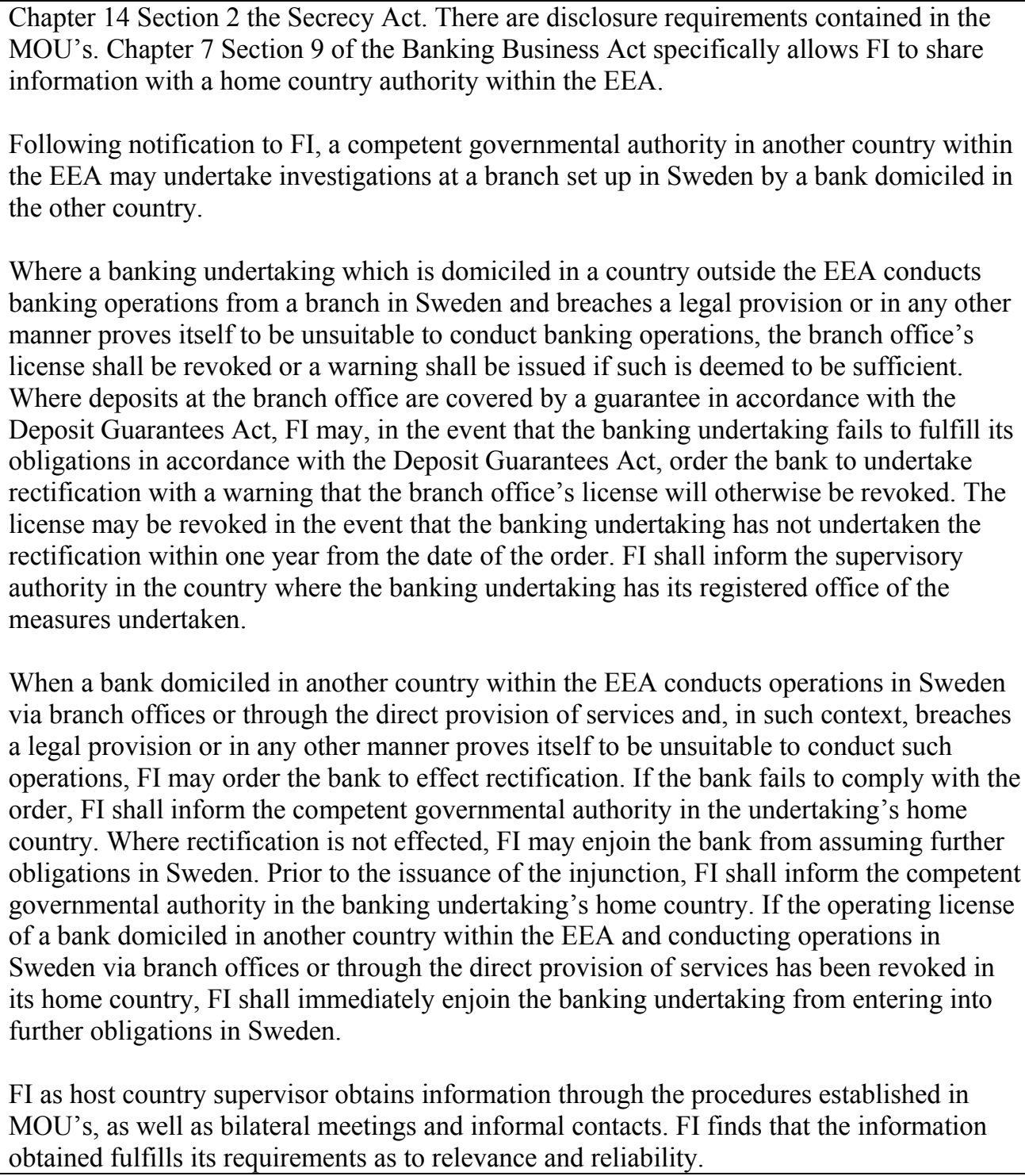 \\
\hline Assessment & Compliant \\
\hline Comments & $\begin{array}{l}\text { The local entities of foreign banks are supervised by FI in cooperation with the respective } \\
\text { foreign authorities. The law does not state that the host supervisor needs to determine that } \\
\text { approval (or no objection) from the home supervisor has been received for a foreign } \\
\text { establishment. In the context of ownership control the FI does consult the foreign authority. }\end{array}$ \\
\hline
\end{tabular}


Table 2. Summary Compliance of the Basel Core Principles

\begin{tabular}{|l|c|c|c|c|c|}
\hline \multicolumn{1}{|c|}{ Core Principle } & $\mathrm{C}^{-1 /}$ & $\mathrm{LC}^{2 /}$ & $\mathrm{MNC}_{3 /}$ & $\mathrm{NC}^{4 /}$ & $\mathrm{NA}^{5 /}$ \\
\hline 1. Objectives, Autonomy, Powers, and Resources & $\mathbf{x}$ & & & & \\
\hline 1.1 Objectives & $\mathbf{x}$ & & & & \\
\hline 1.2 Independence & $\mathbf{x}$ & & & & \\
\hline 1.3 Legal framework & $\mathbf{x}$ & & & & \\
\hline 1.4 Enforcement powers & $\mathbf{x}$ & & & & \\
\hline 1.5 Legal protection & $\mathbf{x}$ & & & & \\
\hline 1.6 Information sharing & $\mathbf{x}$ & & & & \\
\hline 2. Permissible Activities & & $\mathbf{x}$ & & & \\
\hline 3. Licensing Criteria & $\mathbf{x}$ & & & & \\
\hline 4. Ownership & $\mathbf{x}$ & & & & \\
\hline 5. Investment Criteria & $\mathbf{x}$ & & & & \\
\hline 6. Capital Adequacy & $\mathbf{x}$ & & & & \\
\hline 7. Credit Policies & & $\mathbf{x}$ & & & \\
\hline 8. Loan Evaluation and Loan-Loss Provisioning & & $\mathbf{x}$ & & & \\
\hline 9. Large Exposure Limits & & $\mathbf{x}$ & & & \\
\hline 10. Connected Lending & & $\mathbf{x}$ & & & \\
\hline 11. Country Risk & $\mathbf{x}$ & & & & \\
\hline 12. Market Risks & & $\mathbf{x}$ & & & \\
\hline 13. Other Risks & & $\mathbf{x}$ & & & \\
\hline 14. Internal Control and Audit & $\mathbf{x}$ & & & & \\
\hline 15. Money Laundering & $\mathbf{x}$ & & & & \\
\hline 16. On-Site and Off-Site Supervision & $\mathbf{x}$ & & & & \\
\hline 17. Bank Management Contact & $\mathbf{x}$ & & & & \\
\hline 18. Off-Site Supervision & $\mathbf{x}$ & & & & \\
\hline 19. Validation of Supervisory Information & & $\mathbf{x}$ & & & \\
\hline 20. Consolidated Supervision & & & & \\
\hline 21. Accounting Standards & & & & \\
\hline 22. Remedial Measures & & & \\
\hline 23. Globally Consolidated Supervision & & & \\
\hline 24. Host Country Supervision & & & \\
\hline 25. Supervision Over Foreign Banks' & & & \\
\hline Establishments & & & \\
\hline
\end{tabular}

1/ C: Compliant.

2// LC: Largely compliant.

3/ MNC: Materially non-compliant.

${ }^{4 /} \mathrm{NC}$ : Non-compliant.

5/NA: Not applicable. 


\section{E. Recommended action plan and authorities' response to the assessment}

\section{Recommended action plan}

Table 3. Recommended Action Plan to Improve Compliance of the Basel Core Principles

\begin{tabular}{|c|c|}
\hline Reference Principle & Recommended Action \\
\hline Objectives, Autonomy, Powers, and Resources (CP 1) & $\begin{array}{l}\text { To improve its capacity to supervise particularly } \\
\text { the more complex activities of banks, e.g., } \\
\text { related to market risks, the supervisor has to be } \\
\text { able to increase its competitiveness as an } \\
\text { employer. The growing role of the complex } \\
\text { multinational banking groups has posed FI with } \\
\text { new challenges. In the case of Nordea, } \\
\text { especially, FI has to redefine its role as the lead } \\
\text { supervisor. }\end{array}$ \\
\hline Licensing criteria (CP 3) & $\begin{array}{l}\text { The fit and proper tests ought to be applied to all } \\
\text { the members of a bank's management, e.g., also } \\
\text { to senior executives and managers of foreign } \\
\text { offices. The licensing criteria should also be } \\
\text { There are no detailed criteria for assessing the } \\
\text { suitability of management. The economic } \\
\text { situation of the principal shareholders is assessed } \\
\text { only through public financial statements. }\end{array}$ \\
\hline Loan evaluation and loan-loss provisioning (CP 8) & $\begin{array}{l}\text { The supervisor should be given legally based } \\
\text { powers to require a bank to strengthen its } \\
\text { lending practices, level of provisions and } \\
\text { reserves. Depending on the level of problem } \\
\text { assets, the supervisor should have binding } \\
\text { powers to make a bank adopt policies that will } \\
\text { affect the overall financial strength }\end{array}$ \\
\hline Large exposures (CP 9) & $\begin{array}{l}\text { FI needs to require reporting on geographical } \\
\text { concentrations in its lending. }\end{array}$ \\
\hline Connected lending (CP 10) & $\begin{array}{l}\text { Supervision of connected lending ought to be } \\
\text { enhanced by giving FI the authority to set } \\
\text { individual limits to connected lending and } \\
\text { deduct such loans extended on concessionary } \\
\text { grounds from the bank's capital. Being } \\
\text { authorized to do so in law, FI has yet to issue } \\
\text { regulations on the more detailed contents of the } \\
\text { register of connected lending that has to be kept } \\
\text { in a bank. Arrangements should be for regular } \\
\text { reporting to the supervisor on connected lending } \\
\text { on an individual or aggregate basis. }\end{array}$ \\
\hline Country risk (CP 11) & $\begin{array}{l}\text { FI should issue regulations on the management } \\
\text { of country risk. FI currently relies largely on } \\
\text { quarterly reports on bank country risk exposures } \\
\text { prepared by Riksbank. }\end{array}$ \\
\hline
\end{tabular}




\begin{tabular}{|c|c|}
\hline Other risks (CP 13) & $\begin{array}{l}\text { FI should issue supervisory standards on } \\
\text { exchange and operational risk. FI ought to be } \\
\text { given powers to require a bank to hold capital } \\
\text { against risks other than market and credit risk. }\end{array}$ \\
\hline Internal Control and Audit (CP 14) & $\begin{array}{l}\text { FI should be legally empowered to require a } \\
\text { change in the constitution of a board due to } \\
\text { shortcomings in the skills and knowledge of } \\
\text { board members. }\end{array}$ \\
\hline Consolidated Supervision (CP 20) & $\begin{array}{l}\text { FI should be empowered to circumscribe the } \\
\text { range of activities a bank can engage in through } \\
\text { its foreign operations. FI ought to adopt the } \\
\text { policy of actively assessing the supervisory } \\
\text { arrangements in the host country in order to } \\
\text { safeguard efficient home country supervision. } \\
\text { The authority has yet to conclude agreements } \\
\text { with some of the countries outside the EU where } \\
\text { Swedish banks have established operations. In } \\
\text { the supervision of complex multinational } \\
\text { banking groups FI should adopt the active role of } \\
\text { the lead supervisor in the context of coordinating } \\
\text { the planning and performing of joint } \\
\text { examinations by supervisors from different } \\
\text { jurisdictions. In connection with major foreign } \\
\text { acquisitions by banks FI has to adopt the policy } \\
\text { of consistently assessing the safety and } \\
\text { soundness of the bank's overseas operations. }\end{array}$ \\
\hline Remedial Measures (CP 22) & $\begin{array}{l}\text { The supervisor ought to be given a wider array } \\
\text { of legally binding measures to take a more } \\
\text { proactive approach in order to prevent situations } \\
\text { from arising where the only effective measure } \\
\text { would be revocation of license. The appropriate } \\
\text { laws should also be amended to give the } \\
\text { supervisor powers to take those measures } \\
\text { enumerated in the essential criteria of the } \\
\text { principle. The laws should include provisions } \\
\text { that would explicitly prevent the possibility of } \\
\text { supervisory forbearance. }\end{array}$ \\
\hline Globally Consolidated Supervision (CP 23) & $\begin{array}{l}\text { The supervisor ought to be empowered to } \\
\text { prevent the establishment of branches in } \\
\text { jurisdictions where the local supervisory } \\
\text { arrangements are not adequate to the risk } \\
\text { involved in the operations. FI also lacks powers } \\
\text { to require the closing of overseas offices or } \\
\text { limitations on the scope of activities. }\end{array}$ \\
\hline Host Country Supervision (CP 24) & $\begin{array}{l}\text { FI has yet to conclude agreements on } \\
\text { cooperation with supervisors from some of the } \\
\text { countries where Swedish banks have established } \\
\text { operations. FI cannot deny a license for a foreign } \\
\text { branch on the grounds that the free flow of } \\
\text { supervisory information is hindered by local } \\
\text { laws or regulations. }\end{array}$ \\
\hline
\end{tabular}



establishment of a foreign bank's offices, ought to be required to assess whether the home country supervisor practices effective consolidated global supervision. The law does not state that the host supervisor needs to determine that approval (or no objection) from the home supervisor has been received for a foreign establishment.

\section{F. Authorities' Response to the Assessment}

14. The authorities are in broad agreement with the mission's assessment of FI's observance of the Basel Core Principles for Effective Banking Supervision. FI has asked for substantial budgetary enhancements to address the resource shortcomings noted. A proposal to reform the regulation of banks and credit institutions that would give FI the necessary early intervention powers has been put forward for public comment, with the objective of submitting a bill to parliament by Autumn 2002. The authorities point out that as concerns country risk, FI determines through onsite and offsite inspections that banks policies and procedures are appropriate and adequate.

\section{IAIS Insurance CoRe Principles}

\section{A. General}

15. On July 1, 1991, the Supervisory Service was merged with the supervision of banks and other credit organizations into FI. This merger was accompanied by legal changes that from August 1, 1991, permit financial conglomerates: insurance companies may hold shares in credit institutions and vice versa, and both types of companies may be owned by a holding company, thus forming a financial group.

16. Supervision of insurance companies and of friendly societies (provident and mutualbenefit institutions) is the responsibility of FI, which is an independent State agency. Its work is governed only by legislation and by government Ordinances, which must be published. Final decisions on matters of principle may rest, however, with the government. Administrative courts resolve complaints raised against decisions taken by FI.

17. FI has a total staff of about 170 persons, of which about only 30 (or 18 percent) work in the Department of Insurance and Mutual Funds. This department is divided into three units according to the corresponding area of responsibility: Licensing \& Legal Matters, Supervision, and Risk Analysis. The Board of FI settles matters of principles. The Board has the Director General as the chairman and presently the following members: two members of parliament; one representative each from the MoF, the Bank of Sweden, and the National Board for Consumer Policies; three other members with financial and business experience; and two representatives of the employees. 
18. There are no permanent advisory bodies. FI is at liberty to turn to independent experts and does use this option from time to time.

19. The International Association of Insurance Supervisors (IAIS) was formed in 1992. Its core objective is "to ensure improved supervision of the insurance industry on a domestic, as well as on an international, level in order to maintain efficient, fair, safe and stable insurance markets for the benefit and protection of policyholders." As part of this agenda the IAIS develops standards for insurance supervision. These standards emerge from principles that identify the fundamental elements of effective supervision and the areas in which the supervisor should have authority or even have control.

20. Given the major emphasis on stability inherent in the FSAP, this assessment is based on the Insurance Core Principles (CPs) of the IAIS, which focus on prudential supervision, but also address market conduct and cross border issues. The CPs cover 17 key issues. The conclusion is that of 17 assessed principles, Sweden observes 6 principles and broadly observes also 11 principles.

\section{B. Information and Methodology Used for Assessment}

21. This FSAP assessment has been undertaken on the basis of (1) a self assessment by FI; (2) discussions with senior FI staff; (3) a review of the key legislation relevant to FI and explanations given of the constitutional framework for government administration in Sweden (the most relevant documents being available only in Swedish); and (4) review of a range of FI publications, including its Annual Report and annual Financial Stability Report, and of its website. ${ }^{1}$

\footnotetext{
${ }^{1}$ FI publications reviewed include Act of Secrecy (1980:100), Insurance Business Act (1982:713), Annual Accounts Act (1995:1554), Annual Accounts Act for Insurance Companies (1995:1560), Act on Foreign Insurance Companies operating in Sweden (1998:293), Arrangements between Switzerland and the EC, as implemented in Swedish law (FFFS 1996:222), Secrecy Ordinance (SFS 1980:657), Guideline on certain skills of an insurance broker to get licensed by FI (FFFS 1996:19), Guideline on handling complaints (FFFS 1996:25), Guideline on register of assets equal to the technical provisions (FFFS 1996:30), Guideline on stress test (FFFS 1997:5), Guideline on assessment of owners/management (FFFS 1998:14), Guideline on ethical standards (FFFS 1998:22), Guideline on discount-rates (FFFS 1998:25), Guideline on internal information and internal control (FFFS 2000:3), Guideline on valuation on technical provisions (FFFS 2000:4), Guideline on underwriting and reinsurance risk (FFFS 2000:5). Guideline on annual and interim reports of insurance companies (FFFS 2000:22).
} 
22. FI's self-assessment provided the basis for this FSAP assessment. However, the absence of English translation of the most relevant documents impaired the assessment, causing time-consuming explanations of the Swedish texts by the Swedish colleagues of FI.

\section{Institutional and Macroprudential Setting-Overview}

23. The supervision concerns only private insurance. Social insurance is administrated by special agencies. Social insurance covers guaranteed and income-related pensions, health insurance and industrial injuries. There are also special arrangements for unemployment insurance. Nevertheless, private insurance plays an important role, which seems to be increasing as some benefits from social insurance are subject to reduction. Employers' and employees' associations also have agreed upon benefits, the Second Pillar, supplementing the social insurance cover. This includes pension plans, group life and industrial injuries. Other group and individual insurance arrangements are also widespread.

24. Private insurance is mainly carried out by insurance companies, but there are also some friendly societies. These societies still play a certain, though diminishing role in the sphere of pensions, other life insurance and sickness insurance. They are of different types and sizes, from small local funeral expense funds or sickness funds to nation-wide pension institutions. They are legally different from insurance companies in that they may not act on the market and provide insurance on a commercial basis.

25. An insurance broker is defined as an independent intermediary paid either by commission from the insurance company or by fee from the client. An insurance broker or an insurance broker firm has to be registered and supervised by FI. Insurance brokers must meet certain requirements as regards professional indemnity insurance, professional qualifications and fit- and properness. Brokers are allowed to collect premiums and assist clients in settling claims, but not to administrate such assets. They must inform the client about the commission from the insurer, if the client so requires.

26. It is the duty of FI to ascertain that insurance companies remain solvent and conduct their business in accordance with laws and regulations. Supervision implies consideration of legal, financial, technical and economic matters. As already mentioned, the Swedish legislation has, as far as domestic companies are concerned, laid down the principles of solvency, transparency and good insurance standard.

27. Supervision of the business of a licensed insurance company involves examination of the annual returns which must be submitted to FI before August 1 and, in addition, inspections at the place of business. Some companies have a special auditor appointed by FI (ca. 40 at the moment). Each company, except pure reinsurance companies that do not reinsurance life business or long-term non-life business, must keep a record of the assets covering the technical provisions and follow certain investment regulations.

28. The large nation-wide companies are members of a general federation of insurers, the Swedish Insurance Federation (Sveriges Försäkringsförbund), the objective of which is to 
deal with matters of common interest to Swedish insurers. The local companies have, on their side, two different but parallel organizations to look after their special interests. In addition, there is an association of general agents of Swedish branches of foreign insurance companies. Since 1994 insurers with licensed agencies or branches in Sweden may, with the consent of the Board, join the Swedish Insurance Federation as members.

29. Insurance brokers have a separate organization.

30. All companies transacting motor liability insurance-domestic companies as well as Swedish branches of foreign companies-are required to be members of the Motor Liability Insurance Association. The main objectives of this association are to take care of matters connected with the insurers' common responsibility for damage caused by uninsured owners or drivers of vehicles or untraceable drivers that have caused accidents, and to take measures to facilitate insurance arrangements for foreign cars visiting Sweden or Swedish cars going abroad.

31. There are labor market federations for negotiations between insurers on the one hand and employees and employed agents on the other hand.

32. There are several industry organizations for cooperation within the framework of competition legislation or for more general contacts. ${ }^{2}$ In addition, the Swedish Actuarial Society, the Swedish Insurance Society and the Insurance Bureau for Consumers' Enquiries should be mentioned.

33. Relations between the organizations of the insurance market and FI are not regulated by any legislation but are conducted on an informal basis. They include regular information as well as cooperation in committees and ad hoc groups.

34. At the end of 2000, 482 insurance companies were established on the Swedish market. Together, the insurance groups and firms that belong to the Federation covered nearly 100 percent of the Swedish life market and 94 percent of the non-life market.

35. Life insurance companies' premium income rose by 25 percent to SKR 102.7 billion in 2000. The unit-linked insurance companies' premium income was up 43 percent, while traditional life insurance companies increased their premium income by 13 percent. The year 2000 was thereby the first in which unit-linked insurance premiums surpassed premiums for

\footnotetext{
${ }^{2}$ They are active in the following areas: Personal Injury of Liability Insurance; Emergency; Marketing Executive Officers; Legal Expenses; Fire Protection; Accounting; Insurance Law; Insurance Medicine; Insurance Statistics; Actuarial Research; Policy Conditions; Accident and Sickness Insurance; Marine Insurance; Nuclear Insurance Pool; Life Insurance Taxation; Transport Insurance Pool.
} 
traditional life insurance. Life insurance companies on average maintain good solvency ratio, amounting to 11 in 2000 .

36. Non-life insurance companies' premium income in 2000 amounted to SKR 34.9 billion, 5 percent higher than in 1999. On average, they also hold a 17.2 solvency ratio in 2000. Labor market insurance companies had aggregate premium income of SKR 15.8 billion, down 23 percent on 1999.

37. At year-end, insurance companies managed a total of SKR 1,820 billion, 4 percent higher than at the previous year end. Of this amount, SKR 894 billion (49 percent) was invested in shares and participations, and SKR 711 billion (39 percent) in bonds. Of aggregate investment assets, foreign assets made up SKR 623 billion (34 percent).

38. The importance of the insurance sector relative to the banking system has been increased from 1995 to 2000 continuously, illustrated by the ratio of domestic insurance liabilities to domestic bank deposits increasing from 0.8 to 1.2 .

\section{General Preconditions for Effective Insurance Supervision}

39. The legal framework mainly consists of the Insurance Business Act, regulations, and guidelines for the operations of FI is sufficient. In addition there have been improvements in terms of supervisory tools or legal amendments on the way, which are coming into force next year. So far, almost all IAIS Insurance Core Principles (CP) are observed or broadly observed formally by FI.

40. However, the present serious difficulty in getting skilled staff and the resulting insufficient number of skilled employees have forced FI to define priorities. This of course leads to supervisory weaknesses and vulnerabilities in the insurance sector in the areas that have not been prioritized. For instance in the context of the supervision of financial conglomerates, the vulnerability of the insurance part may affect the other financial sectors of the financial conglomerate concerned in the form of contagion risk. Such a contagion in turn can cause a financial instability of the Swedish national economy with cross-border effects.

41. Because of the resource constraints FI doesn't have the time desirable to examine the reports insurers send to the authority, which is one of FI's primary tasks. FI also needs to find time to continue to develop new methods that would allow a risk-based supervision approach. Hence an effective insurance supervision seems to be jeopardized at the moment.

42. The general social system in Sweden provides a large part of the security needed by individual citizens in different situations. The Social Insurance Board or other public institutions do not compete with the private insurance sector. As a part of the recent reform of the pension system, there is, however, a mandatory unit-linked pensions saving in which the insured has the option to choose external investment funds from a list administered by the Premium Pension Authority. 
43. There are some life insurance companies, which confine themselves exclusively to providing pensions and certain other payments for employees under a collective scheme. Employers and employees are partners in these companies. There are also a number of private life insurers and friendly societies working in the same field.

44. In accordance with the above-mentioned disassociation between social and private insurance, preconditions for effective insurance supervision are fulfilled.

\section{E. Principle-by-Principle Assessment}

\section{Table 4. Detailed Assessment of Observance of the IAIS Insurance Core Principles}

\begin{tabular}{|c|c|}
\hline Principle 1. & 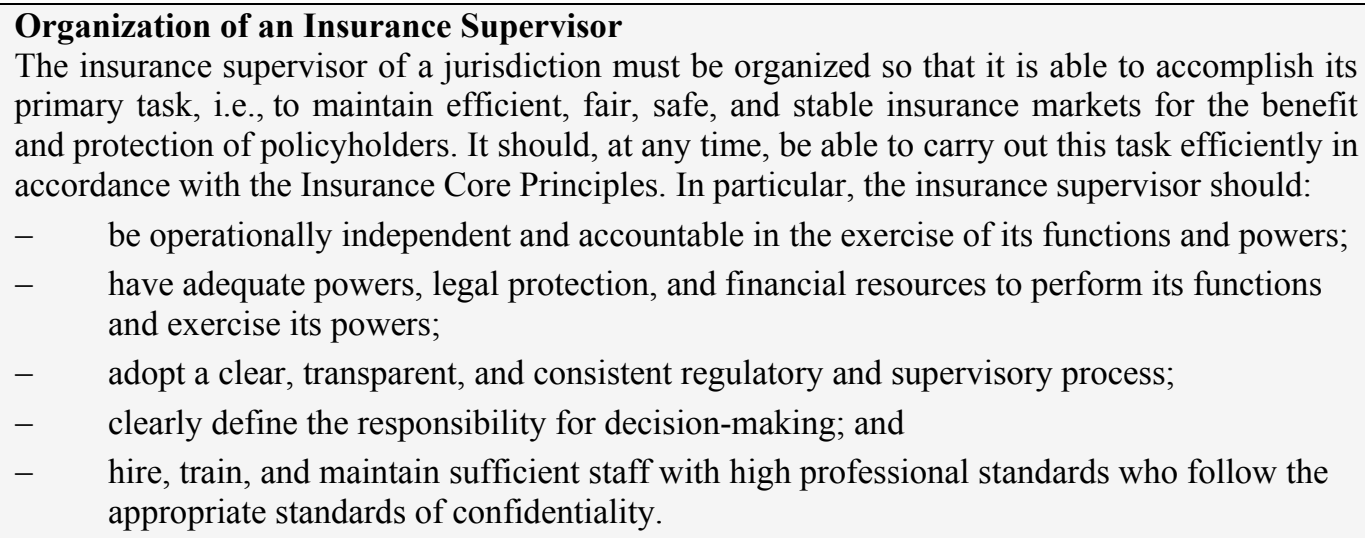 \\
\hline Description & $\begin{array}{l}\text { (a) Independence } \\
\text { FI is an independent authority with its own Board, with representatives from the parliament, the } \\
\text { Central Bank, other authorities and the financial industry. In most cases, the Director General is } \\
\text { the top decision-maker at the authority with the Board as his advisor. The Board decides on } \\
\text { issues such as the annual financial report of FI. } \\
\text { FI makes its own budget requests within the framework of the total state budget, which is put } \\
\text { before the parliament each year. An amount equivalent to the approved budget is charged to } \\
\text { financial institutions subject to supervision. } \\
\text { Given its budget frameworks and the overall objectives, FI is independent in performing its } \\
\text { regulatory and supervisory functions. In order to achieve the overall, general objectives, FI sets } \\
\text { its own operational goals and objectives. } \\
\text { Nevertheless if FI thinks that a legal gap has to be filled FI has to propose a new rule as a } \\
\text { recommendation to the government. The government decides how the legal gap is treated. The } \\
\text { government's decision is binding on FI for all equal and similar cases in the future. } \\
\text { (b) Employment system } \\
\text { The staff represents a mix of highly skilled experts and staff with a broad overall knowledge of } \\
\text { supervision. The operations are based on coordination of risk analysis in specific risk areas and } \\
\text { general supervision. One of the main supervisory objectives is to produce group-wide risk } \\
\text { assessments of major financial groups. } \\
\text { FI is fully in control of its (approved) budget, including salaries, training of staff, equipment, } \\
\text { travels etc. The parliament may not grant } 100 \text { percent of the budget request and hence }\end{array}$ \\
\hline
\end{tabular}




\begin{tabular}{|c|c|}
\hline & $\begin{array}{l}\text { prioritizations have to be made accordingly. } \\
\text { The head of FI is appointed by the government for a minimum term and can be removed from } \\
\text { office during such term only for reasons specified in law. Where the head of an agency is } \\
\text { removed from office, the reasons must be publicly disclosed }\end{array}$ \\
\hline Assessment & Broadly observed. \\
\hline Comments & $\begin{array}{l}\text { Sweden formally observes the organization principle; however, in terms of professional } \\
\text { resources there is scope for further improvement. The ongoing development of methods } \\
\text { regarding risks related to insurance and the new responsibilities for the licensing and } \\
\text { supervision of management companies and mutual funds call for additional resources of } \\
\text { actuaries, risk experts, inspectors and legal counselors. } \\
\text { FI has difficulties in filling existing posts and recruiting qualified staff especially actuaries. } \\
\text { Therefore FI is forced to engage consulting firms for special actuarial and auditing tasks. The } \\
\text { associated costs are paid by FI, but FI's budget is restricted for such activities. Otherwise FI is } \\
\text { legally entitled to appoint actuaries and auditors for special tasks which has been put down in } \\
\text { the law. The appointment of the auditor is restricted for } 5 \text { years. The associated expenditure is } \\
\text { paid by the concerning insurance undertakings. Of course the external actuaries and auditors } \\
\text { have to comply with rules of confidentiality (Act of Secrecy 1980:100). } \\
\text { Actuaries are recruited from the universities mainly; lawyers are recruited from the ministries } \\
\text { primarily. Relating to the recruitment of young academics there is a cooperation between FI and } \\
\text { the University of Stockholm and the insurance industry in particular dealing with insurance } \\
\text { mathematics. The young professionals are educated by special tailored training in-house. } \\
\text { Sometimes it is possible that FI-staff can join seminars of consulting firms or negotiate periods } \\
\text { of practical training in insurance undertakings. The turnover of staff rate amounts to at least } 15 \\
\text { percent. The average period of employment amounts to } 5 \text { to } 10 \text { years. }\end{array}$ \\
\hline Principle 2. & $\begin{array}{l}\text { Licensing } \\
\text { Companies wishing to underwrite insurance in the domestic insurance market should be } \\
\text { licensed. Where the insurance supervisor has authority to grant a license, the insurance } \\
\text { supervisor: } \\
\text { - in granting a license, should assess the suitability of owners, directors, and/or senior } \\
\text { management, and the soundness of the business plan, which could include proforma } \\
\text { financial statements, a capital plan, and projected solvency margins; and } \\
\text { in permitting access to the domestic market, may choose to rely on the work carried out } \\
\text { by an insurance supervisor in another jurisdiction if the prudential rules of the two } \\
\text { jurisdictions are broadly equivalent. }\end{array}$ \\
\hline Description & $\begin{array}{l}\text { (1) } \\
\text { According to Chapter } 2 \text { Section } 3 \text { of the Insurance Business Act (1982:713) a concession } \\
\text { granted by the supervisory authority is a condition for pursuing insurance business. Insurance } \\
\text { business is not defined in the wording of the act but there is a close discussion in the preparatory } \\
\text { work of the act about the concept and the circumstances that should be taken into consideration } \\
\text { such as the need of supervision. There are also guiding decisions made by the court and the } \\
\text { supervisory authority. The guiding decisions refer to insurance brokers mainly, because } \\
\text { insurance brokers are also licensed by FI: } \\
\text { According to the act the supervisory authority has the authority to grant license. There are legal } \\
\text { provisions defining the tasks and responsibilities of the authority. Further particulars are in place } \\
\text { through special instructions issued by the government. } \\
\text { There is a comprehensive legal regulation concerning licensing in the insurance supervision law } \\
\text { and the Insurance Business ordinance issued by the government. This regulation is }\end{array}$ \\
\hline
\end{tabular}


supplemented by regulations and general guidelines issued by the supervisory authority giving more detailed licensing requirements.

\section{$2(2)$}

The permitted types of legal form are defined in the Insurance Business Act.

According to the act, a condition for granting the license is that the natural and legal persons holding a direct or indirect qualifying participation in the applicant company are suitable to have a significant influence on the management of an insurance company. Another condition is that directors, the managing director and the deputy-managing director have sufficient qualifications and are suitable for managing an insurance company.

According to the provisions in the Insurance Business Regulation, an application for license should account for the qualified owners. The details are governed by general guidelines issued by the supervisory authority. The information shall apply to the legal person, the directors, the deputy directors, the managing director, and the deputy-managing director. This information shall also be accounted for concerning the management of the insurance company.

According to the law, the supervisory authority must refuse to issue the license if the owner is not able to establish that the business will be conducted in accordance with the regulations or the owner is unsuitable to have a significant influence on the management of the company. This is for the authority to decide. The owner is always considered to be unsuitable if he has considerably neglected his responsibilities financially or has been involved in serious crime. The information given by the company, according to the authority's general guidelines concerning assessment of owners and management, enables the authority to assess all criteria stated in the third item of the Core Principles Methodology. A shortage may lead the authority to refusing the license.

In most cases the authority obtains information from the tax authority, the enforcement service, the national police board, the register of companies, the register of insider trading, and the register of trade prohibition. This information is handled with the confidentiality requirements stated in the Secrecy Act.

According to the preparatory work it is up to the authority to assess if the owner and management have sufficient qualifications and are sufficiently discerning in order to pursue insurance business on a long term basis according to applicable rules. According to the general guidelines the company has to provide information in order to enable the authority to make that assessment. If the owner is a legal person the information shall refer to the legal person, the directors, the deputy directors, the managing director and the deputy-managing director.

Regarding the legal person, the company shall provide the last annual report and information concerning, group relationship, eventual bankruptcy, tax evasion and the like, the natural persons and his next of kin engagement in the insurance company. This information is checked with other relevant authorities.

Regarding the directors, the deputy directors, the managing director and the deputy managing director, the company has to provide a complete curriculum vitae and a declaration confirming that they have not been involved in any sanctions, criminal proceedings, bankruptcy, tax evasion and the like. The company shall also provide information concerning these people's involvement in other companies in order to assess if there are any conflict of interest.

The supervisory authority has worked out a practice concerning how to deal with different issues actualized during the assessment. 
According to the law, the company is obliged to provide a business plan. The information in the business plan is regulated in the regulation concerning business plan issued by the authority. All information stated in items 7 and 8 of the Core Principles Methodology is to be provided.

The minimum amount of capital required for all companies is regulated in the law. If the capital is below the minimum amount, the authority has to take remedial actions (e.g., requirement of a restoration plan due to the third EEC directives).

According to the law, the company has to have a satisfactory equity ratio. In order to ensure this the supervisory authority normally requires a capital base doubling the required solvency margin.

The prerequisites and criteria for outsourcing are stated in a standpoint issued by the authority. A standpoint is not directly legally binding for the insurance companies but the authority always checks outsourcing contracts before granting a license. The company always corrects shortages related to the standpoint. According to the standpoint the company should also inform the authority of all outsourcing contracts entered into when pursuing business. This is not always observed.

According to the EEC directives, the insurance supervisory is not allowed to request and check informational material, policy conditions or the like as a prerequisite for granting a license. However it is possible for the authority to do so after granting a license as a part of the supervising procedures. This is regularly done regarding the technical conditions which, according to the law, shall be provided to the authority when they are put into practice at the latest.

The documents required for licensing include information on formation of the company and name and address of the company, management, auditors, authorized signatory, and evidence of payment of share capital or initial fund. The law does not explicitly require the company to provide information concerning the actuaries but the company is obliged to have access to an authorized actuary. In order to ensure this, the authority always require this information before registering the company.

According to the law it is not possible, as a general rule, to operate life insurance and non-life insurance in the same company except for accident and health insurance (e.g., permanent health insurance (PHI)) as a supplement to life insurance. It is also possible to operate both kinds of business if this was the case at the time of conclusion of the EEC agreement May 2, 1992. If both kinds of business are operated in the same company they are to be operated separately and the capital base for each business is to be calculated and reported also separately.

According to the law the supervisory authority is able to revoke the license if the company no longer complies with the requirements for a license or in another way seriously neglects its responsibilities.

FI usually decides on licensing. If the licensing involves matters of principal nature or particular importance, the decision is referred to the government. Even in those cases the application is handled by the authority and the authority recommends a decision to the government. The government's decision, always comprehensively motivated, is send to the authority.

The authority has issued a memorandum with information concerning the regulation and requirements for licensing. The memorandum is available on the authority's web site. 


\begin{tabular}{|c|c|}
\hline & $\begin{array}{l}\text { Regarding EEA insurers the supervisory authority is obliged to allow an establishment or cross- } \\
\text { border activities if the supervisory authority of the home country certifies that the company } \\
\text { fulfills the requirements in the home country and also provides some information concerning the } \\
\text { company stated in the law. } \\
\text { Regarding insurers outside the EEA they have to have a license issued by the Swedish authority. } \\
\text { The procedure is the same as for domestic companies. }\end{array}$ \\
\hline Assessment & Broadly observed. \\
\hline Comments & $\begin{array}{l}\text { Sweden does not observe the licensing principle. Because of a lack in the relevant Act FI is not } \\
\text { able to carry out the fit and proper test for an insurance company's senior management/key } \\
\text { persons (e.g., heads of the investment and legal departments, controller etc.). That presents an } \\
\text { increment of the management risk. } \\
\text { Existing composite insurance companies will be allowed to continue their operations as at } \\
\text { present, but are obliged to keep separate accounting and records for life and non-life activity. } \\
\text { There is a hierarchy within the different sources of the Swedish legal system. An act is the } \\
\text { strongest legal requirement. Then comes the regulation. Act and regulation are both compulsory. } \\
\text { The third one is the guideline, which has the character of a recommendation. If an insurance } \\
\text { company does not comply with a guideline it has to give sound reasons for its non-compliance. } \\
\text { Insurance companies should inform FI of all outsourcing contracts entered into when pursuing } \\
\text { business. In order to enhance the enforcement of this standpoint the according requirement } \\
\text { should be formulated as a regulation. } \\
\text { The Appointed Auditor is required to review the outsourcing contracts case by case depending } \\
\text { on decision of FI, but there is no legal basis for this requirement. Therefore this requirement } \\
\text { should be incorporated into the guideline for Appointed Auditors. From a long-term perspective } \\
\text { the requirement should be integrated into the Insurance Business Act and from a short-term } \\
\text { perspective it is recommended to establish a new guideline concerning general lines of } \\
\text { outsourcing contracts. } \\
\text { Regarding insurers outside the EEA they should receive a license issued by FI only if the } \\
\text { corresponding home insurance supervisory authority complies with the IAIS Insurance Core } \\
\text { Principles. Thus a license could serve as an incentive for complying with these principles. }\end{array}$ \\
\hline Principle 3. & $\begin{array}{l}\text { Changes in Control } \\
\text { The insurance supervisor should review changes in the control of companies that are licensed in } \\
\text { the jurisdiction. The insurance supervisor should establish clear requirements to be met when a } \\
\text { change in control occurs. These may be the same as, or similar to, the requirements which apply } \\
\text { in granting a license. In particular, the insurance supervisor should: } \\
\text { - } \quad \text { require the purchaser or the licensed insurance company to provide notification of the } \\
\text { change in control and/or seek approval of the proposed change; and } \\
\text { establish criteria to assess the appropriateness of the change, which could include the } \\
\text { assessment of the suitability of the new owners as well as any new directors and senior } \\
\text { managers, and the soundness of any new business plan. }\end{array}$ \\
\hline Description & $\begin{array}{l}\text { Regarding changes in the ownership, according to the law (Chapter } 2 \text { Section } 3 \text { and Chapter } 3 \\
\text { Sections 2, 2a-2d Insurance Business Act (1982:713)), FI's permission is a prerequisite for } \\
\text { acquisition of shares leading to a qualified holding. Anyone who is going to sell a qualified } \\
\text { holding is obliged to inform FI. } \\
\text { FI evaluates the proposed change in the ownership, as described in } 2 \text { (2) of Principle } 2 \text { above, } \\
\text { but similar to the assessment on the framework of changes of control, there is no fit and proper } \\
\text { test including sufficiency of qualification, experience and suitability of the persons concerned. }\end{array}$ \\
\hline
\end{tabular}




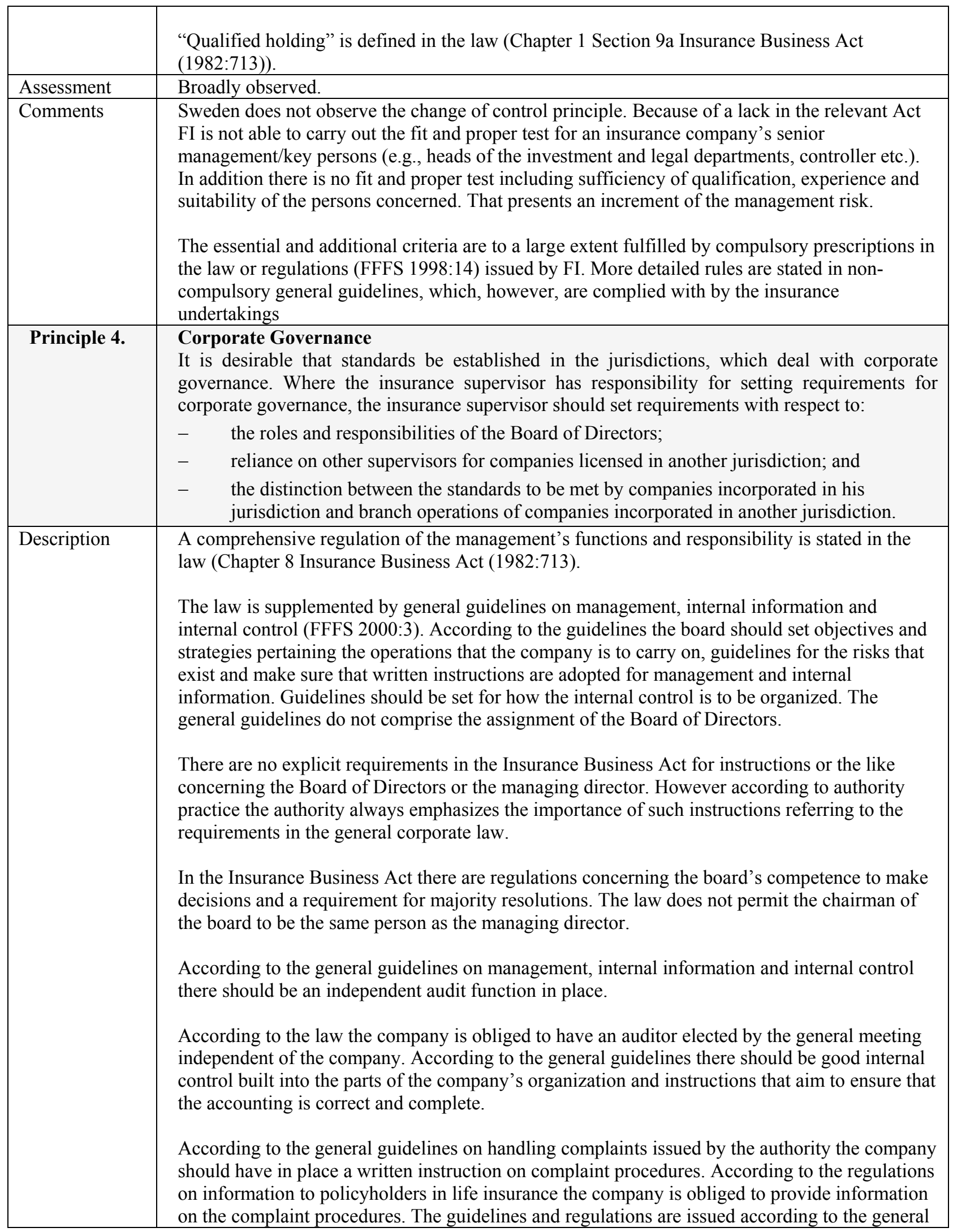




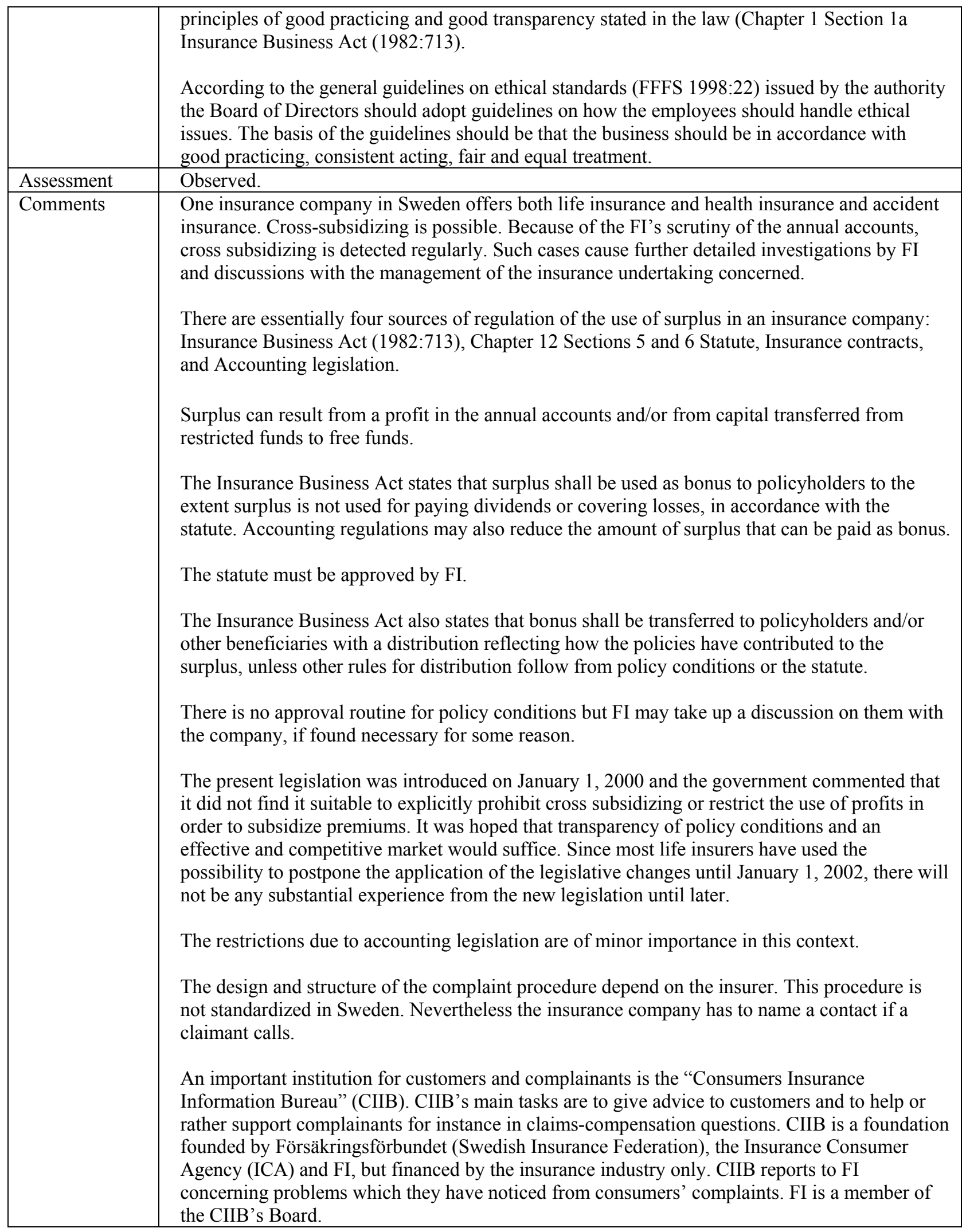




\begin{tabular}{|c|c|}
\hline & $\begin{array}{l}\text { The primarily dimensions of the general principles of good practicing and good transparency are } \\
\text { equitability, financial stability, fairness and security. In addition FI established guidelines on } \\
\text { ethical standards. } \\
\text { For example the ethical standards inter alia refer to the Employment Act. The ethical standards } \\
\text { require the companies to carry out follow-ups in whose framework any breaches of the } \\
\text { employment act have to be controlled. FI reviewed the implementation of the guidelines on } \\
\text { ethical standards in more than } 10 \text { of the biggest Swedish insurance companies. All these } \\
\text { companies implemented those standards but in some cases they had to be amended. Ethical } \\
\text { standards are supporting the financial stability, because the compliance with them may have } \\
\text { influence on the mitigation of reputation risk and operational risks (e.g., fraud, investment area). }\end{array}$ \\
\hline Principle 5. & $\begin{array}{l}\text { Internal Controls } \\
\text { The insurance supervisor should be able to: } \\
\text { - } \quad \text { review the internal controls that the Board of Directors and management approve and } \\
\text { apply, and request strengthening of the controls where necessary; and } \\
\text { - } \quad \text { require the Board of Directors to provide suitable prudential oversight, such as setting } \\
\text { standards for underwriting risks and setting qualitative and quantitative standards for } \\
\text { investment and liquidity management. }\end{array}$ \\
\hline Description & $\begin{array}{l}\text { FI looks upon the internal control mainly in two different ways; on-site inspections and review } \\
\text { demanded accounts. Before an on-site-inspection FI demands the company to send guidelines } \\
\text { and policies for review. FI also looks through protocols from meetings by the Board of } \\
\text { Directors. That makes it possible to review the organizational structure and makes sure that the } \\
\text { insurer for example has a clear delegation of authority. From the protocols FI can see if the } \\
\text { Board gets correct and sufficient information before decisions are made. After that FI has a } \\
\text { meeting with the Managing Director and the Chairman of the Board, where FI gets a brief } \\
\text { presentation of the insurer and its organization. FI also meets the internal auditor, directors } \\
\text { responsible for different areas and usually the investment staff. The on-site inspection produces } \\
\text { a report where FI can make remarks or demand changes. If FI discovers serious inaccuracies or } \\
\text { insufficient control the authority can give the insurer a critical comment depending on the } \\
\text { importance of the failure concerned or an injunction to correct the failure. On-site inspections } \\
\text { are done with support of rules and regulations. FI has issued detailed guidelines about internal } \\
\text { control in general (FFFS 2000:3) and more specifics about underwriting and reinsurance risk } \\
\text { (FFFS 2000:5)and valuation of technical provisions (FFFS 2000:4). FI also reviews insurers } \\
\text { books (accounts). FI designates an auditor (appointed auditor) who reports to the authority and } \\
\text { takes part in the audit of the insurer. FI also demands regular reports in specific areas. }\end{array}$ \\
\hline Assessment & Observed. \\
\hline Comments & $\begin{array}{l}\text { In bigger companies the internal control is satisfying, of course there are always things to } \\
\text { improve and FI often makes minor remarks. Generally FI makes more remarks to smaller } \\
\text { companies, usually about the internal audit. However, concerning the current practice there is a } \\
\text { tendency to make also more remarks to bigger undertakings. } \\
\text { In accordance with guideline FFFS } 2000: 3 \text { every insurer has to set up a reporting system } \\
\text { referring to internal control/risk management. The risk management report is submitted to the } \\
\text { Board of Directors. FI has the opportunity to review this report via its appointed auditor or the } \\
\text { report has to be presented to the authority on demand. The report's submission to FI is not } \\
\text { mandatory. Because of the enhancing importance of the risk-based supervision for insurance } \\
\text { undertakings, it should be implemented into the Insurance Business Act that the annual risk } \\
\text { management report has to be presented to FI for scrutiny. }\end{array}$ \\
\hline
\end{tabular}




\begin{tabular}{|c|c|}
\hline Principle 6. & $\begin{array}{l}\text { Assets } \\
\text { Standards should be established with respect to the assets of companies licensed to operate in } \\
\text { the jurisdiction. Where insurance supervisors have the authority to establish the standards, these } \\
\text { should apply at least to an amount of assets equal to the total of the technical provisions, and } \\
\text { should address: } \\
\text { - diversification by type; } \\
\text { - } \quad \text { any limits, or restrictions, on the amount that may be held in financial instruments, } \\
\text { property, and receivables; } \\
\text { - } \quad \text { the basis for valuing assets which are included in the financial reports; } \\
-\quad \text { the safekeeping of assets; } \\
\text { - } \quad \text { appropriate matching of assets and liabilities; and } \\
\text { - liquidity. }\end{array}$ \\
\hline Description & $\begin{array}{l}\text { In the law there are compulsory rules concerning the capital investment regarding the amount of } \\
\text { assets equal to the technical provisions. The regulations address diversification by type of assets, } \\
\text { the limits of the amount that may be held in the different types of assets and in an individual } \\
\text { investment, the basis for valuing assets, appropriate matching off assets and liability, and liquidity. } \\
\text { Safekeeping of assets and accountability for asset transactions is regulated in the regulations and } \\
\text { general guidelines on register of assets equal to the technical provisions (FFFS 1996:30). } \\
\text { According to the law the company shall set and observe a strategic investment policy concerning } \\
\text { assets equal to the technical provisions. The Board of Directors shall adopt the policy. There are no } \\
\text { regulations concerning the contents of the policy. } \\
\text { In the general guidelines on management, internal information and internal control, there is a } \\
\text { general requirement addressing the board on setting guidelines on handling of the risks that arise in } \\
\text { the company's operations. The types of risk defined in the guidelines are among those mentioned } \\
\text { in the questionnaire. The scope of the guidelines should be that managing, identification and } \\
\text { monitoring of the risks is satisfactory to ensure that the company can meet its commitments under } \\
\text { insurance contracts in force. There should also be instructions that would ensure good internal } \\
\text { control (see Principle 5). In addition, the delegation of responsibility should be defined. } \\
\text { FI reviews the company's guidelines. The review is carried out on an ad hoc basis by off-site } \\
\text { inspection at the moment. This is a case-by-case procedure. If the authority considers the } \\
\text { guidelines not in compliance with the law or insufficient this opinion is emphasized to the } \\
\text { company to ensure the responsibility and control of the Board of Directors. However as long as the } \\
\text { guidelines are not in conflict with the law the authority is not able to take any remedial actions. }\end{array}$ \\
\hline Assessment & Observed. \\
\hline Comments & $\begin{array}{l}\text { The complete existing regulation gives FI sufficient remedy to act when necessary. } \\
\text { FI applies a very simple stress test at the moment (FSSS 1997:5). FI intends to introduce a more } \\
\text { sophisticated dynamic resilience test in 2002, although this kind of test is not explicitly required by } \\
\text { the IAIS Insurance Core Principles. } \\
\text { In life insurance the liabilities are most prudently assessed. The assets are assessed on the basis of } \\
\text { market values. In non-life insurance on the liabilities side it is not allowed to discount the technical } \\
\text { provisions. Their assessment is very close to the expected value. The annual premium is used as an } \\
\text { estimator for the technical provisions. Assets are also assessed on the basis of market values. } \\
\text { The policyholder's surplus is not part of the technical provisions. In the case of unit linked policies } \\
\text { the investment risk is transferred to the policyholders. The guaranteed interest rate amounts to } 3.0 \\
\text { percent per annum at the moment. }\end{array}$ \\
\hline
\end{tabular}


Concerning the segregation of the assets of policyholders and shareholders, FI established a general guideline on register of assets (FFFS 1996:30) equal to the technical provisions. An insurer's unearned premium reserve is monitored by the company's auditor and FI's employees concerned.

Relating to Chapter 7 Section 10g Insurance Business Act (1982:713) the insurance companies are required to set up an annual report on their strategic investment policy. This report is submitted to FI on demand only. On the other hand parts of those reports' contents are disclosed to the public in the framework of economic journalism.

Because of the shortfall of qualified staff, FI does not always have the possibility to react when, for example the reports from an insurer indicate a breach of investment regulation (increment of investment risks; see recommendation to Principle 1).

\section{Principle 7. $\quad$ Liabilities}

Insurance supervisors should establish standards with respect to the liabilities of companies licensed to operate in their jurisdiction. In developing the standards, the insurance supervisor should consider:

- $\quad$ what is to be included as a liability of the company, for example, claims incurred but not paid, claims incurred but not reported, amounts owed to others, amounts owed that are in dispute, premiums received in advance, as well as the provision for policy liabilities or technical provisions that may be set by an actuary;

- $\quad$ the standards for establishing policy liabilities or technical provisions; and

- $\quad$ the amount of credit allowed reducing liabilities for amounts recoverable under reinsurance arrangements with a given reinsurer, making provision for the ultimate collectability.

The liability of a company is described in Chapter 7, Section 1 Insurance Business Act (1982:713):

A company's technical provisions shall correspond to the amount that is required for the company to meet all liabilities that reasonably can be expected from policies issued.

The technical provisions shall correspond to the company's liability for:

Claims, administration and other costs covering the remaining period of the contracts for policies in force.

Claims incurred but not paid, costs for settling those claims and bonus due to payment (more non-life).

Such bonus that is guaranteed as face value (= nominal value) or real value (reference to a commitment in relation to the consumer price index) and that is not covered by 1 . or 2 (only in running contracts, which having guaranteed a bonus for enhancement of the sum insured (sequence of bonuses which are guaranteed for the corresponding rest of the insurance period); very seldom and not traditional in Sweden, therefore small amount).

Such bonus that is dependent on changes in values of assets or technical results where the policyholder carries the financial risk.

Equalization of losses in credit insurance (setting up of equalization reserves in the insurance class of credit insurance).

Unit-linked insurance where the policyholder carries the financial risk. 


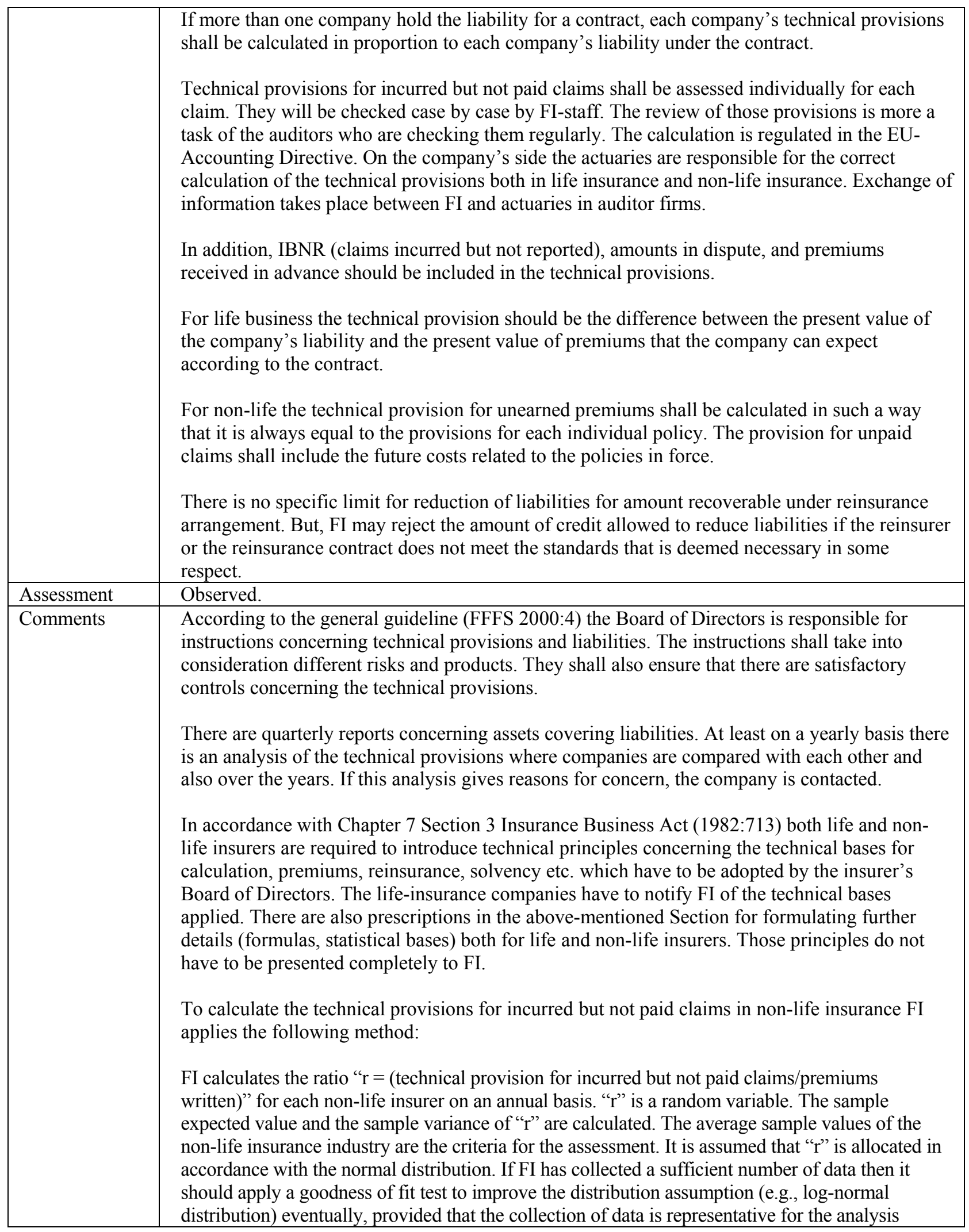




\begin{tabular}{|c|c|}
\hline & concerned. \\
\hline Principle 8. & $\begin{array}{l}\text { Capital Adequacy and Solvency } \\
\text { The requirements regarding the capital to be maintained by companies which are licensed, or } \\
\text { seeking a license, in the jurisdiction should be clearly defined and should address the minimum } \\
\text { levels of capital or the levels of deposits that should be maintained. Capital adequacy } \\
\text { requirements should reflect the size, complexity, and business risks of the company in the } \\
\text { jurisdiction. }\end{array}$ \\
\hline Description & $\begin{array}{l}\text { Regarding capital adequacy and solvency Sweden is following EU jurisdiction as far as } \\
\text { possible. Local jurisdiction reflects for all main purposes EU rules and complementary } \\
\text { regulations are few. In connection with a company seeking a license in the jurisdiction FI } \\
\text { requires three years business plans. In order to give a license FI should consider the business } \\
\text { plan as realistic and the solvency in the end of the three years period should fulfill the } \\
\text { requirements according to the jurisdiction. The jurisdiction does not regulate the size of capital } \\
\text { required-the evaluation is performed by FI and can vary from case to case depending on the } \\
\text { concrete circumstances. } \\
\text { Each company-life and non-life reports yearly in the end of May the solvency status. The } \\
\text { reporting is registered and reviewed electronically. Insurers with material declines in solvency } \\
\text { margin since the prior reporting period or reporting a solvency margin below the required } \\
\text { minimum levels are followed up manually. FI contacts insurance companies that are considered } \\
\text { to have problems to discuss measures for improving the solvency margin. }\end{array}$ \\
\hline Assessment & Broadly observed. \\
\hline Comments & $\begin{array}{l}\text { FI complies with the corresponding EU-directives. } \\
\text { As of today the solvency requirement is measured and evaluated on a yearly basis. Though this } \\
\text { topic is currently under discussion and in the near future FI will have a requirement that at given } \\
\text { time intervals, insurance companies assess the amount of their available solvency margins } \\
\text { (capital) (Solvency I). FI's experience is that difference in assets markets values is the single } \\
\text { major reason for changes in solvency margin during a year. } \\
\text { FI requires the insurance companies in difficulties to present a plan for quick restoring of capital } \\
\text { in compliance with the solvency rules. } \\
\text { Concerning an insurance company's seeking license according to jurisdiction, it is common that } \\
\text { FI has the permission to intervene and require the insurance company to hold capital at a higher } \\
\text { level than the required minimum margin where circumstances exist to justify such an action. For } \\
\text { older companies FI's practice is not so clear, but in principle FI has the described option. } \\
\text { A disclosure note in the register is needed in order to inform FI whether parts of the assets are } \\
\text { not free (collaterals), or can not be applied to covering the technical reserves. } \\
\text { In spring } 2002 \text { FI intends to introduce qualitative risk assessment for insurance risks. Extending } \\
\text { the application of risk-based supervisory tools as envisaged next year is a welcome } \\
\text { development. } \\
\text { Up to now FI could not comment on the requirement that the inflation of supervisory capital } \\
\text { through double/multiple gearing or other financing techniques in an "insurance group" should be } \\
\text { eliminated and the structure of the "insurance group" should be transparent (essential criterion } 10 \\
\text { of CP 8). This is because the formulating of the corresponding regulation has still not been } \\
\text { finalized. Effecting the appropriate regulation as envisaged on January } 1,2002 \text { is a welcome } \\
\text { development. }\end{array}$ \\
\hline
\end{tabular}




\begin{tabular}{|c|c|}
\hline Principle 9. & $\begin{array}{l}\text { Derivatives and 'Off-Balance Sheet' Items } \\
\text { The insurance supervisor should be able to set requirements with respect to the use of financial } \\
\text { instruments that may not form a part of the financial report of a company licensed in the } \\
\text { jurisdiction. In setting these requirements, the insurance supervisor should address: } \\
\text { - } \quad \text { restrictions in the use of derivatives and other off-balance sheet items; } \\
-\quad \text { disclosure requirements for derivatives and other off-balance sheet items; and } \\
\text { - } \quad \text { the establishment of adequate internal controls and monitoring of derivative positions. }\end{array}$ \\
\hline Description & $\begin{array}{l}\text { According to the law (Chapter } 7 \text { Section 17b Insurance Business Act, 1982:713) the use of } \\
\text { derivatives is restricted only to reduce the financial risk and to rationalize the management of } \\
\text { the assets. The supervisory authority has been given the right to issue regulations concerning the } \\
\text { application of the law. This right has not been used, because there are no such rules on Swedish } \\
\text { banks either. } \\
\text { Moreover, see principle } 6 \text { above. } \\
\text { Even if there are no regulations concerning the application of the law the authority constantly } \\
\text { reviews the capital investments and has the possibility to take remedial actions regarding the } \\
\text { responsibility of the Board of Directors to ensure that the business is pursued to maintain a } \\
\text { sufficient equity, liquidity and control over, among other things, investment risks. } \\
\text { Disclosure requirements should be established for derivatives and other off-balance sheet items. } \\
\text { FI's control of adequate internal controls and monitoring of derivative positions is done within } \\
\text { on- site inspections concerning internal controls and via the appointed auditors (see } \\
\text { recommendation to Principle 5). }\end{array}$ \\
\hline Assessment & Broadly observed. \\
\hline Comments & $\begin{array}{l}\text { FI issues regulations and general guidelines concerning the annual and interim reports of } \\
\text { insurance companies (FFFS 2000:22). These regulations include disclosure requirements for } \\
\text { derivatives and off-balance sheet items. The disclosure requirements for derivatives and off- } \\
\text { balance sheet items include quantitative as well as qualitative disclosure requirements. The } \\
\text { disclosure requirements are to a high extent based on IAS } 32 \text { (Financial Instruments: disclosure } \\
\text { and presentation).The application of mark to market values as shown in IAS } 32 \text { is better than the } \\
\text { application of historical values } \\
\text { Disclosure requirements should be established for derivatives and off-balance sheet items. } \\
\text { FI's requirements are fulfilled: FI requires insurers using derivatives to have in place an } \\
\text { appropriate policy for their use, formulated and approved by the Board of Directors. } \\
\text { Furthermore, FI requires that this policy should be consistent with the company's activities, its } \\
\text { overall strategic investment policy and asset/liability management strategy, and its risk } \\
\text { tolerance. The policy concerned complies with the main elements described in the essential } \\
\text { criteria 9.3. It addresses the following main elements: the purposes for which derivatives can be } \\
\text { used; the establishment of appropriately structured exposure limits for derivatives taking into } \\
\text { account the purpose of their use and the uncertainty caused by market credit, liquidity, cash } \\
\text { flow, operation and legal risk; the extent to which the holding of some types of derivatives is } \\
\text { restricted or not authorized; and the delineation of lines of responsibility and a framework of } \\
\text { accountability for derivatives functions. }\end{array}$ \\
\hline
\end{tabular}




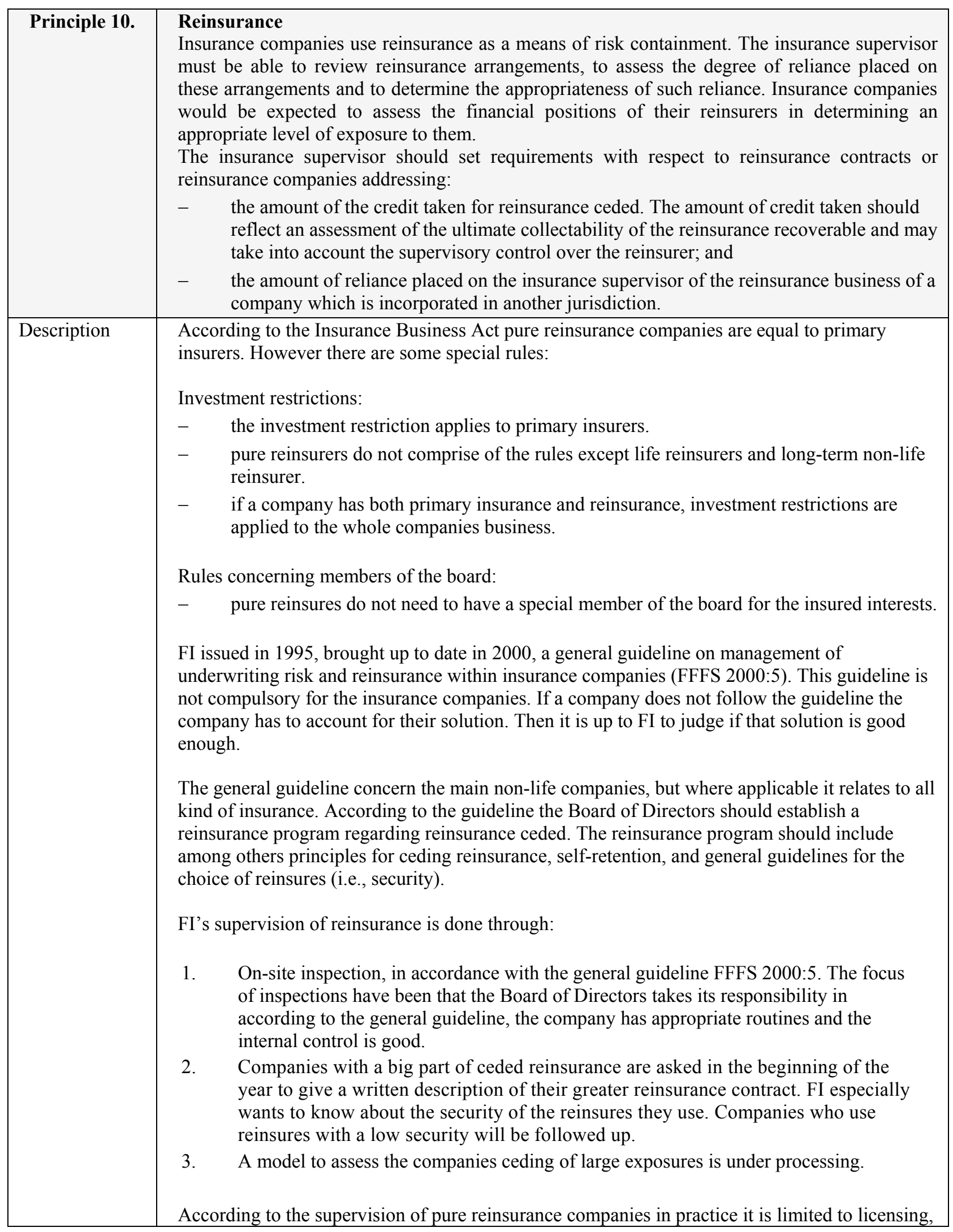




\begin{tabular}{|c|c|}
\hline & $\begin{array}{l}\text { reporting of the annual report and the solvency report. In Sweden today there are only a few } \\
\text { Swedish reinsurance companies in business. Most of the big insurance groups have set their } \\
\text { reinsurance companies in run-off. }\end{array}$ \\
\hline Assessment & Broadly observed. \\
\hline Comments & $\begin{array}{l}\text { Pure reinsurance companies are supervised in almost the same way as primary insurance } \\
\text { undertakings. FI has set up a general guideline (FFFS 2000:5). According to the general } \\
\text { guideline the Board of Directors should take a reinsurance policy concerning ceded reinsurance. } \\
\text { Because of the shortfall of qualified staff FI is not able to scrutinize the reinsurance contracts } \\
\text { regularly (increment of reinsurance risk; see recommendation to Principle 1). } \\
\text { Primary insurers ceded reinsurance will be supervised through on site inspections, although the } \\
\text { frequency has not yet been stipulated. Used reinsures security will be supervised through the } \\
\text { yearly questionnaire. } \\
\text { A model that assesses the companies ceding large exposures is on the way. This helps FI and } \\
\text { insurers to identify major risks and to take measures to cover these risks. Introducing this } \\
\text { supervisory instrument, as envisaged in } 2002 \text { is a welcome development. }\end{array}$ \\
\hline Principle 11. & 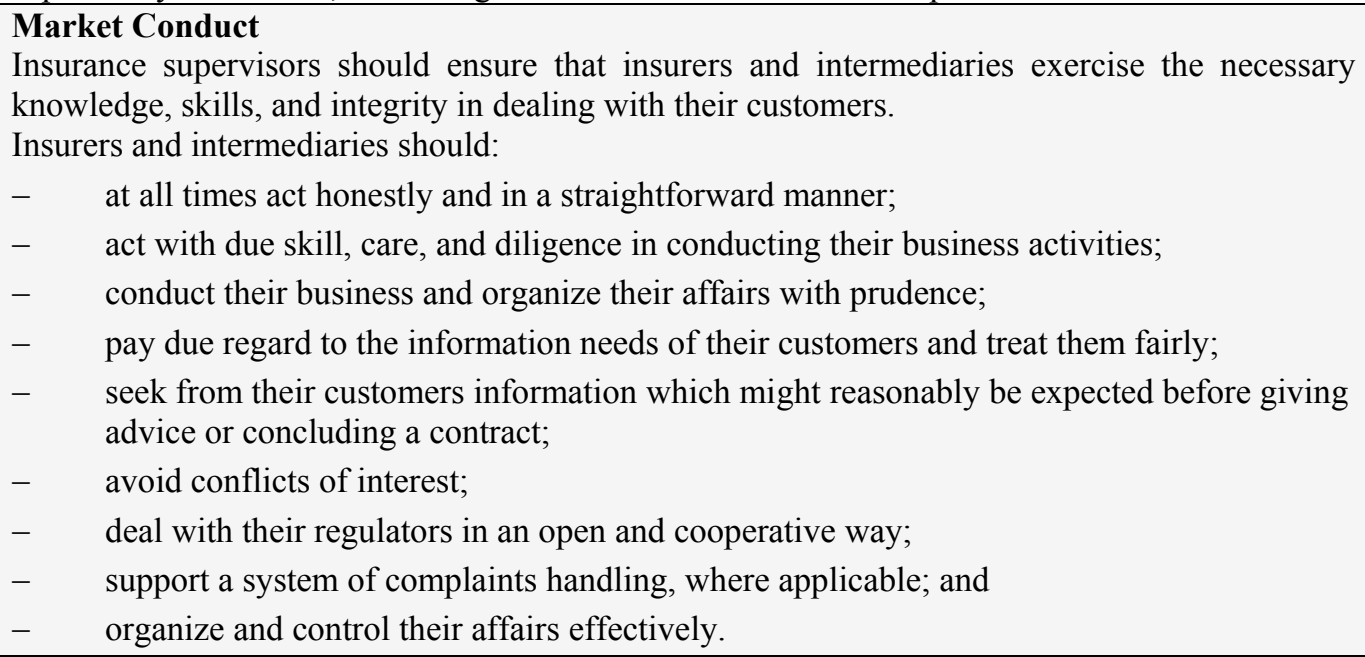 \\
\hline Description & $\begin{array}{l}\text { Acquisition of insurance is FI's responsibility but marketing is not. An insurance broker has to } \\
\text { have certain skills to get licensed by FI (FFFS 1996:19). FI has issued rules about experience } \\
\text { and theoretical knowledge for brokers. A person who gets a license must be fit and proper. The } \\
\text { insurance companies have full responsibility for all other persons selling insurance. In } \\
\text { conducting an on-site inspection on internal control, FI usually gets information about a } \\
\text { company's selling-organization and its policy in that area. Life and non-life insurance are } \\
\text { usually separated in this exercise. In life insurance FI now focuses on information given to the } \\
\text { insured as well as presumptive customers. It is very important that the customer understands the } \\
\text { information given by the companies and that the information is relevant to the customer. At } \\
\text { present FI makes on-site inspections to see how insurers prepare themselves for the newly } \\
\text { issued information-rules. When selling a non-life insurance it is very important that the broker } \\
\text { or the seller figures out the customers needs. FI does not accept that a person should be twice } \\
\text { insured for the same risk. Therefore the broker or seller needs relevant information from the } \\
\text { customer. It is not so common that FI makes on-site inspections in this area. But FI usually } \\
\text { makes on-site inspections to see how insurers deal with claims and specialty personal injuries. } \\
\text { FI thinks it is important that the injured gets compensation on objective grounds even without } \\
\text { the assistance of a lawyer, and that the company deals with its claim in due order with secrecy. } \\
\text { FI reviews how companies deal with customer complaints. Every company has to appoint a } \\
\text { person who is responsible for customer complaints. FI has listed all appointed persons in a }\end{array}$ \\
\hline
\end{tabular}




\begin{tabular}{|c|c|}
\hline & $\begin{array}{l}\text { register and can assist claimants with information. In conducting an on-site inspection on } \\
\text { internal control, FI always demands to see the guidelines for handling complaints (FFFS } \\
\text { 1996:25). FI does not handle complaints but can use the information. FI starts an off-site } \\
\text { inspection to investigate how a company deals with complaints, if it gets a lot of similar } \\
\text { complaints. }\end{array}$ \\
\hline Assessment & Broadly observed. \\
\hline Comments & $\begin{array}{l}\text { Due to insufficient resources in the insurance division of FI the authority does not usually make } \\
\text { on-site inspections at insurance-brokers, ad hoc-inspections not included. FI receives a lot of } \\
\text { information that brokers do not fulfill the requirements but FI does not have the possibility to } \\
\text { respond on such information. In general in Sweden it is difficult to have any supervision } \\
\text { concerning market conduct, which presents an increment of underwriting risk (see } \\
\text { recommendation to Principle 1). } \\
\text { Normally FI has no problems with market conduct. FI acts against complaints, reads about } \\
\text { grievances in newspapers or otherwise receives information about grievances. FI has during } \\
\text { recent years made companies' inspections on claims and personal injuries. In general it takes too } \\
\text { long for companies to handle personal injuries. This is caused by a certain shortage of adjusters } \\
\text { and therefore it is difficult to overcome this problem. } \\
\text { It is recommended to establish procedures to ensure that companies are in compliance with } \\
\text { legislation and guidelines. }\end{array}$ \\
\hline \multirow[t]{8}{*}{ Principle 12.} & $\begin{array}{l}\text { Financial Reporting } \\
\text { It is important that insurance supervisors get the information they need to properly form an } \\
\text { opinion on the financial strength of the operations of each insurance company in their } \\
\text { jurisdiction. The information needed to carry out this review and analysis is obtained from the } \\
\text { financial and statistical reports that are filed on a regular basis, supported by information } \\
\text { obtained through special information requests, on-site inspections, and communication with } \\
\text { actuaries and external auditors. }\end{array}$ \\
\hline & $\begin{array}{l}\text { A process should be established for: } \\
\text { - } \quad \text { setting the scope and frequency of reports requested and received from all companies } \\
\text { licensed in the jurisdiction, including financial reports, statistical reports, actuarial } \\
\text { reports, and other information; }\end{array}$ \\
\hline & $\begin{array}{l}\text { - } \quad \text { setting the accounting requirements for the preparation of financial reports in the } \\
\text { jurisdiction; }\end{array}$ \\
\hline & $\begin{array}{l}\text { - } \quad \text { ensuring that external audits of insurance companies operating in the jurisdiction are } \\
\text { acceptable; and }\end{array}$ \\
\hline & $\begin{array}{l}\text { - } \quad \text { setting the standards for the establishment of technical provisions or policy and other } \\
\text { liabilities to be included in the financial reports in the jurisdiction. }\end{array}$ \\
\hline & In so doing, a distinction may be made: \\
\hline & $\begin{array}{l}\text { between the standards that apply to reports and calculations prepared for disclosure to } \\
\text { policyholders and investors, and those prepared for the insurance supervisor; and }\end{array}$ \\
\hline & $\begin{array}{l}\text { - between the financial reports and calculations prepared for companies incorporated in the } \\
\text { jurisdiction, and branch operations of companies incorporated in another jurisdiction. }\end{array}$ \\
\hline \multirow[t]{2}{*}{ Description } & $\begin{array}{l}\text { According to Insurance Business Act, Insurance Business Decree and other laws (Insurance } \\
\text { Brokers Act, Friendly Societies Act) FI has the permission to set the scope and frequency of } \\
\text { reports requested, including financial reports, statistical reports and actuarial reports, and } \\
\text { received from all companies licensed in the jurisdiction. }\end{array}$ \\
\hline & $\begin{array}{l}\text { There are quite a few regulations issued by FI that regulate the collection of } \\
\text { statistical data. There are for instance regulations concerning: profit and loss accounts; } \\
\text { performance analysis; solvency; analysis of profitability; cross-border activities; and assets }\end{array}$ \\
\hline
\end{tabular}




\begin{tabular}{|c|c|}
\hline & $\begin{array}{l}\text { (quarterly reports). } \\
\text { The external auditors in Sweden have a good reputation as competent and independent. } \\
\text { FI has the permission to appoint an auditor. An appointed auditor works for FI, but is paid for } \\
\text { by the company. He has the same rights and responsibilities as the auditors appointed by the } \\
\text { general meeting. FI has appointed auditors in nation-wide larger insurance companies and in } \\
\text { companies with known problems. } \\
\text { FI has the permission to stipulate the principles and norms regarding } \\
\text { accounting and consolidation techniques (groups and conglomerates (IAS } 22,27 \text { (consolidated } \\
\text { financial statements) to be used for the purposes of reports provided to it for supervisory } \\
\text { purposes. All listed companies in Sweden agree upon the recommendation of the Swedish } \\
\text { Accounting Standard Counsel. } \\
\text { FI requires insurance companies to utilize valuation rules that are consistent, realistic and prudent. } \\
\text { FI has the permission to issue principles for the establishment of technical provisions (policy } \\
\text { liabilities) and other liabilities to be included in the financial reports in the jurisdiction (FFFS } \\
2000: 22 \text { pages } 18,20 \text { ). }\end{array}$ \\
\hline Assessment & Broadly observed. \\
\hline Comments & $\begin{array}{l}\text { FI has the permission to request the information the authority needs. This is also done regarding } \\
\text { to the actual laws. A review of the requested reporting has started. The aim of the review is to } \\
\text { find out if it is possible to reduce the amount of information reported to FI. } \\
\text { Insurance companies in Sweden have to comply with the accounting regulations in the Annual } \\
\text { Accounts Act for Insurance Companies, "Lagen om årsredovisning i försäkringsföretag, } \\
\text { (1995:1560), ARFL" The act is partly an implementation of the Insurance Accounting } \\
\text { Directive, 91/674/EEG, IAD. } \\
\text { ARFL refers to a great extent (mainly related to accounting issues not specific for financial } \\
\text { institutions) to paragraphs in the Annual Accounts Act, "Ârsredovisningslagen, (1995:1554), } \\
\text { ARL." ARL applies to general companies, and is the result of the Swedish implementation of } \\
\text { the fourth and seventh EU Company directives on annual accounts and consolidated accounts. } \\
\text { According to Chapter } 1 \text { Section } 4 \text { of ÅFL, FI has the right to issue binding regulations in the } \\
\text { accounting area. FI has issued such regulations and general guidelines that consist of. } \\
\text { Regulations that implement certain parts of the IAD; } \\
\text { Clarifications of ARFL, and more detailed accounting regulation on accounting for financial } \\
\text { instruments and insurance contracts. } \\
\text { So the accounting laws provide the legal framework and the more detailed regulation is } \\
\text { provided by the binding regulations issued by FI. } \\
\text { In the annual financial statements, insurance companies must state whether they comply with } \\
\text { the regulations issued by FI. Any deviation must be disclosed and could render a qualified } \\
\text { opinion by the auditor. } \\
\text { The Annual Accounts Act for Insurance Companies states that all Swedish insurance companies } \\
\text { must issue annual reports. } \\
\text { The regulations issued by FI state that insurance companies with net assets exceeding } \\
\text { SKR } 1 \text { million must publish one interim report yearly. }\end{array}$ \\
\hline
\end{tabular}


In FI's opinion the auditors in general are acceptable and have a high standard in knowledge and independence.

Under certain circumstances insurance companies are required to utilize valuation rules that are consistent, realistic and prudent.

Under certain circumstances and special provisions in the Insurance Business Act

(Försäkringsrörelselagen) (Chapter 7 Sections 1, 2), FI has the permission to issue principles for the establishment of technical provisions (policy liabilities) and other liabilities to be included in the financial reports in the jurisdiction (FFFS 1998:25 (discount-rate)).

The actuarial report needs to be amended:

(a) Life insurance: the Responsible Actuary should take into account the asset-side when forming an opinion of the financial status of the company. A corresponding prescription should be incorporated into the Insurance Business Act.

(b) Non-life insurance: non-life actuaries are reporting more about the reserves' development. Hence for reasons of the quality-guarantee of the actuarial report the non-life Responsible Actuary should sign his report. This procedure should be written into a FI-regulation.

\begin{tabular}{|c|c|}
\hline \multirow[t]{3}{*}{ Principle 13.} & $\begin{array}{l}\text { On-Site Inspection } \\
\text { The insurance supervisor should be able to: }\end{array}$ \\
\hline & $\begin{array}{l}\text { carry out on-site inspections to review the business and affairs of the company, including } \\
\text { the inspection of books, records, accounts, and other documents. This may be limited to } \\
\text { the operation of the company in the jurisdiction or, subject to the agreement of the } \\
\text { respective supervisors, include other jurisdictions in which the company operates; and }\end{array}$ \\
\hline & $\begin{array}{l}\text { - } \quad \text { request and receive any information from companies licensed in its jurisdiction, whether } \\
\text { this information be specific to a company or be requested of all companies. }\end{array}$ \\
\hline Description & $\begin{array}{l}\text { FI's activities are guided by legislation. The Insurance Business Act also stipulates that the } \\
\text { Board of Directors, managing directors and other officers responsible for the business are } \\
\text { obliged to provide requested information to FI. FI can review company-branches, and has a } \\
\text { bilateral MOU with Kredittilsynet in Norway about inspections and information concerning an } \\
\text { insurance company. FI works with different manuals and FI usually demand written information } \\
\text { before visiting a company. For larger insurers, an on site inspection lasts 2-3 days and is carried } \\
\text { out at least once a year. The on site inspection procedure starts with sending a special } \\
\text { questionnaire designed by FI to the concerning insurer. After a certain period the insurance } \\
\text { company submits its answers FI. FI analyzes the company's reply. Usually the result of the } \\
\text { analysis leads to further questions, which are discussed with the company's senior people during } \\
\text { FI's company visit. Afterwards FI sends an official letter including the on site inspection report } \\
\text { to the inspected insurer for comments. The report is revised. The final report is sent to the } \\
\text { insurance undertaking for information only. }\end{array}$ \\
\hline Assessment & Observed. \\
\hline Comments & $\begin{array}{l}\text { FI has not had problems in getting the information it needs or in conducting inspections. } \\
\text { Normally FI gives companies time to prepare a visit. For the IAIS assessment, FI has demanded } \\
\text { information the same day or arranged a meeting in a few days. }\end{array}$ \\
\hline Principle 14. & $\begin{array}{l}\text { Sanctions } \\
\text { Insurance supervisors must have the power to take remedial action where problems involving } \\
\text { licensed companies are identified. The insurance supervisor must have a range of actions } \\
\text { available in order to apply appropriate sanctions to problems encountered. The legislation } \\
\text { should set out the powers available to the insurance supervisor and may include: } \\
\text { - the nower to restrict the business activities of a comnany for example by withholding }\end{array}$ \\
\hline
\end{tabular}




\begin{tabular}{|c|c|}
\hline & $\begin{array}{l}\text { approval for new activities or acquisitions; } \\
\text { the power to direct a company to stop practices that are unsafe or unsound, or to take } \\
\text { action to remedy an unsafe or unsound business practice; and } \\
\text { the option to invoke other sanctions on a company or its business operation in the } \\
\text { jurisdiction, for example, by revoking the license of a company or imposing remedial } \\
\text { measures where a company violates the insurance laws of the jurisdiction. }\end{array}$ \\
\hline Description & 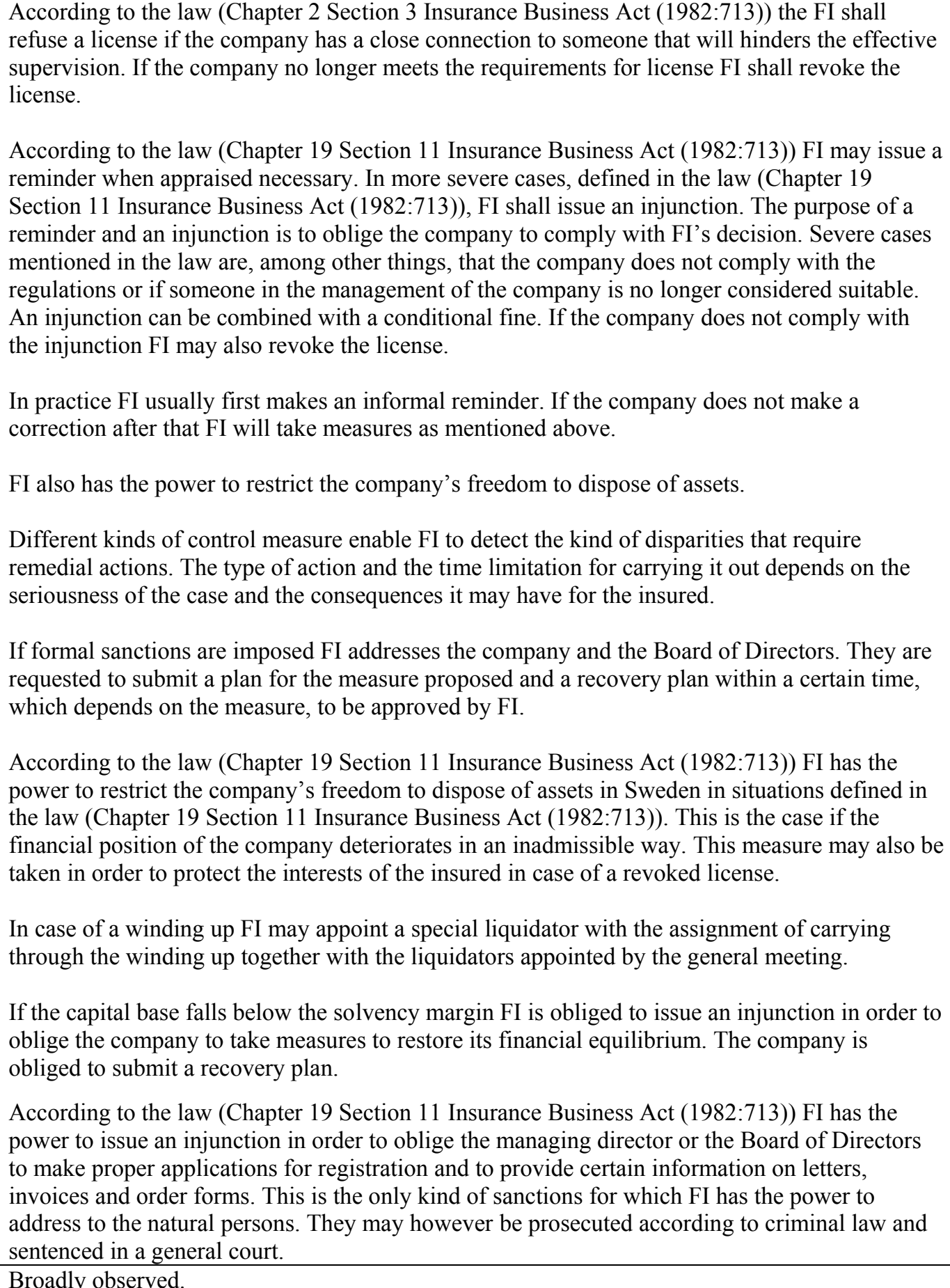 \\
\hline
\end{tabular}




\begin{tabular}{|c|c|}
\hline Comments & $\begin{array}{l}\text { FI has the power to take remedial actions when necessary. On the whole FI is given the } \\
\text { possibility of choosing an adequate sanction. However FI is lacking in the possibility of issuing } \\
\text { a formal criticism in cases where there is a need for a sharp reprimand but not obliging the } \\
\text { company to take measures. }\end{array}$ \\
\hline Principle 15. & $\begin{array}{l}\text { Cross-Border Business Operations } \\
\text { Insurance companies are becoming increasingly international in scope, establishing branches } \\
\text { and subsidiaries outside their home jurisdiction, and sometimes conducting cross-border } \\
\text { business on a services basis only. The insurance supervisor should ensure that: } \\
\text { - } \quad \text { no foreign insurance establishment escapes supervision; } \\
\text { - } \quad \text { all insurance establishments of international insurance groups and international insurers } \\
\text { are subject to effective supervision; } \\
\text { - } \quad \text { the creation of a cross-border insurance establishment is subject to consultation between } \\
\text { host and home supervisors; and } \\
\text { foreign insurers providing insurance cover on a cross-border services basis are subject to } \\
\text { effective supervision. }\end{array}$ \\
\hline Description & $\begin{array}{l}\text { The provisions concerning cross-border business operations are written in Chapter 2a Insurance } \\
\text { Business Act (1982:713) and in Chapter } 2 \text { Act on Foreign Insurance Companies operating in } \\
\text { Sweden (1998:293). } \\
\text { FI acts in accordance with the Directives on life assurance and non-life insurance. It also acts in } \\
\text { accordance with the protocol relating to the collaboration of the supervisory authorities of the } \\
\text { Member States of the European Community in particular in the application of the Directives on } \\
\text { life assurance and non-life insurance. } \\
\text { For EEA insurers, home country control and the principle of one single license are valid, } \\
\text { according to the third generation EC insurance directives as implemented into Swedish } \\
\text { legislation. The activities of a Swiss insurer in Sweden are regulated in accordance with the } \\
\text { special arrangements between Switzerland and the EC, as implemented in Swedish law (FFFS } \\
\text { 1996:222). } \\
\text { Cross-border activities are possible for EEA insurers after a prescribed notification procedure to } \\
\text { the home country authority of the head-office. For an EEA insurer, the home country authorities } \\
\text { are responsible for supervision and the capital requirements of the home country apply. For a } \\
\text { non-EEA insurer, the same rules apply as for domestic companies. } \\
\text { Chapter } 4 \text { Act on Foreign Insurance Companies operating in Sweden contains provisions } \\
\text { concerning non-EEA insurers. For non-EEA insurers, cross-border activities without } \\
\text { authorization are only possible through intermediation by an independent insurance broker or } \\
\text { when insurance is sought actively by the policyholder. Otherwise they can operate only through } \\
\text { an insurer authorized in Sweden with whom they have an agreement of cooperation or if they } \\
\text { both belong to the same group of companies. Authorization from FI is then needed. } \\
\text { The creations of cross-border insurance establishment are subject to consultation between host } \\
\text { and home supervisors. The supervisory authorities involved are obliged to conduct a mutual } \\
\text { consultation before approving a transfer of portfolio, according to the Chapter } 9 \text { Section } 7 \text { Act } \\
\text { on Foreign Insurance Companies operating in Sweden. }\end{array}$ \\
\hline Assessment & Broadly observed. \\
\hline Comments & $\begin{array}{l}\text { It is not clear whether Sweden is in a position to actively supervise branches of Swedish-based } \\
\text { insurers in other EEA member States in practice, given the very limited resources of the } \\
\text { supervisor (see recommendation to Principle 1). } \\
\text { There is only one foreign insurance undertaking which is operating business in Sweden. This }\end{array}$ \\
\hline
\end{tabular}




\begin{tabular}{|c|c|}
\hline & $\begin{array}{l}\text { financial institution is a general agency of the Swiss insurer ZFS (Zürich Financial Services) } \\
\text { running non-life insurance business in Sweden only. The general agent has been licensed by FI. } \\
\text { FI supervises all legal matters of this general agency (e.g., claims compensation, fit and proper } \\
\text { aspects etc.) while the Swiss insurance supervisory authority does all financial matters (e.g., } \\
\text { solvency, accounting etc.) }\end{array}$ \\
\hline \multirow[t]{5}{*}{ Principle 16.} & $\begin{array}{l}\text { Coordination and Cooperation } \\
\text { Increasingly, insurance supervisors liaise with each other to ensure that each is aware of the } \\
\text { other's concerns with respect to an insurance company that operates in more than one } \\
\text { jurisdiction, either directly or through a separate corporate entity. } \\
\text { In order to share relevant information with other insurance supervisors, adequate and effective } \\
\text { communication should be developed and maintained. } \\
\text { In developing or implementing a regulatory framework, consideration should be given to } \\
\text { whether the insurance supervisor: }\end{array}$ \\
\hline & $\begin{array}{l}\text { - } \quad \text { is able to enter into an agreement or understanding with any other supervisor both in } \\
\text { other jurisdictions and in other sectors of the industry (i.e., insurance, banking, or } \\
\text { securities) to share information or otherwise work together; }\end{array}$ \\
\hline & $\begin{array}{l}\text { is permitted to share information, or otherwise work together, with an insurance } \\
\text { supervisor in another jurisdiction. This may be limited to insurance supervisors who have } \\
\text { agreed, and are legally able, to treat the information as confidential; }\end{array}$ \\
\hline & $\begin{array}{l}\text { - should be informed of findings of investigations where power to investigate fraud, money } \\
\text { laundering, and other such activities rests with a body other than the insurance } \\
\text { supervisor; and }\end{array}$ \\
\hline & $\begin{array}{l}\text { - is permitted to set out the types of information and the basis on which information } \\
\text { obtained by the insurance supervisor may be shared. }\end{array}$ \\
\hline \multirow[t]{3}{*}{ Description } & $\begin{array}{l}\text { FI in Sweden does the supervision of the financial sector. Within FI everyone has access to } \\
\text { information. Exchange of information between authorities is subject to secrecy legislation. FI } \\
\text { has the authority to come to an agreement with a foreign financial supervisory authority. It has } \\
\text { been done with Kredittilsynet (Norwegian financial supervisory authority) about a non-life } \\
\text { company, if it is a Swedish non-life company and has about } 40 \text { percent of the Norwegian } \\
\text { insurance business of the private area. In the agreement it is stipulated that the two authorities } \\
\text { will exchange information. }\end{array}$ \\
\hline & $\begin{array}{l}\text { A company supervised by FI has an obligation to inform FI if they have been exposed to an } \\
\text { attempt to fraud, money laundering, etc. }\end{array}$ \\
\hline & Regarding the remaining part of the principle, refer to principle 17 below. \\
\hline Assessment & Observed. \\
\hline \multirow[t]{2}{*}{ Comments } & $\begin{array}{l}\text { All information within FI is public. If someone asks for certain information from FI concerning } \\
\text { a company FI has to do a secrecy trial before FI can set out information. Information concerning } \\
\text { business secrets is always classified. If FI has signed an agreement of cooperation concerning } \\
\text { the supervision of a special company, and the duty of confidentiality is agreed it is possible to } \\
\text { share classified information. }\end{array}$ \\
\hline & $\begin{array}{l}\text { FI supervises seven financial conglomerates. In connection with this supervision FI carries out } \\
\text { an overall assessment for } 13 \text { entities: } 6 \text { insurance companies, } 4 \text { banking groups, and } 3 \text { security } \\
\text { firms. }\end{array}$ \\
\hline \multirow[t]{2}{*}{ Principle 17.} & $\begin{array}{l}\text { Confidentiality } \\
\text { All insurance supervisors should be subject to professional secrecy constraints in respect of } \\
\text { information obtained in the course of their activities, including during the conduct of on-site } \\
\text { inspections. }\end{array}$ \\
\hline & The insurance supervisor is required to hold confidential any information received from other \\
\hline
\end{tabular}




\begin{tabular}{|c|c|}
\hline & $\begin{array}{l}\text { insurance supervisors, except where constrained by law or in situations where the insurance } \\
\text { supervisor who provided the information provides authorization for its release. } \\
\text { Jurisdictions whose confidentiality requirements continue to constrain or prevent the sharing of } \\
\text { information for supervisory purposes with insurance supervisors in other jurisdictions, and } \\
\text { jurisdictions where information received from another insurance supervisor cannot be kept } \\
\text { confidential, are urged to review their requirements. }\end{array}$ \\
\hline Description & 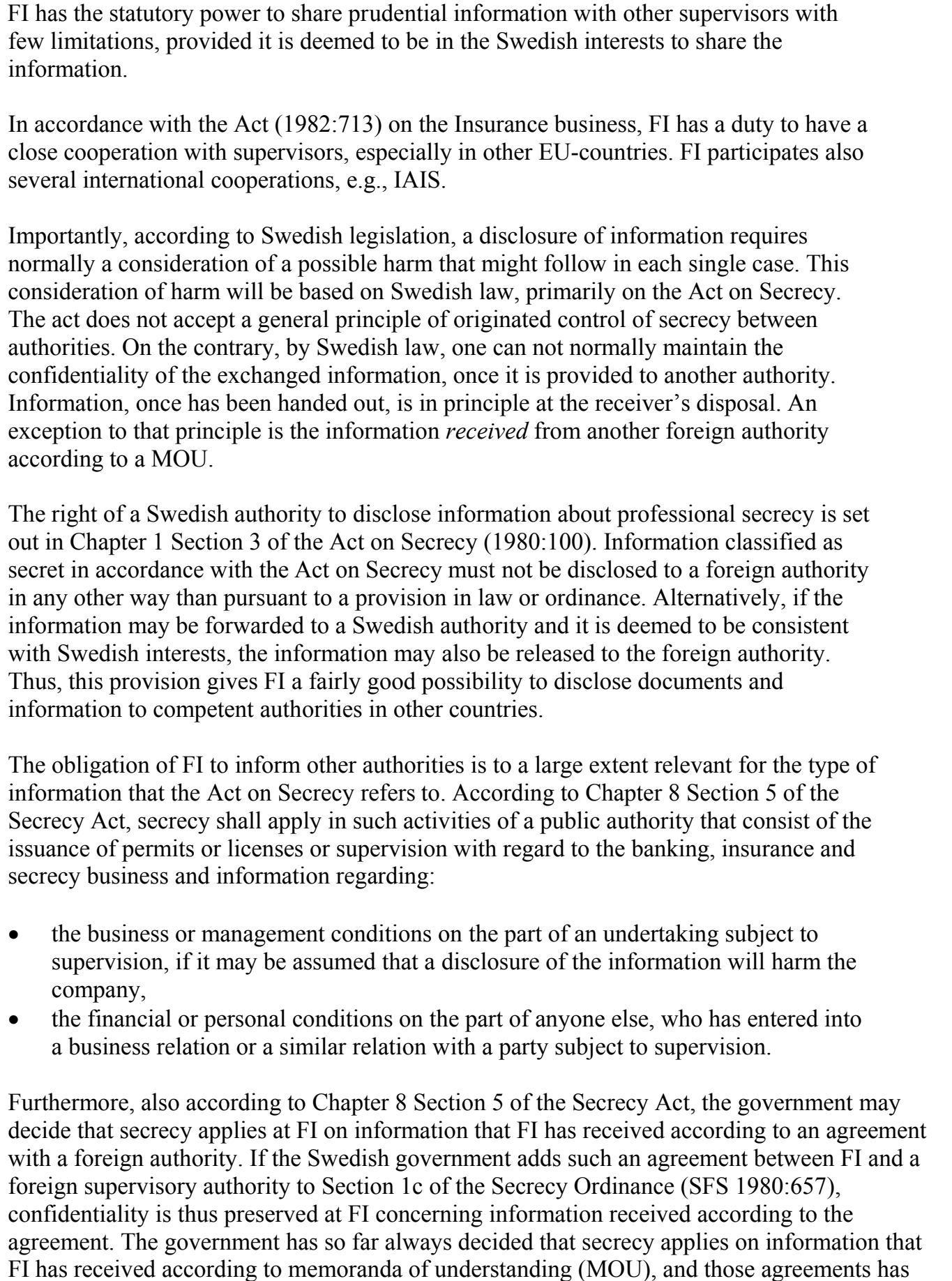 \\
\hline
\end{tabular}




\begin{tabular}{|l|l|}
\hline & $\begin{array}{l}\text { always been added to Section 1c of the Secrecy Ordinance. } \\
\text { The referred provisions in the Act on Secrecy are - according to the Swedish legislators - } \\
\text { applicable to such information that is provided according to provisions based on the EU- } \\
\text { directives. } \\
\text { In insurance there are only a few MOU's. Additionally there are the "Protocol relating to the } \\
\text { collaboration of the supervisory authorities of the member states of the European community in } \\
\text { particular in the application of the directives on life assurance and non-life insurance" and the } \\
\text { so-called "Helsinki-Protocol" concerning insurance groups. According to 1.4 of this agreement } \\
\text { the supervisory authorities has agreed to exchange confidential information whenever possible } \\
\text { within the limits of the rules laid down in the Third Life and Non-life Directives (Articles 16.1 } \\
\text { and 16.2 of the Third Non-life Directive and 15.1 and 15.2 of the Third Life Directive) in order } \\
\text { to improve the effectiveness of insurance supervision in the European Community. }\end{array}$ \\
\hline Broadly observed. \\
\hline $\begin{array}{l}\text { The principle has been implemented by law, MOUs and to some extent by the Protocol. } \\
\text { A case by case approach is more traditionally than general principles. FI has negotiated } \\
\text { several cross-sectoral MOUs with Norway, Baltic countries and Denmark, Finland, } \\
\text { Norway as a group. }\end{array}$ \\
$\begin{array}{l}\text { In order to achieve a completely free exchange of information, including facts that could be } \\
\text { regarded as negative to an institute subject to supervision, not only a certain modification of the } \\
\text { Swedish Act on Secrecy but also an international convention on the subject or a bilateral } \\
\text { agreement between the authorities in different states is required. }\end{array}$ \\
\hline
\end{tabular}

Table 5. Summary Observance of IAIS Insurance Core Principles

\begin{tabular}{|l|l|l|}
\hline \multirow{2}{*}{ Assessment Grade } & \multicolumn{2}{c|}{ Principles Grouped by Assessment Grade } \\
\cline { 2 - 3 } & \multicolumn{1}{|c|}{ Count } & List \\
\hline Observed & 6 & $\mathrm{CP}, 4,5,67,13,16$ \\
\hline Broadly observed & 11 & $\mathrm{CP} 1,2,3,8,8,9,10,11,12,14,15,17$ \\
\hline Materially non-observed & & \\
\hline Non-observed & & \\
\hline Not applicable & & \\
\hline
\end{tabular}




\section{F. Recommended Action Plan and Authorities' Response to the Assessment}

\section{Recommended action plan}

Table 6. Recommended Action Plan to Improve Observance of IAIS Insurance Core Principles

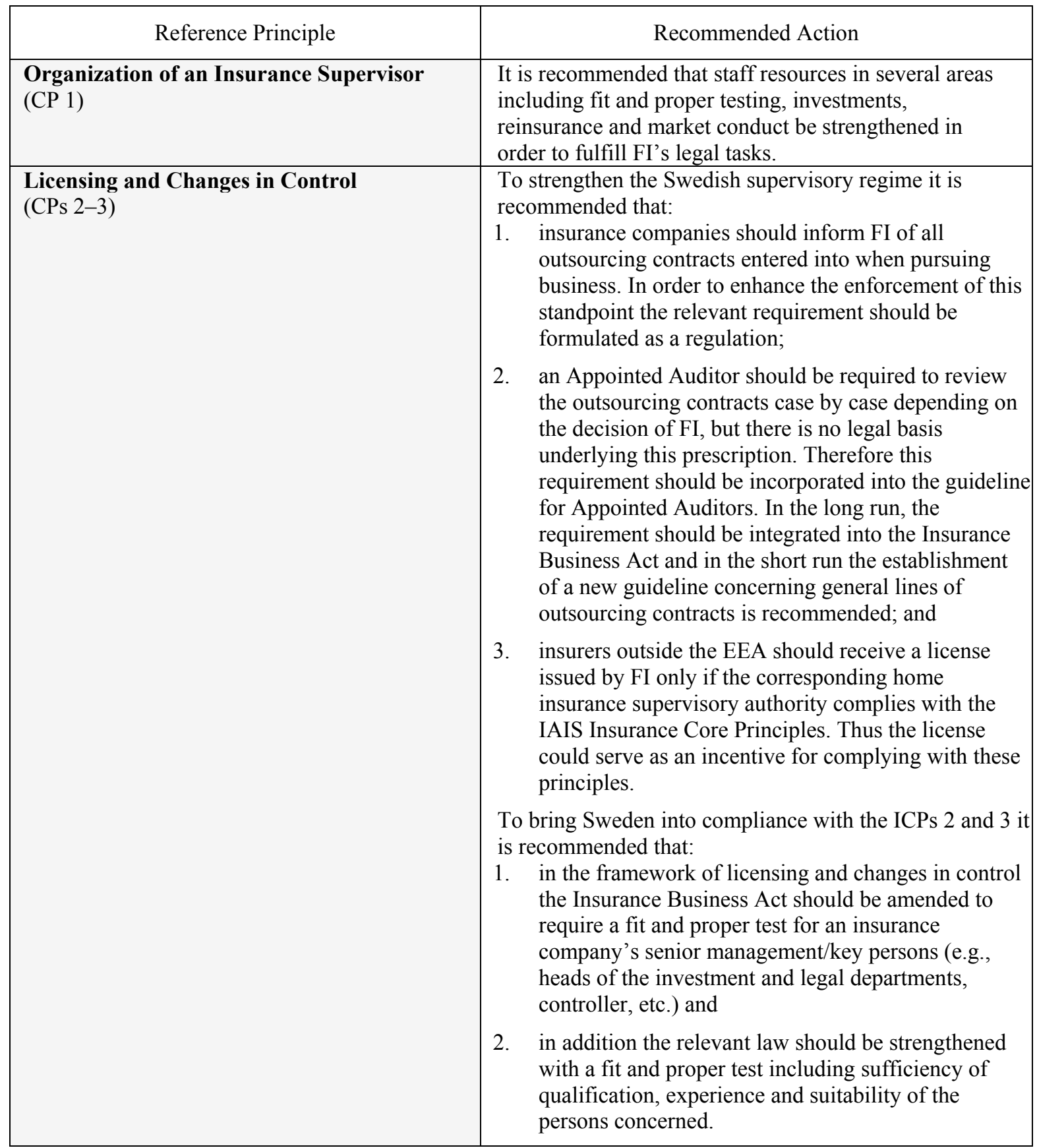




\begin{tabular}{|c|c|}
\hline $\begin{array}{l}\text { Corporate Governance and Internal Controls } \\
\text { (CPs 4-5) }\end{array}$ & $\begin{array}{l}\text { To strengthen the Swedish supervisory regime, it is } \\
\text { recommended that the submission of the insurance } \\
\text { company's annual risk management report to FI should be } \\
\text { mandatory, and that a corresponding prescription into the } \\
\text { Insurance Business Act be implemented. }\end{array}$ \\
\hline $\begin{array}{l}\text { Prudential Rules } \\
\text { (CPs 6-10) }\end{array}$ & $\begin{array}{l}\text { To strengthen the Swedish supervisory regime it is } \\
\text { recommended that in the framework of the analysis of } \\
\text { reserves in non life insurance the distribution-assumption } \\
\text { of a normal distribution should be reviewed for a fitter } \\
\text { distribution, provided the collection of data is } \\
\text { representative for the analysis concerned. } \\
\text { To bring Sweden into observance with CP } 9 \text { it is } \\
\text { recommended that disclosure requirements are } \\
\text { established for derivatives and off-balance sheet items. }\end{array}$ \\
\hline $\begin{array}{l}\text { Market Conduct } \\
\text { (CP 11) }\end{array}$ & $\begin{array}{l}\text { To strengthen the Swedish supervisory regime it is } \\
\text { recommended to establish procedures to ensure that } \\
\text { companies are in compliance with legislation and } \\
\text { guidelines. }\end{array}$ \\
\hline $\begin{array}{l}\text { Monitoring, Inspection, and Sanctions } \\
\text { (CPs 12-14) }\end{array}$ & $\begin{array}{l}\text { To strengthen the Swedish supervisory regime it is } \\
\text { recommended that: } \\
\text { 1. FI should set up a legal basis for the possibility of } \\
\text { issuing a formal criticism in cases where there is a } \\
\text { need for a sharp reprimand rather than obliging a } \\
\text { company to take measures. } \\
\text { 2. the actuarial report be amended: } \\
\text { (a) Life insurance: the Responsible Actuary should take } \\
\text { into account the asset-side when forming an opinion } \\
\text { of the financial status of the insurance company. A } \\
\text { corresponding prescription should be incorporated } \\
\text { into the Insurance Business Act. } \\
\text { (b) Non-life insurance: non-life actuaries are reporting } \\
\text { more about the reserves' development. Hence to } \\
\text { guarantee the quality of the actuarial report, the non- } \\
\text { life Responsible Actuary should sign his report. This } \\
\text { procedure should be prescribed in the form of a FI- } \\
\text { regulation. }\end{array}$ \\
\hline $\begin{array}{l}\text { Cross-Border Operations, Supervisory } \\
\text { Coordination and Cooperation, and } \\
\text { Confidentiality } \\
\text { (CPs } 15-17)\end{array}$ & $\begin{array}{l}\text { To bring Sweden into observance with CP } 15 \text { it is } \\
\text { recommended that appropriate action is taken to see that } \\
\text { branches of Swedish companies in EEA member states } \\
\text { are supervised. } \\
\text { To strengthen the Swedish supervisory regime it is } \\
\text { recommended that Sweden takes measures to maintain } \\
\text { and ensure when shared confidentiality. }\end{array}$ \\
\hline
\end{tabular}




\section{G. Authorities' Response to the Assessment}

45. FI had no specific comments on the detailed assessment and noted that it would do its best to implement the recommendations made in the report as soon as available resources permit.

\section{IOSCO ObJeCtives ANd PRINCIPles OF SECURITIES Regulation}

\section{A. General}

46. The Swedish securities regulatory system was assessed for its observance of the IOSCO Objectives and Principles of Securities Regulation as part of the IMF FSAP mission to Sweden during October and November 2001. The assessment is of the legislative framework, the operations of the securities regulatory authority - FI — and the trading systems and clearing and settlement systems that compose the overall regulatory environment. The assessment was undertaken by Jennifer Elliott.

\section{B. Information and methodology used for the assessment}

47. The assessment is based on interviews with staff of the FI, the MoF, the Stockholmbörsen, the Swedish Central Securities Depository (VPC), the Deposit Guarantee Board, the Mutual Funds Association (MFA) and the SSDA; a review of laws, rules, guidance and procedures with respect to the securities regulatory system (as available in English), relevant EU Directives and proposed EU Directives, and the self-assessments provided by FI, VPC and Stockholmbörsen.

48. The staff of FI accommodated the demand for information and adjusted their schedules to respond in a very timely fashion. FI Staff were candid and forthcoming and were open to discussion of areas where more authority, resources or other enhancements are desirable. Representatives of industry at Stockholmbörsen, VPC, the MFA and the SSDA were also helpful in providing the mission with necessary information.

49. This assessment is primarily an assessment of whether the legal and regulatory framework is in place to meet the requirements of the IOSCO Principles. Because of the limitations on the time available and the type of inquiry, this assessment could not fully evaluate the extent to which the framework in place is implemented by FI programs. This being said, the assessment did attempt to grapple with the extent to which FI implements its policies and procedures and legislation.

50. The assessment is done on the basis of IOSCO's own scale of observanceimplemented, partly implemented, non-implemented and not applicable. 


\section{Structure and role of the securities industry}

51. The Swedish capital markets play a significant role in the Swedish economy. A range of equity, debt and derivatives products are available on the Swedish market. Total market capitalization at the end of 2000 was SKR 3583 billion. Outstanding bonds totaled SKR 1432 billion end-200, of which 725 billion was government paper and 123 billion non-financial enterprises. Outstanding money market securities totaled SKR 448 billion including SKR 271 billion in treasury bills.

52. As a percent age of household savings in Sweden, investments in securities or mutual funds now exceed bank deposits. The value of the equities in Sweden has dropped significantly - the Stockholmbörsen equity index (OMX) is down 50 percent since April 2000. However, investor interest remains high 85 percent of Swedes aged 18-74 are direct investors in mutual funds and 64 percent of Swedish children under 18 hold mutual funds. The number and value of investment has increased due to the recent move by the public pension authority to allow Swedes to invest directly 5 percent of pension contributions in mutual funds and other securities

53. The securities industry is dominated by large market intermediaries - in large part by the four major banks or their subsidiaries. There are 107 licensed investment firms, 20 commercial banks licensed to conduct securities business and 70 savings banks with a more limited securities license (enabling them to process transactions for retail customers) and there are two foreign banks with a license to conduct securities business in Sweden ${ }^{3}$.Of the very largest securities operations, there is only one independent Swedish investment firm. With the decline in the market over the past 18 months, there has been some consolidation in the industry - mergers have consolidated 7 internet trading firms into 2 over the past two years, for example. Commission revenues far outweigh revenue from proprietary trading. Total revenue has declined in 2001 as compared to 2000 remain comparable to 1999.

54. There are 70 fund managers licensed in Sweden. 80 percent of assets under management in the fund industry are managed by mutual fund companies owned and operated by the four large banks.

55. The largest institutional investor in Sweden is the Swedish state-other large investors include the bank-owned mutual funds, the public pension funds, the large banks and insurance companies, foreign mutual funds and a few very large private family holdings. Ownership of public companies is quite transparent relative to other markets - a complete list of shareholders is publicly available and most shares are held directly in the investor's name rather than in nominee name.

${ }^{3}$ These figures supplied by Finansinspektionen and the Mutual Funds Association, as of August 2001. 
56. Sweden's only stock exchange, Stockholmbörsen, a public demutualized exchange, operates a fully electronic equity exchange featuring the SAXESS trading system.

Stockholmbörsen also operates an electronic derivatives exchange offering trading in futures and options and a derivatives clearing and settlement system in which stockholmborsen acts as a central counterparty. The derivatives clearing system offers clearing for trades on the Stockholmbörsen as well as the Oslo Børs, the Copenhagen Exchange and the OM London Exchange and undertakes clearing for custom over-the-counter derivatives. Stockholmbörsen also includes the Fixed Income Exchange-offering trading and trade reporting services for corporate and government bonds. Bond trading can take place through the electronic SOX system, through a more limited transparency electronic dealer system or by telephone with electronic daily reporting. Stockholmbörsen also owns the OM London Exchange. In addition to the Stockholmbörsen, OM AB owns Pulpex - a pulp exchange - and UK PXand electricity market located in London — and Jiway, a dealer market also located in London.

57. The Stockholmbörsen ranks $15^{\text {th }}$ largest stock market in the world, in terms of market capitalization. The exchange handles 6 percent of transaction volume on Europe's listed markets - behind the London Stock Exchange (35.4 percent) and Euronext (24.4 percent).The equity market lists 310 companies with a market capitalizationdeclined in the past two years - of SKR 3.583 billion end-2000. The largest public companies in the OMX include Ericsson, Hennes\&Mauritz, Investor, Telia and the Swedish financial services companies-Skandia, SEB, Nordea and FöreningsSparbanken. Many of these are also listed on other European or American exchanges. Average daily turnover was 224 million trades worth SKR 15.225 billion in September 2001.

58. Equity and debt trades on Stockholmbörsen and the dealer market are cleared and settled through the VPC system which also acts as the securities registry. VPC is effectively controlled by the four major Swedish banks which own 98.6 percent of shares. It is a highly concentrated clearing and settlement system - the same four banks act as marketmakers in the bond and money markets, and act as clearing members for a large number of Swedish and foreign investors, and function as payment banks for most clearing members in the system. Securities are fully dematerialized in Sweden and, unlike in most countries, most Swedes have direct accounts at VPC and hold securities in their own names. Transactions are settled and registered simultaneously. Equity and bond trades are cleared on a $\mathrm{T}+3$ basis, and treasury bills on $\mathrm{T}+2$. The legal framework for clearing and settlement supports extensive use of securities borrowing and lending, finality of settlement and protection of client assets from insolvency. Straight Through Processing has not yet been adopted in Sweden. Unlike the VPC system, the OM Derivatives clearing system acts as a central counterparty.

59. Sweden, more so than many countries, has opened up its border to cross-border trading and financial services activity. Of Stockholmbörsen's 63 members, 30 are remote members without residence in Sweden. These remote members account for 20.8 percent of transactions on the exchange. Stockholmbörsen has entered into the Norex alliance with the Oslo Børs, the Copenhagen Stock Exchange and the Iceland Stock Exchange. The derivatives operations of the Norex alliance are fully integrated - that is trading is accessible to all 
members without cross-membership and clearing is done in each local exchange. This is also the goal of the equity exchange side of the alliance-however, currently cross-membership is required and clearing is not integrated. The Norex member rule book is already substantially harmonized and the exchanges continue to work toward full integration.

60. There are two authorized marketplaces operating in Sweden-Aktietorget Aktiebolag and Nordic Growth Market NGM Aktiebolag - offering trading in small public company shares. The NGM market has recently applied for a license as a stock exchange. There is also an over-the-counter market in equities in Sweden. There are no formal requirements governing trading in this market - an individual investment firm may act as a market maker in an OTC stock, posting a bid and offer prices on its website.

61. The Swedish regulatory system makes extensive use of trade associations for selfregulation - these include the Mutual Funds Association (MFA), the SSDA and the Swedish Industry and Commerce Stock Exchange Committee (NBK). None of these organizations is officially recognized as a self-regulatory organization. The National Board of Consumer Complaints, set up under the Authority, handles consumer complaints on a voluntary basis. Most financial services companies have chosen to use the Board process to address complaints - it acts as an inexpensive and efficient alternative to court actions.

62. The Bank and Finance Bureau, owned by FI, the major banks, the MFA and the SSDA, is responsible for investor education.

\section{General Preconditions for Effective Securities Regulation}

63. The general preconditions for effective securities regulation in Sweden appear to be in place - there are no unnecessary barriers to entry or exit for market participants, competition is encouraged and Sweden's borders are open to foreign participants. The legal system supports effective credit and capital regulation with efficient court systems and bankruptcy law. The legal framework creates a regulator with decision-making authority and supports enforcement of the law.

\section{E. Main Findings}

64. In general the securities regulatory system appears to function smoothly. Legislation and FI rules combine to form a sound basis for regulation and FI enjoys most of the authority it requires over regulated entities. The authority could benefit greatly from additional power to levy fines and other penalties. Were it to take on such activities, FI would have to construct the necessary internal processes to support enforcement activities-such as a hearing system, rules of procedures - and would have to apply additional resources to investigations and enforcement.

65. The challenge FI faces is one of having the resources necessary to implement its many rules and regulations. In recognition of this, FI has recently reorganized its supervision planning. FI has, on the basis of risk to the system, designated 13 institutions or groups of institutions as priorities for supervision. VPC and Stockholmbörsen constitute two of the 
thirteen groups - none of the independent investment firms has been designated but each of the large banks are designated priorities and all of them have securities and mutual fund businesses. The efficacy of this structure cannot be assessed at this time. It is hoped that FI can utilize its unified regulator structure to full advantage in approaching the task.

66. The question of effective implementation underlies most of the findings in the detailed IOSCO Principles assessment. Because FI is short of resources it is not able to carry out in-depth on-site inspections of investment firms or mutual funds. FI's on-site inspections of Stockholmbörsen and VPC are currently very limited and do not cover all relevant risks in clearing and settlement such as legal risk, operational risk, counterparty risk, liquidity risk and systemic risk - although these institutions are considered high priority. FI is addressing the issue of improved supervision of these institutions but it is unclear to what extent on-site inspections are contemplated. FI prefers a risk-based approach to inspections, rather than use of routine inspections - while this approach may make efficient use of limited resources, it is clear that current levels of on-site inspection work is insufficient to gage compliance among market participants. Expertise appears to be lacking in the mutual fund area-detracting from the quality and usefulness of inspections. Expertise is also lacking in the area of clearing and settlement.

67. In general the clearing and settlement systems function smoothly. The OM Derivatives Clearing system is sophisticated and at par with current market practices. The VPC system could seek some improvement. There is a well-functioning and robust securities lending market supported by the legal framework. However, the VPC should improve risk management for clearing and settlement in order to ensure timely settlement in the event that a participant with the largest payment obligation is unable to settle and the VPC should redefine its access criteria for indirect participants. Since the mission visited Sweden in November 2001, we note that the authorities have taken steps to address both of these issues. The legal framework could, however, be improved to bring it in line with other current market practices including repledging of collateral. In addition, the law does not always reflect actual market practice creating a lack of transparency that makes it difficult to assess legal risk.

68. The VPC clearing and settlement system does not adequately prevent an unwinding in the event of the failure of a participant to meet its obligations. This might introduce market risk, liquidity risk and even systemic risk in the event of a bankruptcy of a clearing member or payment bank. The system features an unprotected netting scheme for both equity and debt trade settlements. While a partial guarantee system somewhat mitigates the risks for equity trades, the risk in the debt market is significant. Payment banks are not required to guarantee trades of clearing members who use them as payment banks-leaving open the possibility of a default. The same is true if an indirect participant is not able to deliver the securities-VPC does not act as a central counterparty nor is collateral required to cover the market risk nor are there liquidity arrangements in place to cover liquidity risk. As mentioned, in the event of a large default - for example the failure of one of the clearing members or payment banks - the financial system is at risk. The inadequacy of this system is well-known but FI has been unable to exercise its supervisory authority to solve the problem. 
The perpetuation of this system has removed incentives to participate in the RTGS system, which is underutilized.

69. The unaddressed risks in the VPC system point to shortcomings in the supervision of the VPC system. As with the Stockholmborsen, the importance of the VPC system systemically requires significant attention to its supervision. FI has recently revised its supervisory plan with increased attention to VPC - this supervision plan should include onsite inspections, risk management assessments and a review of the VPC corporate governance structure.

70. FI faces some limitations in responding to regulatory or non-compliance concerns regarding. All material changes to a license are required to be reported and FI has the right to object to the change. FI can also enjoin a regulated entity to cease an activity that contravenes legal requirements (or order the entity to cease operations). However, FI does not have the ability to impose positive actions on a regulated entity and generally applies few conditions to a license. FI cannot change the terms and conditions of a license. Under these limitations FI could not, for example, impose a change in corporate governance structure on VPC or Stockholmbörsen or impose require an investment firm to institute stricter supervision of a particular aspect of its business. Finally, enforcement tools are limited to warnings and revocation of license - there are no fines or penalties and no possibility of settlement agreements.

71. FI does not license individuals nor does it set proficiency requirements for traders, advisors, portfolio managers, compliance officers or officers and directors of the investment firms and mutual fund managers. FI plans to issue general guidelines on proficiency in the near future. Svedsec, a subsidiary of the SSDA, has been set up to register and license individual employees of investment firms. Svedsec — which began operations in April 2001 - sets an examination for individuals and enters them into a public registry. Svedsec has set up a disciplinary committee and can take action against these licensees for a breach of SSDA guidelines or FI regulations. The disciplinary committee may bar an individual from the industry for up to three years.

\section{F. Summary of Principle-by-Principle Assessment}

72. Strength of the regulator-FI is an independent and accountable regulator employing high professional standards - however, FI requires additional resources and authority. More staffing resources are required in order to carry out a more robust on-site inspection program and FI should address the shortage of expertise in some areas (including mutual fund supervision). FI's authority over regulated entities could be strengthened-FI should have the ability to take interim action and should have the power to assess penalties and fines as a result of enforcement actions. FI observes high professional standards and has clear, consistent and transparent processes. FI routinely consults industry and stakeholder groups in implementing rules, makes a great deal of information available on its website and is subject to comprehensive freed of information and privacy laws. FI has the right to share information and has entered into a number of information sharing arrangements. 
73. Self-regulation - The regulatory system in Sweden makes extensive use of Self-Regulatory Organizations (SROs), both formal and informal. The use of SROs is generally in compliance with IOSCO Principles - however, SROs should complement rather than replace regulation by the regulatory authority and, where the SRO is relied on to carry out supervision, that supervision should be subject to vigorous oversight by the regulatory authority. FI's efforts should be strengthened on both counts. Use of the informal SROs to carry out rule development should be balanced by FI's own work on public company and market intermediary regulation.

74. Issuer regulation-Prospectus requirements are in place but monitoring of compliance with the rules is weak for unlisted and $\mathrm{O}$ list securities. Continuous disclosure standards apply only to listed companies and are administered by the Stockholmbörsen. Rule-making initiatives in this area are generated by the industry association NBK and FI does not take a lead role in this area of regulation. Treatment of minority shareholders, stronger for listed companies than unlisted companies, could be improved with greater public float requirements, removal of voting right differentials and stricter take-over bid rules. Administration of these rules should not rest solely with Stockholmbörsen — particularly when the regulatory process is not subject to sufficient oversight. FI will have to revise its approach to these issues in view of the various EU-level initiatives underway- the proposed prospectus and market abuse directives particularly. Accounting standards are high and are moving toward compliance with IASC standards.

75. Mutual fund regulation-Mutual fund licensing requirements are generally satisfactory. Conflicts of interest rules, particularly in a conglomerate setting, could be improved and supervision of mutual funds should be strengthened. The particular problems associated with related depositories should be addressed. FI should give consideration to the consequences of these structures under stressful circumstances. Net asset valuation calculation should be monitored more stringently and there should be rules governing valuation of illiquid securities.

76. Market intermediary regulation-Full licensing and capital adequacy rules are in place for investment firms. FI has supervisory authority over investment firms and may carry out inspections or investigations of these firms. Inspections could be strengthened and the ability to take interim measures against an investment firm would improve FI's ability to enforce compliance with its rules. Capital regulation could be improved with more frequent financial reporting requirements and FI's practical ability to handle the failure of a major investment firm without undue market disruption would be hampered by its limited authority to take positive action. There are gaps in regulation of the client-investment firm relationship and few internal supervisory requirements applicable to investment firms, although most of these gaps will be addressed by proposed EU directives.

77. Marketplaces - FI has taken an advanced approach to marketplace regulationsetting clear and adequate standards for exchanges and alternative trading systems.

Transparency requirements are adequate and rules are in place to detect market abuse. Supervision of the Stockholmbörsen requires improvement. 
78. Clearing and settlement systems - There are weaknesses in the supervision of clearing and settlement systems - both at the Stockholmbörsen and VPC. As a result the lack of adequate risk management for exposures in debt clearing but also in the equity clearing in the VPC system has been allowed to continue. In light of the potential risks these institutions pose to the financial system, serious attention must be given to supervision of the clearing and settlement systems and to addressing the conflicts of interest that arise as a result of the governance structure of both VPC and Stockholmbörsen.

Table 7. Detailed Assessment of Implementation of the IOSCO Objectives and Principles of Securities Regulation

\begin{tabular}{|c|c|}
\hline Principle 1. & The responsibilities of the regulator should be clear and objectively stated. \\
\hline Description & $\begin{array}{l}\text { FI is the sole regulatory authority responsible for regulation of capital markets in Sweden. FI's } \\
\text { responsibilities are clearly set out in legislation and in FI's own regulations. The General } \\
\text { Decree for government Authorities (1995:1322) sets out the framework for independent } \\
\text { government agencies and the Decree with Instruction for FI (1996:596) provides FI with its } \\
\text { general framework and authority. } \\
\text { FI is responsible for prudential and business conduct regulation of market intermediaries, } \\
\text { supervision and regulation of markets, clearing and settlement and central depositories, } \\
\text { regulation of issuers and regulation of investment funds. FI has the right to grant licenses and } \\
\text { also to withdraw licenses. FI is specifically empowered under each separate law and is granted } \\
\text { the right to grant exemptions and issue regulations under each law. Relevant legislation } \\
\text { includes the Financial Instruments Trading Act, Securities Business Act, The Financial } \\
\text { Instruments Accounts Act, The Mutual Funds Act, The Exchange and Clearing Operations Act, } \\
\text { The Capital Adequacy and Large Exposures Act, The Individual Pensions Savings Act, The } \\
\text { Insider Penalty Act, The Reporting Duties Act of Certain Possession of Financial Instruments } \\
\text { and The Finality Act. } \\
\text { As a member of the EU, Sweden has implemented the EU Directives applicable to securities } \\
\text { regulation into its regulations. } \\
\text { As a unified regulator of the financial sector, FI benefits from the synergy created by having all } \\
\text { sector regulators in one organization-within a unified regulator information sharing is } \\
\text { simplified and gaps in jurisdiction are addressed more easily. The recent restructuring of the } \\
\text { organization has the potential to increase these benefits as FI approaches supervision along } \\
\text { functional rather than institutional lines-a reflection of the growing convergence of the sectors } \\
\text { themselves. }\end{array}$ \\
\hline Assessment & Implemented. \\
\hline Comments & $\begin{array}{l}\text { FI's regulatory mandate is clear-no gaps in regulation of the securities markets exist in the } \\
\text { legislation-sole responsibility rests with FI. }\end{array}$ \\
\hline Principle 2. & $\begin{array}{l}\text { The regulator should be operationally independent and accountable in the exercise of its } \\
\text { functions and powers. }\end{array}$ \\
\hline Description & $\begin{array}{l}\text { In the Swedish parliamentary tradition, government agencies-of which FI is one-enjoy } \\
\text { considerable independence. The Swedish constitution explicitly forbids the government or a } \\
\text { Minister from interference from the day-to-day operation of a government agency set up under } \\
\text { the general decree and this appears to be observed in practice. } \\
\text { Each fall the MoF produces a formal mandate for FI. This mandate sets the agency's objectives } \\
\text { for the coming year and is the product of consultation between FI and the Ministry and begins } \\
\text { with a letter of intent from the Director General of FI to the Minister of Finance. FI must also }\end{array}$ \\
\hline
\end{tabular}




\begin{tabular}{|c|c|}
\hline & 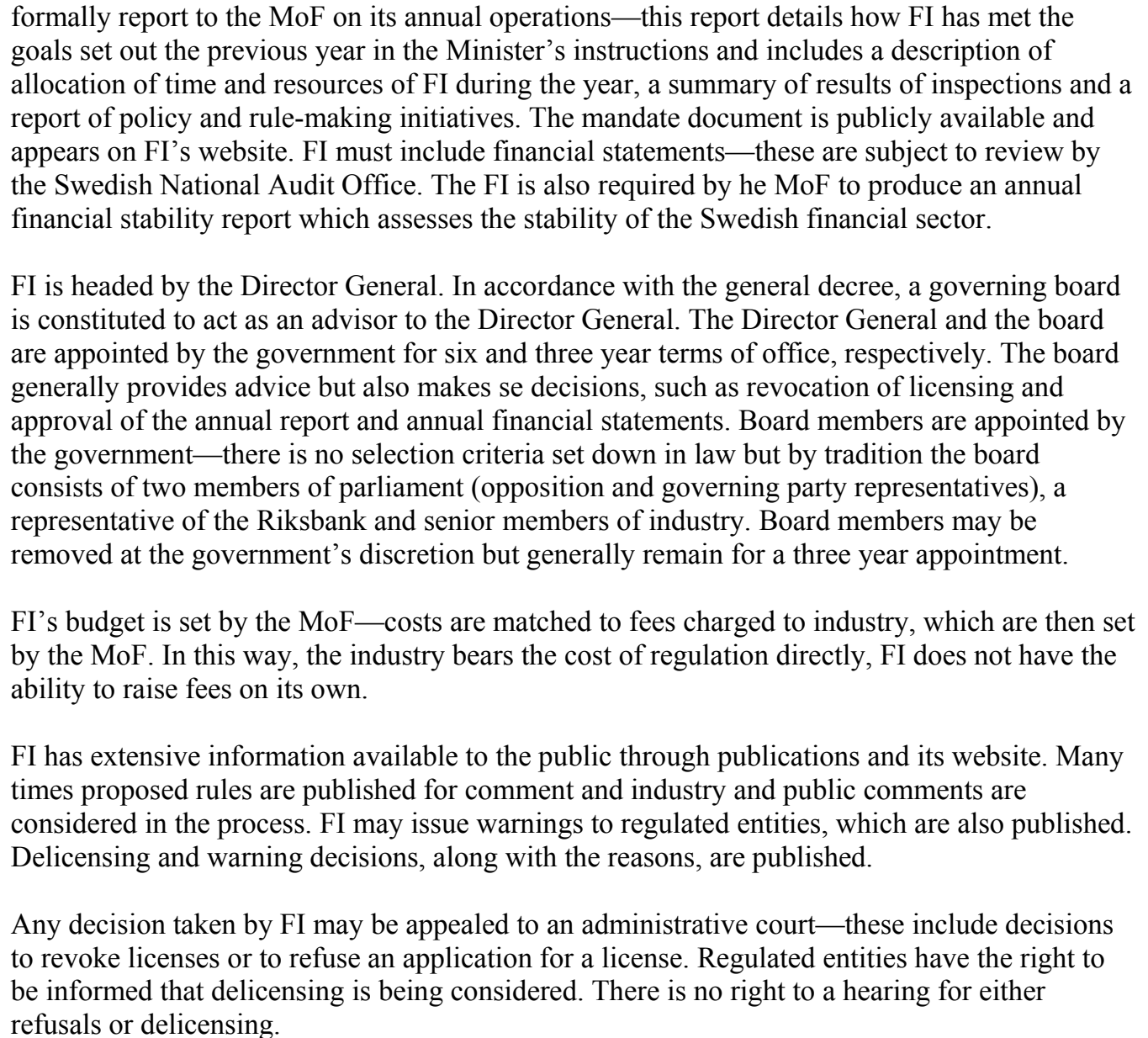 \\
\hline Assessment & Implemented \\
\hline Comments & $\begin{array}{l}\text { Although FI is independent of the MoF, it relies on the ministry for its budget allocation. This is } \\
\text { a limitation on its ability to carry out its mandate independently and the constraint on resources } \\
\text { FI faces under its budget has resulted in shortage of skilled staff, particularly in the area of on- } \\
\text { site inspections (cf. Principles } 7,10,17,18 \text { and } 23 \text { ). } \\
\text { FI is accountable for its activities and decision-making and is transparent in its processes. }\end{array}$ \\
\hline Principle 3. & $\begin{array}{l}\text { The regulator should have adequate powers, proper resources and the capacity to perform its } \\
\text { functions and exercise its powers. }\end{array}$ \\
\hline Description & $\begin{array}{l}\text { FI's authority to regulate is clearly set out in the various pieces of legislation has set up its } \\
\text { operations to address each area. FI has recently undertaken a reorganization designed to deploy } \\
\text { its resources along risk-identified lines. It was difficult to assess the efficacy of this } \\
\text { reorganization during the mission as it was relatively new. FI has skilled and dedicated staff } \\
\text { although it experiences difficulty in retaining and recruiting staff due to an inability to match } \\
\text { private industry salaries and is somewhat constrained by its budget. The mutual funds area, } \\
\text { which is newly placed together with insurance, suffers from a lack of expertise as its current } \\
\text { staff are trained in insurance supervision. There is a need to address this issue, of which FI is } \\
\text { well-aware. } \\
\text { FI has the power to license and delicense regulated entities. FI has complete inspections and } \\
\text { investigations power over regulated entities but does not have the power to compel testimony or } \\
\text { documentation from third parties. FI has the right to object to proposed rules or actions of }\end{array}$ \\
\hline
\end{tabular}




\begin{tabular}{|c|c|}
\hline & $\begin{array}{l}\text { Stockholmbörsen, VPC or the authorized marketplaces but cannot impose a positive action on } \\
\text { these entities. FI has the ability to require financial and other reporting from market } \\
\text { intermediaries and may issue warnings for non-compliance with the law. These warnings are } \\
\text { published. FI can take action against a licensee that has breached the terms of its license, or is in } \\
\text { violation of the rules and regulations, but cannot impose additional conditions on a license } \\
\text { except in limited circumstances. } \\
\text { FI has some control over officers and directors, as they are part of the terms of the license but } \\
\text { FI does not have power over individual employees of licensed firms-individuals are not } \\
\text { subject to licensing. Violations of the law by employees are the responsibility of the licensed } \\
\text { company and FI could not, for example, ban a person from trading although it could pursue the } \\
\text { firm. }\end{array}$ \\
\hline Assessment & Partially implemented \\
\hline Comments & $\begin{array}{l}\text { FI has few tools other than warnings and delicensing with which to exercise its regulatory } \\
\text { powers and must often rely on moral suasion. It has no power to levy fines, suspend a company } \\
\text { or individual's activities, require the regulated entity to institute new policies and procedures or } \\
\text { special supervision, require additional capital, prevent an entity from engaging in expansion of } \\
\text { business during financial distress and so on. Delicensing is a very blunt tool and not particularly } \\
\text { practical in most cases as the winding-up of a market participant is politically difficult, } \\
\text { complicated, dislocating to clients and may have an adverse economic impact. FI's ability to } \\
\text { take interim measures is therefore also limited. Furthermore, FI has no direct regulatory } \\
\text { authority over individuals and is, therefore, denied a range of compliance tools such as levying } \\
\text { fines against individuals, imposing supervision requirements or limiting an individual's } \\
\text { activities for a period of time. }\end{array}$ \\
\hline Principle 4. & The regulator should adopt clear and consistent regulatory processes. \\
\hline Description & $\begin{array}{l}\text { Regulatory processes are clearly set out in legislation and regulations and FI appears to adhere } \\
\text { consistently to established rules and procedures. Processes include licensing, delicensing, } \\
\text { prospectus review and insider reporting. The FI website is comprehensive and contains all of } \\
\text { the relevant information necessary to gain an understanding requirements and procedures. } \\
\text { Investors are referred, through the website or by FI, to the National Consumer Complaint } \\
\text { Board. The website also contains investor education material. } \\
\text { FI has rule-making authority as set out in each specific piece of legislation. FI is not obliged by } \\
\text { law to publish rules for comment but does, in practice, carry out consultations. Industry } \\
\text { associations are specially targeted for consultations- these include the MFA, SSDA, NBK and } \\
\text { the Swedish Shareholders Association. Rules are also forwarded to the National Consumer } \\
\text { Complaint Board and the Consumer Bureau for comment. Once approved, rules are published } \\
\text { on the FI website and time is allowed for implementation. } \\
\text { FI is required to carry out an analysis of the economic impact and cost implications of proposed } \\
\text { rules. This analysis is forwarded to the Swedish National Financial Management Authority, } \\
\text { which, although it may not object to the rule itself, may dispute the economic analysis. FI is } \\
\text { also required to do an impact analysis for each rule concerning its impact on small investment } \\
\text { firms. These analyzes are not published but form part of the consultations with industry groups } \\
\text { and could be requested by a member of the public. } \\
\text { Many requirements applicable to listed companies are found in the listing agreement with the } \\
\text { Stockholmbörsen. Changes to the listing agreement are not published for comment but the } \\
\text { agreement itself is available on the Stockholmbörsen website. The listing agreement } \\
\text { incorporates by reference a number of standards set by NBK--these standards are not published } \\
\text { for comment and not subject to approval by FI. They are published on the NBK and } \\
\text { Stockholmbörsen websites and the development of these standards includes a consultative } \\
\text { process with FI and Stockholmbörsen and the SSDA. Similarly the SSDA and MFA set }\end{array}$ \\
\hline
\end{tabular}




\begin{tabular}{|c|c|}
\hline & $\begin{array}{l}\text { standards for their members, which are often considered binding. There is no public comment } \\
\text { process - however, the standards are publicly available. } \\
\text { FI is required to give reasons for its decision to issue a warning to a licensee or public company } \\
\text { and must give written reasons for delicensing decisions. All warnings and decisions must be } \\
\text { published. Decisions are appealable to an administrative court. FI is required to submit an } \\
\text { annual report to the MoF-the report is made public. }\end{array}$ \\
\hline Assessment & Implemented \\
\hline Comments & $\begin{array}{l}\text { FI has clear and transparent processes - procedures, rules and decisions are all available to the } \\
\text { public. Consultations are undertaken with industry and affected parties and FI is accountable for } \\
\text { its actions through publication and reporting requirements and through the court appeal process. }\end{array}$ \\
\hline Principle 5. & $\begin{array}{l}\text { The staff of the regulator should observe the highest professional standards including } \\
\text { appropriate standards of confidentiality. }\end{array}$ \\
\hline Description & $\begin{array}{l}\text { FI staff are a mix of skilled experts with a broad overall knowledge of supervision. FI makes a } \\
\text { continual effort to recruit staff from among lawyers, accountants and other skilled } \\
\text { professionals. As event from the mission's meetings and interviews with staff, FI's internal } \\
\text { culture is one of professionalism and commitment to high standards. } \\
\text { The Swedish Secrecy Act }(1980: 100) \text { protects confidentiality of information and all FI } \\
\text { employees are bound by the Act. The Act states that information must remain confidential if to } \\
\text { release it would cause the person concerned to suffer a loss if the information is disclosed. } \\
\text { Personal financial information is presumed to be confidential. The Tryckfrihetsoforordinger Act } \\
\text { permits public access to information, including information available from FI. Access under the } \\
\text { Act is very liberal. } \\
\text { FI employees are bounds by the Guidelines for Employees at the Financial Supervisory } \\
\text { Authority which sets out rules governing confidentiality, disqualification, conflicts of interest, } \\
\text { outside employment, trading for personal accounts, accepting gifts and post-employment } \\
\text { confidentiality. There is no similar code of conduct for members of the advisory board although } \\
\text { members of the board may not be employed by, or own a significant share in, a bank or } \\
\text { insurance company. } \\
\text { FI employees are protected from personal liability by the Swedish Employment Standards Law } \\
\text { (need name of it) that ensures that employers are liable for acts of the employee. The employer } \\
\text { can only seek restitution from an employee if there has been gross negligence or bad faith. }\end{array}$ \\
\hline Assessment & Implemented \\
\hline Comments & Standards of professionalism, confidentiality and ethics are very high in Sweden. \\
\hline Principle 6. & $\begin{array}{l}\text { The regulatory regime should make appropriate use of SROs that exercise se direct oversight } \\
\text { responsibility for their respective areas of competence, and to the extent appropriate to the size } \\
\text { and complexity of the markets. }\end{array}$ \\
\hline Description & $\begin{array}{l}\text { The Swedish regulatory system incorporates the use of self-regulatory organizations-both } \\
\text { formal and informal. Applicants for a license are subject to a fit and proper test of owners, } \\
\text { officers and directors. Applicants must show they are capable of carrying out the } \\
\text { responsibilities of a SRO and have the resources to do so. } \\
\text { Stockholmbörsen has responsibility for regulation of its listed companies - it is the sole } \\
\text { regulator of A list stocks, carrying out prospectus review as well as listing requirements. The } \\
\text { exchange is also responsible for the regulation of market conduct, including trading rules and } \\
\text { market surveillance. Stockholmbörsen is a licensed stock exchange under the Securities } \\
\text { Exchanges and Clearing Operations Act (1992:543). It is regulated directly by FI. } \\
\text { Stockholmbörsen is not strictly a SRO since it is a private company that is not owned or } \\
\text { governed by the market intermediaries or listed companies which it regulates. However, }\end{array}$ \\
\hline
\end{tabular}




\begin{tabular}{|c|c|}
\hline & 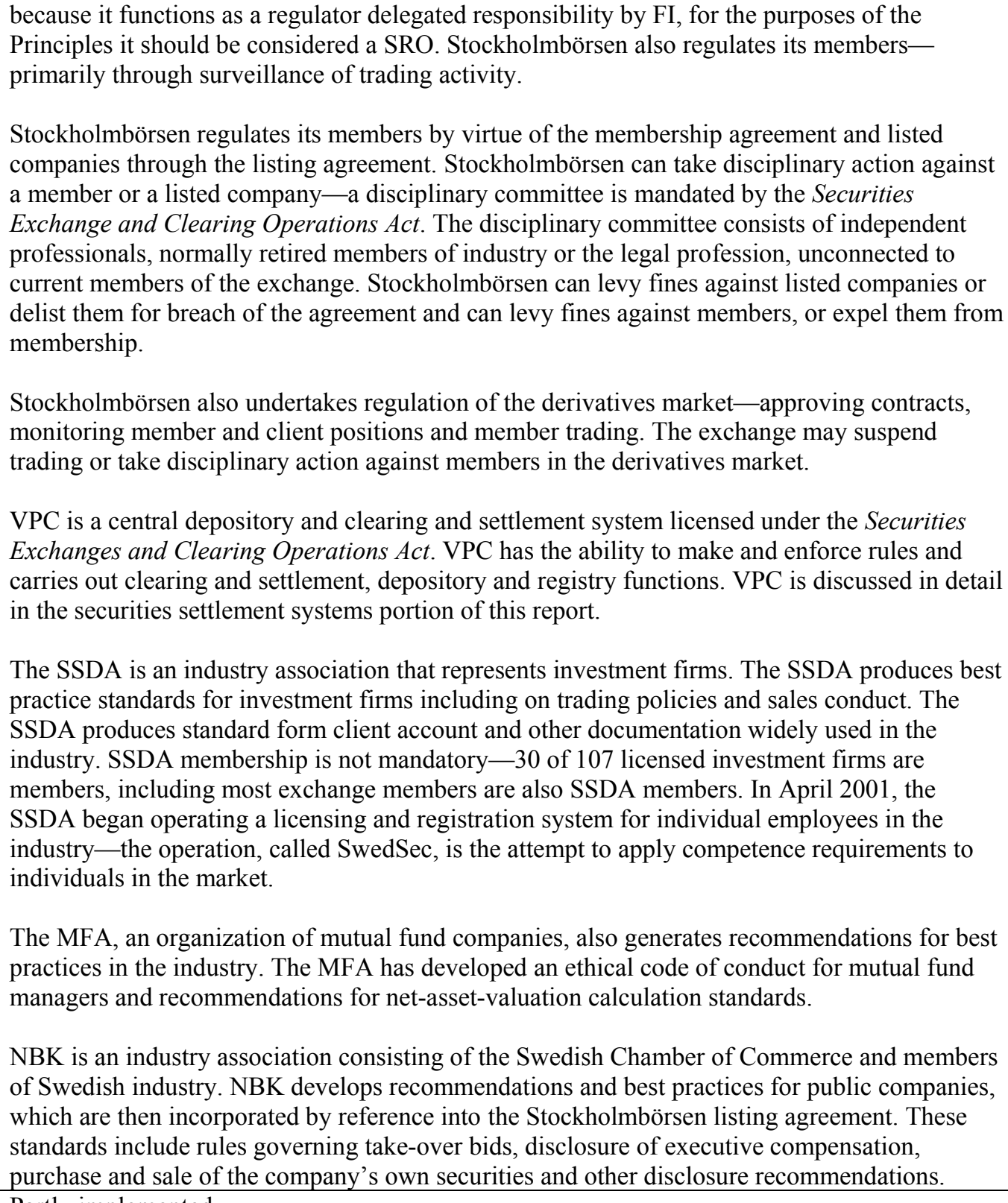 \\
\hline Assessment & Partly implemented \\
\hline Comments & $\begin{array}{l}\text { The reliance on SROs and industry associations to lend their expertise and resources to } \\
\text { regulation of the industry should be balanced with effective oversight that would address the } \\
\text { conflicts of interest inherent in self-regulation or in for-profit regulation. The oversight of VPC } \\
\text { and Stockholmbörsen require strengthening and are discussed in detail under Principle } 7 \text {. } \\
\text { While the input and expertise of the industry associations is valuable and these organizations } \\
\text { appear to be committed to appropriate regulatory standards, there is a very heavy reliance on } \\
\text { these organizations, which may not be appropriate for unsupervised and informal SROs. } \\
\text { Detailed regulation of market intermediaries, where it is found, has been left to the SSDA to fill } \\
\text { in and these rules are not subject to FI approval. }\end{array}$ \\
\hline
\end{tabular}




\begin{tabular}{|c|c|}
\hline & $\begin{array}{l}\text { troubling. NBK is not supervised by FI and its rules are not subject to approval and yet they are } \\
\text { incorporated in the listing agreement, which forms the basis for most issuer regulation after the } \\
\text { prospectus is approved. FI itself has not been active in rule making and policy making related to } \\
\text { public company regulation and, therefore, the industry has set the agenda for new regulation. } \\
\text { FI's lack of activity in this area-with almost all issuer regulation taking place at NBK and } \\
\text { Stockholmbörsen - undermines its ability to develop expertise and depth of understanding. }\end{array}$ \\
\hline Principle 7. & $\begin{array}{l}\text { SROs should be subject to the oversight of the regulator and should observe standards of } \\
\text { fairness and confidentiality when exercising powers and delegated responsibilities. }\end{array}$ \\
\hline Description & 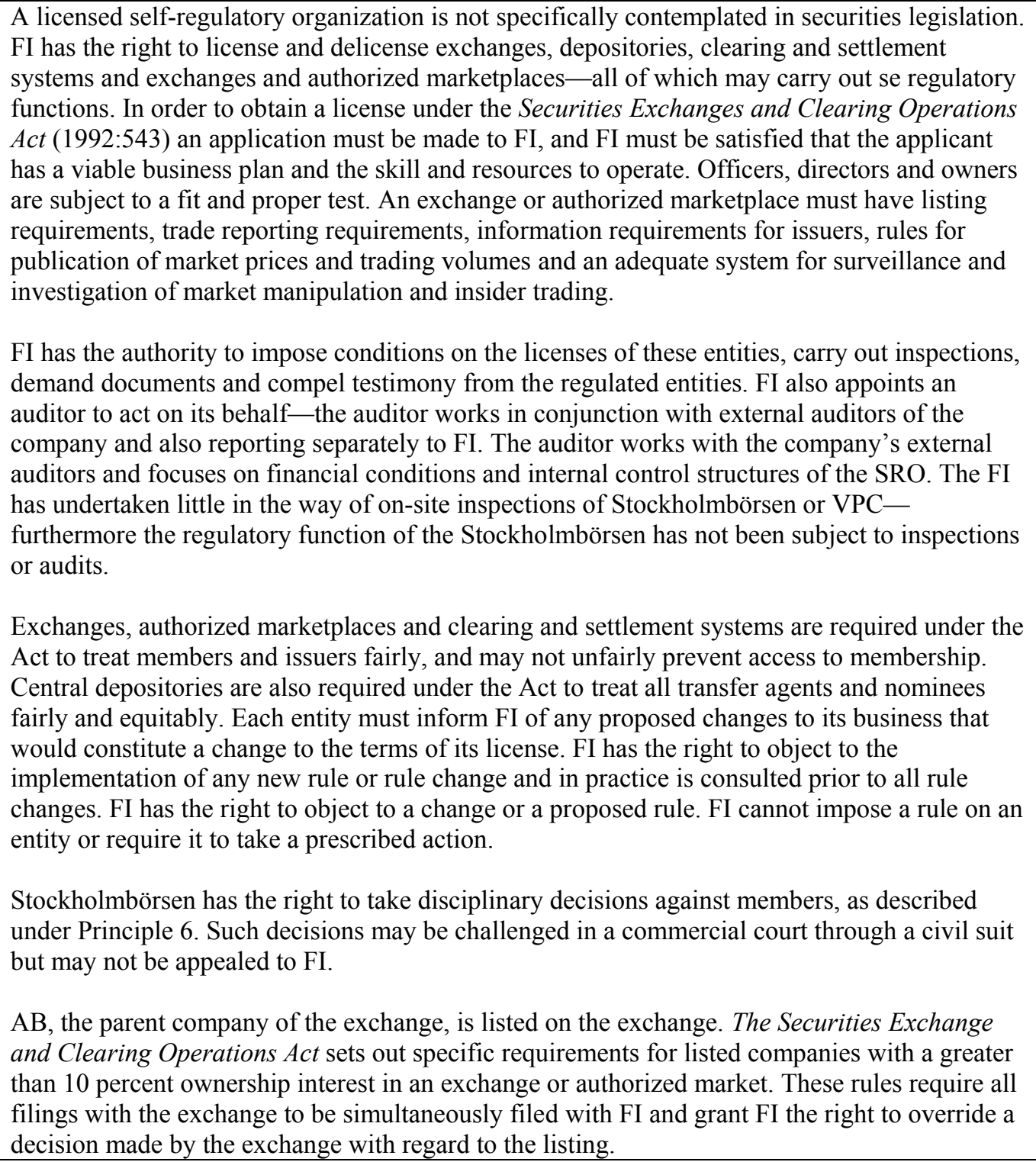 \\
\hline Assessment & Partly implemented \\
\hline Comments & $\begin{array}{l}\text { Stockholmbörsen is one of the key participants in the Swedish financial market and has been } \\
\text { identified as one of the thirteen most important areas in FI's area of responsibility. Its } \\
\text { importance to the system should be reflected in the level of supervision. The risks inherent in a } \\
\text { for-profit entity that regulates its own customers in a very competitive environment should be } \\
\text { considered in the inspection program and in FI's reliance on Stockholmbörsen generally. }\end{array}$ \\
\hline
\end{tabular}




\begin{tabular}{|c|c|}
\hline & $\begin{array}{l}\text { There are few controls in place to mitigate against conflicts of interest. FI does not carry out } \\
\text { extensive inspections of Stockholmbörsen and its auditors do not focus on Stockholmbörsen's } \\
\text { regulatory responsibilities. There is no independent governance requirement for } \\
\text { Stockholmbörsen's board. There are few reporting requirements although FI staff conduct } \\
\text { monthly meetings with the exchange. The exchange's regulatory functions are not separated } \\
\text { from the general business of the exchange. Stockholmbörsen's disciplinary decisions are not } \\
\text { appealable to FI. Stockholmbörsen is required to have sufficient capital - although the level is } \\
\text { not prescribed, FI is involved in discussions when changes to the level are proposed. As with all } \\
\text { regulated entities, FI has limited authority to impose an action on Stockholmbörsen but relies } \\
\text { on its powers of objection, and its ability to issue a warning. } \\
\text { It is strongly recommended that FI significantly increase its supervision of the exchange } \\
\text { including staff-led inspections of its regulatory functions. }\end{array}$ \\
\hline Principle 8. & The regulator should have comprehensive inspection, investigation and surveillance powers. \\
\hline Description & $\begin{array}{l}\text { Under the Securities Business Act, FI has the right to carry out inspections of all investment } \\
\text { firms. FI has the right to require production of documents, enter premises and compel } \\
\text { testimony. FI also has the authority to appoint an auditor for all regulated entities-the auditor } \\
\text { is responsible to FI and paid for by the regulated entity. Under the Securities Exchange and } \\
\text { Clearing Operations Act, FI has the same authority overt exchanges, marketplaces and clearing } \\
\text { and settlement systems and under the Mutual Funds Act, FI has the same authority over mutual } \\
\text { fund managers. Under the Securities Business Act, FI can bring an injunction against an } \\
\text { unlicensed entity carrying on a securities business and levy a fine against the entity. } \\
\text { FI does not have the authority to compel testimony or documentation from a third party-that is } \\
\text { a company or individual not regulated by FI. This limits FI's ability to pursue market } \\
\text { manipulation and insider dealing cases. FI has no direct authority of individual employees of } \\
\text { regulated entities- documents and testimony can be compelled through the employer but if the } \\
\text { employee has already left the firm, FI has no recourse. The public prosecutor has full power of } \\
\text { the state to compel evidence but the matter must proceed to a prosecution first. } \\
\text { The Stockholmbörsen has the authority to investigation and compel evidence from its members } \\
\text { pursuant to its membership agreement. Stockholmbörsen also has the authority to investigate } \\
\text { registered traders pursuant to their agreements with the exchange. }\end{array}$ \\
\hline Assessment & Implemented \\
\hline Comments & $\begin{array}{l}\text { FI has authority to carry out inspections, surveillance and investigations of its regulated entities. } \\
\text { It's capacity to implement effective inspections and investigations are discussed under market } \\
\text { intermediaries, mutual funds and trading rules. FI does not, however, have sufficient authority } \\
\text { over individuals who are not regulated or individual employees. }\end{array}$ \\
\hline Principle 9. & The regulator should have comprehensive enforcement powers. \\
\hline Description & $\begin{array}{l}\text { FI has the authority to enforce compliance with the law by all regulated entities. Under the EU } \\
\text { Investment Services Directive ( } 93 / 22 \text { EEC) FI also has responsibility for enforcement of cross- } \\
\text { border activity of Swedish licensees. FI has the power to issue a warning or withdraw a license } \\
\text { in the case of non-compliance with the law and may suspend trading in a security. } \\
\text { FI has no jurisdiction over unregulated entities or persons and cannot compel testimony or } \\
\text { documentation from these persons for the purpose of investigations. A criminal prosecutor can, } \\
\text { however, compel testimony or production of documents from anyone and actions against third } \\
\text { parties may be referred to the public prosecutor. FI does not act as a tribunal-it does not hold } \\
\text { hearings and cannot levy fines, suspend trading rights or suspend activities of regulated entities. } \\
\text { Exceptions to this are FI's ability under the Reporting Obligations for Certain Holdings of } \\
\text { Financial Instruments Act to levy fines against individuals who fail to report holdings and } \\
\text { insider trades as required under that act and its authority to address unlicensed. }\end{array}$ \\
\hline
\end{tabular}




\begin{tabular}{|c|c|}
\hline & $\begin{array}{l}\text { Prosecutions are undertaken by the public prosecutor. As discussed under Principle 2, FI has } \\
\text { limited power to enforce compliance with its rules. }\end{array}$ \\
\hline Assessment & Partly implemented. \\
\hline Comments & $\begin{array}{l}\text { FI does not have the power to impose fines or take actions against individuals or regulated } \\
\text { entities. It has no power to bring an action against a third party and must rely on a criminal } \\
\text { prosecution by the public prosecutor. Because FI does not license individual traders or } \\
\text { salespersons, its ability to directly address non-compliance by individuals is further limited. }\end{array}$ \\
\hline Principle 10. & $\begin{array}{l}\text { The regulatory system should ensure an effective and credible use of inspection, investigation, } \\
\text { surveillance and enforcement powers and implementation of an effective observance program. }\end{array}$ \\
\hline Description & 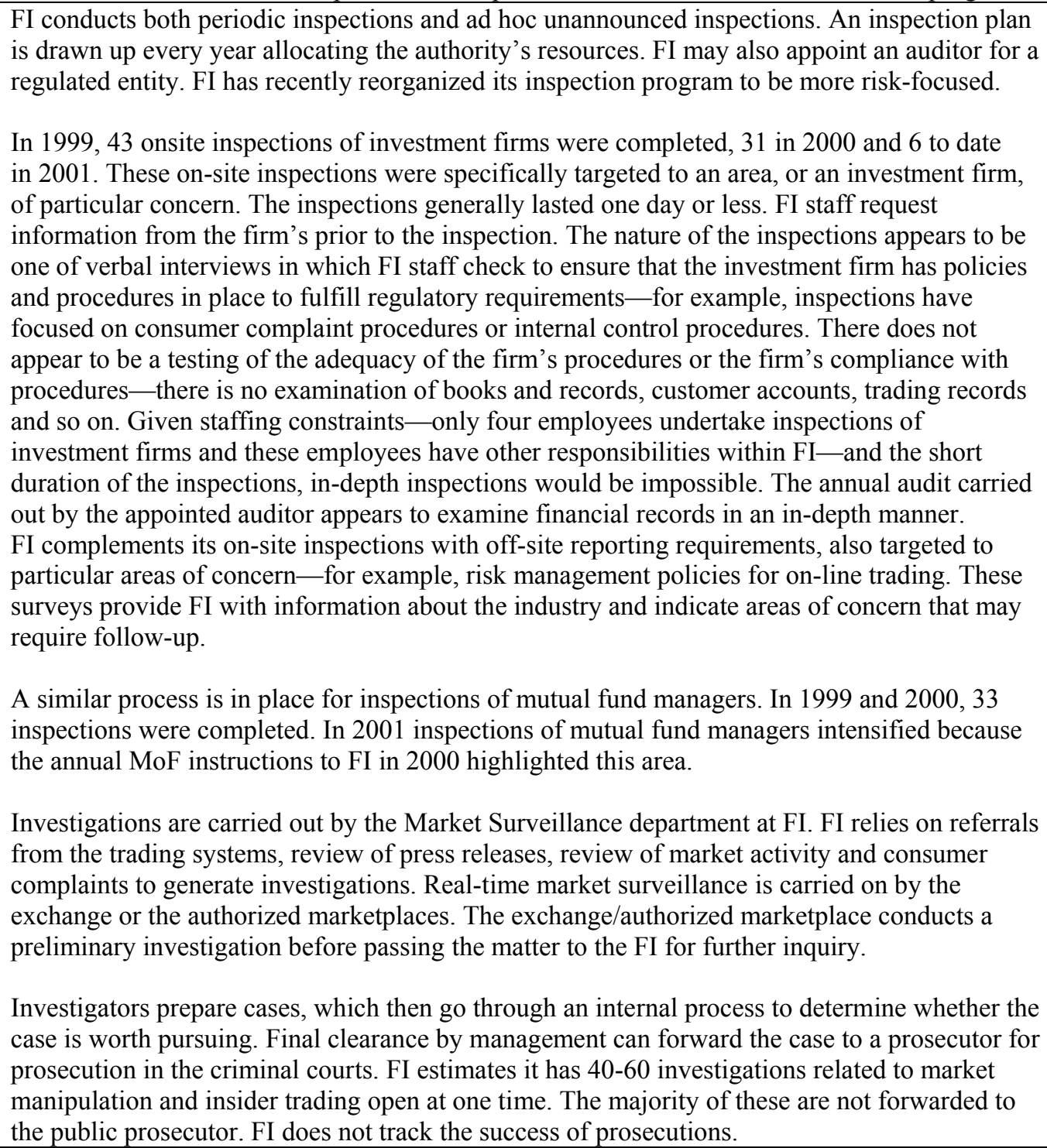 \\
\hline Assessment & Partly implemented \\
\hline Comments & $\begin{array}{l}\text { FI's investigation function is limited by its enforcement mandate- there are few options other } \\
\text { than prosecution and thus most issues are handled not through a formal investigation process } \\
\text { but rather through staff dealings with market participants. Were FI granted authority to levy } \\
\text { fines and impose other penalties on market intermediaries and public companies, the } \\
\text { investigations function would have to expand accordingly and a full hearing process develop at } \\
\text { the FI. }\end{array}$ \\
\hline
\end{tabular}




\begin{tabular}{|c|c|}
\hline & $\begin{array}{l}\text { Although FI has the authority to carry out inspections, there is se concern that resources are } \\
\text { inadequate to properly engage in an effective inspection program. Inspections do not involve a } \\
\text { detail review of a firm's compliance with requirements-generally, they focus on whether } \\
\text { procedures are in place rather than whether such procedures are successfully executed. The } \\
\text { industry associations expressed a concern about the adequacy of examinations. The MFA, in } \\
\text { particular, felt that more in-depth inspections are required. The MFA, as well as FI staff, } \\
\text { expressed concerns regarding the lack of expertise in mutual fund regulation. Staff in the } \\
\text { mutual fund area do not have a depth of mutual funds expertise. }\end{array}$ \\
\hline Principle 11. & $\begin{array}{l}\text { The regulator should have authority to share both public and non-public information with } \\
\text { domestic and foreign counterparts. }\end{array}$ \\
\hline Description & $\begin{array}{l}\text { FI has the authority to enter into information sharing agreements with domestic and foreign } \\
\text { agencies and may share both public and non-public information. All such agreements must be } \\
\text { approved by the government. The Secrecy Act applies to information that is provided under } \\
\text { such agreements and also applies to information FI receives from counterparts under an } \\
\text { agreement. Chapter } 14 \text { of the Act sets out situations in which information is not protected-for } \\
\text { example information must be provided where there is suspicion of crime or in cooperation with } \\
\text { parliament or the government. }\end{array}$ \\
\hline Assessment & Implemented \\
\hline Comments & $\begin{array}{l}\text { FI has the ability to enter into information sharing arrangements and the parameters for this are } \\
\text { clearly established in The Secrecy Act. }\end{array}$ \\
\hline Principle 12. & $\begin{array}{l}\text { Regulators should establish information sharing mechanisms that set out when and how they } \\
\text { will share both public and non-public information with their domestic and foreign counterparts. }\end{array}$ \\
\hline Description & $\begin{array}{l}\text { FI has entered into information sharing agreements with the Swedish Consumer Agency, the } \\
\text { National Board for Consumer Complaints and the Deposit Guarantee Board. These agreements } \\
\text { set out the terms under which FI will provide information to these domestic counterparts and } \\
\text { the terms under which FI can request information. } \\
\text { FI has entered into information sharing agreements with each of the EU members and Latvia- } \\
\text { the standard MOU sets specific criteria for what kind of information can be provided and to } \\
\text { what use it may be put. FI has a similar MOU with Council of European Securities Regulators } \\
\text { (CESR). FI is hoping to expand its information sharing arrangements to the Baltic countries. }\end{array}$ \\
\hline Assessment & Implemented \\
\hline Comments & $\begin{array}{l}\text { FI has been active in establishing information sharing arrangements with its European } \\
\text { counterparts and with domestic agencies. }\end{array}$ \\
\hline Principle 13. & $\begin{array}{l}\text { The regulatory system should allow for assistance to be provided to foreign regulators who } \\
\text { need to make inquiries in the discharge of their functions and exercise of their powers. }\end{array}$ \\
\hline Description & $\begin{array}{l}\text { FI endeavors to honor information requests from other regulators. The Secrecy Act governs } \\
\text { what information can be shared with foreign regulators-under the Act FI must balance the } \\
\text { interest of confidentiality with the interests of the requesting regulator. A formal analysis is } \\
\text { performed by staff before information can be released. }\end{array}$ \\
\hline Assessment & Implemented \\
\hline Comments & $\begin{array}{l}\text { FI has provided information to a number of regulators involved in investigations and licensing } \\
\text { processes. FI has close relationships with European regulators and also provides information to } \\
\text { the U.S. SEC. }\end{array}$ \\
\hline Principle 14. & $\begin{array}{l}\text { There should be full, accurate and timely disclosure of financial results and other information } \\
\text { that is material to investors' decisions. }\end{array}$ \\
\hline Description & $\begin{array}{l}\text { Prospectus disclosure rules for issuers are set down in Financial Instruments Trading Act } \\
\text { (1991:980) incorporating the EU Public Offers Directive (89/390/EEC). Prospectus rules set out } \\
\text { minimum disclosure to investors. The rules require a signed auditor's statement but do not } \\
\text { require an underwriter's certification. The Annual Report Act (1995:54) sets out requirements } \\
\text { for annual reports for all public companies. }\end{array}$ \\
\hline
\end{tabular}




\begin{tabular}{|c|c|}
\hline & 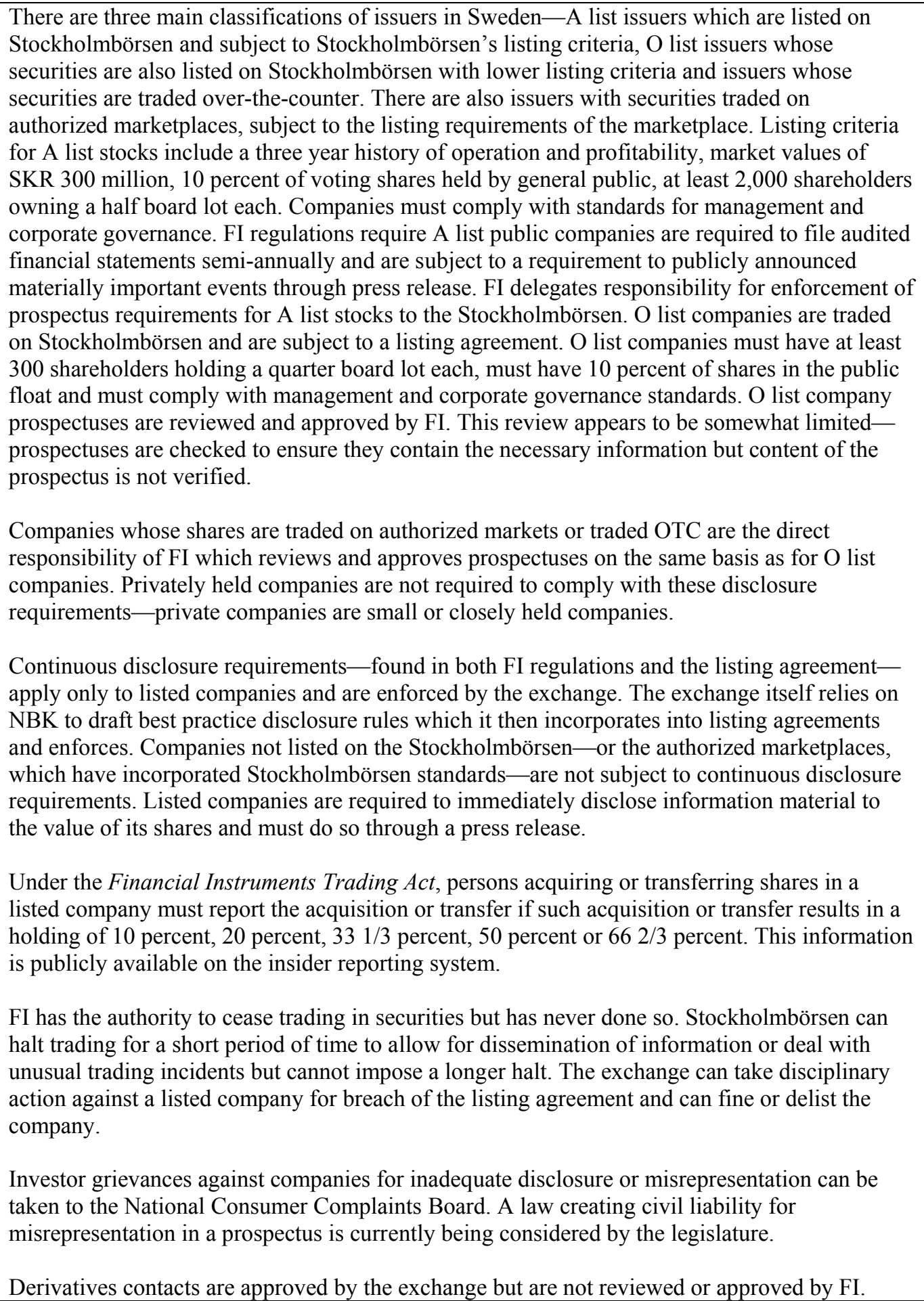 \\
\hline Assessment & Partly implemented \\
\hline Comments & $\begin{array}{l}\text { Prospectus disclosure requirements meet European and international standards-although the } \\
\text { level of prospectus review appears to be limited for O list and OTC traded companies. } \\
\text { However, continuous disclosure requirements apply only to companies listed on the } \\
\text { Stockholmbörsen or an authorized marketplace. Furthermore, there is an undue reliance on }\end{array}$ \\
\hline
\end{tabular}




\begin{tabular}{|c|c|}
\hline & $\begin{array}{l}\text { Stockholmbörsen and the industry association to set and enforce continuous disclosure. As } \\
\text { stated under Principle } 7 \text { this reliance is very heavy in proportion to the oversight } \\
\text { Stockholmbörsen currently receives and there is no direct supervision of the industry } \\
\text { association. Furthermore, FI staff appear to have little involvement in generating policy } \\
\text { initiatives in this area. } \\
\text { Proposed EU directives on market abuse and prospectus disclosure will challenge the Swedish } \\
\text { system-the proposals envision one central authority in each country responsible for issuer } \\
\text { regulation and the proposals do not support reliance on an exchange. Continuous disclosure } \\
\text { requirements will also be strengthened under proposed directives. }\end{array}$ \\
\hline Principle 15. & Holders of securities in a company should be treated in a fair and equitable manner. \\
\hline Description & $\begin{array}{l}\text { The Company Act (1975:1385) provides that all shareholders must be treated in a fair and } \\
\text { equitable matter and governs shareholder meetings, notice to shareholders and the right of } \\
\text { minority shareholders to require an extraordinary shareholders' meeting. Minority shareholders } \\
\text { can request an auditor. The Company Act also governs oppression rules and is not administered } \\
\text { by FI. The insider trading registry available at FI is also helpful to minority shareholders. } \\
\text { Shares commonly have different voting rights although this has improved in recent years- the } \\
\text { differential is now generally } 10 \text { to } 1 \text { rather than, in the past, as much as } 1000 \text { to } 1 \text {. New } \\
\text { companies are required to keep within a } 10 \text { to } 1 \text { differential and FI hopes to more toward equal } \\
\text { voting rights for all shares. A listed company is required to have } 10 \text { percent of its shares in the } \\
\text { public float. A shareholder registry is publicly accessible and displays the names of all } \\
\text { shareholders. Listed companies are subject to various continuous disclosure requirements under } \\
\text { the listing agreement and must immediately announce material information. } \\
\text { Take-over bid rules, drafted by NBK and incorporated by reference into the listing agreement, } \\
\text { are a recent innovation in Sweden. A shareholder that acquires } 40 \text { percent of outstanding shares } \\
\text { must make a bid for all outstanding shares. The listing agreement set standards for valuation of } \\
\text { non-arm's length transactions and other protections for minority shareholders. NBK rules are } \\
\text { not binding on companies that are not subject to listing agreements. } \\
\text { There are no laws requiring shareholders who hold shares in nominee name to receive } \\
\text { disclosure documents. However, this appears to be a minor issue given the unique nature of } \\
\text { Sweden's shareholder registration. }\end{array}$ \\
\hline Assessment & Partly implemented \\
\hline Comments & $\begin{array}{l}\text { Sweden could improve its treatment of minority shareholders. Shareholders are entitled to } \\
\text { ownership in information through the shareholder registry and through disclosure requirements. } \\
\text { While minority shareholders enjoy rights under the law, including right to require an audit in } \\
\text { special circumstances, there is still a pattern of majority control of voting rights through the } \\
\text { differential in voting rights attached to shares and there is a very low threshold of public float } \\
\text { for listing on the exchange. Take-over bid rules also set a high threshold. } \\
\text { There is an almost complete lack of involvement in this area of regulation by FI. The reliance } \\
\text { on an industry association to set and the exchange to administer, timely and selective } \\
\text { disclosure, take-over bid standards and non-arm's length transaction rules may not } \\
\text { appropriate--there is significant potential for conflicts of interest. }\end{array}$ \\
\hline Principle 16. & Accounting and auditing standards should be of a high and internationally acceptable quality. \\
\hline Description & $\begin{array}{l}\text { The rules for the public accounting of companies such as annual reports, consolidated accounts } \\
\text { and interim reports are spread out in several separate laws. Securities firms must comply with } \\
\text { FI's own rules for financial reporting as well as general accounting law. FI rules have comply } \\
\text { with the accounting directives of EU (the fourth and seventh accounting directive and also the } \\
\text { banking and insurance directive). }\end{array}$ \\
\hline
\end{tabular}




\begin{tabular}{|c|c|}
\hline & $\begin{array}{l}\text { The Annual Accounts Act (1995:1554) stipulates the fundamental principles for the preparation } \\
\text { of annual accounts. The Swedish Financial Accounting Standards Council creates additional } \\
\text { guidelines and standards. } \\
\text { Swedish GAAP does not yet comply with IAS standards-although IAS standards are } \\
\text { applicable to listed companies through the exchange listing agreements. The proposed EU } \\
\text { directive on accounting standards will impose IAS standards for consolidated statements for } \\
\text { listed companies in } 2005 \text {. The current proposal for unlisted issuers would give the he country } \\
\text { the option of requiring those companies to comply with IAS standards or not. Sweden proposes } \\
\text { to impose the IAS evaluation standards on unlisted companies but not require them to make the } \\
\text { same disclosures to shareholders required of listed companies. } \\
\text { Under the Company Act, all public companies must employee an independent auditor. New } \\
\text { legislation to come into force on January } 1,2002 \text { will set more specific standards of } \\
\text { independence. FI also sets additional requirements for auditors of investment firms. } \\
\text { Issuers are not required to have audit committees. }\end{array}$ \\
\hline Assessment & Implemented \\
\hline Comments & $\begin{array}{l}\text { Listed companies are subject to IAS standards and requirements for unlisted issuers currently } \\
\text { comply with EU standards. Auditors are required to be independent. Accounting and audit } \\
\text { standards for investment firms and mutual fund managers are extensive. }\end{array}$ \\
\hline Principle 17. & $\begin{array}{l}\text { The regulatory system should set standards for the eligibility and the regulation of those who } \\
\text { wish to market or operate a collective investment scheme. }\end{array}$ \\
\hline Description & $\begin{array}{l}\text { The Mutual Funds Act (1990:1114) sets out requirements for the operation of mutual funds in } \\
\text { Sweden. In order to solicit business from Swedish customers, a fund must comply with EU } \\
\text { Directive 85/611/EEC for UCIT funds or must comply with requirements set out in the Act- } \\
\text { these are national or non-UCIT funds. } \\
\text { In order to obtain a license, a mutual fund company must be a limited company with a } \\
\text { minimum capital of SKR } 1 \text { million. The fund company must show that the officers and } \\
\text { directors of the company have the proper education, skills and experience to administer a fund. } \\
\text { All changes to ownership require approval of FI. Owners are, however, not subject to fit and } \\
\text { proper assessments. There are no proficiency standards for asset managers-although there is a } \\
\text { fit and proper assessment of individual officers. The Mutual Fund Act and FI's Mutual Fund } \\
\text { Regulation (FFFS 1997:11) set out ethical guidelines and disclosure requirements for mutual } \\
\text { funds. The fund company is required to set out details of its rules and regulations- these rules } \\
\text { are approved by FI at the time of licensing and form the basis of disclosure to investors. The } \\
\text { rules of the fund must include terms of redemption, investment strategy, risk management } \\
\text { measures and basis of net asset value calculations. } \\
\text { FI regulations require the mutual fund company to have an independent annual auditor, } \\
\text { establish rules and regulations for the responsibilities within the company (FFFS } 1999: 12 \text { ) and } \\
\text { establish procedures for handling unit-holders' complaints (FFFS 1996:25). Mutual fund } \\
\text { companies are required to report annually and semi annually. } \\
\text { The Mutual Funds Act prohibits trading between the fund and insiders of the fund but does not } \\
\text { prohibit or restrict trading with related companies. The Act also sets limits on leverage, } \\
\text { depository requirements and exposure limits. There are no restrictions on lending to related } \\
\text { companies. The MFA sets voluntary ethical rules which include standards for conducting } \\
\text { business through a related company. } \\
\text { FI appoints outside auditors for each mutual fund company. This auditor is responsible for } \\
\text { participation in the company's annual audit and FI is currently undertaking a series of on-site } \\
\text { inspections of mutual funds-focusing on internal controls and disclosure to clients. A report on }\end{array}$ \\
\hline
\end{tabular}




\begin{tabular}{|c|c|}
\hline & $\begin{array}{l}\text { findings from these inspections is to be made in December. FI has the right to appoint an auditor, } \\
\text { at the mutual funds expense, the auditor takes part in the fund's annual external audit. The auditor } \\
\text { is given explicit instructions from FI concerning what specific issues FI would like addressed. } \\
\text { UCIT funds are-subject to the he country laws and inspections by the he country regulator. FI } \\
\text { does not establish a relationship with the he country regulator with the introduction of a UCIT } \\
\text { fund to the Swedish market but generally has good relations with other European regulators. } \\
\text { Foreign companies operating in Sweden do not have to open a branch office in Sweden but } \\
\text { must appoint a paying agent. In addition, Swedes may purchase mutual funds from other } \\
\text { jurisdictions and those funds are not subject to Swedish regulation unless the funds actively } \\
\text { solicit in Sweden. }\end{array}$ \\
\hline Assessment & Partly implemented. \\
\hline Comments & $\begin{array}{l}\text { Conflicts of interest should be dealt with more comprehensively. There are few requirements } \\
\text { governing the relationship between the mutual fund company and related companies- } \\
\text { specifically there are no rules governing the use of a related company for trading services, } \\
\text { borrowing and lending between related companies or the use of a third party custodian. Given } \\
\text { the concentration of the Swedish mutual fund business in bank-owned mutual fund } \\
\text { companies-which may not be separate from the banks themselves-and the use of related } \\
\text { securities firms and custodians, this is an issue which merits attention. It is not clear that the } \\
\text { inspection program has yet addressed the potential conflicts of interest. FI staff rely on the } \\
\text { banks themselves to analyze the conflicts of interest and their approach to them and to report } \\
\text { any problems. Given the incentives at work, this is insufficient. } \\
\text { The FI mutual funds group suffers from both a lack of resources and experience. In this context, } \\
\text { the ability of FI to address these conflicts of interest through inspections is limited. } \\
\text { Owners of mutual funds are not subject to fit and proper assessments-FI does not have the } \\
\text { authority to impose this requirement. }\end{array}$ \\
\hline Principle 18. & $\begin{array}{l}\text { The regulatory system should provide for rules governing the legal form and structure of } \\
\text { collective investment schemes and the segregation and protection of client assets. }\end{array}$ \\
\hline Description & $\begin{array}{l}\text { Under the Mutual Funds Act, a mutual fund must be composed of transferable securities and is } \\
\text { owned by the unit-holders. The mutual fund is not a legal entity and cannot acquire rights or be } \\
\text { obligated to perform duties in a legal sense. The unit-holders of the collective investment } \\
\text { scheme cannot be held liable for duties concerning the fund. } \\
\text { There must be a depository for every collective investment scheme. The depository must be a } \\
\text { bank or a credit institution that holds the assets of the fund and takes care of all the payments to } \\
\text { and from the fund. The depository has an obligation to make sure that the distribution and } \\
\text { valuation of the fund units are done according to the Act and according to the fund rules. They } \\
\text { must also make sure that the assets of the fund are transferred immediately to the depository } \\
\text { and that the assets of the fund are used according to the laws and regulations. The depository } \\
\text { may neither grant nor receive loans or stand surety to the fund. The depository may act for more } \\
\text { than one fund provided assets are appropriately segregated. The depository is not required by } \\
\text { law to report on the fund's compliance with its rules but may do so in practice. } \\
\text { The Act requires FI to revoke a mutual fund license if share capital has been reduced by } 1 / 3 \text { or } \\
\text { if the law has been violated. In the event of an insolvency of a mutual fund, the depository } \\
\text { would take control of the assets of the fund until such time as the assets could be transferred to } \\
\text { another fund company or disbursed to unit holders. }\end{array}$ \\
\hline Assessment & Partly implemented \\
\hline Comments & $\begin{array}{l}\text { As noted under Principle 17, the nature of the concentrated market in Sweden has resulted in } \\
\text { banks owning a large share of the mutual fund business. Simultaneously these banks act as }\end{array}$ \\
\hline
\end{tabular}




\begin{tabular}{|c|c|}
\hline & $\begin{array}{l}\text { custodians or trustees of mutual fund assets. This creates risk to client assets-a third party } \\
\text { independent custodian/trustee would ensure a check on the asset management companies } \\
\text { operations, a second level of protection for customer assets. Complicating this is the fact that } \\
\text { the same banks often operate a securities business through which trades may be made by the } \\
\text { mutual fund company or to which the mutual fund manager might borrow or lend securities. } \\
\text { This also raises risks that abusive behavior would not be caught by a third party or that mutual } \\
\text { fund clients are being disadvantaged by non-arm's length dealings. } \\
\text { Appointed auditors are relied on to carry out checks on compliance with financial reporting and } \\
\text { internal control policies. The use of such auditors is beneficial but should not replace on-site } \\
\text { inspections of mutual fund operations. }\end{array}$ \\
\hline Principle 19. & $\begin{array}{l}\text { Regulation should require disclosure, as set forth under the principles for issuers, which is } \\
\text { necessary to evaluate the suitability of a collective investment scheme for a particular investor } \\
\text { and the value of the investor's interest in the scheme. }\end{array}$ \\
\hline Description & $\begin{array}{l}\text { Non-UCIT mutual funds are subject to the disclosure rules under the Mutual Funds Act. The } \\
\text { Act requires that the fund disclose its 'rules' including investment strategy, asset allocation, } \\
\text { lending policy, the basis upon which it calculates the asset value of the fund and fees and } \\
\text { commission charged on sales and redemptions and trailer fees. These rules may be changed } \\
\text { provided FI specifically permits the change and such change is disclosed with notice to } \\
\text { investors. } \\
\text { Fund companies must provide unit holders with these rules prior to purchase, together with an } \\
\text { information brochure explaining the rules and describing ownership of the fund company. Fund } \\
\text { companies must also make annual and semi-annual reports which are sent to unit holders. } \\
\text { A fund is not required to permit daily redemptions (although most do) but if there are } \\
\text { redemption restrictions these must be included in the prospectus disclosure. Any changes to } \\
\text { redemptions require notification to clients }\end{array}$ \\
\hline Assessment & Partly implemented. \\
\hline Comments & $\begin{array}{l}\text { Swedish mutual funds are subject to prospectus disclosure rules as well as annual and semi- } \\
\text { annual reporting requirements sufficient to provide the investor with information necessary to } \\
\text { evaluate the suitability and value of the fund. }\end{array}$ \\
\hline Principle 20. & $\begin{array}{l}\text { Regulation should ensure that there is a proper and disclosed basis for asset valuation and the } \\
\text { pricing and the redemption of units in a collective investment scheme. }\end{array}$ \\
\hline Description & $\begin{array}{l}\text { In accordance with the Mutual Funds Act, net asset value should be calculated and published at } \\
\text { least once a week. The net-asset-value (NAV) calculation system is approved by FI at the time } \\
\text { of licensing (although this process has recently stopped). FI has not issued any detailed } \\
\text { guidelines concerning this issue but the Mutual Funds Association sets out detailed guidelines } \\
\text { and recommends daily calculation. NAV calculation parameters are described in the fund } \\
\text { company's rules and these are disclosed to clients. } \\
\text { There is no monitoring of NAV calculations - staff inspections do not address NAV } \\
\text { calculations and nor does the auditor. FI plans to examine NAV calculation systems for } 5 \\
\text { companies in } 2002 \text {. } \\
\text { There are no rules governing the valuation of illiquid securities (which can form up to } 10 \\
\text { percent of the portfolio) and thus the FI has limited ability to address the issue even where a } \\
\text { problem is detected. }\end{array}$ \\
\hline Assessment & Partly observed. \\
\hline Comments & $\begin{array}{l}\text { While mutual fund companies are subject to general requirements regarding calculation of asset } \\
\text { value, there is no effective monitoring of compliance with these rules. There are no valuation } \\
\text { standards for illiquid securities. }\end{array}$ \\
\hline Principle 21. & Regulation should provide for minimum entry standards for market intermediaries. \\
\hline
\end{tabular}




\begin{tabular}{|c|c|}
\hline Description & $\begin{array}{l}\text { Sweden has implemented the EU Investment Services Directive (93/22/EEC) through the } \\
\text { Securities Business Act (1991:981), regulations issued by FI (FFFS 1998:21) concerning trade } \\
\text { and services on the securities market and general guidelines issued by FI (FFFS 1998:34) } \\
\text { concerning what a licensing application should contain. } \\
\text { There is one category of license-that of investment firm-which applies to all market } \\
\text { intermediaries, including banks, carrying on a securities business. An investment firm is } \\
\text { required to have a minimum capital (set on a scale correspondent to the type of business being } \\
\text { undertaken), an appropriate business plan and articles of association, an appointed auditor and a } \\
\text { Board of Directors of at least } 5 \text { persons. The firm must demonstrate an adequate complaint } \\
\text { handling process and must appoint a compliance officer. } \\
\text { The applicant must specify which of the five types of business listed under s.3 of the Act it } \\
\text { intends to carry out-it can be a combination-and this forms the basis of its license and } \\
\text { licensing requirements. Any changes to the terms upon which the license was granted must be } \\
\text { reported to FI, which has the right to object to the change. } \\
\text { Directors and officers of the investment firm are subject to fit and proper testing including a } \\
\text { police check. There are no proficiency requirements for directors, officers or employees. } \\
\text { Employees themselves are not registered with FI and are not required to be separately licensed. } \\
\text { FI is currently considering rules that would establish personnel competence requirements. The } \\
\text { SSDA has recently launched a licensing program for individual employees which is voluntary } \\
\text { and applies only to SSDA members. } \\
\text { An applicant must be simultaneously accepted as a member of the Deposit Guarantee Board in } \\
\text { order to receive a license. There are a large number of investment firms that do not handle cash } \\
\text { or securities- rather they carry out a sales business and rely on a larger investment firm to } \\
\text { process and execute transactions for clients, keep custody of client assets, fund customer } \\
\text { accounts and so on. These investment firms are not required to belong to the Deposit Guarantee } \\
\text { Fund but are subject to capital requirements and must carry indemnity insurance. }\end{array}$ \\
\hline Assessment & Implemented \\
\hline Comments & $\begin{array}{l}\text { The entry standards for investment firms are sufficient to establish a meaningful standard of } \\
\text { licensing. }\end{array}$ \\
\hline Principle 22. & $\begin{array}{l}\text { There should be initial and ongoing capital and other prudential requirements for market } \\
\text { intermediaries that reflect the risks that the intermediaries undertake. }\end{array}$ \\
\hline Description & $\begin{array}{l}\text { Capital requirements are set out in Chapter } 2 \text { of the Securities Operations Act and are in } \\
\text { compliance with the EU Directive on Capital Adequacy (93:6, EEC). There are both minimum } \\
\text { and on-going requirements. Minimum standards are set according to the activity undertaken. } \\
\text { On-going capital adequacy is determined by a formula as set out in the Capital Adequacy and } \\
\text { Large Exposure Act. Each licensed investment firm must report its financial position on a } \\
\text { quarterly basis, along with large exposure reporting every } 6 \text { months. Extensive reporting and } \\
\text { audited financial statements are required annually. Cross-guarantees between related companies } \\
\text { are not required. } \\
\text { In the event a licensee fails to meet the minimum requirements in the quarterly filing, FI will } \\
\text { give the licensee notice that it must correct this deficiency. }\end{array}$ \\
\hline Assessment & Partly implemented \\
\hline Comments & $\begin{array}{l}\text { Capital adequacy levels are compliant with international and European standards. A more } \\
\text { frequent filing of financial reports might be considered-the value of financial reporting is as } \\
\text { an early warning of financial difficulties which might endanger customer assets. Financial } \\
\text { insolvencies are often the result of fraud rather than financial mismanagement or low revenues } \\
\text { and early detection can prevent serious customer losses. As discussed throughout the } \\
\text { assessment, FI has a limited authority to take action against a regulated entity. Deficiencies in }\end{array}$ \\
\hline
\end{tabular}




\begin{tabular}{|c|c|}
\hline & $\begin{array}{l}\text { capital levels should be addressed with a more effective and flexible tool than a three-month } \\
\text { warning-the warning period is very long leaving a large gap in which the financial position } \\
\text { could worsen. This risk is tempered considerably by FI's right to demand immediate } \\
\text { rectification if a firm falls below its on-going capital adequacy calculation requirement. FI can, } \\
\text { in that case, also require more frequent reporting and prevent the securities business from taking } \\
\text { on activities until the deficiency is met. }\end{array}$ \\
\hline Principle 23. & $\begin{array}{l}\text { Market intermediaries should be required to comply with standards for internal organization } \\
\text { and operational conduct that aim to protect the interests of clients, ensure proper management } \\
\text { of risk, and under which management of the intermediary accepts primary responsibility for } \\
\text { these matters. }\end{array}$ \\
\hline Description & 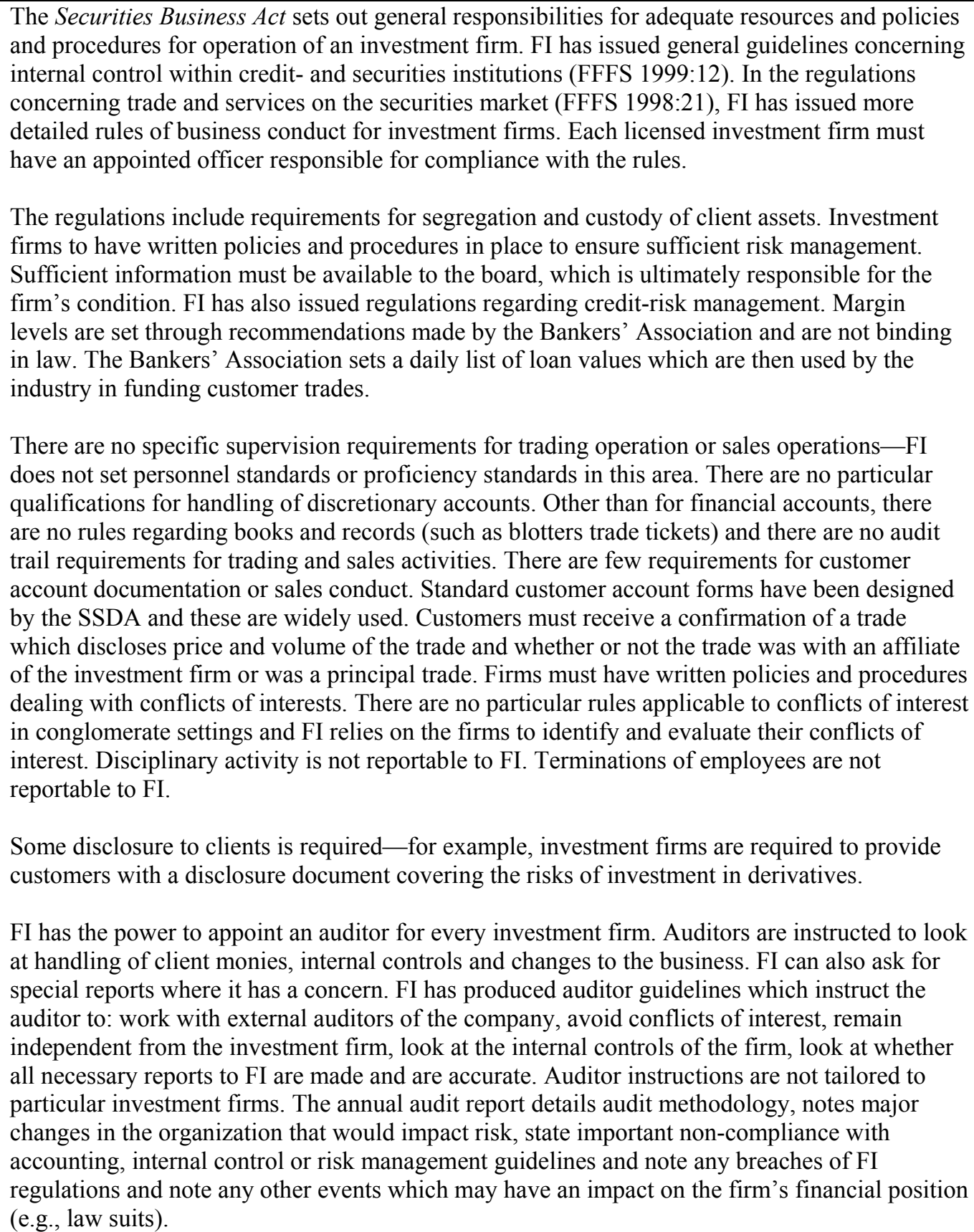 \\
\hline
\end{tabular}




\begin{tabular}{|c|c|}
\hline & $\begin{array}{l}\text { FI has the authority to compel production of documents, enter premises and carry out any sort } \\
\text { of inspection. FI has carried out themed inspections including off-site reporting requirements } \\
\text { (production of trading instructions, complaint handling procedures etc.) and on-site inspections. } \\
\text { Inspections are discussed under Principle } 10 \text {. } \\
\text { Investment firms registered as credit institutions can take deposits from customers-provided } \\
\text { the customer has opened an account for this purpose. These deposits form part of the firm's } \\
\text { working capital and do not have to be segregated. If it wishes to engage in this business, the } \\
\text { firm must be a contributor to the Deposit Guarantee Fund, which protects client deposits in case } \\
\text { of a failure, and must comply with higher capital levels applicable to credit institutions. Most of } \\
\text { the large stock exchange members fall into this category. } \\
\text { Firms that do business in Sweden must either be licensed by FI or by an EU jurisdiction. } \\
\text { European investment firms that comply with the Directive can operate in Sweden. If the branch } \\
\text { in Sweden is an affiliate of an investment firm in the EU, it is regulated by its country. The } \\
\text { branch in Sweden must become a member of the Deposit Guarantee Board. }\end{array}$ \\
\hline Assessment & Partially implemented. \\
\hline Comments & $\begin{array}{l}\text { The law has gaps in investor protection rules including disclosure to clients, documentation of } \\
\text { accounts. Customers with margin accounts, for example, do not received special disclosure. } \\
\text { Disclosure of fees or commissions is not required. There are no books and records requirements } \\
\text { and audit trail requirements for sales and trading that would ensure that customer transactions } \\
\text { are properly recorded and reconciled. There are no qualification or supervision requirements for } \\
\text { portfolio managers or those with discretionary trading rights over customer accounts. These } \\
\text { issues are apparently being dealt with in proposals from CESR - these should be supported and } \\
\text { implemented. } \\
\text { The inspection program relies very heavily on the appointment of auditors and these auditors in } \\
\text { turn focus on financial reporting and internal control systems. There are no audits of customer } \\
\text { accounts, no audits of conflicts of interest management and no trade desk reviews. There is little } \\
\text { focus on sales conduct in the system. Issues which may arise at the customer account level such } \\
\text { as fraud, manipulation, misrepresentation are thus not captured by the inspection system. } \\
\text { Further, the heavy use of auditors means that FI is not developing skills or understanding of the } \\
\text { industry's practices. } \\
\text { In following up on inspection findings, FI is hampered by a lack of flexibility in its approach to } \\
\text { enforcing compliance, its limited authority over individual employees and its limited authority } \\
\text { to impose penalties. It appears that moral suasion is the chief tool used to remedy deficiency } \\
\text { findings which may not always be sufficient. }\end{array}$ \\
\hline Principle 24. & $\begin{array}{l}\text { There should be a procedure for dealing with the failure of a market intermediary in order to } \\
\text { minimize damage and loss to investors and to contain systemic risk. }\end{array}$ \\
\hline Description & $\begin{array}{l}\text { Market intermediaries are subject to rules regarding their delicensing and winding-up. FI } \\
\text { monitors the financial conditions of market intermediaries and if capital levels fall below those } \\
\text { required by the capital adequacy calculation (according to the quarterly filings) the FI will } \\
\text { require the investment firm to bring the capital level to compliant and may require frequent } \\
\text { financial reporting until the situation is stable. If it is not corrected the investment firm must be } \\
\text { wound-down. FI has no ability to impose restrictions on the investment firm's conduct of } \\
\text { business during this time although it have the authority to require infusions of capital. Transfers } \\
\text { of investor assets to a new buyer have to be approved with disclosure notice and approval of } \\
\text { investors. } \\
\text { The Investor Guarantee Fund, administered by the Deposit Guarantee Board, is in place to } \\
\text { protect investor assets of up to SKR } 250,000 \text { per customer in the case of insolvency. The Fund }\end{array}$ \\
\hline
\end{tabular}




\begin{tabular}{|c|c|}
\hline & $\begin{array}{l}\text { does not currently have reserves in place but would have the ability to collect contributions } \\
\text { from regulated market intermediaries covered by the Fund in the event that funds were required. } \\
\text { This has never occurred. The Fund does not have an ability to act on behalf of investors or to } \\
\text { step in to administer the estate of the failed brokerage firm-the Fund must wait until legal } \\
\text { proceedings have concluded and the market intermediary has been declared bankrupt before } \\
\text { payment can be made. }\end{array}$ \\
\hline Assessment & Partially implemented. \\
\hline Comments & $\begin{array}{l}\text { FI has the legal ability to manage the wind-up of an investment firm-in practice, however, } \\
\text { there may be some limitations on FI's ability to handle a failure. FI has the ability to prevent the } \\
\text { investment firm from undertaking certain risks (for example, bought deal underwriting or } \\
\text { expansion of business) until capital levels are met. The Investor Guarantee Fund provides } \\
\text { investors with protection but the bankruptcy process may be long and there is the potential for } \\
\text { market disruption in the meantime as investor assets may be frozen for a period of time. FI has } \\
\text { avoided this difficulty so far by working with troubled firms to arrange transfer of accounts or } \\
\text { take-over of the business, ensuring a smooth transition for investors. While there is no } \\
\text { requirement under this Principle to have ability to appoint a receiver to take up administration } \\
\text { of the estate, FI may wish to consider such authority-this would avoid disruption in the event } \\
\text { of the failure of a large market intermediary for whom a buy-out could not easily be arranged. }\end{array}$ \\
\hline Principle 25. & $\begin{array}{l}\text { The establishment of trading systems including securities exchanges should be subject to } \\
\text { regulatory authorization and oversight. }\end{array}$ \\
\hline Description & $\begin{array}{l}\text { The Securities Exchange and Clearing Operations Act contemplates the operation of both } \\
\text { exchanges and authorized marketplaces. A trading system that organizes trading among a wide } \\
\text { group of participants on a continuous basis must be licensed. The license may be as an } \\
\text { exchange or an authorized marketplace, or as an investment firm under the Securities Business } \\
\text { Act. Authorized marketplaces are trading systems without members and with no disciplinary } \\
\text { function but which carry out listing and surveillance functions. There are two authorized } \\
\text { marketplaces currently operating, offering trading in small companies which do not have } \\
\text { listings on Stockholmbörsen. In order to obtain a license as an authorized marketplace, an } \\
\text { application must be made to FI, and FI must be satisfied that the market surveillance system is } \\
\text { adequate, the system has adequate technical capacity and an audit trail is maintained, there must } \\
\text { be skilled management and the system must have adequate financial resources. The licensing } \\
\text { process is set out in FI regulations. } \\
\text { Stockholmbörsen has been licensed under the Act since } 1999 \text { at the time of the merger of the } \\
\text { options and stock exchange. } \\
\text { There are very detailed rules regarding the market surveillance system required by all trading } \\
\text { systems -the rules outline necessary skills, capacity and technical systems. }\end{array}$ \\
\hline Assessment & Implemented. \\
\hline Comments & $\begin{array}{l}\text { Licensing requirements for trading systems - including both exchanges and alternative trading } \\
\text { systems - are clearly set out in legislation and guidelines. The trading systems are subject to } \\
\text { oversight and supervision. }\end{array}$ \\
\hline Principle 26. & $\begin{array}{l}\text { There should be ongoing regulatory supervision of exchanges and trading systems, which } \\
\text { should aim to ensure that the integrity of trading is maintained through fair and equitable rules } \\
\text { that strike an appropriate balance between the demands of different market participants. }\end{array}$ \\
\hline Description & $\begin{array}{l}\text { FI is responsible for supervision of authorized marketplaces and exchanges under the Securities } \\
\text { Exchange and Clearing Operations Act. Entities must report any proposed changes to the } \\
\text { conditions of its license-and FI has the right to object to the change. For example, the merger } \\
\text { of the derivatives and stock exchanges in } 1999 \text { was a major change to the conditions under } \\
\text { which these entities had been granted a license and therefore had to be reported to FI, who had } \\
\text { the right to object. FI does not have the authority to impose a positive act on its exchanges or } \\
\text { authorized marketplaces. }\end{array}$ \\
\hline
\end{tabular}




\begin{tabular}{|c|c|}
\hline & $\begin{array}{l}\text { FI establishes an annual supervision plan for Stockholmbörsen. Supervision of the exchange } \\
\text { and authorized marketplaces includes monthly meeting with each at which a standing agenda is } \\
\text { discussed and information is shared. FI has the right to inspect exchanges and authorized } \\
\text { marketplaces. It also requires each trading system to have an auditor which FI can instruct } \\
\text { (similar to its process for market intermediaries). Should a concern arise, FI can instruct the } \\
\text { auditor (at the trading system's expense) to report. Stockholmbörsen files capacity reports with } \\
\text { FI and these are discussed at monthly meetings. Halts, opening and closing of the market, } \\
\text { disciplinary issues and disruptions in trading are also discussed. Stockholmbörsen must file all } \\
\text { rules with FI which as the power to object to the rules. FI does not have the power to impose a } \\
\text { rule on Stockholmbörsen but can pass its own legislation. } \\
\text { Stockholmbörsen must file an annual report with audited financial statements annually and an } \\
\text { unaudited set of statements semi-annually. The law requires the exchange to have sufficient } \\
\text { capital but the exchange is not subject to a specific capital requirement. Currently } \\
\text { Stockholmbörsen has a self-imposed capital level. Stockholmbörsen carries insurance to cover } \\
\text { its counterparty risk exposure as the central counterparty in derivatives clearing. There is no } \\
\text { requirement to report specifically on its capital position or risk management. } \\
\text { FI can prohibit Stockholmbörsen from taken certain actions but cannot impose a positive } \\
\text { obligation on the exchange. In practice, FI believes it has a very good working relationship with } \\
\text { the exchange. } \\
\text { The requirements for authorized market places and VPC, the clearing and settlement system for } \\
\text { debt and equities, are the same. }\end{array}$ \\
\hline Assessment & Partly implemented. \\
\hline Comments & $\begin{array}{l}\text { As discussed under Principle } 7 \text {, there is a need for increased on-site inspections by FI staff. The } \\
\text { central importance of the Stockholmbörsen and the VPC to the capital markets require } \\
\text { increased vigilance regarding their operation-particularly since these are both for-profit } \\
\text { private companies. }\end{array}$ \\
\hline Principle 27. & Regulation should promote transparency of trading. \\
\hline Description & $\begin{array}{l}\text { The Securities Exchange and Clearing Operations Act stipulates that an exchange shall provide } \\
\text { adequate transparency of trading-exchange members shall receive prompt, simultaneous and } \\
\text { correct information regarding trading and the information is also available to the general public. } \\
\text { Equity trading on Stockholmbörsen is done on a fully automated auction market-pre-trade } \\
\text { orders are displayed and there is immediate post-trade reporting at execution of the trade. } \\
\text { Trades can be executed off-exchange-small orders of } 20 \text { boards lots or less must be exposed to } \\
\text { the market, orders of } 20-250 \text { board lots can be executed off exchange but between the bid and } \\
\text { ask spread and orders of } 250 \text { board lots or more can be executed off-exchange at any price. } \\
\text { After-hours trades are reported prior to market open on the following day. } \\
\text { There is no pre-trade transparency of orders required on the fixed income market but executed } \\
\text { trades must be reported daily. The Fixed Income Market provides transparency of bid and ask } \\
\text { prices but is voluntary. The over-the-counter equity market is not subject to transparency } \\
\text { requirements. Se market intermediaries offer transparency of prices or post bids and offers for } \\
\text { these securities but on a voluntary basis. } \\
\text { There is no best execution requirement for customer trades-there is the requirement to denote } \\
\text { a principal on the trade confirmation. }\end{array}$ \\
\hline Assessment & Implemented. \\
\hline Comments & $\begin{array}{l}\text { There is a general requirement for transparency of trading in Sweden. Transparency in the fixed } \\
\text { income and OTC equity market is more limited than on the listed equity market- - however } \\
\text { these transparency standards are in line with those in most countries. }\end{array}$ \\
\hline
\end{tabular}




\begin{tabular}{|c|c|}
\hline Principle 28. & $\begin{array}{l}\text { Regulation should be designed to detect and deter manipulation and other unfair trading } \\
\text { practices. }\end{array}$ \\
\hline Description & $\begin{array}{l}\text { Insider reporting covered by the Act concerning Reporting Obligations for Certain Holdings of } \\
\text { Financial Instruments Act (2000:1087). Insiders are defined as owners of } 10 \text { percent or more of } \\
\text { shares, auditors, management, and directors. Insiders must report all trades within } 5 \text { days. The } \\
\text { company is responsible for providing a complete list of insiders and must notify FI of changes } \\
\text { to the list within five days. Lists of insider trades are published on the FI internal website- the } \\
\text { public has access to the information if they contact FI. Insider trading is prohibited by the } \\
\text { Insider Penalties Act (2000:1086). } \\
\text { Employees of licensed market intermediaries are required to report all trades to the firm and must } \\
\text { hold all investments for three months (with se exceptions). There are no rules regarding } \\
\text { restrictions on trading during a distribution where the investment firm is the underwriter. There } \\
\text { are no rules regarding disclosure to clients of the firm's ownership in securities being sold or of } \\
\text { the firm's affiliate status. Front running is not included in Swedish rules. Many of these rules are } \\
\text { being contemplated for EU implementation by CESR. The SSDA also sets rules regarding market } \\
\text { conduct but does not have the authority to enforce or monitor compliance with these rules. } \\
\text { The Stockholmbörsen has a sophisticated market surveillance system designed to detect } \\
\text { manipulative trading. The authorized exchanges are required to have market surveillance systems } \\
\text { and investment firms must have policies and procedures in place to monitoring trading activity. }\end{array}$ \\
\hline Assessment & Implemented \\
\hline Comments & $\begin{array}{l}\text { Market abuse rules are in place, although there are few rules governing corporate finance } \\
\text { activities or supervision of trading. The proposed EU Directive on market abuse will expand the } \\
\text { scope of trading rules and may require FI and Stockholmbörsen to expand their investigation } \\
\text { and enforcement activities. }\end{array}$ \\
\hline Principle 29. & $\begin{array}{l}\text { Regulation should aim to ensure the proper management of large exposures, default risk and } \\
\text { market disruption. }\end{array}$ \\
\hline Description & $\begin{array}{l}\text { Default risk is minimized through capital adequacy requirements for investment firms and } \\
\text { through risk management and clearing and settlement systems. The licensing system requires } \\
\text { minimum standards for investment firms including minimum capital. On-going capital } \\
\text { adequacy requirements are also applied to market intermediaries and these are monitored } \\
\text { through quarterly reporting to FI. Annual audits of capital adequacy are undertaken by the } \\
\text { investment firm auditor appointed by FI. The capital adequacy calculations taken into account } \\
\text { counterparty exposure, exposure limits for issuers or products, credit risk, liquidity risk and } \\
\text { market risk. Risk management practices are required at all firms. } \\
\text { VPC is the only clearing and settlement system for equity and fixed income trading currently } \\
\text { operating in Sweden. VPC has a direct relationship with settlement banks, clearing members } \\
\text { (registered investment firms), customers with accounts open in its registry (3 million plus) and } \\
\text { issuers. Besides carrying out clearing and settling of equity and debt trades, VPC also acts as } \\
\text { agent for the distribution of dividends and rights and as the agent for issuers in disseminating } \\
\text { shareholder mailings. } \\
\text { Stockholmbörsen operates a derivatives clearing system which clears derivatives trades on the } \\
\text { Stockholmbörsen, and the Oslo Børs, the Copenhagen and London exchanges. The } \\
\text { Stockholmbörsen system also handles clearing in custom-made OTC derivatives-a very large } \\
\text { segment of the derivatives market. } \\
\text { Settlement default in equity trading is managed by VPC's risk management system. The system } \\
\text { has established a guarantee fund to handle defaults in equity trades. Settlement risks for fixed } \\
\text { income trades are also netted but there is no guarantee fund and no collateralization of the risk. } \\
\text { This issue is discussed in detail in the securities settlement system Section. }\end{array}$ \\
\hline
\end{tabular}




\begin{tabular}{|c|c|}
\hline & $\begin{array}{l}\text { Position-limits are developed and monitored by the derivatives clearing operation at } \\
\text { Stockholmbörsen and members of the exchange are required to post collateral in accordance } \\
\text { with Stockholmbörsen rules. Stockholmbörsen monitors both the member's exposure and the } \\
\text { individual clients exposure. Stockholmbörsen has created a central counterparty for derivatives } \\
\text { clearing as a means of mitigating settlement risk. The central counterparty is supported by } \\
\text { capital and insurance. }\end{array}$ \\
\hline Assessment & Partially implemented. \\
\hline Comments & $\begin{array}{l}\text { In general the system protects against settlement defaults and market disruption. The VPC } \\
\text { system has an unchecked settlement risk in fixed income security settlements as noted. The } \\
\text { systemic importance of clearing and settlement requires sufficient attention to these issues. A } \\
\text { major settlement default on the derivatives, fixed income or equity markets could cause the } \\
\text { failure of an investment firm or settlement bank which would at a minimum disrupt the market } \\
\text { and at the most cause other defaults and huge losses for the market. }\end{array}$ \\
\hline Principle 30. & $\begin{array}{l}\text { Systems for clearing and settlement of securities transactions should be subject to regulatory } \\
\text { oversight, and designed to ensure that they are fair, effective and efficient and that they reduce } \\
\text { systemic risk. }\end{array}$ \\
\hline Description & $\begin{array}{l}\text { Under the Securities Exchange and Clearing Operations Act, clearing and settlement systems } \\
\text { and central depositories must be licensed and supervised by FI. The clearing operation or } \\
\text { depository must demonstrate skill and capacity to undertake clearing and/or custody operations. } \\
\text { Officers and directors are subject to fit and proper testing. } \\
\text { FI has the authority to appoint auditors and carry out inspections. FI appointed auditors have, in } \\
\text { the past, audited the financial conditions of VPC and Stockholmbörsen as well as internal } \\
\text { control systems and technology. FI has the right to object to rule changes proposed by VPC or } \\
\text { Stockholmbörsen. FI staff meet monthly with both organizations to discuss a standing agenda } \\
\text { of items which can include risk management, operational issues and proposed systems changes. } \\
\text { Clearing and settlement is dealt with in detail in the securities settlement system Section of this } \\
\text { report. }\end{array}$ \\
\hline Assessment & Partially implemented. \\
\hline Comments & $\begin{array}{l}\text { FI does not review risk management or stress testing reports nor does it set reporting } \\
\text { requirements for Stockholmbörsen or VPC. FI has not reviewed or approved the risk } \\
\text { management models employed by the systems. FI has kept its supervision relatively informal } \\
\text { using monthly staff meetings to discuss issues. It is not clear that FI has developed sufficient } \\
\text { supervisory skills to enable it to fully understand and address the VPC or Stockholmbörsen } \\
\text { clearing and settlement systems. FI is currently reviewing its supervision system for both } \\
\text { systems. }\end{array}$ \\
\hline
\end{tabular}

Table 8. Summary Implementation of the IOSCO Objectives and Principles of Securities Regulation

\begin{tabular}{l|l|l}
\hline \multicolumn{1}{c}{ Assessment } & \multicolumn{2}{c}{ Principles Grouped by Assessment Grade } \\
\cline { 2 - 3 } \multicolumn{1}{c}{ Grade } & Count & \multicolumn{1}{c}{ List } \\
\hline Implemented & 14 & $1,2,4,5,8,11,12,13,16,19,21,25,27 \& 28$ \\
Partially & 16 & $3,6,7,9,10,14,15,17,18,20,22,23,24,26,29 \& 30$ \\
Implemented & & \\
Not Implemented & & \\
Not applicable & & \\
\hline
\end{tabular}




\section{G. Recommended Actions and Authorities' Response to the Assessment}

\section{Recommended Actions}

Table 9. Recommended Plan of Actions to Improve Observance of the IOSCO Objectives and Principles of Securities Regulation

\begin{tabular}{|c|c|}
\hline Reference Principle & Recommended Action \\
\hline Principle 3 & $\begin{array}{l}\text { FI should be granted authority over third parties. } \\
\text { Legislation or licensing requirements should be amended } \\
\text { to enable FI to take interim or corrective measures. }\end{array}$ \\
\hline Principle 6 & $\begin{array}{l}\text { FI should consider its relationship to the informal SROs } \\
\text { and take steps to balance its own activities and supervision } \\
\text { of market intermediary and listed company regulation } \\
\text { should that it has a presence in these areas. }\end{array}$ \\
\hline Principle 7 & $\begin{array}{l}\text { The current intention to strengthen supervision of } \\
\text { Stockholmbörsen and VPC should be vigorously pursued. }\end{array}$ \\
\hline Principle 8 & $\begin{array}{l}\text { FI should be granted authority to compel evidence from } \\
\text { third parties. }\end{array}$ \\
\hline Principle 9 & $\begin{array}{l}\text { FI should be granted authority to carry out full enforcement } \\
\text { proceedings and levy fines and penalties. }\end{array}$ \\
\hline Principle 10 & $\begin{array}{l}\text { FI should increase resources devoted to inspections of } \\
\text { investment firms, mutual fund companies and SROs. }\end{array}$ \\
\hline Principle 11 & $\begin{array}{l}\text { FI should strengthen the supervision the regulation of listed } \\
\text { companies by Stockholmbörsen. } \\
\text { Prospectus review at FI should be strengthened. } \\
\text { Continuous disclosure standards should be applied to } \\
\text { unlisted issuers. }\end{array}$ \\
\hline Principle 12 & $\begin{array}{l}\text { FI should enhance its activity in this area of regulation- } \\
\text { minority shareholder rights could be strengthened and } \\
\text { should also apply to unlisted issuers. }\end{array}$ \\
\hline Principle $17 \& 18$ & $\begin{array}{l}\text { Adequate controls on conflicts of interest in dealings } \\
\text { between related companies should be addressed through } \\
\text { stronger requirements and on-site inspections. } \\
\text { Owners of mutual fund companies should be subject to fit } \\
\text { and proper testing. }\end{array}$ \\
\hline Principle 20 & $\begin{array}{l}\text { A system for monitoring net asset valuation requirements } \\
\text { should be established. } \\
\text { Rules for valuation of illiquid securities should be } \\
\text { developed. }\end{array}$ \\
\hline Principle 22 & $\begin{array}{l}\text { More frequent reporting of capital positions should be } \\
\text { considered. }\end{array}$ \\
\hline
\end{tabular}




\begin{tabular}{|l|l|}
\hline Principle 23 & $\begin{array}{l}\text { FI will be required by proposed EU Directives to introduce } \\
\text { more detailed rules for investment firms. This should be } \\
\text { supported. }\end{array}$ \\
\hline Principle 24 & $\begin{array}{l}\text { Greater resources should be devoted to the inspection } \\
\text { program. }\end{array}$ \\
\hline Principle 29\&30 & $\begin{array}{l}\text { F should consider its practical ability to handle a large } \\
\text { failure consideration of the ability to act as administrator } \\
\text { of an insolvent firm prior to bankruptcy proceedings so that } \\
\text { client accounts may be transferred, preventing market } \\
\text { disruption. }\end{array}$ \\
\hline $\begin{array}{l}\text { As noted in the securities settlement system portion of this } \\
\text { report, it is strongly recommended that oversight of VPC } \\
\text { and Stockholmbörsen clearing systems be strengthened. } \\
\text { The current shortcomings of the VPC risk management } \\
\text { system should be addressed. }\end{array}$ \\
\hline
\end{tabular}

\section{H. Authorities' Response}

79. The authorities were in broad agreement with the assessment-pointing out that many of the issues including enhanced standards for issuers and investment firms will be implemented as a result on on-going work at the EU. The current FI business plan also contemplates increased attention to both VPC and Stockholmborsen and the authorities believe that once the new plan is fully operational oversight concerns will be satisfactorily addressed. The VPC is adopting a two-step approach to address the risks in the VPC, which will fully eliminate the present "unwinding" procedure and has adopted a plan to eliminate indirect participation.

\section{The CPSS CORE PRINCIPLES}

\section{A. General}

80. The assessment of observance of the CPSS Core Principles for Systemically Important Payment Systems of the RIX-System and the responsibilities of the Riksbank in applying the Core Principle in Sweden was performed by Mr. Jan Woltjer of the Nederlandsche Bank. The main sources for this assessment were:

(a) the Blue book, payments and securities settlement systems in the European Union, published by the European Central Bank and The Swedish Financial Market, an annual review published by the Riksbank;

(b) the settlement of payments in the RIX-system, a publication of the Riksbank, in which a description of its role in the Swedish payment system and the functioning of the RIX-system is given, also available on the website of the Riksbank; 
(c) publications on the Riksbank's oversight of the financial infrastructure published in the Financial Market Report 1997-I and in the Sveriges Riksbank Economic Review 2001-3;

(d) the Sveriges Riksbank act and other relevant laws with respect to banking activities, financial markets and the clearing, settlement and custody of securities in Sweden, all available on the website of different institutions in Sweden;

(e) Rules and Regulations for settlement of payment in RIX, publicly available;

(f) a decision of the executive board of the Riksbank with respect to collateral requirements and Information on eligibility requirements for collateral in RIX published by the Riksbank and available on the website; and

(g) a confidential risk analysis performed by the Riksbank using the TARGET risk analysis methodology of the European System of Central Banks.

81. Several meetings were held with:

(a) Different officials of the Riksbank charged with operational tasks, monetary policy or with the oversight of the financial infrastructure.

(b) FI, the financial supervisory authority charged with the supervision of the financial sector in Sweden including clearing houses for payments and securities.

(c) The Banking Association

(d) The Bankgirocentralen

(e) VPC

(f) The Stockholmbörsen

(g) Representatives of the banking sector. In the meetings with the Riksbank additional information was received about the relationship between intraday liquidity and overnight liquidity provided in the framework of monetary policy, the operability of the RIX-system, the crisis management organization in the Riksbank in case of severe disturbance or a failure in the financial sector, the provision of emergency liquidity (ELA) and the prevention of financial crisis in the Swedish system by means of oversight.

82. The assessment was performed on the basis of the methodology published in the CPSS-report on Core Principles for Systemically Important Payment Systems and the guidance note of assessing observance with these principles and the structure and scope of the assessment report prepared by the IMF and the World Bank. Prior to the mission, the 
Riksbank submitted a self-assessment of the Core Principles with respect to the RIX-system and the responsibilities of the Riksbank in applying the core principles. The Bankgirocentralen also submitted a self-assessment on the functioning of the Bankgirotsystem. Further on, in the framework of the FSAP-mission to Sweden, an assessment was made by the same assessor, with the assistance of Ms. Jennifer Elliott of the IMF, of observance of VPC with the CPSS/IOSCO recommendation on Securities Settlement Systems and the functioning of the clearing and settlement system for derivatives of Stockholmbörsen. During the mission the Riksbank and Finansinspectionen provided a selfassessment of observance of VPC with the CPSS/IOSCO recommendations. On request, the Financial Supervisory authority also produced a self-assessment of the clearing and settlement of derivatives by Stockholmbörsen based on the oversight framework used in the Netherlands to oversee the clearing and settlement systems of Euronext Amsterdam.

83. The assessor did not encounter any major barriers in making his assessment.

\section{B. Institutional and Market Structure}

84. The major players/systems in the Swedish payment system are:

- $\quad$ Sveriges Riksbank. The Riksbank owns and operates the interbank settlement system RIX. The system operates on an RTGS basis and is primarily designed for large-value payments. RIX consists of two parallel but separate systems; K-RIX for settlement in Swedish kronor and E-RIX for settlement in euro. E-RIX is inter-linked to the ECB's TARGET system.

- $\quad V P C$. VPC is a clearing and settlement organization. It operates two securities settlement systems, one for equities and one for fixed income paper, and provides services as a central securities depository. Equities, bonds and money market instruments are all dematerialized in the VPC system. Cash settlement is made in central bank money via Riksbank accounts in the RIX system. Settlement is made on a multilateral net basis or on an RTGS basis. The latter is manually operated. In both processes, the cash settlement takes place at the same time as the settlement of securities. Delivery-versus-payment is thus achieved.

- $\quad$ Stockholmbörsen. The Stockholm Exchange clears and settles derivatives and acts as a central counterpart in the transactions that are cleared and settled. The clearing activity covers both derivative products traded on the Stockholm Exchange and products traded outside the exchange (OTC). All funds settlements are made via the Stockholm Exchange account in the RIX system on a multilateral net basis.

- $\quad$ Bankgirocentralen (BGC). BGC manages and develops the Bankgirot system and offers its products and services to the banks. Retail payments, such as credit transfers, direct debits and card payments, but also certain large-value payments are processed. BGC recently adopted a new technical platform and new clearing and settlement procedures, which has led to the full integration of the RIX system, BGC's clearing 
information system and the clearing participants internal systems. The payments are settled on a bilateral net basis in the RIX system at a number of times per day.

- $\quad$ Postgirot. Postgirot is essentially a system for credit transfers between accounts held within the Postgirot Bank. The Postgirot system processes retail payments to and from companies and households and government's payments. Settlement is made in commercial bank money. Postgirot Bank has recently become a full member of the Bankgirot system, which has led to interoperability between the two systems.

- Riksgäldskontoret. Riksgäldskontore, the Swedish National Debt Office, participates in the RIX system as the government agency responsible for the management and processing of government payments.

85. Payment and securities settlement systems are overseen by Riksbank as well as by FI. The Riksbank is charged in the Sveriges Riksbank Act with promoting a safe and efficient payment system and, within that framework, is responsible for the oversight of the financial infrastructure. FI is charged with supervision of Bankgirot system, VPC and Stockholmbörsen. The oversight of the Riksbank concerns the stability of a system or a market as a whole, while supervision of Finansinspectionen concerns the stability of each individual system provider.

86. The RIX-system is a large value payment system in which, apart from the Riksbank and the aforementioned clearing systems for retail payments and securities, sixteen banks participate. Seven participants are branches of foreign banks. Remote access, participation without a physical representation in Sweden, is possible, but for the time being does not occur. In the RIX-system annually nearly 575 thousand payments are cleared and settled with a nominal value of SKR 122 trillion (\$14 704 billion). Part of this turnover relates to payments in Euro (in 2000: 62000 payments with a value of 1718 billion of euro). Interbank transfers form the bulk of the payments next to large customer transactions.

Approximately 85 percent of the transaction in kronor and almost all transaction in euro are stemming from the four largest financial groups in Sweden. The value of transaction in the BGC forms only 4 percent of the value cleared and settled in the RIX-system but surpass in numbers of transaction the RIX-system by large with an amount of 424 million transactions in 1999. In the same year VPC clears and settles 431 thousand transactions in government securities and 8.4 million transactions in equities. Transactions in bonds and money market paper are for a large amount wholesale transaction (the value cleared amounted up to SKR 84 trillion in 1999) while in the equity market retail transactions dominated (total value annually cleared SKR 4 trillion).

87. The bulk of non-cash payment transactions by companies and households are made through the two giro systems; Bankgirot and Postgirot. In 1999 these two systems for credit transfers together accounted for more than 75 percent of all non-cash transactions. A growing proportion of the transactions in the giro systems are initiated electronically, around 80 percent in terms of value in 1999. The number of cheques has decreased substantially in recent years and direct debits, called autogiro in Sweden, still account for a rather limited share (around 8 percent) of the total number of non-cash transactions, although the 
importance is growing. The use of cards has increased gradually over time. While credit cards never has played a significant role in Sweden, debit cards have gained in importance and most notably those debit cards linked to bank accounts. Regarding prepaid cards, there is one card-based scheme in operation, the Cash card. The Cash card is issued by the four major Swedish banks. Acceptance among customers has been rather low up to now.

88. Factors that have had an impact on the Swedish payment system are:

- The rapid growth in the financial markets during recent years. It has increased the number of transactions and, especially, the total value of transactions settled in the Riksbank's settlement system.

- $\quad$ The highly concentrated banking sector in Sweden. The major banking groups (FöreningsSparbanken, Handelsbanken, Nordbanken and SEB) are the major counterparts in the RIX system and for monetary policy operations and the majority owners of BGC and VPC. Progressive integration influence the amount and value of interbank payments and strengthens the influence of the Four Major Financial Groups (FMFG) as well in the financial markets as in the payment industry.

- The rapid growth of internet penetration. More than half of the Swedish population has access to internet at home and about 50 percent of them have access to their bank's internet services.

89. Major payment system reforms in Sweden:

- In 1990, the Riksbank implemented the RTGS system RIX. Earlier, the Riksbank used a system with both deferred net settlement functions and RTGS functions.

- In 1997-98, the Riksbank implemented the SWIFT-service SWIFT FinCopy. This service made straight-though-processing (STP) possible.

- In 1999, the Riksbank implemented E-RIX, which is interlinked to the ECB's TARGET system.

- $\quad$ BGC has adopted a new technical platform and new clearing and settlement procedures, which have led to full integration of the RIX system, BGC's clearing information system and clearing participants' in the system. A new internet-based information channel and a new interface between BGC and the clearing participants have been added, which allows the participants to follow their clearing positions in $\mathrm{BGC}$ in real-time via the internet. The number of clearing and settlement cycles per day will be increased in the future and once fully operational, the system will allow for the possibility of real-time clearing and settlement of single retail payments. 
- $\quad$ The Riksbank and the major banks have established a working group to elaborate on a strategy for a future central settlement system in Sweden. The chairman of the working group is a representative from one of the major banks.

90. Sweden has an advanced, complex and overall sound financial system. The Swedish money, securities and foreign exchange market are well developed, liquid and efficient. The RIX-system forms the heart of these financial markets while mostly all transactions in these wholesale market as well as monetary policy operations are settled via the RIX-system which is well shaped, efficient, safe and fully automated. The RIX-system operates in accordance with the Real Time Gross Settlement (RTGS) principle. Payments are settled one by one and the cash that is transferred to the participants' account with the Riksbank is immediately available. The legal framework in Sweden fully supports the functioning of the RIX-system and all other payment systems. Especially finality of payments and electronic processing are well regulated. No-zero hour-rule exists. The Riksbank offers unlimited intraday credit against a broad range of collateral, which ensures sufficient liquidity during stress-times in the markets.

91. In addition to an incident-organization, charged to deal with problems in the RIXsystem, a crisis-committee exists within the Riksbank to handle crisis-situations in the financial markets. In this committee as well as employees and officials of the operational payment department, staff-members of the separate financial stability department, as well as from monetary department are involved. Decisions can be taken in a timely manner and with sufficient authority. Crisis-handling is tested regularly. In case of serious liquidity problems the Riksbank can decide to support a illiquid but solvent bank and grant liquidity against special terms and conditions, which might imply that loans granted under the emergency liquidity arrangement (ELA) are not fully collateralized.

92. Potential systemic risk and contagion risk might occur in the financial infrastructure due to the absence of adequate risk management measures in both netting schemes for settlement of securities transactions of VPC. Both systems final settle in the RIX-system. Adequate measures that prevent an unwinding and could deal with market risk and liquidity risk that might occur in the event that the participant with the largest positions is unable to settle its obligations should be developed.

93. The oversight of payments system is not always clear and transparent for payment system providers and market participants because the scope of oversight/supervision of the Riksbank and Finansinspectionen overlaps. Other concerns are (i) the lack of regulatory powers of the Riksbanks, which hampers the effectiveness of the Riksbanks'oversight and (ii) the lack of explicitly formulated objectives and the not coming up to the mark of the present supervisory approach of Finansinspectionen in dealing with the various risks in payment and securities settlement systems and especially with systemic risk.

94. Counterparty risk in the interbank markets, especially in the foreign exchange market and in the money market, could be reduced by promoting collaterization of interbank loans. The use of collateral in the interbank market could be facilitated by developing a full 
automated trade for trade settlement system for securities transactions that settles transactions on a real time basis and is capable to handle the settlement of repo-transactions, including the reversed transaction at the agreed point in time.

95. An aspect that hampers the efficiency is the small time-window during which banks have to settle specific payment related to transactions of foreign customers. This causes liquidity stress during this peak-time and banks sometimes block all outgoing payments to ensure available liquidity during this time window. The time window is agreed upon in code of conduct between banks. Although the situation has already improved, further improvements might be possible by adapting the code of conduct and/or by introducing incentives for early settlement of payments.

\section{Main Findings-Summary}

\section{- $\quad$ Legal foundation (CP I)}

The RIX-system has a well-founded legal basis and principle I is fully observed. In Sweden the European finality directive is incorporated in law by the approval of the Settlement System Act. Within the framework of this law the RIX-system is notified to the European Commission as a designated payment system. In a notified system in Sweden transfer orders vis-à-vis a third party shall be valid notwithstanding that a collective insolvency procedure has been started, provided that such orders were been placed in the system prior to the issuance of the decision with respect to the insolvency procedure. In Sweden there are no judicial hinders to citing electronic documentation in a court of law. This is recently codified explicitly by the act on qualified electronic signatures. The rules and regulations of the RIX-system are transparent and the right and obligations of all involved parties are clearly stated;

\section{- Understanding and management of risks (CPs II-III)}

Both core principles II and III are fully observed. A clear description of the functioning of the RIX-system and its key roles can be found in the publication of the Riksbank 'Settlement of payments in the RIX-system, SKR and EURO'. The RTGScharacter of the RIX-system reduce overall systemic risk. The RIX-system has a waiting queue and participants can actively manage their liquidity position. The Riksbanks extends intra-day credit to qualified participants and accepted a broad range of collateral to avoid gridlocks in the systems. However, the amount of credit available to the market is limited for the E(uro)-RIX-system due to the fact that Sweden has not joined the Economic and Monetary Union (EMU) so far. In emergency situations the Riksbank is allowed to grant credit or provide guarantees on special terms with the end of supporting liquidity in the system (Sveriges Riksbank act, $\S 6: 8$.);

\section{- $\quad$ Settlement (CPs IV-VI)}

The Core principles with respect to settlement are fully observed. Due to the RTGScharacter of the RIX-system no netting of transactions takes place. Settlement is being effected throughout the day. A payment in the RIX-system becomes final for 
the sending participant when its account is debited and for the receiving participant when its account is credited. The receiving participant can immediately use the received cash. After the transaction is final the payment order cannot be revoked, reversed or make void by the sending participant or by any third party, or even in the event of insolvency procedures against a participant, except in cases of imperfections in the underlying transaction(s) or payment order(s) arising from criminal offences or fraudulent acts. The settlements takes place in central bank money as well in kronor as in euro and no settlement bank risk occurs;

\section{Security and operational reliability, and contingency arrangements (CP VII)}

The operational reliability of the RIX-system is very high and contingency measures and measures to prevent unauthorized access are up to standard. Data integrity, authorization, authentication, non-repudiation and confidentiality are ensured. Adequate procedures are in place concerning procurement, development and modification to ensure that current production processes are not disturbed;

\section{Efficiency and practicality of the system (CP VIII)}

Although the RIX-system is efficient, fully automated and well-shaped, core principle VIII is only broadly observed. The main reason for this is that the RIX-system is not fully cost recovering due to the small number of payments in a highly concentrated banking sector and due to the fact that Sweden, in order to be able to join the EMU, has to operate two systems one that settles in kronor and in one in euro. However, the Riksbank is fully aware of this problem and develops at the moment, in cooperation with banking sector, a longer-term strategy to broaden the economic base. Inter-alia outsourcing of the operational tasks the Riksbank to the private sector and cooperation with other central banks in Nordic countries will be examined.

\section{- $\quad$ Criteria for participation (CP IX)}

The RIX-system has objective and publicly disclosed access criteria, permitting fair and open access. However, in order to reduce the strong concentration risk in especially the securities markets it might be recommendable that the Riksbank evaluate its access criteria for the RIX-system and allow also access to all investment firms. However, broadening of the access criteria will only make sense if the annual fee of SKR 200.000 is lowered substantially, while this fee is too high a threshold for smaller banks and investment firms;

\section{- $\quad$ Governance of the payment system (CP X)}

Although the Riksbank fully owns the RIX-system, the banking sector and other relevant participants participate on different levels in the adaptation of the present system and the development of a strategy for a new generation large value system;

\section{- Central Bank Responsibilities in applying the CPs}

The Riksbank has fully disclosed its oversights role in the articles published in the Financial Market Report 1997-01 and in the Sveriges Riksbank Economic Review 
2001. A specific department, the financial stability department, is created and charged with the analysis of the financial stability and the oversight of the financial infrastructure. Part of the oversight task is to ensure that the RIX-system fully complies with the core principles. Weaker points are that the Riksbank has no power to enforce compliance and can give no regulations with respect to safety and efficiency of payment systems in Sweden. At the moment there exist no regulatory framework in which the core principles are worked out. Also the overlap with the supervision of Finansinspectionen and the lack of a memorandum of cooperation between this two institutions makes it difficult for the market to know what the requirements are and how the requirements of the two overseers/supervisors do cohere and who controls what.

\section{ObSERVANCE OF CPSS CORE PRINCIPLES FOR SYSTEMATICALly IMPORTING AND PAYMENT SYSTEMS}

\section{Principle I-The system should have a well-founded legal basis under all relevant jurisdictions.}

Description

The Sveriges Riksbank Act forms the legal basis for the payment system. The Act states that the Riksbank shall, inter alia, 'promote a safe and efficient payment system and may provide settlement system facilities and participate in the settlement of payments. The Act allows the Riksbank to grant intra-day credit to participants. There are nine principal laws in Sweden that form the legal framework for the functioning of clearing and settling transactions under the Settlement Systems Act, which governs the registration and approval of systems used for clearing and settling transactions with financial instruments. Within the framework of this law, the RIX-system is designated by the European Commission as a designated payment system. In a designated system transfer orders vis-àvis a third party shall be valid, notwithstanding that a collective insolvency procedure has been started, provided that such orders were been placed in the system prior to the issuance of the decision with respect to the insolvency. Swedish laws recognize the validity of electronic processing of payments. There are no judicial obstacles to citing electronic documentation in a court of law. This is recently codified by the act on qualified electronic signatures.

The RIX-system settles large value payments in Swedish Kronor (K-RIX) and in eurodenominated payments (E-RIX). In E-RIX payments in euro between participants in the system are settled, as well as cross-border payments between the Swedish participants and participants in other systems that forms part of TARGET (Trans-European Automated Gross Settlement Express Transfer System). TARGET connects the 15 RTGS-systems in the 15 member countries of the European Union and the payment system of the European Central Bank (ECB). All connected payments systems have to fulfill the requirements set out in the TARGET guidelines (PSS/97/479, version 2.01, November 1997). The rules and regulations of the RIX system are based on these guidelines and the multilateral agreement on TARGET concluded between the ECB and the National Central Banks of the European Union. They have to be accepted by the ECB. Changes in rules and regulations are subjected to the approval of the Governing Board of the ECB.

The rules and regulations of the RIX system has been updated recently (June 1, 2001) and published. They can also be downloaded from the internet. The rules and regulations of this system, and the credit arrangement between the Riksbank and the participant govern the granting of credit within the RIX-system. All credit has to be fully collateralized. The 


\begin{tabular}{|l|l|}
\hline & $\begin{array}{l}\text { requirements for collateral accepted are specified by the Riksbank and published. } \\
\text { Collateral for intra-day credit and for standing overnight facilities has to be pledged } \\
\text { according to the pledge agreement for credit in RIX. }\end{array}$ \\
\hline Observed
\end{tabular}

CP III-The system should have clearly defined procedures for the management of credit risks and liquidity risks, which specify the respective responsibilities of the system operator and the participants and which provide appropriate incentives to manage and contain those risks.

\begin{tabular}{l|l} 
Description & The RIX system is a RTGS-system. The implementation of this design substantially
\end{tabular} reduces overall systemic financial risk arising from the settlement of large value payments in Swedish Kronor as well as in euro-denominated payments. The rules and regulations and related documentation set out the details of common policies and procedures for RIX including credit and liquidity management policies and procedures. The openings-times and certain cut off times are included in an appendix to the rules.

As mentioned the Riksbank extends intra-day credit to qualified participants of the RIXsystem to avoid gridlocks in the system. Under normal circumstances in the K-RIX system the credit line is limited to the value of the collateral pledged. In the system for the settlement of euro-payments the total of intra-day credit granted to all participants together may not exceed euro 0,5 billion. The Riksbank decides in a special procedure how the access to intra-day credit in E-RIX shall be distributed among the participants and on the allocation of costs associating with the credit processing. The Riksbank has the right to withdraw the participants access to the credit facility in emergency situations, if necessary.

The Riksbank accepts a broad range of collateral including debt instruments denominated in foreign currency. Also foreign currency may be accepted as collateral for credit in Swedish Kronor. The Riksbank manages the credit risk by requiring that the debt instruments accepted as collateral have been issued by a central bank, public body or company that has a satisfactory credit rating. The debt instrument should also have an acceptable liquidity. Further, the country in which the issuer is domiciled as well as the currency in which the collateral is issued should have a satisfactory credit standard. The Riksbank imposes haircuts on collateral and values the collateral according to actual market prices on a daily basis. If needed, additional collateral can be required if market value is less than the amount of credit paid out.

In exceptional circumstances, the Riksbank may, in order to support liquidity in the system if the operations in the large value payment system are interrupted or a solvent bank faces liquidity, grant credit or provide guarantees on special terms to banking institutions and Swedish companies that are under the supervision of the FI (Provision on the Emergency Liquidity Assistance (ELA), Sveriges Riksbank act, §6:8).

The RIX-system allows participants to monitor incoming and outgoing payments flows and the liquidity in the account on-line. Participants can schedule their payments flows, and watch and manipulate payments in the waiting queue in order to manage actively their 


\begin{tabular}{|c|c|}
\hline & $\begin{array}{l}\text { liquidity position. Between the largest banks an arrangement is in place in which intra-day } \\
\text { liquidity can be borrowed for a maximum of } 4 \text { hours without any fee. Banks can bring in } \\
\text { fresh collateral on the same day but it will take sometimes up to one hour before the } \\
\text { transfer order to VPC will result in enlargement of the credit limit in the RIX system. }\end{array}$ \\
\hline Assessment & 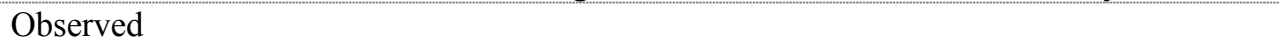 \\
\hline Comments & $\begin{array}{l}\text { The broad range of collateral and the acceptance of collateral in foreign currency make it } \\
\text { easier for banks to get liquidity from the central bank, especially if banks are very active } \\
\text { abroad or if the participant is a branch of a foreign bank. For this reason, shortage of } \\
\text { collateral is not an actual threat for the system even if the outstanding government debt } \\
\text { might be reduced in the longer term in Sweden. } \\
\text { Some banks have asked for automation of the present manual handling of taking in } \\
\text { collateral or delivering it out and adapting the credit-lines accordingly in the RIX-system } \\
\text { made it possible to bring in or withdraw almost on-line real-time collateral that might in } \\
\text { the latter case be needed for commercial transactions. The Riksbank has scheduled an IT- } \\
\text { project for next year to realize this. }\end{array}$ \\
\hline \multicolumn{2}{|c|}{$\begin{array}{l}\text { CP IV-The system should provide prompt final settlement on the day of value, preferably during the day } \\
\text { and at a minimum at the end of the day. }\end{array}$} \\
\hline Description & $\begin{array}{l}\text { The RIX-system is a real-time gross settlement system, which means that the settlement } \\
\text { takes place throughout the day whenever a payment is accepted by the system. In RIX, a } \\
\text { payment will only be accepted if the paying bank has sufficient funds or credit on its } \\
\text { account with the Riksbank. } \\
\text { According to the TARGET guidelines finality means that the settlement order cannot be } \\
\text { revoked, reversed or made void by the sending NCB/ECB, by the sending participant or } \\
\text { by any third party, or even in the event of insolvency proceedings against a participant, } \\
\text { except in cases of imperfections in the underlying transaction(s) or payment order(s) } \\
\text { arising from criminal offences or fraudulent acts. } \\
\text { A payment in RIX becomes final for the sending participant when its account is debited } \\
\text { and for the receiving participant when its account in RIX is credited. This means that the } \\
\text { participants are able to pass on customer payments they receive to the final beneficiary } \\
\text { immediately and without credit risk. }\end{array}$ \\
\hline Assessment & Observed \\
\hline Comments & None \\
\hline
\end{tabular}

$C P V-A$ system in which multilateral netting takes place should, at a minimum, be capable of ensuring the timely completion of daily settlements in the event of an inability to settle by the participant with the largest single settlement obligation.

\begin{tabular}{|l|l|}
\hline Description & The RIX-system is a RTGSSystem \\
\hline Assessment & Not applicable \\
\hline Comments & None \\
\hline
\end{tabular}

CP VI-Assets used for settlement should preferably be a claim on the central bank; where other assets are used, they should carry little or no credit risk and little or no liquidity risk.

\begin{tabular}{l|l}
\hline Description & The RIX-system settles in central bank money as well as in Kronor as in Euro. \\
\hline Assessment & Observed \\
\hline Comments & None
\end{tabular}

CP VII-The system should ensure a high degree of security and operational reliability and should have contingency arrangements for timely completion of daily processing.

Description 


\begin{tabular}{|c|c|}
\hline & 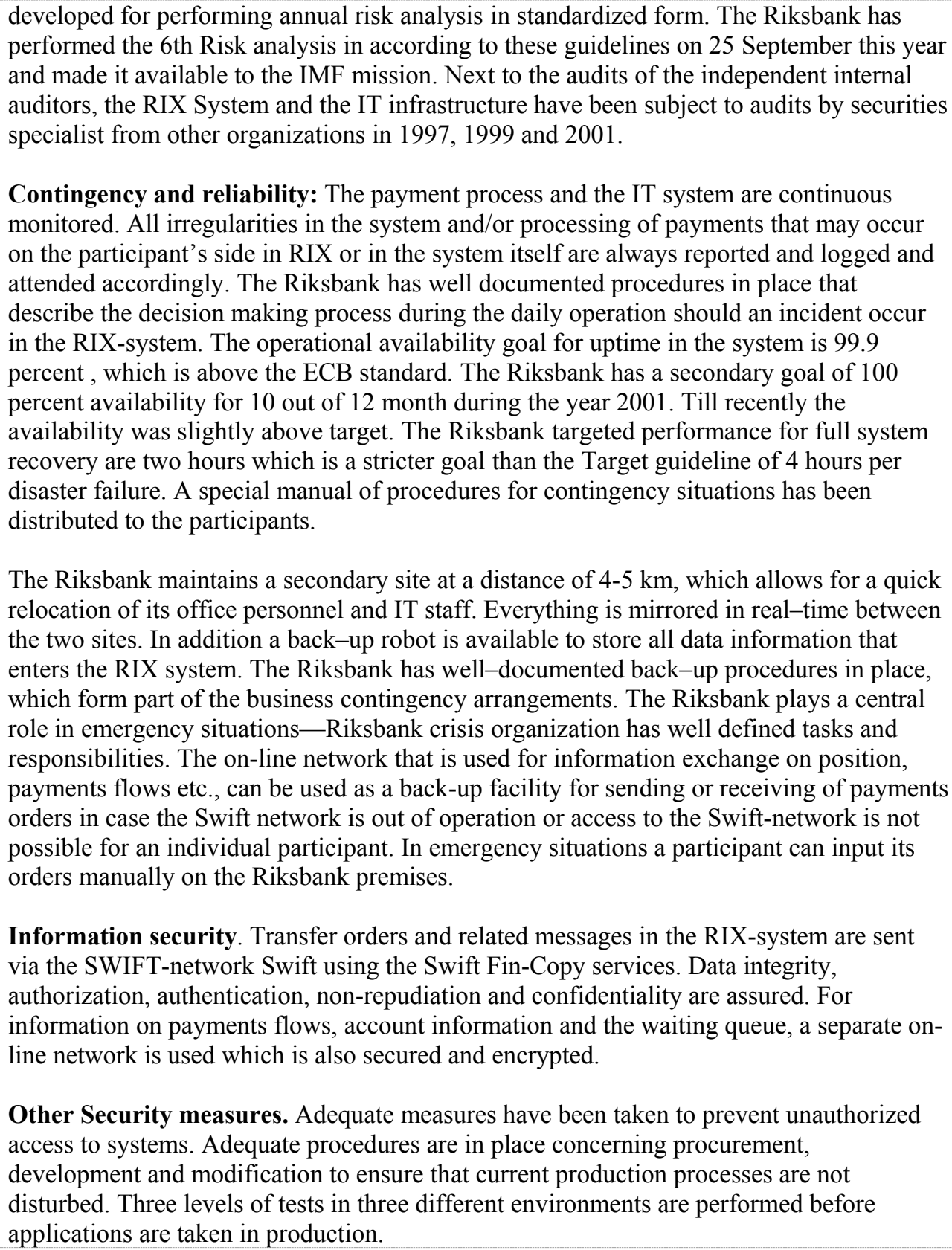 \\
\hline Assessment & Observed \\
\hline Comments & None \\
\hline \multicolumn{2}{|c|}{$\begin{array}{l}\text { CP VIII-The system should provide a means of making payments, which is practical for its users and } \\
\text { efficient for the economy. }\end{array}$} \\
\hline Description & $\begin{array}{l}\text { Cost and pricing. The RIX-system is not fully cost-recovering due to the small numbers } \\
\text { of payments in a concentrated banking sector. The Riksbank is fully aware of this problem } \\
\text { and developing, in cooperation with the banking sector, a long-term strategy to broaden } \\
\text { the system's economic base. The outsourcing of the operational tasks of the Riksbank by } \\
\text { integrating the large value and the retail payment systems is being examined. The } \\
\text { cooperation and integration of the large value systems of the central bank in the Nordic } \\
\text { countries might be another possible option to broaden the economic base, share }\end{array}$ \\
\hline
\end{tabular}




\begin{tabular}{|l|l|}
\hline \multirow{1}{*}{ Assessment } & $\begin{array}{l}\text { development costs and future IT investments when the present system has to be replaced } \\
\text { by a more modern system. } \\
\text { Efficiency. In the short term efficiency will be enhanced by changing the code of conduct } \\
\text { between banks and settlement of payments related to transactions of foreign customers } \\
\text { above a certain amount on a gross basis in the K-RIX-system. At the moment these } \\
\text { payments are accumulated in one amount, that, according to the code of conduct. should } \\
\text { be paid within the RIX-system at a specific moment of the day. The limit for an individual } \\
\text { payment of this type has been lowered in steps to SKR 500.000 in the beginning of } 2002 . \\
\text { This has reduced the liquidity stress in the system and will enlarge the efficiency by } \\
\text { lowering necessary amount of collateral in relation to the turnover in the system. } \\
\text { Broadly observed }\end{array}$ \\
$\begin{array}{l}\text { It might be worthwhile to examine, whether the efficiency could be enhanced and the } \\
\text { liquidity stress during peak times could be reduced even more by broadening the time } \\
\text { window in which foreign customers related payments have to be settled. The times at } \\
\text { which the kronor leg of FX-transaction in the RIX-system must be settled could be } \\
\text { brought more in line with the times in which the other currency is settled. For instance the } \\
\text { Kronor leg of FX deals in Asian currency could be settled early in the morning and the } \\
\text { Kronor transaction related to dollar transaction in the afternoon. To avoid the free rider } \\
\text { problem around liquidity that makes the banks reluctant to liberalize the code of conduct } \\
\text { further, the Riksbank could examine whether there should be minimum requirements for } \\
\text { the amount of collateral that should be deposited in relation to the individual turnover of a } \\
\text { participant. } \\
\text { A price incentive that would stimulate the earlier input and settlement of payments in the } \\
\text { system could also be explored. }\end{array}$ \\
\hline
\end{tabular}

CP IX-The system should have objective and publicly disclosed criteria for participation, which permit fair and open access.

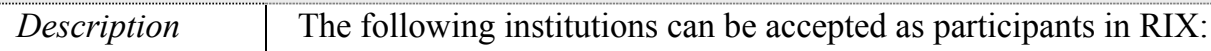

- Credit institutions;

- Investment firms on condition that the firm is permitted to carry out trading with financial instruments on behalf of others in its own name or on its own account, or provide guarantees in connection with issues of securities and that the firm is a counterpart (primary dealer) in the Riksbank's operation on the money market;

- Clearing organizations;

- Treasury departments and public bodies that are responsible for a state's payment and cash settlement.

The Riksbank is open for remote access participants and the Riksbank may also accept a foreign central bank as a participant in K-RIX. In accordance with the Target Guidelines in the case of remote access, a legal opinion is required.

In the rules and regulations, there are defined prerequisites for exclusion or suspension from the RIX-system.

Assessment

Comments

All these criteria are applied in a non-discriminatory manner.

Observed

Only investment firms that are eligible counterparties in the Riksbank's open market operations have access to the RIX-system. The eligibility of counterparties in monetary operations is very restricted and only one investment firm fulfills the access criteria.

Due to the strict access criteria for the RIX-system investment firms generally use a settlement bank. This exacerbates the concentration risk in the Swedish financial system. 


\begin{tabular}{|c|c|}
\hline & $\begin{array}{l}\text { For this reason, it is recommended that the Riksbank evaluate its access criteria and } \\
\text { consider whether access should be given to all supervised investment firms and whether } \\
\text { they should be granted access to intra-day credit facilities. This would be also more in line } \\
\text { with the proposals for the new EU investment directive. However, a broadening of the } \\
\text { access criteria in the aforementioned way will only make sense if the annual fee of SKR } \\
200.000 \text { is lowered substantially-while this fee is too high a threshold for investment } \\
\text { firms and smaller banks. An alternative to allowing broader participation could be to } \\
\text { restrict the services for this type of clients to the clearing and settlement of securities and } \\
\text { set special tariffs for this. }\end{array}$ \\
\hline \multicolumn{2}{|c|}{ CP X-The system's governance arrangements should be effective, accountable and transparent. } \\
\hline Description & $\begin{array}{l}\text { The Riksbank owns the RIX-system ( } 100 \text { percent). The Riksbank strategic objectives are } \\
\text { focusing on reduction of risk in the financial system, promoting efficiency, cost } \\
\text { recovering and a client and service orientated organization. For the short term there are } \\
\text { detailed business plans on development of systems, which are developed after consultation } \\
\text { with all relevant parties including the system overseer. Within the Riksbank there are clear } \\
\text { lines of responsibility and, thorough planning and budgets instruments, there is a direct } \\
\text { accountability to the board of the Riksbank. There is an independent internal audit } \\
\text { department and the RIX-system is overseen by a separate division within the Riksbank- } \\
\text { the financial stability department. Through comparison with the central banks within the } \\
\text { EU, management has an incentive to ensure that the system's objectives are realized. Long } \\
\text { term strategies and other important aspects are discussed in the payments system } \\
\text { committee in which the chief financial officers of the banking sector, VPC and } \\
\text { Stockholmbörsen participate. User groups are discussing current issues in the RIX-system } \\
\text { and are involved in the testing of new system releases. }\end{array}$ \\
\hline Assessment & Observed \\
\hline Comments & None \\
\hline \multicolumn{2}{|r|}{ Central Bank Responsibilities in Applying the CPSIPS } \\
\hline \multicolumn{2}{|c|}{$\begin{array}{l}\text { Responsibility A-The central bank should define clearly its payment system objectives and should disclose } \\
\text { publicly its role and major policies with respect to systemically important payment systems. }\end{array}$} \\
\hline Description & $\begin{array}{l}\text { The objectives of the Riksbank with respect to the oversight of payment system are stated } \\
\text { in article } 2 \text { of the Sveriges Riksbank Act (1988:1385) in which the Riksbank is charged } \\
\text { with the responsibility to promote a safe and efficient payment system. The Riksbank has } \\
\text { recently published an article in the Sveriges Riksbank Economic Review on the } \\
\text { Riksbank's oversight of the financial infrastructure }{ }^{4} \text {. In this article the policy of the } \\
\text { Riksbank and its role are disclosed. }\end{array}$ \\
\hline Assessment & Observed \\
\hline Comments & None \\
\hline
\end{tabular}

Responsibility B-The central bank should ensure that the systems it operates comply with the core principles.

Description

The Financial stability department oversees the RIX-system, taking into account the core principles in their assessment.

Assessment $\quad$ Observed

Comments $\quad$ None

Responsibility C-The central bank should oversee observance with the core principles by systems it does not operate and it should have the ability to carry out this oversight.

${ }^{4}$ Sveriges Riksbank Economic Review, Sveriges Riksbank,2001/3. 


\begin{tabular}{|c|c|}
\hline Description & $\begin{array}{l}\text { The Riksbank is charged with the oversight of payment systems but has no legal power to } \\
\text { enforce compliance with its objectives and has to rely on moral suasion. Also } \\
\text { Finansinspectionen is involved in the supervision of payment system providers outside the } \\
\text { Riksbank. This overlapping responsibilities causes in-transparency. }\end{array}$ \\
\hline Assessment & Partly observed \\
\hline Comments & $\begin{array}{l}\text { Consideration should be given to enhancing the Riksbank's legal powers to issue } \\
\text { regulations on payment systems and on clearing and settlement systems for securities. } \\
\text { This might be done by re-instating in the Sveriges Riksbank Act the legal powers to give } \\
\text { regulations, as they exist in the past. } \\
\text { To avoid in-transparency and promote the efficiency it is recommendable that the } \\
\text { Riksbank and the Finansinspectionen develop: } \\
\text { - An explicit regulatory framework in which the objectives are stated and the } \\
\text { international codes and standards are reflected. This framework should also include } \\
\text { existing obligations, a fit and proper test for the management of payment systems, the } \\
\text { information requirements and the involvement of the overseers in crisis situations; } \\
\text { An explicit framework for cooperation, division of tasks and information sharing. } \\
\text { This should be written out in a Protocol on cooperation or a MOU. }\end{array}$ \\
\hline \multicolumn{2}{|c|}{$\begin{array}{l}\text { Responsibility D-The central bank, in promoting payment system safety and efficiency through the core } \\
\text { principles, should cooperate with other central banks and with any other relevant domestic or foreign } \\
\text { authorities. }\end{array}$} \\
\hline Description & $\begin{array}{l}\text { The Riksbank participates in relevant working groups (BIS, ESCB, EU). The Riksbank } \\
\text { further on notifies foreign authorities, especially central banks, about issues that can effect } \\
\text { them. }\end{array}$ \\
\hline Assessment & Observed \\
\hline Comments & None \\
\hline
\end{tabular}

Table 10. Summary observance of CPSS Core Principles and Central Bank Responsibilities in applying the CPs-RIX- system

\begin{tabular}{|l|l|l|}
\hline \multirow{2}{*}{ Assessment grade } & \multicolumn{2}{|c|}{ Principles grouped by assessment grade } \\
\cline { 2 - 3 } & \multicolumn{1}{|c|}{ Count } & \multicolumn{1}{c|}{ List } \\
\hline Observed & $8+3$ & CP 1,2,3,4,6,7,9,10 Responsibilities A, B and D \\
\hline Broadly observed & 1 & CP 8 \\
\hline Partly observed & 1 & Responsibility C \\
\hline Non-observed & & \\
\hline Not applicable & 1 & CP 5 \\
\hline
\end{tabular}




\section{A. Recommended Actions and Authorities' Response to the Assessment}

Table 11. Recommended actions to improve observance of CPSS Core Principles and Central Bank Responsibilities in applying the CPs- RIX-system

\begin{tabular}{|c|c|}
\hline Reference principle & Recommended action \\
\hline $\begin{array}{l}\text { Legal foundation } \\
\text { i.e., } C P I \\
\text { e.g.,, } C P \text { I-The system should have a } \\
\text { well-founded legal basis under all relevant } \\
\text { jurisdictions. }\end{array}$ & None \\
\hline $\begin{array}{l}\text { Understanding and management of risks } \\
\text { i.e., } C P S I I-I I I\end{array}$ & None \\
\hline $\begin{array}{l}\text { Settlement } \\
\text { i.e., } C P S I V-V I\end{array}$ & None \\
\hline $\begin{array}{l}\text { Security and operational reliability, and } \\
\text { contingency arrangements } \\
\text { i.e., } C P V I I\end{array}$ & None \\
\hline \multicolumn{2}{|l|}{ Efficiency and practicality of the system } \\
\hline i.e., $C P$ VIII & $\begin{array}{l}\text { Strengthening the efficiency of the system by broadening the } \\
\text { timeframe for the settlement of foreign clients or FX related } \\
\text { payments ( banking sector has to change the code of conduct). } \\
\text { Investigate incentives to minimize the free rider problem with } \\
\text { respect to liquidity and the input of collateral (Riksbank). } \\
\text { Investigate incentives (differentiation of fees, schedule of } \\
\text { percent age of payments to be done before specific moments } \\
\text { of time during the day etc.) to promote a more smooth } \\
\text { payment flow during the day and to reduce the liquidity stress } \\
\text { during peak hours (Riksbank). }\end{array}$ \\
\hline $\begin{array}{l}\text { Criteria for participation } \\
\text { i.e., } C P I X\end{array}$ & $\begin{array}{l}\text { Evaluate access criteria and fee structure in order to reduce the } \\
\text { concentration and contagion risk in the securities settlement } \\
\text { business (Riksbank). }\end{array}$ \\
\hline $\begin{array}{l}\text { Governance of the payment system } \\
\text { i.e., } C P X\end{array}$ & None \\
\hline $\begin{array}{l}\text { Central Bank Responsibilities in applying } \\
\text { the CPs }\end{array}$ & $\begin{array}{l}\text { Strengthen the legal basis for the oversight task of the } \\
\text { Riksbank (parliament). } \\
\text { Develop an explicit regulatory framework for the oversight of } \\
\text { payment systems in which the objectives of the oversight are } \\
\text { stated and the international codes and standards are reflected } \\
\text { and the involvement of the overseers in crisis-situations is } \\
\text { incorporated (Riksbank/ Finansinspectionen). }\end{array}$ \\
\hline i.e., Responsibilities $A-D$ & $\begin{array}{l}\text { Develop a protocol on cooperation, division of tasks and } \\
\text { information sharing (Riksbank/ Finansinspectionen). }\end{array}$ \\
\hline
\end{tabular}


Detailed assessment of observance of CPSS/IOSCO Recommendation for Securities Settlement Systems with respect to $\mathrm{VPC}$-system

\section{Recommendation 1-Securities Settlement Systems should have a well-founded, clear and transparent legal basis in the relevant jurisdictions. \\ \begin{tabular}{l|l} 
Description & The legal framework for securities trading, clearing and settlement and custody consist of
\end{tabular} a broad range of laws. The Act of Contracts, the Banking Business Act, the bankruptcy regulations, the Securities Operation Act, the Exchange and Clearing Operations Act, the Trading in Financial Instruments Act, the Financial Instrument Account Act and Settlement System Act. The rules and regulations of VPC complete this legal framework. All laws and regulations are publicly available and the key aspect for clearing and settlement are covered. Because the legal framework is complex, divided over many laws and while the law does not always support market practices there is a lack of transparency, both for outsiders and market participants. This makes it difficult to assess the legal risk. \\ Enforceability of transactions. The Swedish legal system gives adequate protection to counterparties and provides appropriate means to support and effectuate contractual obligations. This includes the rules regarding the liquidations of assets. \\ Protection of customers assets. The Swedish law protects the financial assets of the customer against an insolvency of the central depository or a custodian in Sweden. Immobilization and dematerialization. The Financial Account Act regulates the dematerialization and immobilization in VPC. Dematerialization of financial instrument issued in Sweden is the underlying principal.}

Netting arrangements. Chapter 5, Section 1 of the Financial Instruments Trading Act supports bilateral netting, as well multilateral netting provided that the multilateral netting is performed within a designated settlement system according to the rules of such system. VPC is according to the Settlement System Act such a designated system and is notified as such by Finansinspectionen to the European commission.

Securities lending. Chapter 3, Section 1 of the Financial Instruments Trading Act covers the use of financial instruments belonging to another party. This provision covers all kind of securities loans, buy and sell backs and repos. The law allows the requirement of margin calls during the maturity of a repo.

Finality of settlement. There is no zero hour rule in Sweden. The Financial Instruments Accounts Act Chapter 6, regarding the legal effects of registration on VPC accounts rules the finality of a transfer of securities. A credit of securities account in VPC is final and irrevocable and may not be unwound by any party nor by VPC. The rules and regulations of VPC explicitly stated the moment the crediting of the account takes place. After that no retroactive action is possible, not even in the event of an insolvency of a participant.

Delivery versus payments. The Swedish legal framework supports delivery versus payment procedures explicitly. Blocked securities during a DVP procedure cannot be subject to a claim of a third party (The Financial Instrument Account Act, Chapter 6, Section 2).

The rules addressing the consequences of a participant's default. The rules and regulations of VPC address explicitly the procedures in case of a default of a participant. In that case the clearing is unwound and all the transactions of the defaulting party are cancelled. 


\begin{tabular}{|c|c|}
\hline & $\begin{array}{l}\text { Liquidation of asset pledged. The right to liquidate assets pledged is not automatically } \\
\text { granted by law, but has to be conducted between the relevant parties by contract. } \\
\text { Enforceability of the rules of VPC in case of a default. According to the Settlement } \\
\text { System Act (SFS 1999:1309) a transfer order vis-à-vis third parties in a designated system } \\
\text { shall be valid notwithstanding that a collective insolvency procedure has been commenced } \\
\text { against a participant, provided such orders were placed in the system prior to the issuance } \\
\text { of the decision with respect to the procedure. As was mentioned VPC is such a notified } \\
\text { system. }\end{array}$ \\
\hline Assessment & Broadly compliant \\
\hline Comments & $\begin{array}{l}\text { The legal framework does not fully support existing practices in clearing and settlement } \\
\text { and is not fully transparent. For instance, the legal framework for pledge and custody } \\
\text { makes it difficult to re-pledge collateral from one level to another in a Central Counterparty } \\
\text { construction. As a result, clearing members have to use their own collateral to cover their } \\
\text { clients positions vis-à-vis the central counterparty. This makes the use of central } \\
\text { counterparty construction relatively expensive and hampers the international competitive } \\
\text { position of Swedish clearing organizations in Europe. It might be worthwhile to scrutinize } \\
\text { the legal framework for clearing and settlement and bring it more in line with the current } \\
\text { market practices and the needs of the integration of financial markets in Europe. }\end{array}$ \\
\hline \multicolumn{2}{|c|}{$\begin{array}{l}\text { Recommendation 2-Confirmation of trades between direct market participants should occur as soon as } \\
\text { possible after trade executions, but no later than trade date }(T+0) \text {. Where confirmation of trades by indirect } \\
\text { participants is required, it should occur as soon as possible after trade execution, preferable on } t+0, \text { but no } \\
\text { later than }+1 \text {. }\end{array}$} \\
\hline Description & $\begin{array}{l}\text { According to market rules in Sweden all trades between direct market participants must be } \\
\text { registered in the VPC system within one hour. In the equities market trades have to be } \\
\text { registered before noon on T }+1 \text {. Matching is performed in real-time after the trades are } \\
\text { registered. Unmatched instructions are excluded automatically when the VPC is closed for } \\
\text { reporting of transaction with day S as Settlement day. However, VPC offers a pre-matching } \\
\text { function, which allows for unmatched instruction to be automatically be forwarded one day } \\
\text { until the time they match. These transactions can be forwarded for a maximum of } 20 \\
\text { working days. } \\
\text { In the bond and money market } 100 \text { percent of the trade are confirmed on T }+0 \text { and in the } \\
\text { equity market } 30 \text { percent of the trades on } \mathrm{T}+0 \text { and } 70 \text { percent on } \mathrm{T}+1 \text {. These figures } \\
\text { enclose only the trades between clearing members. There is no central trade confirmation } \\
\text { system between a direct participant and an indirect participant. Normally } \\
\text { custodians/brokers do not use STP to communicate with their clients. }\end{array}$ \\
\hline Assessment & Partly compliant \\
\hline Comments & $\begin{array}{l}\text { Although trade confirmation in the bond and money market occur within the standards set } \\
\text { by the CPSS/IOSCO, the market rules for equities trade should be strengthened. The } \\
\text { information exchange between the clearing members/brokers and their clients especially } \\
\text { with respect to foreign customers requires significant improvement. }\end{array}$ \\
\hline \multicolumn{2}{|c|}{$\begin{array}{l}\text { Recommendation } 3 \text {-Rolling settlement should be adopted in all securities markets. Final settlement should } \\
\text { occur no later than } T+3 . \text { The benefits and costs of a settlement cycle shorter than } T+3 \text { should be evaluated. }\end{array}$} \\
\hline Description & $\begin{array}{l}\text { The Swedish market utilizes a rolling settlement. In general the settlement cycle for stock } \\
\text { exchange as well as for OTC transactions is } \mathrm{T}+3 \text {. Only for short term notes (treasury bills) } \\
\text { the settlement cycle is } \mathrm{T}+2 \text {. Stock exchange transactions and OTC transactions are } \\
\text { normally settled via two netting schemes operated by VPC. One for equities (the so called } \\
\text { Guarantee Clearing) and one for bonds and short term notes (so-called Money Market } \\
\text { Clearing). If a participant fails to deliver no steps are taken to mitigate the market risk or } \\
\text { the liquidity risk for the counterparty. }\end{array}$ \\
\hline
\end{tabular}




\begin{tabular}{|c|c|}
\hline & $\begin{array}{l}\text { VPC also offers a RTGSSystem, but this system is operated manually and in practice } \\
\text { participants hardly use it (only to correct mistakes). A fully automated RTGS system is } \\
\text { deemed to be too costly by the owners of VPC. } \\
\text { The cost of and benefits of a shorter settlement cycle are presently discussed within the } \\
\text { context of the project "New clear." In the New Clear project one of the key questions is } \\
\text { how to prepare for T }+1 \text { settlement. Market participants indicate that shortening would be } \\
\text { problematic due to the cross-border trades which involve a large number of parties that } \\
\text { have to confirm trades and settlements timely. Already at present the primary source of } \\
\text { failures to settle on settlement date is attributable to late instructions from foreign } \\
\text { customers. Also Straight Through Processing (STP) is not widely used in Sweden at } \\
\text { present and the implementation of STP is seen as a primary condition to reduce the } \\
\text { settlement cycle for the clearing members (see also recommendation } 2 \text { ). } \\
\text { Technically, the VPC system can be easily adapted to settle on T+0 in the money market } \\
\text { clearing and on T+1 in the equities clearing. } \\
\text { There are no specific sanctions in VPC on late deliveries. However, VPC publish a } \\
\text { monthly report wherein fail-rates of clearing members are published. When a participant } \\
\text { repeatedly has a high fail rate this information will be common knowledge in the market } \\
\text { and the reputation of this participant can be tarnished to the opinion of VPC. }\end{array}$ \\
\hline Assessment & Compliant \\
\hline Comments & None \\
\hline \multicolumn{2}{|c|}{$\begin{array}{l}\text { Recommendation } 4-\text {-The benefits and costs of a CCP should be evaluated. Where such a mechanism is } \\
\text { introduced, the CCP should rigorously control the risks it assumes. }\end{array}$} \\
\hline Description & $\begin{array}{l}\text { For the clearing and settlement of spot market and repo transactions there is no central } \\
\text { counter party in Sweden. VPC as system provider does facilitate clearing and settlement } \\
\text { but does not take any responsibility for delivery or payments, nor does it guarantee } \\
\text { transactions. Although OM Stockholmbörsen offers central counterparty services, this is } \\
\text { for derivatives only. } \\
\text { The regulatory authorities have been very positive towards a central solution in their } \\
\text { public communication. A central counterparty could, if proper designed, reduce the } \\
\text { present systemic risk that exist in the present netting schemes operated by VPC (see } \\
\text { recommendation 9). } \\
\text { VPC discussed the CCP construction with different parties: } \\
\text { - Within the aforementioned project 'New Clear' the major users and owners of VPC } \\
\text { are discussing, next to the questions of T+1 and how to build more efficient links with } \\
\text { foreign CSDs, the introduction of a CCP construction within VPC. However market } \\
\text { participants indicate that there is no need for a CCP; } \\
\text { Different institutions in the Swedish financial market are exploring the establishment } \\
\text { of a domestic CPP, a Nordic CPP or of providing links to existing European CPPs. } \\
\text { Within the context of the integration of the Nordic Financial markets a CCP or a } \\
\text { range of CCPs (Nordic Clear) are being considered as solutions for the settlement of } \\
\text { cross-border transactions, which might substantially increase when financial } \\
\text { instruments in one country could be traded on the trading platforms in the other } \\
\text { Nordic countries. }\end{array}$ \\
\hline Assessment & Compliant \\
\hline & \\
\hline
\end{tabular}


Recommendation 5 -Securities lending and borrowing (or repurchase agreements and other economically equivalent transactions) should be encouraged as a method for expediting the settlement of securities transactions. Barriers that inhibit the practice of lending securities for this purpose should be removed.

\begin{tabular}{|c|c|}
\hline Description & $\begin{array}{l}\text { There is a well functioning security lending market. Short selling which is explicitly } \\
\text { allowed influences borrowing demands. Especially larger banks are active in this market } \\
\text { and offer lending and borrowing facilities. Also a subsidiary of the Stockholmbörsen } \\
\text { Lendtech facilitates lending and borrowing. Lendtech acts as an intermediary between the } \\
\text { lender and borrower of equities. Especially in the upper tier of the stock index a wide } \\
\text { range of stocks are lent out by major institutional investors to a group of counterparties } \\
\text { approved by the lender. } \\
\text { As was indicated in recommendation } 1 \text { the legal framework fully supports lending and } \\
\text { borrowing. There is since } 1992 \text { also a clear interpretation of the tax consequences of } \\
\text { securities lending. }\end{array}$ \\
\hline Assessment & Compliant \\
\hline Comments & None \\
\hline
\end{tabular}

Recommendation 6 -Securities should be immobilized or dematerialized and transferred by book entry in CSDs to the greatest extent possible.

\begin{tabular}{l|l} 
Description & $\begin{array}{l}\text { All securities, issued in Sweden and held via VPC are dematerialized. Some foreign } \\
\text { securities registered in VPC are immobilized. In these case the global certificate is kept } \\
\text { under custody with a foreign CSD or custody bank. All VPC registered securities except } \\
\text { premium lottery bonds are fungible. }\end{array}$
\end{tabular}

Securities are transferred and pledged by book-entry only. Crediting of the account of the beneficial owner or its custodian makes the transfer of ownership final and irrevocable. There is no underlying register outside the VPC and no time lag between settlement and registration of the ownership.

Swedish law rules the transfer of securities in VPC and the custody of securities directly held via VPC or via a Swedish custodian.

VPC is the only CSD in Sweden.

Through its direct contractual relationship with all issuers of securities registered in the VPC-system, VPC ensures that the total number of securities registered on the VPC accounts equals the total number of securities issued. In the case of shares also checks with the Patent and Registration Office (PRV) on a continuous basis that the amount of shares issued equals the total numbers of shares in the register of PRV.

Assessment Compliant

Comments None

Recommendation 7-CSDs should eliminate principal risk by linking securities transfers to funds transfers in a way that achieves delivery versus payment.

Description

According to VPC rules and regulations, all settlements against payments instructions are conducted on a DVP basis.

VPC operates a model 2 DVP system (settlement of the securities on a gross basis and settlement of cash in the RIX-system on a netting basis). The DVP procedures are safe and eliminate principle risk. Securities are blocked in the account of the seller prior to the cash settlement and are immediately delivered after the cash settlement has taken place. As was mentioned in recommendation 1 the legal framework for this DVP is sound.

VPC also operates a model 1 DVP system (Gross settlement of securities and gross 


\begin{tabular}{|l|l|}
\hline & $\begin{array}{l}\text { settlement of cash in the RIX-system). } \\
\text { VPC maintains relationships with major CSDs in Europe. However, no DVP procedures } \\
\text { are used in these links. The transfer of securities takes place on a free of payments basis } \\
\text { and payment has to been done separately. }\end{array}$ \\
& $\begin{array}{l}\text { However, there might be principal risk lower in the clearing chain. A large part of the } \\
\text { clearing and settlement takes place internally on the books of the clearing member/ } \\
\text { payment bank. Whether this takes place on a DVP basis is not clear. Also between the end } \\
\text { investor and the broker market practices bring forward principal risk, while clients often } \\
\text { have to pay their broker, who on his turn has to pay its clearing member before the } \\
\text { delivery of the securities take place. } \\
\text { Compliant }\end{array}$ \\
\hline Assessment & None
\end{tabular}

Recommendation 8-Final settlement should occur no later than the end of the settlement day. Intraday or real time finality should be provided where necessary to reduce risks.

\begin{tabular}{l|l} 
Description & The two netting systems of VPC clears and settle on 12.45 hours. These are however
\end{tabular} deferred settlement system (settlement on $\mathrm{T}+2$ or $\mathrm{T}+3$ )

There is a RTGS settlement system that makes settlement with intraday finality possible throughout the day. However, this system is operated manually and hardly used. As the existing netting system does not require collateral to cover risk in the positions and has at the same time the advantage of liquidity saving, a real incentive for RTGS transaction is lacking. Also the Riksbank does not use the RTGS System for its monetary operation and the collateralizing of intraday credit. For that reasons the urgent need for DVP deliveries at the end of the day is not there while for standing facilities only collateral is used that is pledged in advance to the Riksbank. Pledging of collateral is possible on a continuous basis during the day. Same day settlement of repos are not used frequently while the interbank money market is not secured.

The VPC does not receive provisional transfers via its link with other CSDs that could lead to problems. for RTGS transaction. However, the counterparty risk in the inter-bank market is quite significant and should be reduced to avoid contagion risks. Due to the risk arbitrage the necessary infrastructure for repos that could handle large amount of transaction in an efficient way and which could reduce this counter party risk is, unfortunately, not available. It should be investigated whether incentives to collateralize interbank loans and the implementation of adequate risk management measures in the netting schemes, might broaden the business case for a fully automated RTGS system.

Recommendation 9-CSDs that extend intraday credit to participants, including CSDs that operate net settlement systems should institute risk controls that, at a minimum, ensure timely settlement in the event that the participant with the largest payment obligation is unable to settle. The most reliable set of controls is a combination of collateral requirements and limits

\begin{tabular}{l|l} 
Description & VPC is not party in any transaction, does not extend any intraday or overnight credit to its
\end{tabular} participants and does not offer securities lending facilities. Overdrafts in securities accounts are not allowed in VPC.

Both the netting schemes operated by VPC are unprotected against a failure of a participant.

However the risks in the Money market clearing are more extensive than in the Guarantee 


\begin{tabular}{|c|c|}
\hline & 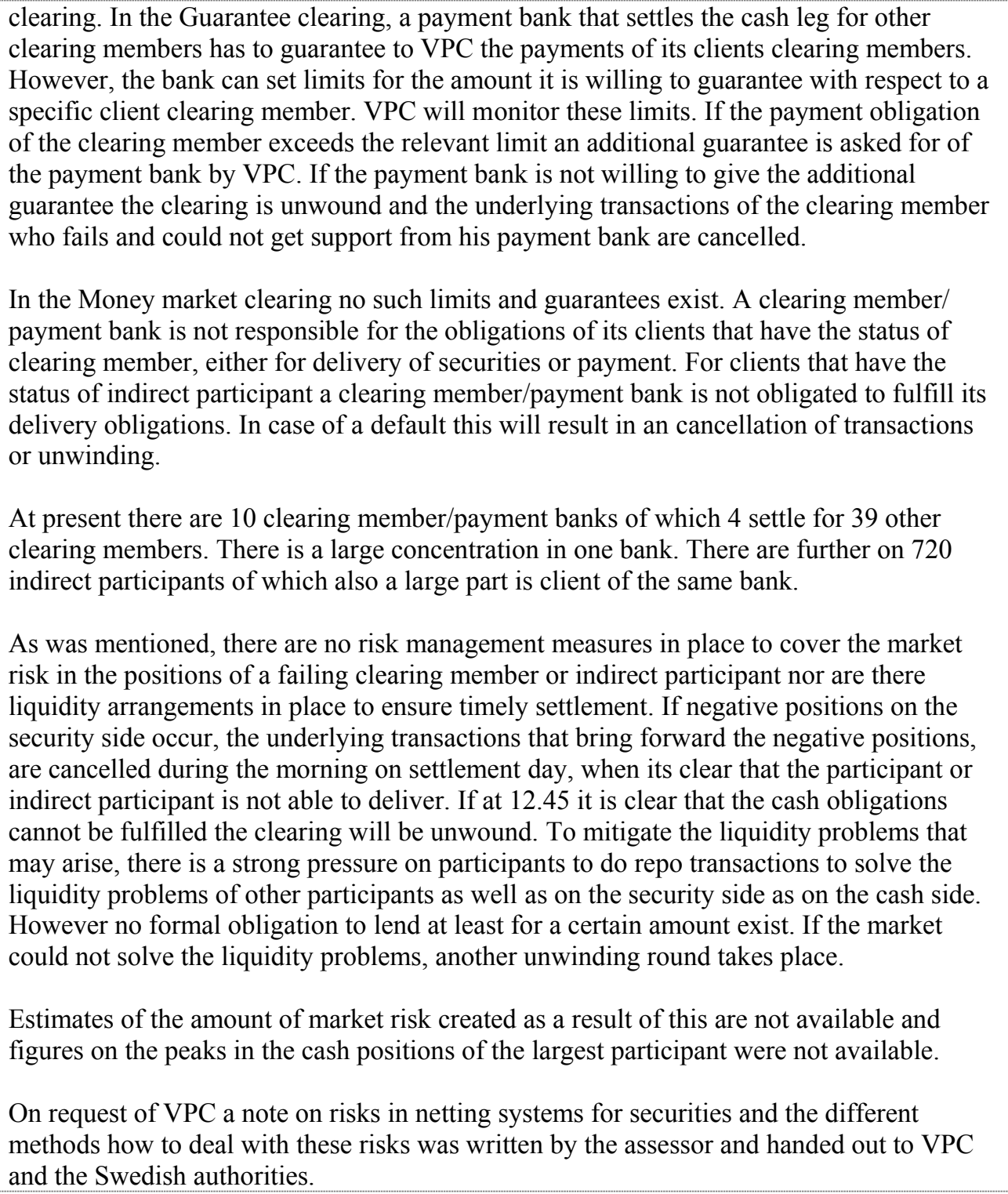 \\
\hline Assessment & Not compliant \\
\hline Comments & $\begin{array}{l}\text { VPC should provide the regulators with figures that make clear what the amount of market } \\
\text { risk is involved in both netting schemes. The liquidity risk in the event that the participant } \\
\text { with the largest cash obligation fails should also be made clear. Such calculations should } \\
\text { be based on stress conditions in the market and assumptions has to be made about the } \\
\text { maximum move in market prices etc. In the calculation the total amount of open positions } \\
\text { should be taken into account (transactions during three market days plus the normal } \\
\text { amount of deferred settlements) } \\
\text { Risk management measures should be implemented on short notice in as well the Equities } \\
\text { clearing as in the Money market clearing to cover the market risk in the positions. Also a } \\
\text { liquidity arrangement should be conducted that makes it possible to settle timely even in } \\
\text { the situation that the participant which the largest cash position fails. } \\
\text { The liquidity risks on the securities side could be reduced, by making clearing members in }\end{array}$ \\
\hline
\end{tabular}




\begin{tabular}{|c|c|}
\hline & $\begin{array}{l}\text { the Money market responsible for the delivery obligations of their clients with the status } \\
\text { of clearing member as well as clients with the status of indirect participant. The same } \\
\text { could be done in the Guarantee clearing for the securities to be delivered by a clearing } \\
\text { member that settles the cash leg via a payment bank. }\end{array}$ \\
\hline \multicolumn{2}{|c|}{$\begin{array}{l}\text { Recommendation 10-Assets used to settle the ultimate obligations arising from securities transactions } \\
\text { should carry little or no credit or liquidity risk. If central bank money is not used steps must be taken to } \\
\text { protect the CSD members from potential losses and liquidity pressure arising from the failure of the cash } \\
\text { settlement agent whose assets are used for that purpose. }\end{array}$} \\
\hline Description & $\begin{array}{l}\text { The cash leg is settled through transfers on the books of the Riksbank. As was mentioned } \\
\text { before this implies only the interbank transfers between the ten payment banks in the VPC } \\
\text { clearing. A large amount of the transactions are settled within the books of the four } \\
\text { payment banks who settle the cash leg for other clearing members, market participants, } \\
\text { foreign customers etc. } \\
\text { Fund transfers in Euro can only be made within certain limits, which are decided by VPC } \\
\text { and the Central Bank jointly. }\end{array}$ \\
\hline Assessment & Compliant \\
\hline Comments & $\begin{array}{l}\text { The strong concentration of cash settlement via four major banks brings forward serious } \\
\text { contagion risk. }\end{array}$ \\
\hline \multicolumn{2}{|c|}{$\begin{array}{l}\text { Recommendation 11-Sources of operational risk arising in the clearing and settlement process should be } \\
\text { identified and minimized through the development of appropriate systems, controls and procedures. Systems } \\
\text { should be reliable and secure, and have adequately, scalable capacity. Contingency plans and back up } \\
\text { facilities should be established to allow for timely recovery of operations and completion of the settlement } \\
\text { process. }\end{array}$} \\
\hline Description & $\begin{array}{l}\text { The operational reliability and operational controls are subject to both VPC internal and } \\
\text { external audits. There is an adequate data management including back up and audit trails. } \\
\text { VPC has three independent operational sites (two operational centers and a back up robot). } \\
\text { The VPC system is synchronously mirrored between the two sites. A restart could be } \\
\text { taken place within one hour. A contingency plan is available. The last years of operations } \\
\text { show very high system reliability (system availability of } 99.99 \text { percent in } 2000 \text {. }\end{array}$ \\
\hline Assessment & Compliant \\
\hline Comments & None \\
\hline \multicolumn{2}{|c|}{$\begin{array}{l}\text { Recommendation 12-Entities holding securities in custody should employ accounting practices and } \\
\text { safekeeping procedures that fully protect customers' securities. It is essential that customers'securities be } \\
\text { protected against the claims of a custodians creditors }\end{array}$} \\
\hline Description & $\begin{array}{l}\text { Financial institutions acting as custodians are supervised by Finansinspectionen. } \\
\text { Customers assets are protected by law against a default of a custodian. Customers are } \\
\text { allowed to open directly an account in their own name in VPC. However, customer asset } \\
\text { could be hold via a custodian, if customers choose to do so. In that case the custodian or } \\
\text { nominee has to open a nominee account in VPC. To prevent comingling of customer's } \\
\text { assets and the asset of the custodian in a nominee account only customer's asset can be } \\
\text { booked. }\end{array}$ \\
\hline Assessment & Compliant \\
\hline Comments & None \\
\hline \multicolumn{2}{|c|}{$\begin{array}{l}\text { Recommendation 13-Governance arrangements for CSDs and CCPs should be designed to fulfill public } \\
\text { interest requirements and to promote the objectives of owners and users. }\end{array}$} \\
\hline Description & $\begin{array}{l}\text { VPC is a private limited company owned by the four largest Swedish banks, which have } \\
\text { each } 24.65 \text { percent of the shares. The other } 1.4 \text { percent is owned by } 15 \text { other banks and } \\
\text { brokers. } \\
\text { The shareholders appoint } 7 \text { members of the Board of VPC. The board members have to be }\end{array}$ \\
\hline
\end{tabular}




\begin{tabular}{|c|c|}
\hline & $\begin{array}{l}\text { accepted by Finasinspektionen (fit and proper test). Two other members of the Board are } \\
\text { representatives of the employees of VPC. } \\
\text { VPCs overall objective are: } \\
\text { - VPC shall be the central link of chose in the chain between of ownership between } \\
\text { the issuer and the investor as soon as at least one of them has Swedish domicile. } \\
\text { VPC is to ensure that the securities for which VPC maintains register are traded and } \\
\text { settled in a system of high international class. } \\
\text { VPC is to meet high international requirements of functionality and security. } \\
\text { VPC is to develop activities in areas that promote the functioning and transparency } \\
\text { of the market. } \\
\text { VPC is to show a level of profitability that is sufficient to enable long-term } \\
\text { development towards these objectives. } \\
\text { Minority shareholder in other users have the possibility on different levels to be involved } \\
\text { in the strategic and current discussions, to give their opinion and highlight their interest as } \\
\text { users. }\end{array}$ \\
\hline Assessment & Partly Compliant \\
\hline Comments & $\begin{array}{l}\text { In } 1999 \text { the State has sold its } 50 \text { percent share in VPC under the condition that measures } \\
\text { will be taken to improve the safety within VPC and to reduce systemic risk. However, the } \\
\text { owners have till now not changed the design of the clearing and settlement and appear to } \\
\text { be reluctant to do so due to the involved investment costs and the possible consequences it } \\
\text { might have in the market for custody services in which they play a major role. This calls } \\
\text { into question the ability of VPC to manage its own governance conflicts of interest and to } \\
\text { taken into account the public interest aspects as they have been formulated in VPCs } \\
\text { overall objectives. In the oversight/supervision should be given more attention to the } \\
\text { public interest aspects of VPC's operation and the reduction of systemic risks in order to } \\
\text { re-find a good balance between profitability, efficiency and safety. }\end{array}$ \\
\hline \multicolumn{2}{|c|}{$\begin{array}{l}\text { Recommendation 14-CSDs and CCPs should have objective and publicly disclosed criteria for participation } \\
\text { that permit fair and open access. }\end{array}$} \\
\hline Description & $\begin{array}{l}\text { VPC has different requirements for accountholder, nominees, clearing members and } \\
\text { settlement banks. However there are no access criteria for indirect participants although } \\
\text { they represent risks to the clearing. } \\
\text { In addition to capital requirements, there are checks as to whether the applicant has } \\
\text { sufficient knowledge of procedures, communication standards etc and whether the } \\
\text { applicant's operational and communicational systems are up to standard and form no } \\
\text { threat to the VPC system. } \\
\text { VPC rules and regulations contain explicit exit rules. } \\
\text { The criteria for access and the exit rules are the same for Swedish as for foreign } \\
\text { participants. However, for foreign customers a legal opinion is required to check the legal } \\
\text { status and the validity of VPC rules and relevant Swedish laws in the applicants home } \\
\text { country. }\end{array}$ \\
\hline Assessment & Partly compliant \\
\hline Comments & $\begin{array}{l}\text { The rules and regulations and the capital requirements are not transparent. It is difficult to } \\
\text { detect how they are related to risk and responsibility (for instance a differentiation } \\
\text { between clearing members that clear only on their own behalf and clearing members that } \\
\text { also clear and settle for other market participants and between clearing members and } \\
\text { clearing member/payment banks). The reasoning for the lack of criteria for indirect }\end{array}$ \\
\hline
\end{tabular}


participants is unclear. This made the access criteria in transparent and increases the risks in the system.

Recommendation 15-While maintaining safe and secure operations, securities settlement systems should be cost-effective in meeting the requirements of the users.

\begin{tabular}{|l|l|}
\hline Description & $\begin{array}{l}\text { The system is efficient and cost recovering. VPC monitors its charges against those of } \\
\text { other CSDs in Europe. A yearly survey among users will be introduced to get better } \\
\text { understanding of client's satisfaction. }\end{array}$ \\
\hline Assessment & $\begin{array}{l}\text { Compliant } \\
\text { Comments }\end{array}$ \\
\hline
\end{tabular}

Recommendation 16-Securities settlement systems should use or accommodate the relevant international communication procedures and standards in order to facilitate efficient settlement of cross-border transactions.

\begin{tabular}{l|l} 
Description & The normal communication is based on a proprietary system with a specific domestic
\end{tabular} standard. However, it is also possible to communicate with VPC via SWIFT and using SWIFT standard message types. In cross border communication the Swift standard message types are used.

Assessment Compliant

Comments None

Recommendation 17-CSDs and CCPs should provide market participants with sufficient information for them to identify and evaluate accurately the risks and costs associated with using the CSD or CCP services.

\begin{tabular}{l|l} 
Description & VPC has published a disclosure framework. This disclosure framework is based on several
\end{tabular} questionnaires, such as the Disclosure framework for securities settlement systems of the CPSS/IOSCO, the Depository questionnaire of the Associations of Global Custodians and the ISSA 2000 recommendation. The disclosure framework is presently under review. The IMF-mission has received a draft version of it, dated October 2001.

\begin{tabular}{l|l} 
Assessment & Partly compliant
\end{tabular}

\begin{tabular}{l|l} 
Comments & The disclosure framework does not provide market participants with sufficient
\end{tabular} information on the risks in the VPC netting schedules and should explain these risks more explicitly.

Recommendation 18-Securities settlement systems should be subject to transparent and effective regulation and oversight. Central banks and securities regulators should cooperate with each other and with other relevant authorities.

\begin{tabular}{l|l} 
Description & Securities settlement systems are under the supervision of the FI and under the oversight
\end{tabular} of the Riksbank. At present the organization of FI is in a transitionally period with the intent of focusing supervision on market places and market service providers. New supervisory methods (among other things) are being developed. This is the task of a separate project group. Within the Riksbank the financial infrastructure division of the Financial stability department is charged with the oversight of VPC.

Assessment Partly compliant

Comments

Supervision of the VPC is underdeveloped. There are no on-site inspections and no regular reporting of risk assessment to the regulatory authority. The FI appears to lack the necessary skill to understand the broad range of risks in the complex clearing and settlement systems at VPC and Stockholmbörsen. The legal framework for supervision make it difficult to taken into account the aspect of financial stability and the public interest in a safe and sound system. Till now there has been no risk-based approach and the legal risk, risk management policy and operational risk in the clearing and settlement have received the necessary attention. Especially in a rapidly changing environment with cross-border links and possible cross- border mergers this is a major vulnerability.

The Riksbank is more aware of the systemic risk aspect but lacks the necessary legal 


\begin{tabular}{|l|l|}
\hline $\begin{array}{l}\text { power to persuade VPC to change the risk management design. The Riksbank can and has } \\
\text { only used moral suasion to improve the system. This forms a major weakness for the } \\
\text { oversight role of the Riksbank. }\end{array}$ \\
$\begin{array}{l}\text { The overlapping responsibilities make the oversight structure in transparent. To solve the } \\
\text { aforementioned weaknesses in the regulatory framework, it is recommended that }\end{array}$ \\
$\begin{array}{l}\text { The regulatory powers of the Riksbank in the field of oversight of payment systems and } \\
\text { securities settlement systems should be reinstated in the Sveriges Riksbank Act. }\end{array}$ \\
$\begin{array}{l}\text { An explicit regulatory framework should be developed by FI and the Riksbank, which } \\
\text { should taken into account the existing legal requirements for clearing organizations, the } \\
\text { financial stability aspects and the international codes and standards. This should include a } \\
\text { fit and proper test for the management, the information requirements and the involvement } \\
\text { of the overseer in crisis situations. This regulatory framework should be published. An } \\
\text { example of such a framework has been handed out during the stay of the mission in }\end{array}$ \\
$\begin{array}{l}\text { Stockholm. } \\
\text { Recommendation 19-CSDs that establish links to settle cross-border trades should design and operate such } \\
\text { links to reduce effectively the risks associated with cross-border settlement. }\end{array}$ \\
\hline $\begin{array}{l}\text { Description } \\
\text { VPC only uses free of payment links. The links are till now not heavily used and do no } \\
\text { contain substantial risks. }\end{array}$ \\
\hline Compliant \\
\hline Comments
\end{tabular}

Table 12. Summary observance of CPSS/IOSCO Recommendation for securities settlement systems —Name of SIPS

\begin{tabular}{|l|l|l|}
\hline \multirow{2}{*}{ Assessment grade } & \multicolumn{2}{|c|}{ Recommendations grouped by assessment grade } \\
\cline { 2 - 3 } & \multicolumn{1}{|c|}{ Count } & \multicolumn{1}{c|}{ List } \\
\hline COMPLIANT & 12 & Rec. $3,4,5,6,7,8,10,11,12,15,16$ and 19 \\
\hline Broadly compliant & 1 & Rec. 1 \\
\hline Partly compliant & 5 & Rec. $2,13,14,17$ and 18 \\
\hline Non compliant & 1 & Rec. 9 \\
\hline Not applicable & 0 & \\
\hline
\end{tabular}




\section{B. Recommended actions and authorities' response to the assessment}

Table 13. Recommended actions to improve observance of CPSS/IOSCO Recommendations for securities settlement systems - Name of SIPS

\begin{tabular}{|c|c|}
\hline Reference recommendation & Recommended action \\
\hline $\begin{array}{l}\text { Legal foundation } \\
\text { Rec. } 1\end{array}$ & $\begin{array}{l}\text { Scrutinize the legal framework to make it more transparent e, } \\
\text { to support existing market practices and to strengthen the } \\
\text { position of the custody sector in the financial European } \\
\text { market. (government) }\end{array}$ \\
\hline $\begin{array}{l}\text { Custody } \\
\text { Rec. } 6 \text { and } 12\end{array}$ & ------ \\
\hline Understanding and management of risks & \\
\hline Rec. $4,5,9,10,17$ and 19 & $\begin{array}{l}\text { Provide regulators with insight in the risks in the VPC netting } \\
\text { schemes (VPC) } \\
\text { Implement adequate risk management measures in both } \\
\text { netting schemes of VPC (VPC/regulators) } \\
\text { Reduce liquidity risk on the securities sides by introducing } \\
\text { transparent responsibilities for clearing members who clear } \\
\text { and settle for indirect participants (VPC) } \\
\text { Make the risk in the netting schemes transparent for users by } \\
\text { adapting the disclosure framework (VPC) }\end{array}$ \\
\hline $\begin{array}{l}\text { Settlement } \\
\text { Rec. } 2,3,7 \text { and } 8\end{array}$ & ----- \\
\hline $\begin{array}{l}\text { Security and operational reliability, and } \\
\text { contingency arrangements } \\
\text { Rec. } 11 \text { and } 16\end{array}$ & ------ \\
\hline $\begin{array}{l}\text { Efficiency and practicality of the system } \\
\text { Rec. } 15\end{array}$ & ------ \\
\hline Criteria for participation & \\
\hline Rec. 14 & $\begin{array}{l}\text { Reconsider the participation of the so-called indirect } \\
\text { Participants in the Money Market Clearing (VPC/regulators) }\end{array}$ \\
\hline $\begin{array}{l}\text { Governance of the payment system } \\
\text { Rec. } 13\end{array}$ & $\begin{array}{l}\text { Give more attention in the oversight/supervision to the public } \\
\text { objectives of VPC (regulators) }\end{array}$ \\
\hline Regulation and oversight & \\
\hline Rec. 18 & $\begin{array}{l}\text { Strengthen the legal powers of the Riksbank with respect to } \\
\text { oversight (parliament) } \\
\text { Develop an explicit framework for oversight/supervision of } \\
\text { payment systems and securities settlement systems that takes } \\
\text { in account the stability of the financial sector } \\
\text { (Finansinspectionen/Riksbank) }\end{array}$ \\
\hline
\end{tabular}


Develop a framework for cooperation between Finansinspectionen and the Riksbank with respect to the oversight of payment systems and securities settlement systems (Finansinspectionen/Riksbank)

\section{Authorities' Response}

96. Efficiency and practicality of the system (CP VIII). The Riksbank is of the opinion, that in a small country like Sweden with highly concentrated banking sector it is not possible to charge enough to cover the cost, especially considering the cost to keep the security level high. The payment sector contains large fixed costs and it is a service that includes elements of a collective good, which also has network externalities. The burden-sharing between the participants and the society at large needs to be looked at with this in mind.

97. Oversight and Central Banks responsibilities in applying the core principles. Both the Riksbank and Finansinspectionen share the view of the assessment that the cooperative arrangement between the Riksbank and Finansinspectionen for the oversight of payment systems and securities settlement systems needs to be formalized and made more transparent. Both organizations have agreed to develop and publish a MOU about oversight-methodology on payment and securities settlement systems, the responsibility of the respective institutions and the cooperation arrangements between them. Finansinspectionen will introduce a new supervisory approach for the oversight of payment and securities settlement systems, especially, with respect to VPC and Stockholmbörsen. And in 2002 the rules and regulations of VPC have been changed in such a way, that, as per October the first, indirect participants will no longer be allowed in the systems and the clearing member who has them as customer will be fully responsible for their obligations. Also a new clearing and settlement model will be introduced to eliminate the existing unwinding procedure. 